\title{
A D1 PROTEIN MUTÁCIÓ HATÁSA A KETTES FOTOKÉMIAI RENDSZER ENERGIA- HASZNOSÍTÁSÁRA ELTÉRŐ VÍZELLÁTÁSÚ NÖVÉNYEKBEN
}

Ph.D. értekezés

Bajkán Szilvia

Témavezető: Prof. Dr. Lehoczki Endre

\begin{abstract}
Biológia doktori iskola
Szegedi Tudományegyetem, Természettudományi és Informatikai Kar Növénybiológiai Tanszék
\end{abstract}




\section{TARTALOMJEGYZÉK}

Rövidítések és jelölések jegyzéke

1. Bevezetés

$\begin{array}{lr}\text { 2. Irodalmi áttekintés } & 8\end{array}$

2.1. Az elnyelt fényenergia sorsa a fotoszintézis során $\quad 8$

2.1.1. A fény fotokémiai hasznosulása 8

2.1.2. A többlet elnyelt fényenergia sorsa és káros hatásai a növények leveleiben 11

2.1.3. A fény káros hatásaival szemben kialakult fotoprotektív mechanizmusok 12

2.1.4. A nem-fotokémiai kioltás és lokalizációja magasabbrendü növényekben 13

2.1.5. A xantofillok szerepe a hödisszipáció folyamatában, a xantofill ciklus-függö és

független nem-fotokémiai kioltás 17

2.1.6. A PsbS fehérje szerepe a hödisszipáció folyamatában 20

2.2. A vízdeficit hatása a magasabbrendü növények fotoszintézisére 22

2.2.1. A vizhiány fokozatainak jellemzése, a sztomatikus és a nem-sztomatikus limitáció értelmezése $\quad 22$

2.2.2. A védekezö/szabályozó folyamatok szerepe a vizhiány kivédésében 25

2.2.3. Stratégiák a vizhiány tolerálására

2.3. Az atrazin rezisztencia 28

3. Célkitüzés 32

4. Anyag és módszer 33

4.1. A vizsgált növényi anyag 33

4.2. Növénynevelés, vízmegvonás 33

4.3. Reciprok keresztezések kivitelezése, genetikai analízis 34

4.4. A növény vízellátásának vizsgálata 35

4.4.1. Sztómasürüség vizsgálata 35 
4.4.3. A levélszövetek átlagos vízpotenciáljának mérése 36

4.4.4. Sztóma konduktancia mérése 36

4.5. Elektron mikroszkópia $\quad 37$

4.6. Gázcseremérések 37

4.6.1. $\mathrm{CO}_{2}$ asszimilációs ráta meghatározása a fényintenzitás függvényében 37

4.6.2. $\mathrm{CO}_{2}$ asszimilációs ráta meghatározása az intercelluláris $\mathrm{CO}_{2}$ koncentráció

függvényében 38

4.7. Klorofill fluoreszcencia mérések 38

4.7.1. Gyors klorofill a fluoreszcencia indukció (OJIP görbe) mérése 38

4.7.2. Modulációs klorofill a fluoreszcencia mérés, fotoprotektív folyamatok vizsgálata

4.7.3. A PSII-ben elnyelt fényenergia megoszlásának vizsgálata 42

4.8. Fotoszintetikus pigmenttartalom meghatározás 43

4.9. DNS izolálás és PCR amplifikáció, PsbS és PsbA (D1) fehérjéket kódoló DNS

szakaszok szekvenálása $\quad 44$

4.10. Immunoblot analízis $\quad 45$

4.11. Statisztikai analízis $\quad 45$

5. Eredmények 4

5.1. Az elnyelt fényenergia hasznosításának összehasonlító vizsgálata a $S$. nigrum kétféle biotípusában és a különböző növénynemzedékekben 46

5.1.1. A S. nigrum biotípusok és vonalak fotoszintetikus jellemzése 46

5.1.2. Az NPQ és az elnyelt fényenergia allokációja a PSII-ben 52

5.1.3. A S. nigrum vonalak sejtmagi hibrid státuszának igazolása 58

5.2. A vízdeficit hatásának összehasonlító vizsgálata $S$. nigrum kétféle biotípusában és a különböző növénynemzedékekben 61

5.2.1. A vízdeficit hatása a növények vizállapotára és a gázcseréjére 61

5.2.2. A vizdeficit hatása az elnyelt fényenergia fotokémiai hasznositására 70 
5.3. Egyes nukleáris öröklődésű faktorok hatása a fotoszintetikus fényenergia hasznosításra

6. Eredmények megvitatása

7. Összefoglalás

8. Summary

9. Irodalomjegyzék

10. Függelék

115

11. Publikációs lista 


\title{
RÖVIDÍTÉSEK ÉS JELÖLÉSEK JEGYZÉKE
}


reakciócentrum klorofill $a$ a kettes fotokémiai rendszerben

$\mathrm{Q}_{\mathrm{A}}$ kettes fotokémiai rendszer elsődleges kinon elektron akceptora

$\mathrm{Q}_{\mathrm{B}}$

kettes fotokémiai rendszer másodlagos kinon elektron akceptora

$\mathrm{qE}$

a nem-fotokémiai kioltás energia $(\Delta \mathrm{pH})$-függő komponense

qI

$\mathrm{qT}$

a nem-fotokémiai kioltás lassan relaxálódó komponense

$\mathrm{qP}$

"state" átmenet

$1-\mathrm{qP}$

fotokémiai kioltási koefficiens

$\mathrm{RC}$

a kettes fotokémiai rendszerre ható gerjsztési nyomás

RH1

reakciócentrum

RH2

rehidratált állapot a DH1 szakaszból 24 óra után (rehydration state1)

rehidratált állapot a DH2 szakaszból 24 óra után (rehydration state2)

RH3

rehidratált állapot a DH3 szakaszból 24 óra után (rehydration state3)

Rubisco

ribulóz 1,5-biszfoszfát karboxiláz oxigenáz

RuBP

ribulóz 1,5-biszfoszfát

RWC

relatív víztartalom (Relative Water Content)

TL

termolumineszcencia

Vio

violaxantin

Zea

zeaxantin

$\varepsilon$

a Rubisco enzim aktivitása és/vagy extrahálható mennyisége (karboxilációs hatékonyság), mely az $\mathrm{A} / \mathrm{C}_{\mathrm{i}}$ görbe lineáris szakaszának kezdeti meredeksége

$\phi$ látszólagos kvantumhatásfok: $\mathrm{CO}_{2}$ asszimiláció aktinikus fényre adott válaszgörbéjének kezdeti meredeksége, mely a beeső fotonáram-sürüségen alapul

fényben disszipálódott hőenergia frakciója

$\Phi_{\mathrm{DD}}$

sötétben történő energiaveszteség

$\Phi_{\mathrm{E}}$

$\Phi_{\mathrm{NO}}$

többlet energia frakció

$\Phi_{\mathrm{NPQ}}$

nem-regulált (konstitutív) energia disszipáció hatásfoka

$\Phi_{\text {PSII }}$

regulált termális energia disszipáció hatásfoka

kettes fotokémiai rendszer fotokémiájának hatásfoka

$\Psi[\mathrm{MPa}]$ 


\section{BEVEZETÉS}

A növények a napok többségében ki vannak téve a fényintenzitás dinamikus változásának, és gyakran több fényenergiát nyelnek el, mint amennyit hasznosítani tudnak a fotoszintézis során. Az elnyelt többlet gerjesztési energia károsíthatja a fotoszintetikus apparátust (szingulett oxigén, reaktív oxigén fajták képződése által). Ezért a fény fotokémiai hasznosulási folyamata mellett olyan fotoprotektív mechanizmusoknak is ki kellett alakulniuk, amelyek az elnyelt energiatöbbletet veszélytelen módon elvezetik a rendszerböl. Egy ilyen folyamat a nem-radiatív energia disszipáció (hődisszipáció). Ezt a mechanizmust a klorofill fluoreszcencia fényfüggő, nem-fotokémiai kioltásaként (NPQ) definiáljuk. Az NPQ legnagyobb komponense a gyorsan relaxálódó, $\Delta \mathrm{pH}$-függő $\mathrm{qE}$ komponens. Az NPQ mechanizmusa csak részben ismert, de kialakulásának feltételei az tilakoid lumen alacsony kémhatása, de-epoxidált xantofillok képződése, PsbS és fénybegyüjtő komplex (LHC) fehérjék protonációja.

Az ez idáig vizsgált atrazin-rezisztens (AR) gyomnövényekben (Chenopodium album, Epilobium adenocaulon, Erigeron canadensis, Senecio vulgaris, Solanum nigrum) kimutatták a csökkent mértékủ NPQ kapacitást, ezen belül a csökkent qE komponenst (Váradi et al., 2003). Eddigi ismereteink szerint az NPQ kialakulását nukleárisan kódolt faktorok határozzák meg, habár a kettes fotokémiai rendszer (PSII) reakciócentrum D1 fehérjét kódoló $p s b A$ gén amely a rezisztens növényekben a mutációt hordozza - a kloroplasztisz genom része. Ezért nem világos, hogy a $\mathrm{D} 1$ fehérje milyen hatással van az antennában végbemenő hődisszipáció kialakulására.

Reciprok keresztezéseket végeztünk a Solanum nigrum vad-típusú és atrazin-rezisztens biotípusai között, és az ebből származó hibridekkel (F1, F2 egészen az F6-ig) vizsgálatokat folytattunk annak érdekében, hogy közelebb jussunk annak a kérdésnek a megválaszolásához, milyen kapcsolat van a D1 protein mutáció és a PSII antennájában elnyelt fényenergia allokációja között: ezen belül tanulmányoztuk a $\mathrm{qE}$ komponens és az allokációs mintázat öröklődését.

Ismeretes az atrazin-rezisztens növények eltérö hömérséklet-érzékenysége és adaptációs képessége (Ducruet \& Lemoine, 1985), illetve fokozott fényérzékenységükről egyaránt beszámoltak (Hart \& Stemler, 1990). Napjainkban a vízhiány (szárazság) az egyik 
legfontosabb környezeti tényezö, amely a növény növekedését/produktivitását limitálja. Természetes körülmények között a vízdeficit gyakran együtt jár a magas hömérséklettel és/vagy a magas fotonáram-sürüséggel (fénygátlás). Tudomásunk szerint a vízdeficit (szárazság) fotoszintézisre gyakorolt hatásait ez idáig nem vizsgálták még D1 protein mutáns növényekben. Ezért a dolgozatom másik fő témájának a vízdeficit hatásának tanulmányozását választottam a Solanum nigrum gyomnövény kétféle biotíopusában, annak a kérdésnek a megválaszolására, vajon a vízdeficit befolyásolja-e a D1 protein mutáns növények fitneszét. 


\section{IRODALMI ÁTTEKINTÉS}

\subsection{Az elnyelt fényenergia sorsa a fotoszintézis során}

\subsubsection{A fény fotokémiai hasznosulása}

A fotoszintézis folyamata a fény elnyelésével veszi kezdetét, amely különböző pigment molekulák segítségével valósul meg. Növényekben az elsődleges fényelnyelő pigment a klorofill $a(\mathrm{Chl} a)$. A fény elnyelése által a gerjesztett Chl molekula négy lehetséges úton veszítheti el a gerjesztési energiáját: alapállapotba kerülhet fotonkibocsátással (fluoreszcencia); hő formájában; részt vehet energiatranszferben, amikor is átadhatja az energiáját egy másik molekulának; vagy a gerjesztési energia kémiai reakciót eredményez (1. ábra).

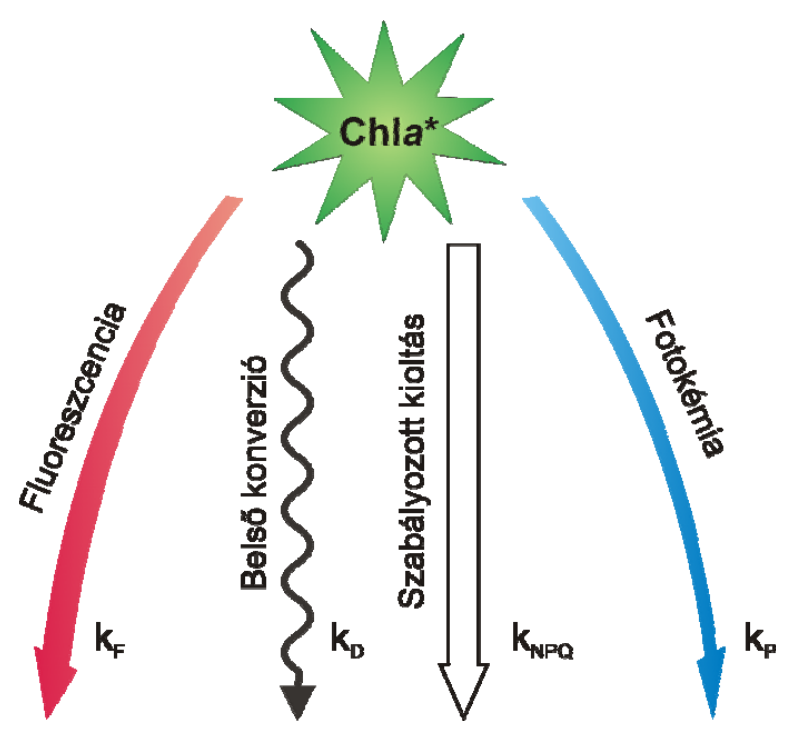

1. ábra Egymással versengö folyamatok a PSII-ben, amelynek során egy gerjesztett állapotban lévö klorofill molekula visszatérhet az alapállapotba. 
A levelek által elnyelt fényenergia eloszlásának kvantifikálása a fotoszintézis kutatás egyik fontos aspektusává vált. A különféle folyamatok, pl. fotoszintézis, fotorespiráció, víz-víz és xantofill ciklus, melyek hozzájárulnak a fotoszintetikus apparátus fotoprotekciójához, két kategóriába sorolhatók: a fotokémia és a termális disszipáció folyamatai. Miután ezek kompetitívek, a Chl fluoreszcencia hatásfokának változása alapján következtethetünk az említett folyamatok hatásfokában bekövetkező változásokra (Schreiber et al., 1994), melyet a PSII (2. ábra) fotokémiai hatásfokával ( $\left.\Phi_{\mathrm{PSII}}\right)$ és az NPQ paraméterrel jellemeznek (Genty et al., 1989; Bilger et al., 1995).

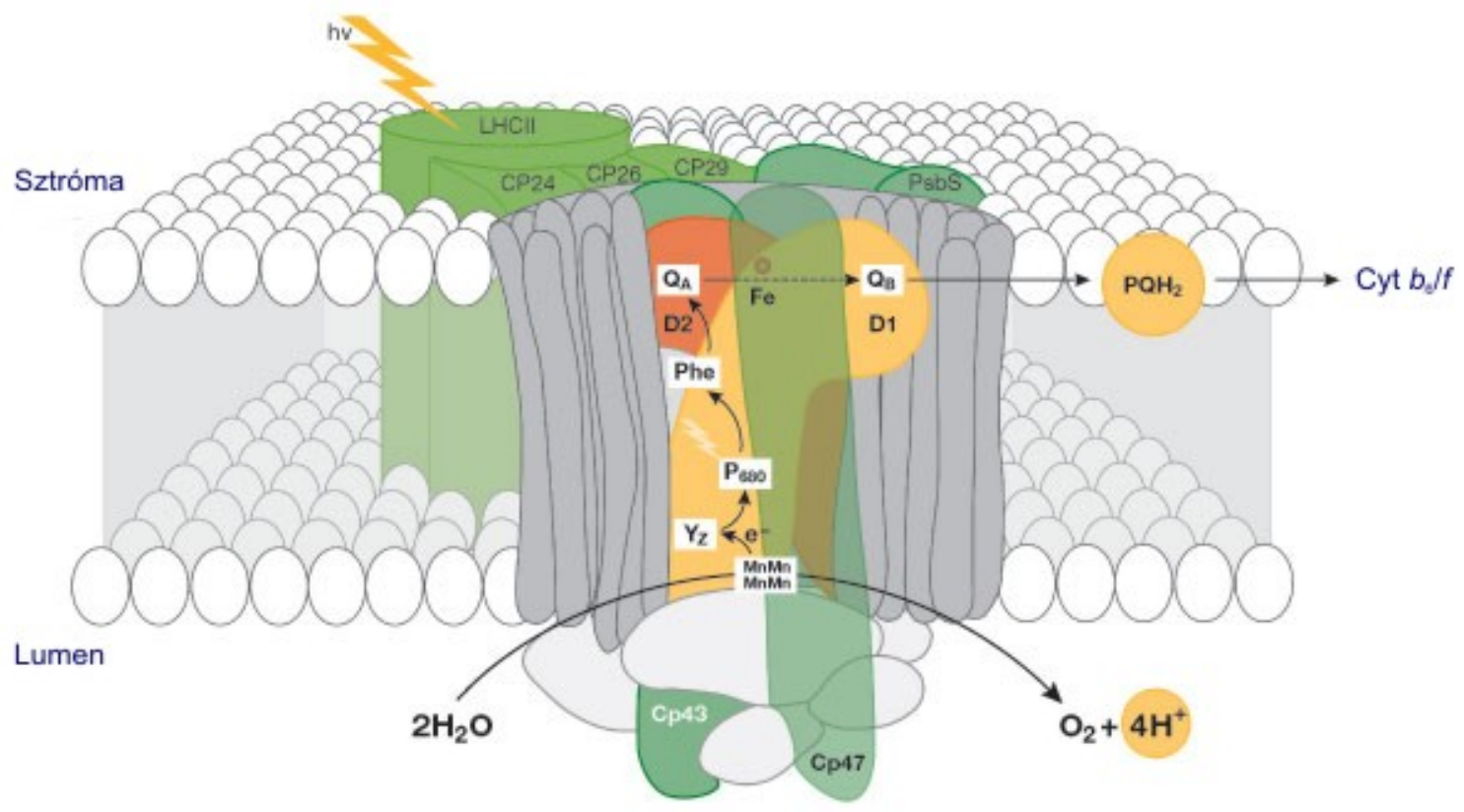

2. ábra A PSII föbb alkotórészei, a D1/D2 reakciócentrum proteinek az elektrontranszportlánc komponenseivel és a fénybegyüjtö antenna komplexek a tilakoid membránba ágyazódva J. Nield (Imperial College London, UK) nyomán.

A fotoszintézis során a növények, algák és egyes baktériumok a Napból származó fényenergiát átalakítják és azt energiában gazdag, szerves vegyületekben tárolják. A fotoszintézis folyamata két szakaszra bontható: az ún. fényszakaszban a lineáris 
elektrontranszport során keletkezik az adenozin-trifoszfát (ATP) és a redukált nikotinamidadenin-dinukleotid-foszfát (NADPH), mely molekulák a sötétben is lejátszódó ún. sötétszakaszban a széndioxid szénhidrátokká történő biokémiai átalakításának feltételei. A NADPH legfőbb fogyasztója a $\mathrm{CO}_{2}$ asszimiláció, de ezen kívül a szulfát és a nitrát redukció folyamataiban is felhasználásra kerül.

Léteznek nem asszimilációt előidéző elektrontranszport folyamatok is, melyek lejátszódásának valószínűsége megnövekedhet bizonyos körülméyek között. Például a szárazság hatása napjainkban egy igen fontos környezeti tényezővé vált, melynek következtében a fokozódó sztómazáródás csökkenti a kloroplasztiszok $\mathrm{CO}_{2}$ ellátását, és az oxigén felé irányuló nem-asszimilációs elektrontranszport (fotorespiráció, Mehler-reakció) valószínűsége megnövekszik. Ezek a mechanizmusok a többletenergiának egy biztonságos módon történő disszipációját teszik lehetővé (Osmond \& Grace, 1995). A fotorespiráció (glikolát-ciklus) (Cornic et al., 1989; Renou et al., 1990; Tourneux \& Peltier, 1995; Flexas \& Medrano, 2002), mely folyamat a $C_{3}$ típusú növényekre jellemző, a fotoszintézis egy lehetséges alternatív útjaként jelentős lineáris elektrontranszportot képes fenntartani, így nagymértékben biztosíthatja a többlet gerjesztési energia elvezetését. Az oxigén egyes fotokémiai rendszer (PSI) általi fotoredukciója (Mehler-reakció, Asada, 1999) úgy tủnik, csak elenyésző mértékben járul hozzá az energia-disszipáció folyamatához. Haupt-Herting és Fock (2002) fejtegetései alapján a Mehler-reakció folyamán bekövetkező fotoredukció egy nemenzimatikus folyamat, mely függ az elektrontranszport sebességétől, és tényleges hozzájárulása a gerjesztési energia felhasználásához valószínüleg abban az esetben csökken, amennyiben pl. szárazság hatására csökken az elektrontranszport sebessége.

A PSII-n belüli ún. ciklikus elektrontranszport esetében is felvetődött az a lehetőség, hogy hozzájárulhat a többlet gerjesztési energia eltávolításához (Chow, 1994; Whitmarsh et al., 1994), jóllehet in vivo létezése meggyőző módon nem bizonyított. Ebben a folyamatban valószínűleg részt vesz a $\mathrm{D} 1 / \mathrm{D} 2$ reakciócentrumhoz $(\mathrm{RC})$ szorosan kötődő citokróm $b_{559}$ heterodimer fehérje, ami feltevések szerint aktuális redoxpotenciáljától függően a RC Chl $\left(\mathrm{P} 680^{+}\right)$donoraként vagy a feofitin akceptoraként funkcionálhat, ekképpen védheti a PSII-t a fénykárosodástól (Whitmarsh et al., 1994). A PSI körüli ciklikus elektrontranszport során a redukált ferredoxin $(\mathrm{Fd})$ molekula elektront ad át a citokróm (Cyt) $b_{\sigma} / f$ komplex kitüntetett helyén kötődő kinon vagy szemikinon molekulának, melynek eredményeként a Cyt $b_{\sigma} / f$ részt 
vesz a tilakoid membránon keresztüli $\Delta \mathrm{pH}$ létrehozásában és fenntartásában. $\mathrm{E}$ mechanizmusról ugyancsak feltételezik, hogy fontos szerepet tölt be a fotoprotekcióban (Heber \& Walker, 1992). Minthogy a ciklikus elektrontranszport során NADPH nem keletkezik, a tilakoid membránon keresztüli proton gradiens másfelől ATP szintézist indukál, ez a folyamat ATP/NADPH arány regulációjára szolgál.

\subsubsection{A többlet elnyelt fényenergia sorsa és káros hatásai a növények leveleiben}

A növények a természetben gyakorta ki vannak téve a fényintenzitás rapszodikus változásának, így olykor több fényenergiát nyelnek el, mint amennyit hasznosítani képesek fotoszintézisük során. Az elnyelt fényenergia mennyiségének növekedésével a fotoszintetikus teljesítmény - amelyet a genetikai adottságon túl az adott élöhelyen a növényt érő fényintenzitás-maximumok határoznak meg - egy telítési fázisig képes növekedni, míg a beeső fény elnyelése továbbra is lineárisan növekszik. A leveleket érő napsugárzás kb. $80 \%$-át nyelik el a fotoszintetikus pigment molekulák (Björkman \& Demmig, 1987), míg az energia kisebb hányada reflektálódik a levelek felszínéről, vagy áteresztik azt a levél szövetei. Az abszorbció révén a pigment molekulákban kialakult gerjesztett állapot energiája a töltésszétválasztást követően fotokémiai reakciót eredményezhet. A fotoszintézis során nem hasznosuló többlet energia frakció a növényekben kialakult fotoprotektív mechanizmusok müködése során eliminálódik. A gerjesztési energiatöbblet ezek után is megmaradó része krónikus károsodást okozhat a fotoszintetikus apparátusban, amihez az is hozzájárul, hogy a PSII müködése során molekuláris oxigén fejlödik, ami a megnövekedett mennyiségü, hosszabb élettartamú triplett gerjesztett állapotú Chla molekulákkal ( $\left.{ }^{3} \mathrm{Chl} a^{*}\right)$ kölcsönhatásba lépve szingulett oxigén képződést eredményez. Kimutatták ezenkívül más reaktív oxigén formák, mint például a szuperoxid-gyökanion, hidroxil-gyök, hidrogénperoxid, illetve egyéb szerves gyökök képződését is. Mindezek a tilakoid membrán irreverzibilis, oxidatív károsodásához (fénygátlás) vezethetnek (Hurry et al., 1996), valamint pigment-, ill. fehérjedegradációt okozhatnak (Andersson \& Barber, 1996; Aro et al., 1993). Hatástalanításuk érdekében számos antioxidáns molekula és enzimrendszer müködik a kloroplasztiszban, amelyek képesek befogni a fotoszintézis által szükségszerüen termelt reaktív oxigén formákat (Asada, 1994; Foyer et al., 1994; Polle, 1997). 


\subsubsection{A fény káros hatásaival szemben kialakult fotoprotektiv mechanizmusok}

A természetben a növényeknek alkalmazkodniuk kell a fény intenzitásának és spektrális tulajdonságainak gyakori változásához. Az evolúció során többszintü adaptációs hálózat alakult ki, amelynek segítségével a fotoszintetizáló organizmusok megbirkóznak a fényviszonyok fluktuációjával. Ezek két csoportba sorolhatók: $(i)$ a fényelnyelés szabályozásával és (ii) a befogott fényenergia sorsával kapcsolatos adaptációs mechanizmusok. A teljes egyed szintjén megvalósuló adaptáció például a levél-orientáció szabályozása (Björkman \& Powles, 1987). Ez néhány, árnyék típusú, alacsony fotoszintetikus kapacitással bíró növény esetében igen hatékonyan müködik, melyek egyszer-egyszer ki vannak téve a közvetlen napsugárzásnak. A sivatagi növények egy része szervetlen anyagokat (pl. sókristályok) halmoz fel a levélfelszínen, vagy levegővel töltött szőröket fejleszt, hogy növelje a levél reflexióját, ezáltal csökkentve az elnyelt fény mennyiségét. Sejtszinten a fényelnyelést a kloroplasztiszok mozgása szabályozhatja (Chow et al., 1988), mely relatíve gyorsan, percek alatt valósul meg, de csupán kb. 10-20\%-kal csökkenti azt (Brugnoli \& Björkman, 1992).

A molekuláris szintü adaptációs mechanizmusok gyakran összetett, fényfüggő génexpresszió szabályozás eredményei, melyek transzkripciós, transzlációs és poszttranszlációs szinteken valósulnak meg (Kloppstech, 1997). E folyamatok napokat, heteket vehetnek igénybe és a tilakoid membrán szintjén jelentős összetételbeli és szerkezeti változásokat foglalnak magukban. Egy ezek közül a PSI és PSII antenna méreteinek fény általi módosulása, mely egy igen konzervált jelenség (Anderson et al., 1995). Magas fényintenzitás mellett nőtt növényekben az antennaméret mindig kisebb, mint az árnyéknövényekben. A fényviszonyoktól függően megváltozik az egy RC-ra jutó, külső fénybegyüjtő komplexek (LHC) mennyisége, ezáltal megváltozik az adott fotokémiai rendszer abszorpciós hatáskeresztmetszete. Egy másik, hosszútávú akklimatizációs módosulás a PSI és PSII arányának változása, és a PSII RC-ok szubpopulációjának inaktiválódása (Anderson et al., 1988; Melis, 1991). Például az erdő lombkoronája által megszürt fényben (több távoli vörös fény) nőtt árnyéknövények nagyobb PSII/PSI aránnyal bírnak, ezzel kompenzálva a vörös fény kisebb mennyiségét, mely a PSII gerjesztéséhez szükséges (Anderson \& Osmond, 2001). 
A rövidtávú adaptációk, melyeket génexpresszió változások nem kísérnek, másodperceken és perceken belül mennek végbe, és semlegesítik a fényviszonyok gyors változásainak hatásait, úgymint a diurnális változások a fény mennyiségében és minőségében, az időjárás által előidézett pillanatnyi fluktuációk, és a lombozat általi fényszürés (Anderson \& Osmond, 2001). A legjobban dokumentált adaptáció, amely "state” átmenetként (qT) ismert (Bonaventura \& Mayers, 1969), perces időskálán mozog, müködése alacsony/közepes fényintenzitások mellett hatékony, pl. akkor, amikor a fényintenzitás nem limitálja a fotoszintézist (Horton \& Hague, 1988). A plasztokinon (PQ) készlet (Horton, 1981; Allen et al., 1981) és a Cyt $b$ (Gal et al., 1987) redoxállapotai mintegy szenzorként/jelátalakítóként müködnek és egy protein kináz aktivációjában vesznek részt (Bennett, 1977; 1979). A PSIInek a PSI-hez képest mutatkozó viszonylagos túlgerjesztése során ez a kináz néhány LHCII komplexet foszforiál (ún. mobil LHCII) (Mullet, 1983), melyek ledisszociálnak a PSII-ről, csökkentve az antenna tényleges méretét, és az elnyelt energiát a PSI felé továbbítják.

A PSII hatékonyságának szabályozása (Weiss \& Berry, 1987; Genty et al., 1989) reverzibilisen, nem-lineárisan függ a fényintenzitástól, holott a nyitott RC-ok száma és a PSII hatásfoka között lineáris összefüggést feltételeztek. A linearitástól való eltérés legésszerübb magyarázata az, hogy a PSII antennában megnyílik egy csatorna, mely a többlet gerjesztési energia disszipációját lehetővé teszi. Ez Chl fluoreszcencia mérésekkel, az ún. fluoreszcencia kioltás analízis módszerével nyomonkövethető, pl. pulzus amplitudó modulációs (PAM) technikával (Schreiber, 1986). Az analízis egyik paramétere, az NPQ, a többlet energia disszipációjának nagyságát méri a PSII-ben zárt RC-ok esetében. A PSII hatásfoka fordított lineáris összefüggést mutatott az NPQ-val (Genty et al., 1989). Eszerint a PSII hatásfokát egy nem-radiatív energia disszipáció, NPQ-alapú folyamat kontrollálhatja, melyet a tilakoid membránon keresztül felépülő proton gradiens $(\Delta \mathrm{pH})$ vált ki (Oxborough \& Horton, 1988).

\subsubsection{A nem-fotokémiai kioltás és lokalizációja magasabbrendü növényekben}

Többlet fényenergia elnyelése esetén a csökkent fotokémiai kioltás a szingulett gerjesztett Chla $\left({ }^{1} \mathrm{Chl} a^{*}\right)$ életidejének és a triplett $\mathrm{Chl} a\left({ }^{3} \mathrm{Chl} a^{*}\right)$ keletkezés valószínüségének megnövekedéséhez vezet a spinváltó átmenet során. $\mathrm{A}^{3} \mathrm{Chl} a^{*}$ reakcióba lép az alapállapotban triplett oxigénnel $\left({ }^{3} \mathrm{O}_{2}\right)$ és reaktív oxigén formákat hoz létre, amelyek elősegíthetik a 
fotoinhibíció és az oxidatív stressz kialakulását (Barber \& Andersson, 1992). E károsító folyamatok ellensúlyozására fotoprotekciós mechanizmusok inicializálódnak, melyek eliminálják a reaktív oxigén formákat (Asada, 1999) vagy a ${ }^{1} \mathrm{Chl} a{ }^{*}$ disszipációján keresztül megakadályozzák ezek létrejöttét (Niyogi, 2000; Külheim et al., 2002). Ez utóbbit a Chla fluoreszcencia fényfüggő, nem-fotokémiai kioltásaként definiáljuk.

Általában az NPQ-t technikailag három kompenensre osztják a relaxációs kinetikáikat alapul véve: a relaxáció gyors (qE), közepes (qT), és lassú (qI) fázisai szerint (Horton \& Hague, 1988), melyek az energiafüggő kioltásnak, a "state" átmenetnek, és a fotoinhibíciós kioltásnak tudhatók be (Quick \& Stitt, 1989). Az első komponens, a visszacsatolásos gerjesztési energia lecsengetés (qE) reverzibilis, gyorsan aktiválódik a növekvő fényintenzitással, és gyorsan, tíz perc, relaxálódik a sötétben, amely mind közül a legjobban tanulmányozott folyamat. E folyamat lehetővé teszi a többlet gerjesztési energia hőként való disszipációját, ezáltal védelmet nyújtva a fotoszintetikus pigmentek, fehérjék és lipidek fotooxidációja és károsodása ellen, mely folyamat különben a fotoszintézis fotoinhibícióját/fotoinaktivációját okozhatná, illetve, mely folyamat a növények produktivitására, fitneszére jelentős befolyással bír természetes körülmények között (Krivosheeva et al., 1996; Ögren \& Rosenqvist, 1992; Ögren \& Sjöström, 1990). A kioltás e típusa egy finoman szabályozott folyamat, amelyben a fö szabályozó tényezők a kloroplasztisz tilakoid membránon keresztül kiépülő proton gradiens $(\Delta \mathrm{pH})$ (Wraight \& Crofts, 1970; Briantais et al., 1979), a xantofill ciklus, azaz a violaxantin (Vio) konverziója anteraxantinná (Ant) és zeaxantinná (Zea) (Demmig et al., 1987; Demmig-Adams, 1990; Demmig-Adams \& Adams, 1992; Niyogi et al., 1997), és a PsbS fehérje, amely a két, lumen felőli protonálható csoportja (E122 és E226) révén érzékeli az alacsony lumenális pH-t (Funk et al., 1995; Li et al., 2000; 2004; Niyogi et al., 2005). Chlb illetve Lhc fehérje hiányos mutánsok, vagy olyanok, melyekben módosult a PSII antenna struktúra szerveződése, eröteljes NPQ csökkenést mutatnak, amely bizonyítja az antenna fehérjék szerepét az NPQ aktiválásában (Briantais, 1994; Kovács et al., 2006; de Bianchi et al., 2008).

Az NPQ tényleges molekuláris mechanizmusa nem ismert, jóllehet számos hipotézis és feltételezett kioltó (quencher) létezik: energia transzfer Chl-ról Zea-ra az LHCII-ben (Frank et al., 2000); elektrontranszfer egy karotinoidról Chl-ra létrehozván egy Zea-Chl vagy lutein (Lut)-Chl töltés transzfer állapotot (Holt et al., 2005; Avenson et al., 2009); direkt vagy 
indirekt kioltás a PsbS fehérje által (Li et al., 2000; Niyogi et al., 2005); energia transzfer Chlról Lut-re az LHCII-ben (Horton et al., 1991; Ruban et al., 2007) az LHCII aggregáció vagy konformáció változásához kapcsolódva; valamint az LHCII aggregációja által kialakult távoli vörös fényt kibocsátó kioltó Chl-Chl töltés transzfer állapot (Miloslavina et al., 2008). Egyesek feltételezik a PSII RC kioltás meglétét (Finazzi et al., 2004; Ivanov et al., 2008), amit a Zea-független kioltás egy további típusaként tartanak számon. Néhányan úgy vélik, hogy a Lut általi kioltás a Zea-függő kioltás kiegészítőjeként funkcionálhat (Niyogi et al., 2001; Li et al., 2009). Johnson és munkatársai (2009) munkája azt az elképzelést támogatja, hogy mind a Zea-független, mind a Zea-függő kioltás a PsbS-függő mechanizmusból ered, amelyet a Zea modulál (Crouchman et al., 2006).

Míg a gyorsan relaxálódó qE jól jellemzett, a lassabb qT és qI fázisok még mindig vitatottak, és gyanítják, hogy talán több, mint egy mechanizmus is hozzájárulhat a kialakulásukhoz. A qI-t hagyományosan a PSII fotoinhibíciójának tulajdonították (Somersalo \& Krause, 1988), mely összefüggésben van a fotokémiai rendszer koordinált degradációjával és helyreállításával (Powles \& Björkman, 1982; Kyle, 1987; Krause, 1988; Aro et al., 1993; Long et al., 1994; Murata et al., 2007). Később széles körben elfogadottá vált, hogy a legtöbb esetben a fotoinhibíció alacsony mértékü, és a qI a qE-hez hasonlóan a gerjesztési energia hődisszipációjából származik. Különböző hipotézisekkel próbáltak magyarázatot találni a qI látszólagos irreverzibilitására: tartós transzmembrán $\Delta \mathrm{pH}$ (Gilmore \& Yamamoto, 1992), stabil fehérje protonáció (Horton et al. 1994), inaktív PSII RC-ok felhalmozódása (Briantais et al., 1992; Schansker \& van Rensen, 1999), vagy a Zea stabil kötődése a CP29 proteinhez (Färber et al., 1997).

A qT komponens "state" átmenettel való kapcsolatát néhányan szintén megkérdőjelezik, és manapság úgy vélik, hogy a PSI-ről PSII-re történő, az energia újraeloszlása magas fényintenzitás esetén elhanyagolható (Walters \& Horton, 1991; 1993), illetve a qT-nek más eredetet feltételeznek (Schansker et al., 2006).

Az NPQ mechanizmusát tekintve számos ellentmondásos bizonyíték létezik. Még tisztázásra vár, hogy vajon a fényindukált, reverzibilis NPQ a de-excitáció egyetlen mechanizmusát képviseli-e egyetlen helyen, melyet a PsbS és a Zea kombinált müködése idéz elő (Johnson et al., 2009), vagy több párhuzamos és nagyrészt független mechanizmust foglal magában, melyek a PSII antenna különböző részein müködnek. Különböző antenna 
komplexek szisztematikus eliminációja az NPQ kapacitás csökkenéséhez vezet (Andersson et al., 2001; 2003; Kovács et al., 2006), jóllehet az NPQ még a megszakított (intermittent) fény körülmények mellett nevelt, Chl $b$ hiányos mutáns növényekben sem tünt el egészen, amikor csupán a PSII "core" komplex felhalmozódása figyelhető meg (Härtel \& Lokstein, 1995; Härtel et al., 1996). Egy újabb modell szerint az NPQ-nak legalább három független mechanizmusa vagy helye létezik (Lambrev et al., 2010). Betterle és munkatársai (2009) feltételezik, hogy egy antenna hetero-oligomer fényindukált disszociációja szükséges az NPQ kialakulásához, mely két monomer Lhcb fehérjét (CP29 és CP24) és a trimer LHCII-M (közepesen kötött, M) komplexet tartalmazza.

Általánosan az a nézet terjedt el, hogy az NPQ az LHCII-ben lokalizálódik (Horton et al., 1996). Ezt támasztják alá a következő megfigyelések: a kioltás összefüggésben van az antenna fluoreszcencia szignifikáns csökkenésével, miközben valamennyi RC nyitott állapotban van $\left(\mathrm{F}_{\mathrm{o}}\right)$ (Horton \& Ruban, 1993), amely folyamat 77K hőmérsékleten tovább tart, és az LHCII-ből származó kioltott fluoreszcencia sávokkal van kapcsolatban (Ruban et al., 1991); leveleken mért időfelbontásos fluoreszcencia adatok is alátámasztják az antennában végbemenő kioltást (Genty et al., 1992); hőemisszió direkt mérésével NPQ körülmények mellett kimutatták, hogy ez 1,4 $\mu$ s-on belül megy végbe, mely sokkal gyorsabb, mint a PSIIben bekövetkezö rekombinációs folyamatok becsült sebessége (Mullineaux et al., 1994); keresztkötő vegyületek blokkolják az NPQ-t, valamint az izolált LHCII komplexek átszerveződését, ami elősegíti a hődisszipáció kialakulását (Ilioaia et al., 2008); az NPQ és az LHCII azonos módon reagál számos tényező esetében: antimicin A, tercier aminok és magnézium ionok hatására (Noctor et al., 1993; Ruban et al., 1994); az NPQ igen nagymértékben függ a kizárólagosan LHCII-kötött xantofilloktól, a Lut-töl és a Zea-tól (Ruban et al., 1994; Niyogi et al., 2001). Horton és munkatársai (2005) hipotézise szerint az LHCII-ben lokalizálódó qE Chl-Chl és/vagy xantofill/Chl kölcsönhatásokat foglal magában. E modell az LHCII négy különböző strukturális/funkcionális állapotát írja le - nem-protonált és protonált állapotok, Vio vagy Zea kötődése mellett. E jelenlegi aggregációs modell állítása szerint az NPQ a PSII antenna makrostruktúrájától függ, semmint egyetlen fehérjétől. Az LHCII fehérjék egzakt szupramolekuláris rendezettsége mintegy elöfeltétele lehet az energiafüggő kioltásnak. A xantofill ciklus pigmentek nagyobb része inkább gyengén kötődhet a trimer LHCII-höz. A xantofill ciklus karotinoidokat allosztérikus szabályozóknak vélik, 
melyek a fénybegyüjtő komplexek periferiális allosztérikus oldalaihoz kötődnek (L2, V1 helyek) (Horton et al., 2005).

\subsubsection{A xantofillok szerepe a hödisszipáció folyamatában, a xantofill ciklus-függö és független} nem-fotokémiai kioltás

A PSII antenna egy magasan szervezett, dinamikusan müködő rendszer, mely képes a RC-hoz érkező gerjesztés mennyiségét összehangolni a fiziológiai szükséglettel (Horton et al., 1996). Az energiaáramlás szabályozása a többlet gerjesztés hődisszipációján keresztül valósul meg a PSII antennájában. Az in vivo kialakuló maximális $\mathrm{qE}$ kapcsolatban van az epoxi-xantofill violaxantin anteraxantinon keresztüli zeaxantinná való enzimatikus de-epoxidációjával a xantofill ciklus müködése során (3. ábra) (Demmig-Adams, 1990). A fotokonvertibilis xantofill ciklus pigmentek legnagyobb része a trimer LHCII-höz kapcsolódik a külső V1 kötőhelyen (Ruban et al., 1999; 2002a; Caffarri et al., 2001; Liu et al., 2004). A trimer LHCII két, más típusú xantofillt is köt internálisan: két luteint az L1 és L2 helyeken és egy neoxantint az N1 helyen (Liu et al., 2004).

Úgy tartják, két eltérő kioltási mechanizmus létezik, az egyikben (I. típus) a Zea, a másikban (II. típus) a Lut a közremüködő. Úgy gondolták, hogy az I. típusú mechanizmusban a qE obligát módon függ a Zea-tól, mely mintegy a gerjesztett Chl kioltójaként müködik a töltés transzfer állapot kialakulása során. Az I. típus meglétére az a megfigyelés szolgált bizonyítékul, hogy egy, kb. 1000 nm-nél elnyelö, karotinoid gyök kation kialakulása kölcsönös össszefüggést mutatott a qE mértékével (Holt et al., 2005). Újabban úgy tartják, hogy a Zea gyök kation kialakulása kizárólagosan a minor antenna komplexek L2 kötőhelyén megy végbe (Ahn et al., 2008; Avenson et al., 2008), a kioltáshoz így a Zea reverzibilis beillesztése szükséges ebbe a belső környezetbe. Mivel úgy találták, hogy e kation igen csekély mértékben hat a minor antenna komplexek gerjesztett-állapot életidejére, felmerült az, hogy in vivo a komplexek nagyszámban vehetik fel azt a konformációt a $\Delta \mathrm{pH}$ kialakulásának eredményeként, amelyben ez a kation képes kialakulni (Avenson et al., 2008). Igazolták továbbá azt is, hogy a Zea gyök kation a trimer LHCII-ben is létrejöhet (Amarie et al., 2007). Mivel azonban a Chla gerjesztett-állapot életidejére ez a hatás igen csekélynek bizonyult, arra 
jutottak, hogy az I. típusú mechanizmus nem lehet felelős a qE kialakulásáért (Amarie et al., 2007; Dreuw \& Wormit, 2008).

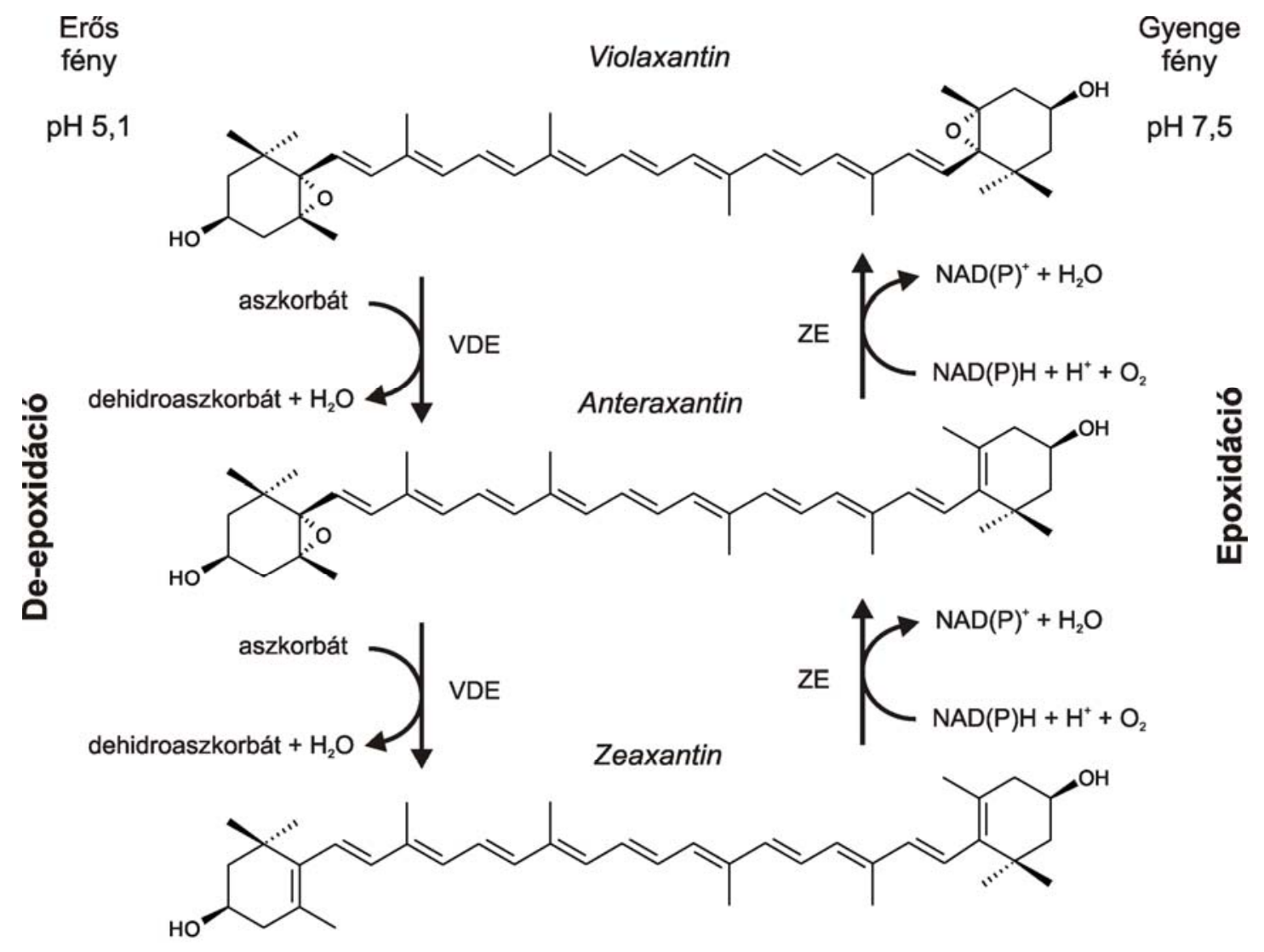

3. ábra A xantofill ciklus komponensei. A fotokémiai telitési fényintenzitást meghaladó erösségü megvilágitás hatására a de-epoxidáz enzim müködésbe lép és két lépésben eltávolitja a lánc végi oxigén atomokat, ezáltal megnövelve a konjugált kettős kötések számát (9-röl 11re). A de-epoxidáció percek alatt lezajlik, míg a forditott irányú folyamat (epoxidáció) ennél lassab, több percet, esetleg órát vesz igénybe.

A II. típusú mechanizmus esetében a qE az LHCII fehérjék egy belső sajátsága; a fehérje konformációjának változása módosítja a kötött pigmentek konfigurációját, valamint az L1 helyen kötött xantofill (rendes körülmények között Lut) hatékony kioltóvá válását 
eredményezi (Ruban et al., 2007; Ilioaia et al., 2008). A II. típusú mechanizmus létezése a trimer LHCII aggregátumok tanulmányozása révén nyert bizonyságot (Ruban et al., 2007), melynek folyamán arra a következtetésre jutottak, hogy az energia disszipáció a Chla-ról az L1 helyen kötődő Lut felé történő energiatranszferrel valósul meg. Ez a kioltási mechanizmus olyan mértékben csökkenti a Chla gerjesztett-állapot életidejét, mely teljes egészében magyarázatul szolgálhat a qE-re in vivo. Egy másik LHCII kötött xantofill (neoxantin) konformációjában bekövetkező változás kölcsönösen összefügg a kioltás mértékével. Ez a konformáció változás olyan sebességgel megy végbe in vivo, amely a $\mathrm{qE}$ nagyságával korrelációt mutat. A Horton és munkatársai $(1991 ; 2005)$ által javasolt II. típusú kioltási modellben a Zea nem kioltóként, hanem mintegy allosztérikus regulátor müködik, amely e belső LHCII kioltási folyamat $\Delta \mathrm{pH}$ érzékenységét szabályozza.

Habár az I. és II. típusú mechanizmusok az LHCII-n belül eltérő helyeken található xantofillokat foglalnak magukban, hasonlóságok is vannak közöttük: úgy hiszik, mindkét folyamat magában foglal egy $\Delta \mathrm{pH}$ által kiváltott, PsbS fehérje által mediált konformáció változást (Ruban et al., 2007; Ahn et al., 2008). Valószínüleg mindkét mechanizmus hozzájárulhat az in vivo $\mathrm{qE}$ kialakulásához, mivel a folyamat végbemegy mind Zea jelenlétében, mind hiányában (Adams et al., 1990; Crouchman et al., 2006). A sötétadaptált levelek megvilágítása során kialakuló NPQ kinetikája két komponensből áll: az első gyorsan kialakul és Zea független; a második, lassabb komponens korrelál a Vio de-epoxidációval és ezért Zea-függőnek mondhatjuk (Adams et al., 1990; Ruban \& Horton, 1999). Az NPQ mindkét komponense qE típusú: gyorsan relaxálódnak a sötétben (Adams et al., 1990), mindkettő függ a PsbS-től (Li et al., 2000), és mindkettőt fokozza a PsbS túlexpressziója (Li et al., 2002b; Crouchman et al., 2006).

Az 535 nm-en mért abszorbció változásról $\left(\Delta \mathrm{A}_{535}\right)$ úgy tartják, hogy a PSII antennában végbemenő konformáció változásból ered, mely a kioltott állapot kialakulását kíséri (Ruban et al., 1993b; Bilger \& Björkman, 1994). Johnson és munkatársai (2009) úgy találták, a $\Delta \mathrm{A}_{535}$ érzékeny mind a monomer minor, mind a trimer LHCII fehérjék elvesztésére. Tehát a $\Delta \mathrm{A}_{535}$ összefüggést mutatott mind a Zea-függő, mind a Zea-független $\mathrm{qE}$ komponensekkel, ez utóbbiban a rövidebb hullámhosszak felé való elmozdulásban a xantofillok részvétele tükröződik. Ezek az eredmények (Johnson et al., 2009) a korábbiakkal együtt, bizonyítani látszanak a Lut fontosságát a maximális, teljes qE kialakulásában (Pogson et al., 1998; Pogson 
\& Rissler, 2000). Feltételezik, hogy a Lut hiányában a PSII antennafehérjék szerkezetében bekövetkező destabilizáció (Lokstein et al., 2002; Havaux et al., 2004), az egyes monomerek szintjén, hátrányosan befolyásolja a kioltott állapot kialakulásához vezető konformáció változások létrejöttét. Az npq2 és lut2npq2 mutáns Arabidopsis thaliana (A. thaliana) növényekben a Zea konstitutív jelenléte a $\Delta \mathrm{A}_{535}$ amplitudójának növekedését eredményezte, miközben lut2npq2 mutánsokban ezt a növekményt a qE csökkenése kísérte (Johnson et al., 2009). Ez az eredmény, egyetértésben mások megfigyelésével (Kalituho et al., 2006), arra enged következtetni hogy az abszorpció változás nem tükrözi közvetlenül egy kioltó molekula kialakulását. Ezért a $\Delta \mathrm{A}_{535}$ abszorpció változásról Johnson és munkatársai (2009) úgy tartják, hogy az azokat a szerkezeti változásokat jeleníti meg, melyek összefüggésben vannak a $\mathrm{qE}$ Zea általi felerősödésével. Igazoltnak látszik tehát, hogy mind a Zea-független, mind a Zeafüggő qE komponens egyazon mechanizmusból származik a PSII antennájában. Mindkettő preferenciálisan az LHCII fluoreszcencia emmissziós sávokat oltja ki (Ruban et al., 1991), valamint mindkét qE komponens amplitudója kisebb volt Lut hiányában (Pogson et al., 1998; Niyogi et al., 2001). A monomer minor és a trimer LHCII fehérje-összetétel módosítása befolyással bír mindkét mechanizmusra, és mindkét folyamatot konformáció változások kísérték, melyek hatására nagyon hasonló abszorpció változásokat tapasztaltak a Soret régióban (Johnson et al., 2009). Úgy hiszik, hogy ezek a megfigyelések megfelelnek a II. típusú mechanizmusnak, amely magában foglalja az LHCII konformáció változása által aktivált L1 helyen kötődő xantofillt, mely változás a neoxantin eltorzulásához vezet (Ruban et al., 2007), valamint a V1 hely de-epoxidációs állapota ezt mintegy allosztérikusan szabályozza (Horton et al., 2005). Ez a folyamat feltételezések szerint néhány vagy minden Lhcb tartalmú antennakomplexben bekövetkezhet (Ruban et al., 1996; Mozzo et al., 2008). Johnson és munkatársai (2009) lehetséges alternatívája értelmében az I. típusú mechanizmus előfordulhat mind a trimer LHCII, mind a monomer minor antennában, illetve a Zea hiányában a Lut kation foglalhatja el a helyét kioltóként.

\subsubsection{A PsbS fehérje szerepe a hödisszipáció folyamatában}

A sejtmagi $n p q 4$ gén által kódolt PsbS fehérje egy $22 \mathrm{kDa}$ tömegü PSII alegység, amely a fénybegyüjtő komplex család tagja, és ami Zea-kötö tulajdonsággal is rendelkezik (Jansson, 
1999). A PsbS fehérjének, a legtöbb LHC fehérjétől eltérően, melyek három transzmembrán hélixet tartalmaznak, négy transzmembrán hélixe van, valamint pigmentkötő tulajdonságai is eltérnek más LHC fehérjékétöl.

Az npq4 deléciós mutáns $A$. thaliana növényekben a PsbS fehérje teljesen hiányzik. Ezekben a mutánsokban a qE nem alakul ki 5-10 perc megvilágítás után, azonkívül a jellegzetes $\Delta \mathrm{A}_{535}$ szintén hiányzott e mutánsokból (Li et al., 2000; Ruban et al., 2002b). E növények megnövekedett fényérzékenységét fotoinhibíciós körülmények között ( $\mathrm{Li}$ et al., 2002a), valamint csökkent növekedésüket és magprodukciójukat (Külheim et al., 2002) a qE látszólagos hiányának tudták be.

A PsbS fehérjéről feltételezték, hogy a tilakoid membránban, a qE kialakulásának helyén kulcsfontosságú, fotoprotektív szerepet tölt be (Li et al., 2000; 2004), később pedig azt, hogy mind a $\Delta \mathrm{pH}$ érzékelöjeként (Dominici et al., 2002; Li et al., 2004), mind a vélelmezett karotinoid Zea kioltó kötőhelyeként müködik (Li et al., 2004). Azonban ez a teória később megkérdőjeleződött, mivel a PsbS protein Zea hiányában is betöltötte funkcióját (Crouchman et al., 2006), és a rekonstituált fehérje nem kötött semmilyen pigmentet (Dominici et al., 2002; Bonente et al., 2008). Az npq4 A. thaliana mutánsok levelein és izolált kloroplasztiszain végzett kísérletek alapján Horton és munkatársai (2000) azt az alternatív magyarázatot javasolták, hogy a PsbS fehérje indirekt módon, mintegy a konformáció változások modulátoraként müködik, előidézve az LHCII-n belüli kioltást. Egyesek azt feltételezik, hogy a $\triangle \mathrm{pH}$ kialakulásának következtében a PsbS oligomerizációs állapota megváltozhat és ezáltal áthelyeződhet a tilakoid membránban (Bergantino et al., 2003; Teardo et al., 2007). Mások szerint a PsbS hatással lehet a tilakoid membrán dinamikára, összefüggésben a gránum szerkezet kialakulásával ("stacking”) és a PSII-LHCII komplexek makroorganizációjával (Kiss et al., 2008; Betterle et al., 2009). Tehát az elmúlt évek kutatásai alapján úgy tünik, a PsbS fehérje szerepet játszhat a $\Delta \mathrm{pH}$-érzékeny NPQ beindításában, lehetővé téve egy vagy több LHCII antennafehérje szerkezeti változását, amely az NPQ állapot indukciójához szükséges (Horton et al., 2000; 2008; Dominici et al., 2002; Teardo et al., 2007; Kiss et al., 2008; Betterle et al., 2009; Johnson et al., 2009). Legújabban Johnson és Ruban (2010) kimutatták, hogy az npq4 növények kompetens fotoprotektív energia disszipációs mechanizmussal bírnak, azonban ez jóval lassabban alakul ki és relaxálódik, mint a vad típusban. E mutánsok leveleiben a meghosszabbított megvilágítás/sötétség hatására a vad 
típushoz rendkívül hasonló változásokat figyeltek meg a kulcs fluoreszcencia kioltási paraméterek és a $\Delta \mathrm{A}_{535}$ abszorpció változás tekintetében. Ezenfelül mások úgy találták, hogy az NPQ kialakulását és relaxációját a PsbS meggyorsítja a túlexpresszáló vonalakban a vad típushoz képest (Crouchman et al., 2006). Kimutatták, hogy a $\Delta \mathrm{A}_{535}$, mely a vörös-eltolódott Zea szubpopuláció kialakulásából származik az NPQ alatt (Ruban et al., 1993a; 2002), nem igényel PsbS-t. A Zea szubpopuláció lehetséges eredete azonban ma még egy nyitott kérdés. Johnson és Ruban (2010) kutatási eredményei rávilágítottak arra, hogy a kioltó nem a PsbS-en lokalizálódik; az NPQ a fehérje hiányában is kialakul, ekképpen a $\Delta \mathrm{pH}-\mathrm{t}$ a tilakoid membrán még mindig érzékeli, valószínüleg bizonyos LHCII fehérjék savas csoportjai által, melyeket diciklohexilkarbodiimid kötőhelyekként azonosítottak (Walters et al., 1994; 1996). Ezek szintén azt a nézetet támogatják, mely szerint az LHCII és/vagy a minor antenna fehérjék az NPQ helyeként funkcionálhatnak (Ruban et al., 2007; Ahn et al., 2008). A PsbS fehérje qE kialakulásában betöltött kinetikai szerepének pontos mechanizmusa jelenleg még nem ismert. Johnson és Ruban (2010) az npq4 növényekben a megváltozott NPQ kinetika elsődleges okának a rigidebb és kevésbé flexibilis PSII makroorganizációját (Kiss et al., 2008; Betterle et al., 2009) tekintik, mely támogatja azt az elképzelést, hogy a PsbS egy dimanikai szerepet játszik a tilakoid membrán szerveződésében (Teardo et al., 2007). E nézet szerint a PsbS lokalizációja megváltozhat az NPQ állapotban, előidézvén bizonyos obligát változást a PSII makroorganizációjában (Betterle et al., 2009), mely ellenkező esetben inkább lassú lenne; avagy a PsbS mintegy vektor müködhet, amely a protonokat az LHCII fehérjék felületén koncentrálja, ezzel elősegítve azok NPQ állapotba való gyors átkapcsolását.

\subsection{A vízdeficit hatása a magasabbrendü növények fotoszintézisére}

2.2.1. A vízhiány fokozatainak jellemzése, a sztomatikus és a nem-sztomatikus limitáció értelmezése

A növények életük során gyakran ki vannak téve a szárazságnak, ami az alacsony talajvíztartalom vagy az atmoszférikus vízhiány következménye. A fotoszintézis valamint a sejtnövekedés azok közé a folyamatok közé tartoznak, amelyek a szárazság által elsődlegesen érintettek (Chaves, 1991). A szárazság hatásai lehetnek közvetlenek, mint például a sztómákon 
vagy a mezofillumon keresztüli diffúzió limitációja, amely csökkenti a széndioxid elérhetőségét (Flexas et al., 2004; 2007), vagy a fotoszintetikus metabolizmus módosulása (Lawlor \& Cornic, 2002), avagy mint másodlagos hatások jelentkezhetnek oxidatív stresszként (Chaves \& Oliveira, 2004). Ez utóbbi a többszörös stresszkörülmények alatt javarészt bekövetkezik (Chaves \& Oliveira, 2004) és súlyosan befolyásolhatja a fotoszintézist (Ort, 2001).

A gázcserenyílások záródása figyelhető meg a levelek turgorának csökkenésekor, az atmoszférában a relatív páratartalom csökkenése esetén, vagy a gyökér által termelt kémiai jelmolekulák hatására. Az atmoszférikus széndioxidnak a kloroplasztisz sztrómába, vagyis a fotoszintézis helyére való bejutásának számos limitáló faktora van (sztomatikus és nemsztomatikus limitáció). A $\mathrm{CO}_{2}$ elöször a külső környezetböl a levelek sejtközötti járataiba diffundál a sztómákon keresztül, melyek nyitottsága szabályozza a légudvarba jutó $\mathrm{CO}_{2}$ mennyiségét (Farquhar \& Sharkey, 1982; Assmann et al., 1988). A gázcserenyílások e szabályozó szerepét sztomatikus limitációnak nevezzük. A sztomatikus limitáció relatív mértéke a vízdeficit erősségétől függ. Enyhe szárazság alatt a sztómazáródás az első lépés, amelyet szükségszerüen a fotoszintetikus széndioxid asszimiláció csökkenése követ (Chaves, 1991; Cornic \& Briantais, 1991). Enyhe stressz esetén az alacsony sztóma vezetőképességnek $\left(\mathrm{g}_{\mathrm{s}}\right)$ protektív hatásía lehet, elősegítve a vízmegőrzést és növelve ezzel a növény vízhasznosítási képességét. Rendszerint a sztómák válaszreakciói szorosabb összefüggést mutatnak a talaj nedvességtartalmának mint a levél vízállapotának megváltozásával. Ezek alapján feltételezik, hogy a sztómák reagálnak a dehidratált gyökerek produktumaira (pl. az abszcizinsav), mint kémiai jelmolekulákra (Davies \& Zang, 1991). Lawlor (2002) kutatásai szerint a növényi sejtek szénmetabolizmusának megváltozása valószínúleg szintén előfordul a dehidráció korai szakaszában. A szárazságtürő fajok a sztómamüködésük szabályozása révén bizonyos mértékü szén-asszimilációt képesek fenntartani szárazság alatt, vagy a vízhiány megszüntekor gyorsan nyitják sztómáikat. A vízdeficit korai biokémiai hatásai magukban foglalják a fotofoszforilációban bekövetkező változásokat (az ATP mennyiségének csökkenése a ribulóz 1,5-biszfoszfát (RuBP) regenerációjának csökkenéséhez vezet) (Tezara et al., 1999), amelynek mértéke fajfüggő (Lawlor \& Cornic, 2002).

Ahogyan a sztómák záródnak, a $\mathrm{CO}_{2}$ moláris frakciója csökken a levelek kloroplasztiszaiban. Ezáltal a ribulóz 1,5-biszfoszfát karboxiláz oxigenáz (Rubisco) enzim 
$\mathrm{CO}_{2}$ ellátása meggyengül, amelynek következményeként a $\mathrm{C}_{3}$ típusú növények $\mathrm{RuBP}$ oxigenációja emelkedik és a fotoszintetikus elektronok fő fogyasztójává válik. Megfigyelték a fotoszintetikus aktivitás csökkenését magas fényintenzitás és hömérséklet mellet, és vízhiány hatására az energia disszipáció mértékének fokozódását a fotoszintetikus apparátusban. Az ún. nem-sztomatikus limitáció elemei közé tartozik a mezofillum limitáció. A mezofill konduktancia $\left(\mathrm{g}_{\mathrm{m}}\right)$ (Flexas et al., 2004; 2007) megváltozása kapcsolatban lehet a sejtközötti járatok szerkezetének fizikai módosulásával a levél fonnyadásakor (Lawlor \& Cornic, 2002), vagy a biokémiai változásokkal (bikarbonát $\rightarrow \mathrm{CO}_{2}$ konverzió), és/vagy a membrán permeabilitással (akvaporinok). Genty és munkatársai (1998) kutatásai azonban arra világítottak rá, hogy a $\mathrm{CO}_{2}$ diffúzióval szembeni internális rezisztencia javarésze a sejteken belüli folyadékfázisban található. Ezt a nézetet támogatják mások is (Flexas et al., 2006; 2008), a g $g_{m}$ ezek alapján inkább biokémiailag szabályozott, semmint egyszerüen a levél anatómiai tulajdonságai által. Vízmegvonásos kísérletekkel demonstrálták, hogy a $\mathrm{CO}_{2}$ asszimiláció intenzitásának szignifikáns csökkenése a számottevően megnövekedett metabolikus limitációnak, semmint a sztómalimitációnak tudható be (Lawlor, 2002; Flexas et al., 2006). A lecsökkent fotoszintetikus elektron felhasználás egy közvetlen következménye annak, hogy a szárazság az elérhető $\mathrm{CO}_{2}$ mennyiségének csökkenését idézi elő, ill. növeli egyéb alternatív elektrontranszport utak kialakulásának valószínúségét, úgymint a fotorespiráció és a Mehler-reakció (Cornic \& Freseau, 2002). A metabolikus limitáció biofizikai és biokémiai folyamatok következménye, melyek müködése $C_{3}$ növényekben bizonyos mértékben tisztázott (Lawlor, 2002; Flexas et al., 2006). A Rubisco tartalmának (Tezara et al., 2002) és aktivitásának (Tenhunen et al., 1984) megváltozását; az ATP lecsökkent szintézisét ill. a RuBP regenerációjának csökkenését (Flexas \& Medrano, 2002); a klorofill tartalom lecsökkenését ill. az alacsonyabb fotokémiai hatásfokot (Ögren \& Öquist, 1985; da Silva \& Arrabaça, 2004; Flexas et al., 2006) a metabolikus limitáció elemeinek tekintik.

Tartós stresszkörülmények alatt megfigyelhető a Rubisco enzim deaktivációja alacsony intercelluláris $\mathrm{CO}_{2}$ koncentráció $\left(\mathrm{C}_{\mathrm{i}}\right)$ esetén (Meyer \& Genty, 1998). Amikor a szárazság mellett a növényeket egyéb stresszhatások is érik, úgymint magas fényintenzitás és

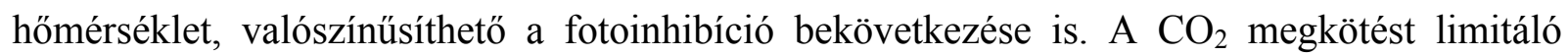
körülmények között a redukáló erők keletkezése gyorsabb, mint azok Calvin ciklus általi 
felhasználása. A hosszantartó száraz periódus alatt a levél víztartalma lényegesen visszaesett borsó növényekben, ami a PSII “core” komplexek mennyiségének jelentős csökkenéséhez vezetett. A megmaradó PSII komplexek funkcionálisan müködőképesnek bizonyultak, illetve újraszerveződtek. A vizsgálatok alapján a CP43 komplex valamint a D1 protein fokozottan degradálódtak szárazság alatt (Girardi et al., 1996). Mások is alátámasztják ezt a megfigyelést, miszerint a nagyobb PSII fehérjék egyensúlyi szintje, beleértve a D1 és a D2 proteineket, a szárazság előrehaladtával csökken, ami feltehetőleg a megnövekedett degradációnak köszönhető. A vízdeficitnek a PSII proteinek metabolizmusára gyakorolt hatása indokolhatja, különösképpen a RC fehérjék esetében, a PSII fotokémiájának károsodását (He et al., 1995). Továbbá kimutatták, hogy a vízmegvonás hatására nagyobb mértékben emelkedik a PSII- $\beta$ inaktív centrumok mennyisége a szárazságra érzékeny borsó változatokban, mint a szárazságra toleránsakban (Yordanov et al., 1997; Gonzales et al., 2001). A membránlipideknek kulcsfontosságú szerepük van a növényi sejtek szintjén a rezisztencia kialakulásában a különféle környezeti faktorokhoz történő akklimatizáció során (Kuiper, 1980; Suss \& Yordanov, 1986). Erös vízhiány esetén zavart szenved a membránlipidek és proteinek közötti asszociáció, valamint enzimaktivitás csökkenés és a membrán kettősréteg transzport kapacitásának csökkenése tapasztalható (Caldwell \& Whitman, 1987). A szárazságra érzékeny növényekben számottevően nagyobbnak bizonyult a zsírsavbontás stimulációja, mint a szárazságra toleránsabb változatokban (Sahsah et al., 1998). A neutrális lipidek mennyiségének csökkenése a levélben föként a monogalaktozil-diacil-glicerol (MGDG) tartalom csökkenésének köszönhető, és az MGDG/digalaktozil-diacil-glicerol (DGDG) arány ugyancsak lecsökkent (Benhassaine-Kesri et al., 2002).

\subsubsection{A védekezö/szabályozó folyamatok szerepe a vizhiány kivédésében}

A növények számos protektív mechanizmust fejlesztettek ki fotoszintetikus apparátusuk védelme érdekében a környezeti faktorok károsító hatásaival szemben. Bohnert és Shen (1999) kutatásai szerint csaknem univerzális válaszreakciónak tekinthető stresszkörülmények alatt, beleértve a szárazságot is, az ozmotikus szabályozás révén különféle kompatibilis ozmotikumok felhalmozása. Az ozmoreguláció a növény számára kedvezőbb vízpotenciál grádiens kialakulását teszi lehetővé, ezáltal hozzájárul a sejt turgorának fenntartásához (Zhang 
et al., 1999). Így a vízhiány bizonyos mértékig elkerülhető vagy jelentős mértékben csökkenthető. Ezek a vegyületek föként alkilaminok vagy polihidroxil vegyületek, valamint szacharidok és ezek polihidroxil származékai. A stresszfiziológiában általánosan elfogadott szerepük az ozmoreguláció, ezen kívül más funkcióval is rendelkezhetnek, nevezetesen az enzimek és a membránszerkezet védelmét biztosítják, valamint a reaktív oxigén gyökök eliminálásában is részt vehetnek.

Szárazság alatt a többlet redukáló erő elleni fotoprotektív mechanizmusok igen fontosak. Ezek a fotokémiával versengenek az elnyelt energiáért, amely a PSII hatásfokának csökkenéséhez vezet (Genty et al., 1989). Az egyik legfontosabb fotoprotektív mechanizmus a növényekben, hogy elkerüljék vagy csökkentsék a fotoszintetikus apparátusuk károsodását, a klorofill fluoreszcencia nem-fotokémiai kioltása (Ruban \& Horton, 1995), melynek során a gerjesztési többletenergia hőként disszipálódik a PSII antenna komplexében. Golding és Johnson (2003) vizsgálataik során azt a megfigyelést tették, hogy az 'aktív' PSI centrumok aránya megemelkedett a száraz periódus alatt. Feltételezéseik szerint ezek elsődlegesen a ciklikus elektrontranszportban vesznek részt, amely a $\Delta \mathrm{pH}$ fokozásával hozzájárul a nemfotokémiai kioltás fenntartásához, és megvédi a PSII-t. A regulált termális disszipáció valamiképpen magában foglalja a xantofill ciklust (Demmig-Adams \& Adams, 1996) és a lutein ciklust (Matsubara et al., 2001), jóllehet utóbbi szerepe nem teljesen világos még. A levelek alacsony víztartalma mellett a $\mathrm{CO}_{2}$ asszimiláció és ezáltal az ATP felhasználás csökken, miközben a funkcionális elektrontranszport müködése proton akkumulációt eredményez a tilakoid lumenben, ami a Zea és az Ant képződésének kedvez. Úgy vélik, hogy a fotoprotektív folyamat müködése által elvezetődik az energia a reakciócentrumokból (Ruban \& Horton, 1995). Vannak azonban olyan kísérleti adatok is, amelyek nem támasztják alá azt a megállapítást, miszerint a xantofill ciklus jelentős vagy specifikus szerepet játszik az elnyelt fényenergia közvetlen energia disszipációjában (Schindler \& Lichtenthaler, 1994). Tambussi és munkatársai (2002) kutatásai szerint a fluoreszcencia nem-fotokémiai kioltása, valamint a Zea+Ant tartalom a közepes vízhiány következtében szignifikánsan megemelkedett. Jóllehet, az erős szárazság által indukált xantofillok mennyiségének további növekedése nem hozható kapcsolatba a hődisszipáció mértékének emelkedésével. Kimutatták továbbá a $\beta$-karotin tartalom erős szárazság által kiváltott szignifikáns emelkedését, amely az antioxidáns védekezés fokozódását jelezheti. 
A fotorespiráció szintén részt vehet a fotoszintetikus apparátus védelmében a magas fényintenzitás károsító hatásával szemben, ahogyan ez a jelenség szárazság alatt néhány faj esetében megfigyelhető (Chaves et al., 2003). A fotorespiráció által termelt hidrogénperoxidnak szerepet tulajdonítanak a jelátvitelben és az akklimatizáció folyamataiban, amikor a $\mathrm{CO}_{2}$ hozzáférése limitált (Noctor et al., 2002). Az antocianinok felhalmozódása, melyek a fotooxidatív károsodást védik ki a sejtekben, különösen fontosak lehetnek öregedő levelekben, melyekből így hatékony tápanyag visszanyerés folyik a növény raktározó kompartmentumaiba (Feild et al., 2001).

\subsubsection{Stratégiák a vízhiány tolerálására}

A növény túlélőképessége az egész növényre jellemző mechanizmusoktól függ, melyekkel megfelelően tud reagálni a sejtszintű vízhiányra. A szárazságtürési stratégiák különbözőek lehetnek. A szárazságot toleráló növények a dehidratáltság ellenére képesek az élettani funkcióik megtartására. Az elkerülö stratégia esetén a növények még a nedves évszakban befejezik az életciklusukat, a száraz periódus előtt. A vízpotenciál csökkenését kivédő növények képesek fenntartani a szövetek hidratáltságát, ezen belül vagy vízmegőrző stratégiát követnek, vagy a vizet továbbra is nagy mennyiségben fogyasztják, de gondoskodnak annak pótlásáról, például mélyebb gyökérzet segítségével. A CAM (Crassulaceae Acid Metabolism) növények adaptációs elönyben vannak, mivel azok nappal zárva tarthatják a sztómáikat, csökkentve ezzel a párolgási veszteséget, és lehetővé téve ezzel túlélésüket erősen vízhiányos, sokszor félsivatagi, sivatagi körülmények között is.

A zárvatermők egy csoportja, melyeket újraéledő növényeknek nevezünk, képesek a szélsőséges vízvesztést is elviselni (Bernacchia \& Furini, 2004); a hosszú száraz periódus alatt nyugalomban maradnak, majd a rehidráció után újraélednek. A dehidráció számos transzkriptum expresszióját indukálja az újraéledő növényekben, ezek közül a védő funkcióval rendelkező géntermékek közül azonosították a LEA (Late Embryogenesis Abundant) fehérjéket, melyek a citoplazmában magas szinten fejeződnek ki a dehidráció és/vagy a vegetatív növényi szövetek abszcizinsav-kezelésének következtében. Általában a cukrok koncentrációjának megemelkedése is megfigyelhető a deszikkáció kezdetekor ezekben a 
növényekben, ezek hatásosak lehetnek az ozmotikus szabályozásban, vagy a membránstruktúrát és a fehérjéket stabilizálhatják.

\subsection{Az atrazin rezisztencia}

A herbicid-rezisztens gyomnövények felbukkanása főként a müvelés alatt álló területekhez kapcsolódik. A triazin-típusú gyomírtószerek reguláris és intenzív használata a különböző gyomnövények esetében rezisztens biotípusok felszaporodását eredményezte. A D1 fehérje, ami a PSII RC alkotója, nem csupán a PQ redukciójának a színtere, hanem herbicidek kötőhelyeit is tartalmazza. A PSII-t gátló herbicidek specifikusan és hatékonyan blokkolják a PQ redukcióját azáltal, hogy kompetitíven kiszorítják a $\mathrm{Q}_{\mathrm{B}}$ kinon formáját a kötőhelyéről (Velthuys, 1981; Arntzen et al., 1982; Vermaas et al., 1983). A Q kiszorítása után az inhibítorok szerkezetüktől függően elfoglalják a $Q_{B}$ kötőhelyének különbözö, de átfedő részeit, meggátolván a $\mathrm{Q}_{\mathrm{A}}$ felőli elektronáramot a $\mathrm{PQ}$ készlet irányába. A gyomnövényekben előforduló 2-kloro-4-(etilamino)-6-(izopropilamino)-triazin (atrazin) rezisztencia a PSII RC 32 kDa móltömegü, D1 fehérjéjét kódoló, psbA kloroplasztiszban lokalizált gén pontmutációjának tulajdonítható (Hirschberg et al., 1984; Gressel, 1985), melynek következtében a D1 protein láncának 264-es pozíciójában szerin helyett glicin ( $\operatorname{Ser}_{264} \rightarrow$ Gly) jelenik meg (Hirschberg \& McInthosh, 1983; Hirschberg et al., 1984). Ez nemcsak az atrazinnak а $\mathrm{Q}_{\mathrm{B}}$ kötőhelyhez való affinitását csökkenti drasztikusan, ami a rezisztencia okának tekinthető, hanem a $\mathrm{Q}_{\mathrm{B}}$ kötődését is módosítja (Pfister \& Arntzen, 1979). Ezáltal lelassul a $\mathrm{Q}_{\mathrm{A}}$ és $Q_{B}$ közötti elektronátadás sebessége, ugyanis a kötődési affinitás erősen függ a D1 protein szerinjének hidroxil csoportja és a $\mathrm{Q}_{\mathrm{B}}$ karbonil csoportja (4. A ábra), és az atrazin aminoetilén csoportja közötti hidrogénhidas kötéstől (4. B ábra) (Arntzen et al., 1979; Pfister \& Arntzen, 1979; Trebst, 1991). Az atrazin rezisztenciát kísérő számos, ún. pleiotróp hatás között a lassúbb PSII elektrontranszport sebességet, a PSII-höz kötődő fotokémiai folyamat kisebb hatékonyságát és az AR növények gyengébb produktivitását is általánosan megfigyelték (Holt et al., 1981; Ort et al., 1983; Ireland et al., 1988). Számos szerző úgy tartja, hogy a tilakoid membránok lipid és zsírsav összetételében észlelhető különbségek okozhatják az AR biotípusok magas hőmérsékletekkel szembeni kisebb toleranciáját (Ducruet \& Lemoine, 1985, Havaux, 1989), amely magyarázhatja a gyengébb produktivitást is. 


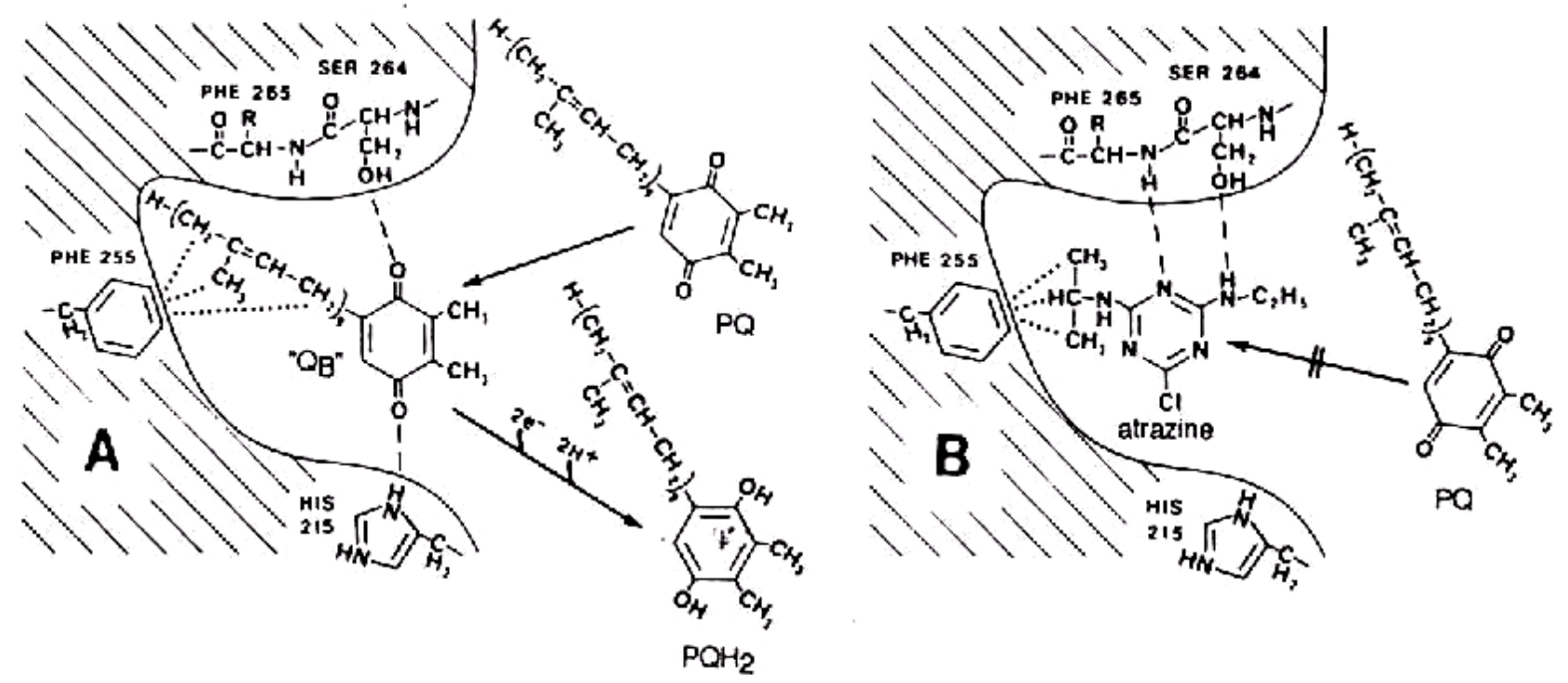

4. ábra $A Q_{B}(\mathbf{A})$ és az atrazin (B) kölcsönhatásának sematikus ábrázolása a D1 fehérje $Q_{B}$ kötőhelyén (Fuerst \& Norman, 1991). A hidrogénhid kötéseket szaggatott, a hidrofób kölcsönhatást pontozott vonalak jelölik. Az atrazin bekötödése korlátozza a PQ kötödését. A mutáció $\left(S e r_{264} \rightarrow G l y\right)$ révén az alacsonyabb fokú hidrogénhíd kötés gyengíti az atrazin (és a $P Q)$ kötödési tulajdonságait.

Nevezetesen, az AR növény kloroplasztiszai több MGDG-t, viszont kevesebb DGDG-t és foszfatidil-gliceridet tartalmaznak az AS növényhez képest. A kloroplasztiszok összes lipidje az AR biotípus esetében nagyobb mérvü telítetlenséget mutat, amely a glikolipid frakció nagyobb linolénsav és kisebb palmitinsav tartalmának köszönhető. A foszfolipidek zsírsav összetétele a foszfatidil-glicerid kivételével nem különbözött. Az AR növények tilakoid membránjainak lipid mátrixa a fluoreszcencia polarizációs mérések tanúsága szerint nagyobb fluiditást mutat az AS növényekéhez viszonyítva (Lehoczki et al., 1985). Az AR biotípusok nagyobb fényérzékenységéről és a fénygátlással szembeni nagyobb érzékenységről egyaránt beszámoltak (Holt et al., 1981, Hart \& Stemler, 1990; Curwiel et al., 1993; Sundby et al., 1993a; Váradi et al., 1994; Darkó et al., 1996; 2000).

A sötétadaptált triazin-rezisztens biotípusú növények levelei nagyobb mennyiségben tartalmaznak redukált $\mathrm{Q}_{\mathrm{A}} \mathrm{-t}$, mint a vad típusé (Pfister \& Arntzen, 1979), ami limitálhatja a töltésszétválasztások számát, csökkentve ezáltal a PSII hatásfokát. Fluoreszcencia kioltás analízis vizsgálatok szintén alátámasztották a $\mathrm{Q}_{\mathrm{A}}{ }^{-}$magasabb "steady-state" koncentrációjának 
meglétét (Curwiel et al., 1993; Sundby et al., 1993b; Darkó et al., 1995; 1996). Ez feltételezhetően a mutációval összefüggő lassabb $\mathrm{Q}_{\mathrm{A}}{ }^{-}$reoxidáció következénye lehet (Váradi et al., 1994). A Chla indukciós görbe kezdeti szakaszában a triazin-rezisztens növényekben legtöbbször magasabb $\mathrm{F}_{\mathrm{i}}$ szintet mértek (Arntzen et al., 1979; Pfister \& Arntzen, 1979; Ducruet \& Lemoine, 1985; Gressel, 1985; Schönfeld et al., 1987), ami a QA prompt fotoredukciójának sebességét mutatja (Melis, 1985). A Váradi és munkatársai (2003) által vizsgált valamennyi AR növény egyértelmüen csökkent fotokémiai hatásfokkal (qP) rendelkezett valamennyi fényintenzitáson.

Schönfeld et al., (1987) ATP szintézis vizsgálatai nem mutattak eltérést Phalaris paradoxa növények vad és mutáns biotípusai között, nem tapasztaltak változást a tilakoid membránon keresztüli protongradiens kiépülésében, ekképpen a foszforiláció folyamata nem különbözött a két biotípusban. Vitatható azonban az a tény, hogy a mutáns növényekben a $\mathrm{Q}_{\mathrm{A}^{-}}$ $\mathrm{Q}_{\mathrm{B}}$ között megfigyelhető 3-10-szer lassabb elektrontranszfer vajon hogyan korlátozhatja a teljes fotoszintetikus elektrontranszportláncot állandósult körülmények között megvilágítás után, vagy vajon a mutáció hatása csupán közvetetten jelentkezik az alacsonyabb fotoszintetikus aktivitásban (Ort et al., 1983; Ireland et al., 1988). A válasz nem nyilvánvaló, mivel a fotoszintetikus elektrontranszport limitáló lépése fiziológiás körülmények között általában a PQ készlet Cyt $b_{6} / f$ komplex általi oxidációja (Genty \& Harbinson, 1996). Alacsony fényintenzitásokon az AR típusok $\mathrm{CO}_{2}$ fixáció sebessége alacsonyabb, mint a vad típusé. A fényintenzitás emelkedésével ez a különbség csökken, és telítési fényintenzitásokon a kétféle biotípus értékei hasonlóak (Holt et al., 1981; Ort et al., 1983; Váradi et al., 2003), néhány esetben az AR mutáns felül is múlja a vad típust (Schönfeld et al., 1987).

Először Váradi és munkatársai (1994) bizonyították, hogy a Conyza canadensis AR biotípusában alacsonyabb a xantofill ciklus aktivitása. Kimutatták továbbá, hogy az AR biotípusokban nagyobb sebességgel müködik a D1 protein degradációs/helyreállítási folyamata (turn over) (Sundby et al., 1993a; Darkó et al., 2000). Elképzelhetőnek tartják, hogy a magasabb fényérzékenység a megemelkedett D1 protein turn over-nek (Sundby et al., 1993a) és/vagy in vivo a xantofill ciklus alacsonyabb aktivitásának (Váradi et al., 1994; Darkó et al., 1995) köszönhető. Továbbá az NPQ alacsonyabb mértékét detektálták AR növényekben magas fényintenzitás mellett (Szigeti \& Lehoczki, 2003). Nem találtak szignifikáns és egyértelmü különbségeket a xantofill ciklus készlet méretében a kétféle biotípus között 
(Váradi et al., 2003). E feltételezés szerint az alacsonyabb qE (az NPQ energiafüggő frakciója) és az alacsonyabb mennyiségű Zea létrejötteért felelőssé tehető egyik mechanizmus talán az alacsonyabb sebességü fotoszintetikus elektrontranszport, amely a tilakoid membránon keresztüli kisebb $\Delta \mathrm{pH}$ létrejöttét eredményezheti, mely alacsonyabb Vio de-epoxidációt von maga után. Darkó és munkatársai (2000) kimutatták, hogy a Vio de-epoxidáz enzim kapacitása a Conyza canadensis kétféle biotípusából izolált tilakoidokban azonos.

Számos gyomfaj AR biotípusa árnyékos nevelési környezetnek megfelelő levélanatómiai jelleget és kloroplasztisz ultrastruktúrát mutat, beleértve a nagyobb mértékü gránumosodást. A mutáció következtében a fotoszintetikus apparátus szerkezete is változik: a csökkent $\mathrm{Chl} a / b$ arányt és a fénybegyüjtő Chl-fehérje komplexek nagyobb mennyiségét írták le D1 fehérje mutáns növényekben (Burke et al., 1982; Holt \& Goffner, 1985; Lemoine et al., 1986). A Váradi és munkatársai (2003) által tanulmányozott valamennyi faj AR biotípusa következetesen alacsonyabb Chl $a / b$ aránnyal bírt a vad, atrazin-szenzitív (AS) típusokhoz képest. Ez jelezheti a PSII/PSI arány eltolódását és/vagy egy relatíve magasabb LHC antenna méretet, ez utóbbi pedig eredményezheti egy nagyobb mennyiségü többlet gerjesztési energia kialakulását a fotoszintetikus apparátusban (Váradi et al., 2003). Ez az árnyéklevél tulajdonság (Fedtke, 1979) a gyenge xantofill ciklus aktivitással együtt jól magyarázhatja néhány faj AR biotípusában a magas fényérzékenységet és a magas gerjesztési nyomást, különösen alacsony fényintenzitásokon (Váradi et al., 2003).

Habár az atrazin rezisztencia molekuláris bázisa az eddigi kutatások szerint a D1 protein egyetlen pontmutációján lokalizálódik, felmerül a kérdés, miként gyakorolhat ez ilyen összetett hatást a teljes növény szintjén. Miután a D1 protein egy kloroplasztiszban kódolt fehérje, az atrazin rezisztencia anyai úton öröklődik (Souza Machado et al., 1978). Ugyanazon az élőhelyen gyüjtött AR és AS növények is különbözhetnek egyes sejtmagban kódolt olyan tulajdonságokban, amelyek bizonyos fokig kompenzálhatják az atrazin rezisztenciát kísérő negatív fiziológiai következményeket (McCloskey \& Holt, 1990). Izonukleáris biotípusokkal - amelyek kizárólag az atrazin rezisztencia tulajdonságában különböznek - végzett kutatások eredményei azonban igazolták, hogy a megváltozott kloroplasztisz müködés az AR biotípusban az egész növény szintjén korlátozza a fotoszintézist, a növekedést és a produktivitást (McCloskey \& Holt, 1990; Beversdorf et al., 1988; Darmency \& Pernes, 1989; Gressel \& Ben-Sinai, 1985; Stowe \& Holt, 1988; van Oorschot \& Leeuwen, 1989). 


\section{CÉLKITÜZÉS}

A többlet gerjesztési energia fényindukált termális disszipációja fontos szerepet játszik a PSII antennarendszerében megvalósuló energia-áramlás szabályozásában. A termális disszipáció kapacitását a klorofill fluoreszcencia nem-fotokémiai kioltásaként (NPQ) határoztuk meg. Ismeretes, hogy az S264G D1 protein mutáns AR gyomnövények alacsonyabb NPQ és qE kapacitással rendelkeznek, mint vad-típusú AS párjaik (Váradi et al., 2003). Az NPQ kialakulásában ez idáig azonosított tényezők sejtmagi gének szabályozása alatt állnak. Nem világos, hogy a PSII reakció centrum D1 fehérjéje, amelyet a kloroplasztisz genomban a $p s b A$ gén kódol, milyen hatással van az antennában végbemenő hődisszipáció kialakulására. Ezért munkám során célul tüztem ki a következőket:

- Milyen kapcsolat van a D1 protein mutáció és a PSII antennájában elnyelt fényenergia allokációja között: a fotokémiai hasznosítás és a termális disszipáció?

- A klorofill $a$ fluoreszcencia analízis és a fotoprotektív folyamatok vizsgálata segítségével az alacsonyabb NPQ, illetve a qE komponens értelmezése a D1 protein mutáns növényekben.

- Ennek megválaszolására reciprok keresztezésekkel hibridek létrehozása, melyeken tanulmányozható a PSII allokációs mintázata, a qE és a gyors Chl fluoreszcencia paraméterek öröklődése; sejtmagi és citoplazmatikus (kloroplasztisz) faktorok szerepe a qE szabályozásában.

Ismeretes az atrazin-rezisztens növények eltérő hőmérséklet-érzékenysége és adaptációs képessége (Ducruet \& Lemoine, 1985), illetve fokozott fényérzékenységükröl egyaránt beszámoltak (Hart \& Stemler, 1990). Tudomásunk szerint a vízdeficit (szárazság) fotoszintézisre gyakorolt hatásait ez idáig nem vizsgálták még D1 protein mutáns növényekben. Kíváncsiak voltunk, vajon a vízdeficit befolyásolja-e a mutáns növények fitneszét. E kérdéskörben az alábbi célokat tüztem ki:

- A progresszív vízmegvonás hatásának megfigyelése intakt növények leveleinek vízállapotára, gázcseréjére és fotoszintetikus hatékonyságára. 


\section{ANYAG ÉS MÓDSZER}

\subsection{A vizsgált növényi anyag}

A kísérleti növényeim természetes körülmények között természetes módon szelektálódott vadtípusú, AS és D1 protein mutáns, AR Solanum nigrum L. (fekete csucsor) gyomnövények voltak. Az atrazin rezisztencia oka az általunk vizsgált gyomnövényben a psbA gén pontmutációja a 264-ik kodonban, amely a $\operatorname{Ser}_{264} \rightarrow$ Gly aminosavcserét eredményezi a D1 fehérjén. (Hirschberg \& McIntosh, 1983; Gawronski et al., 1992). A laboratóriumunkban elérhető különböző D1 protein mutáns gyomnövények (Chenopodium album L. (fehér libatop), Conyza canadensis L. (betyárkóró), Epilobium adenocaulon L. (jövevény füzike), Senecio vulgaris L. (közönséges aggófü) és Solanum nigrum L. (fekete csucsor)) közül azért esett a választásunk a fekete csucsorra, mert sikeresen nevelhető laboratóriumi körülmények között, viszonylag rövid az életciklusa, jól kezelhető levelei vannak a gázcseremérések szempontjából, valamint szülő vonalakból (AS és AR) hagyományos keresztezési eljárással laboratóriumi körülmények között sikeresen produkáltunk hibrideket.

Összehasonlító tanulmányokat végeztem továbbá két, csökkent NPQ-val rendelkező Arabidopsis thaliana L. (A. thaliana) mutáns vonal felhasználásával. Vad típusként a Columbia-0 ökotípust (Col-0) használtam. A két mutáns vonal az antiszensz lhcb2 és a psbS deléciós $n p q 4$-1 voltak. Míg az elöbbiben a kettes fénybegyüjtő pigment-fehérje komplexek (LHCII) fó alkotó elemei, az Lhcb1 és Lhcb2 fehérjék majdnem teljesen hiányoznak az Lhcb2 antiszensz konstrukció kifejeződése miatt (Ganeteg et al., 2001; Andersson et al., 2003; Ruban et al., 2003), az utóbbiban a $p s b S$ gén deléciója következtében a PsbS fehérje teljesen hiányzik (Li et al., 2000; 2002b).

\subsection{Növénynevelés, vízmegvonás}

A S. nigrum növények nevelésénél a magokat először petricsészébe helyeztük, amelyben nedves szürőpapíron, sötétben egy héten át csíráztak szobahőmérsékleten. A kicsírázott magokat kertészeti földbe helyeztük, majd a kikelt növényeket tenyészedényekbe ültettük át. A növényeket növénynevelö kamrákban neveltük, ahol a maximális fotoszintetikusan aktív 
radiáció értéke $350 \mu \mathrm{mol}$ foton $\mathrm{m}^{-2} \mathrm{~s}^{-1}$ volt $\left(16 \mathrm{~h}\right.$ fényperiódus, $25 / 20^{\circ} \mathrm{C}$ nappali/éjszakai hőmérséklet, kb. 50-60\%-os relatív páratartalom mellett). A növényeket kétnaponta öntöztük a kísérletek alatt, a 35-40 napos növényeket tekintettük jó vízellátású kontrollnak. A vetés utáni kb. 40-42. napon a növények egy részétől megvontuk az öntözést, és gázcsereméréseket végeztünk három-négy naponta, hogy a vízdeficit hatásait tanulmányozzuk. A növények vízállapotát és gázcseréjét jellemző paraméterek alapján három szakaszt különítettünk el a vízdeficit időbeni vizsgálata során: enyhe szárazság (5-7 nap vízmegvonást követően), közepes szárazság (13-15 nap), és erős szárazság (18-19 nap), melyeket DH1 (dehydration state 1), DH2 (dehydration state 2), és DH3 (dehydration state 3) jelöléssel illettük. A vízhiány egyes szakaszaiban a növények egy részét a rehidráció után 24 órával tovább vizsgáltuk, és RH1, RH2 vagy RH3 (rehydration sate 1, 2 és 3) jelöléssel illettük. A vízhiány periódusa alatt gázcsereméréseket a DH2 állapotig folytattunk, mivel a sztómazáródás következtében a DH3 szakaszban már a $\mathrm{CO}_{2}$ asszimilációs ráta értéke alacsonyabb volt, mint $1 \mu \mathrm{mol} \mathrm{m}^{-2} \mathrm{~s}^{-1}$. Méréseinket rendre a növények legfiatalabb, teljesen kiterült, azonos pozícióban lévő levelein végeztük.

$\mathrm{Az}$ A. thaliana növények magvait kertészeti földet tartalmazó tenyészedényekbe helyeztük, növénynevelö kamrákban csíráztattuk és neveltük, ahol a maximális fotoszintetikusan aktív radiáció értéke $350 \mu \mathrm{mol}$ foton $\mathrm{m}^{-2} \mathrm{~s}^{-1}$ volt $\left(16 \mathrm{~h}\right.$ fényperiódus, $25 / 20^{\circ} \mathrm{C}$ nappali/éjszakai hőmérséklet, $\mathrm{kb}$. 50-60\%-os relatív páratartalom mellett). Méréseinket rendre a kb. hat hetes növények legfiatalabb, teljesen kiterült levelein végeztük.

\subsection{Reciprok keresztezések kivitelezése, genetikai analízis}

Az AS és AR S. nigrum szülő biotípusok reciprok keresztezésével F1 hibrideket hoztunk létre. A levélszél típusát figyelmen kívül hagyva, véletlenszerüen kiválasztottunk 15 darab AS és 15 darab AR biotípusú növényt, melyek a női (ํ) szülőpopulációul szolgáltak. Hasonlóképpen, 15 darab AR és 15 darab AS növényegyedet választottunk hím (Ő) szülőpopulációul a reciprok keresztezésekhez. A 15-15 AS és AR anyaként szolgáló növényeken a bimbós állapotban lévő virágok éretlen portokjait eltávolítottuk, mielőtt az önmegporzás végbement volna, majd a vad-típusú AS (ठ) pollent az AR (†) növények bibéjére transzferáltuk, és az AR (Ô) növények pollenjét a vad-típusú, AS () növények bibéjére vittük át. A megporzást a 
növénynevelő kamrákban végeztük, ezzel kizárva a rovar általi megporzás lehetőségét. A sikeres megtermékenyítés aránya kb. 50\%-os volt; átlagosan 20 virág/növényt poroztunk meg, és ebböl kb. tíz darab virág termékenyült meg, majd hozott magot, kb. 20-25 mag/termés hozammal. Az első reciprok keresztezésből származó F1 hibrideket ARF1 és ASF1-nek definiáltuk. Miután e heterozigóta F1 növényekben megtörtént az önbeporzás (a $S$. nigrum önbeporzó), létrejöttek az F2 nemzedékü magok, melyeket ASF2 és ARF2-nek neveztünk. Az F2 növényeket használtuk a levélszél alak vizsgálathoz annak bizonyítására, hogy a mendeli levélszél tulajdonság szegregációja megtörtént-e. A szülő populációban három különböző levélszél típust találtunk, melyek Hardy-Weinberg eloszlást mutattak. A különböző levélszél típusok várható gyakoriságát a Hardy-Weinberg szabály alapján számoltuk ki. További keresztezéseket folytattunk, melyekben épszélü ASF2 (†) és csipkézett AR (O) szülőt vagy csipkézett ARF2 () és épszélủ AS (ठึ) szülőt használtunk, hogy létrehozzuk az F3 utódnövényeket (ASF3 és ARF3). Hasonlóan, épszélü ASF3 (†) és csipkézett AR (đ) szülőt vagy csipkézett ARF3 () és épszélü AS (ð) szülőt kereszteztünk, mellyel létrehoztuk az F4 hibrideket (ASF4 és ARF4), és így tovább az F6 nemzedékig. A S. nigrum szülö és hibrid vonalakban az S264G mutáció meglétét a $p s b A$ gén részleges megszekvenálásával bizonyítottuk. Valamennyi S. nigrum vonal esetében a csíranövényeket közvetlenül 8 kg aktív hatóanyag/hektár atrazinnal permeteztük, illetve felhasználva a mutáció jól ismert manifesztálódásait, vizsgáltuk a növények gyors Chla fluoreszcencia indukciós görbéit. Az F2 növényi anyag sejtmagi hibrid státuszát a teljesen kifejlődött levelek morfológiájának vizsgálatával igazoltuk.

\subsection{A növény vízellátásának vizsgálata}

\subsubsection{Sztómasürüség vizsgálata}

A gázcserenyílások számát a levelek abaxiális felületéről készült lenyomatok felhasználásával határoztuk meg $1 \mathrm{~mm}^{2}$-es felületen egy digitális CCD kamerával felszerelt reflexiós és fluoreszcencia mikroszkóp segítségével, amely egy komputerhez csatlakozott. A számolást a Computer Assisted Microscope Methods with Image-Pro Plus 3.0 Software segítségével végeztük el. Az átlagos sztómaszámot 116 növényről származó 116 levél vizsgálatával kaptuk 
meg biotípusonként, egy levélen belül hatszoros ismétléssel A növények három független növénynevelésböl származtak.

\subsubsection{A levelek relatív viztartalmának meghatározása}

A kontroll körülmények és a vízhiány szakaszainak jellemzésére meghatároztuk a levelek relatív víztartalmát (RWC) a következő képlet felhasználásával: $(\mathrm{FW}-\mathrm{DW}) / \mathrm{FW}_{\mathrm{S}}$, ahol az FW a levelek friss tömege, a DW a levelek száraz tömege 24 órán át $85^{\circ} \mathrm{C}$-on szárítószekrényben való szárítást követően, valamint az $\mathrm{FW}_{\mathrm{S}}$ a 24 órán keresztül vízben úsztatott levelek friss tömege grammban $[\mathrm{g}]$ kifejezve.

\subsubsection{A levélszövetek átlagos vízpotenciáljának mérése}

A levélszövetek átlagos vízpotenciálját nyomásmérő kamrával (Model 600, PMS Instruments Company, USA) határoztuk meg. Az eljárás során a frissen levágott levelet egy légmentesen záródó kamrába helyeztük úgy, hogy abból csak a vágott felület nyúlt ki. A kamrán belül lassan emeltük a nyomást (nitrogén felhasználásával) mindaddig, míg a kinyúló vágott felületen a növény szállítóelemeiből kipréselődő nedvesség csepp formájában meg nem jelent. Az ennek eléréséhez szükséges nyomást a kamrához kapcsolt nyomásmérőről olvastuk le.

\subsubsection{Sztóma konduktancia mérése}

A levelek abaxiális felületén a gázcserenyílások vezetőképességét a DELTA T müszergyártó cég (UK) AP4 típusú diffúziós porométerével határoztuk meg a növénynevelő kamrákban, ahol a körülmények a Növénynevelés, vízmegvonás fejezetben leírtak szerint alakultak. A sztómakonduktanciát az $\mathrm{A} / \mathrm{C}_{\mathrm{i}}$ görbék felvételekor szintén mértük az LCPro+ infravörös gázelemző készülékkel (IRGA; ADC, UK) (lásd: Gázcseremérések fejezet). 


\subsection{Elektron mikroszkópia}

A kloroplasztisz tilakoid struktúrájának vizsgálata transzmissziós elektron mikroszkópiával történt. A növények leveleiböl kis darabokat vágtunk ki, melyeket $1 \%$ glutáraldehidben fixáltunk két órán át. A minták foszfát pufferes $(0,1 \mathrm{M}, \mathrm{pH} 7,2)$ mosását követően 2\%-os ozmium tetroxidban egy órán át utófixáltuk öket. Ezután dehidratáltuk a levéldarabokat etanol gradiens sorozatain keresztül, majd propilénoxid mosás után, araldit gyantába ágyaztuk őket. Egy Leica UCT ultramicrotome segítségével vékony szekciókat vágtunk, melyeket uranil acetáttal és ólom citráttal festettünk meg. Az így kapott preparátumainkat egy Opton 902 elektron mikrószkóp segítségével tanulmányoztuk.

A levelek abaxiális felületének levélszőreit scanning elekron mikroszkópiával tanulmányoztuk. A vizsgálandó levéldarabkák víztelenítése céljából, azokat többlépcsős etanol-, majd aceton gradiens sorozaton vittük át, lépcsőnként 30-30 percig tartva a mintákat az oldatban. Végül a mintákat kritikus pont szárítóban háromszor átmostuk széndioxiddal. A víztelenített mintákat mintatartóra rögzítettük, majd aranyréteget vontunk a felületükre. Az elökészített minta felületéröl scanning elektron mikroszkóppal 60-szoros nagyítású fotókat készítettünk.

\subsection{Gázcseremérések}

\subsection{1. $\mathrm{CO}_{2}$ asszimilációs ráta meghatározása a fényintenzitás függvényében}

Az asszimilációs ráta (A) aktinikus fényre adott válaszgörbéit LCA-3 típusú infravörös gázelemző készülékkel (ADC, UK) vettük fel. A gázáramlás sebessége $300 \mathrm{ml}$ perc ${ }^{-1}$ volt, rotaméterrel szabályozott. A leveleket tíz percig sötétadaptáltuk a levélkamrában a mérések előtt, majd a fotoszintézist aktiváló fehér fény intenzitását 30-1250 $\mu \mathrm{mol}$ foton $\mathrm{m}^{-2} \mathrm{~s}^{-1}$ között változtattuk, a leveleket hőszürőn (Melles Griot, USA) keresztül diavetítővel $(150 \mathrm{~W} / 24 \mathrm{~V}$ halogén izzó) világítottuk meg. Tíz perces megvilágítás valamennyi fényintenzitáson elegendő volt a szén-dioxid asszimiláció egyensúlyi értékének eléréséhez. A referencia levegő széndioxid tartalmát $360 \mu \mathrm{mol} \mathrm{CO}_{2} \mathrm{~mol}^{-1}$-ra állítottuk be, és a levegő oxigéntartalma $21 \%$ 
vagy $1 \% \mathrm{v} / \mathrm{v}$ volt. Az asszimilációs ráta értékeit a müszer szofvere számította ki von Caemmerer és Farquhar (1981) egyenletei alapján.

\subsection{2. $\mathrm{CO}_{2}$ asszimilációs ráta meghatározása az intercelluláris $\mathrm{CO}_{2}$ koncentráció} függvényében

Az asszimilációs rátának az intercelluláris $\mathrm{CO}_{2}$ koncentrációtól $\left(\mathrm{C}_{\mathrm{i}}\right)$ való függését a környezeti $\mathrm{CO}_{2}$ koncentráció $\left(\mathrm{C}_{\mathrm{a}}\right) 0$ és $1500 \mu \mathrm{mol} \mathrm{CO} \mathrm{CO}^{-1}$ intervallum közötti változtatásával $21 \% \mathrm{O}_{2}$ tartalmú levegőben határoztuk meg LCpro+ IRGA készülékkel. A levél felületére beeső fotonáram-sürüséget $800 \mu \mathrm{mol}$ foton $\mathrm{m}^{-2} \mathrm{~s}^{-1}$-ra állítottuk be. Elöször $360 \mu \mathrm{mol} \mathrm{CO}_{2} \mathrm{~mol}^{-1}$ koncentráción akklimatizáltuk a megvilágított levelet tíz percen keresztül. Ezt követően az asszimiláció sebességét valamennyi $\mathrm{CO}_{2}$ koncentráción tíz perces inkubáció után határoztuk meg. Az adatokat ezután grafikusan ábrázoltuk a szoftver által számított intercelluláris $\mathrm{CO}_{2}$ koncentráció függvényében (Farquhar et al., 1990), és lineáris regresszióval meghatároztuk a görbék kezdeti meredekségét 0-200 $\mu \mathrm{mol} \mathrm{CO}_{2} \mathrm{~mol}^{-1}$ intervallumban, amely érték arányos a Rubisco enzim aktivitásával és/vagy extrahálható mennyiségével. $\mathrm{Az} A / \mathrm{C}_{\mathrm{i}}$ görbék további analízise során figyelembe vettük a $\mathrm{CO}_{2}$ asszimiláció telítési értékét $\left(\mathrm{J}_{\max }\right)$, amely tükrözi a RuBP regenerációjának maximális sebességét.

\subsection{Klorofill fluoreszcencia mérések}

\subsubsection{Gyors klorofill a fluoreszcencia indukció (OJIP görbe) mérése}

A gyors klorofill fluoreszcencia tranziens (OJIP görbe) méréseket a HandyPEA (Plant Efficiency Analyser) fotoszintetikus hatékonyságmérő készülékkel (Hansatech Instruments, UK) végeztük. A 30 percen át sötétadaptált leveleket folyamatos fénnyel $(\lambda=650 \mathrm{~nm}, 3000$ $\mu$ mol foton $\mathrm{m}^{-2} \mathrm{~s}^{-1}$ fotonáram-sürüség) $1 \mathrm{~s}$-ig világítottuk meg. A fényforrást egy három fénykibocsátó diódából (LED) álló rendszer alkotta. A fluoreszcenciát 700 nm-nél nagyobb hullámhosszakon detektáltuk nagy időfelbontásban és különböző adatgyüjtési sebesség mellett (10 $\mu$ s-tól $1 \mathrm{~s}$-ig). Az OJIP tranziensek további analízisét az ún. JIP-teszttel (Strasser et al., 2000; Tsimilli-Michael \& Strasser, 2008), illetve a Biolyzer 4HP szoftverrel végeztük. Az 1. 
táblázat tartalmazza a dolgozatomban fellelhető alap és származtatott fluoreszcencia paramétereket, a speciális energia fluxusok, hatásfokok, valamint az ún. fotoszintetikus teljesítmény indexek képleteit és ezek leírásait.

\section{1. táblázat Az OJIP klorofill a fluorszcencia tranziens analizise (paraméterek, képletek)}

\section{Fluoreszcencia paraméterek}

\begin{tabular}{|l|l|}
\hline$F_{\mathrm{t}}$ & $\begin{array}{l}\text { Fluoreszcencia intenzitás } \mathrm{t} \text { időpontban aktinikus megvilágítás } \\
\text { mellett } \\
\mathrm{F}_{\mathrm{o}}=\mathrm{F}_{20 \mu \mathrm{s}}\end{array}$ \\
$\mathrm{F}_{\mathrm{m}}=\mathrm{F}_{\mathrm{P}}$ & $\begin{array}{l}\text { Sötétadaptált minta alapfluoreszcencia intenzitása } \mathrm{t}=20 \mu \mathrm{s} \\
\text { időpillanatban (valamennyi PSII RC nyitott) } \\
\text { Sötétadaptált minta maximális fluoreszcencia intenzitása } \\
\text { (valamennyi PSII RC zárt) } \\
\text { Maximális változó fluoreszcencia }\end{array}$ \\
$\mathrm{F}_{\mathrm{v}}=\mathrm{F}_{\mathrm{m}}-\mathrm{F}_{\mathrm{o}}$ & Fluoreszcencia intenzitása a J inflexiónál $(\mathrm{t}=2 \mathrm{~ms})$ \\
$\mathrm{F}_{\mathrm{J}}=\mathrm{F}_{2 \mathrm{~ms}}$ & Fluoreszcencia intenzitása az I inflexiónál $(\mathrm{t}=30 \mathrm{~ms})$ \\
$\mathrm{F}_{\mathrm{I}}=\mathrm{F}_{30 \mathrm{~ms}}$ &
\end{tabular}

\section{Származtatott fluoreszcencia paraméterek}

\begin{tabular}{|l|l|}
\hline $\mathrm{V}_{\mathrm{J}}=\left(\mathrm{F}_{2 \mathrm{~ms}}-\mathrm{F}_{\mathrm{o}}\right) /\left(\mathrm{F}_{\mathrm{m}}-\mathrm{F}_{\mathrm{o}}\right)$ & $\begin{array}{l}\text { Relatív változó fluoreszcencia a J inflexiónál, mely tükrözi } \\
\text { mind a } \mathrm{Q}_{\mathrm{A}}^{-} \text {akkumulációjának, mind re-oxidációjának } \\
\text { sebességét }\end{array}$ \\
$\mathrm{V}_{\mathrm{I}}=\left(\mathrm{F}_{30 \mathrm{~ms}}-\mathrm{F}_{\mathrm{o}}\right) /\left(\mathrm{F}_{\mathrm{m}}-\mathrm{F}_{\mathrm{o}}\right)$ & $\begin{array}{l}\text { Relatív változó fluoreszcencia az I inflexiónál, mely a } \\
\text { plasztokinol }\left(\mathrm{PQH}_{2}\right) \text { re-oxidációjának sebességét tükrözi }\end{array}$ \\
$\mathrm{M}_{\mathrm{o}}=3,571 \times\left(\mathrm{F}_{300 \mu \mathrm{s}}-\mathrm{F}_{\mathrm{o}}\right) /\left(\mathrm{F}_{\mathrm{m}}-\mathrm{F}_{\mathrm{o}}\right)$ & $\begin{array}{l}\text { Fluoreszcencia tranziens } \mathrm{V}=\mathrm{f}(\mathrm{t}) \text { approximatív kezdeti } \\
\text { meredeksége }\left(\mathrm{ms}^{-1}\right), \text { a RC-k záródásának nettó sebessége; } \\
\left(3,571 \text { szorzót használtunk, mivel az } \mathrm{F}_{\mathrm{o}} \text { szintet } \mathrm{t}=20 \mu \mathrm{s} \text {-nál }\right. \\
\text { határoztuk meg } 50 \mu \text { selyett })\end{array}$ \\
\hline
\end{tabular}

\section{Specifikus energia fluxusok (* $\mathrm{Q}_{\mathrm{A}}$-redukáló) PSII reakciócentrumok arányában} kifejezve

\begin{tabular}{|l|l|}
\hline $\mathrm{ABS} / \mathrm{RC}=\mathrm{M}_{\mathrm{o}} \times\left(1 / \mathrm{V}_{\mathrm{J}}\right) \times\left(1 /\left(\mathrm{F}_{\mathrm{v}} / \mathrm{F}_{\mathrm{m}}\right)\right)$ & Abszorpciós fluxus per $\mathrm{RC}$ \\
$\mathrm{TR}_{\mathrm{o}} / \mathrm{RC}=\mathrm{M}_{\mathrm{o}} \times\left(1 / \mathrm{V}_{\mathrm{J}}\right)$ & Befogott energia fluxus $\left(\mathrm{Q}_{\mathrm{A}}\right.$ redukcióhoz vezető $)$ per $\mathrm{RC}$ \\
$\mathrm{ET}_{\mathrm{o}} / \mathrm{RC}=\mathrm{M}_{\mathrm{o}} \times\left(1 / \mathrm{V}_{\mathrm{J}}\right) \times\left(1-\mathrm{V}_{\mathrm{J}}\right)$ & Elektrontranszport fluxusa (a $\mathrm{Q}_{\mathrm{A}}^{-}$-on túlra definiált $)$per RC \\
$\mathrm{DI}_{\mathrm{o}} / \mathrm{RC}=(\mathrm{ABS} / \mathrm{RC})-\left(\mathrm{TR}_{\mathrm{o}} / \mathrm{RC}\right)$ & Disszipált energia fluxusa per RC \\
$\mathrm{RE}_{\mathrm{o}} / \mathrm{RC}=\left(\mathrm{RE}_{\mathrm{o}} / \mathrm{ET}_{\mathrm{o}}\right) \times\left(\mathrm{ET}_{\mathrm{o}} / \mathrm{RC}\right)$ & PSI végső elektron akceptor redukciójának fluxusa per RC
\end{tabular}

* $\mathrm{Q}_{\mathrm{A}}$-redukáló, fotokémiailag aktív PSII RC-kat megkülönböztetik stressz hatására konformáció változáson átment, $\mathrm{Q}_{\mathrm{A}}$-nem-redukáló, fotokémiailag nem aktív PSII RC-tól (lásd: Strasser et al., 2004). 


\section{1. táblázat (folytatás)}

\section{Hatásfokok és fluxus arányok}

\begin{tabular}{|c|c|}
\hline$\varphi_{\mathrm{Po}}=\mathrm{TR}_{\mathrm{o}} / \mathrm{ABS}=1-\left(\mathrm{F}_{\mathrm{o}} / \mathrm{F}_{\mathrm{m}}\right)=\mathrm{F}_{\mathrm{v}} / \mathrm{F}_{\mathrm{m}}$ & PSII primér fotokémiájának maximális hatásfoka \\
\hline $\begin{array}{l}\varphi_{\mathrm{Eo}}=\varphi_{\mathrm{Po}} \times \psi_{\mathrm{Eo}}=\mathrm{ET}_{\mathrm{o}} / \mathrm{ABS}=1-\left(\mathrm{F}_{\mathrm{J}} / \mathrm{F}_{\mathrm{m}}\right)= \\
\varphi_{\mathrm{Po}} \times\left(1-\mathrm{V}_{\mathrm{J}}\right)\end{array}$ & $\begin{array}{l}\text { Elektrontranszport hatásfoka a köztes elektron hordozók } \\
\text { irányában (azaz egy elnyelt foton milyen hatásfokkal } \\
\text { eredményez elektrontranszportot a } \mathrm{Q}_{\mathrm{A}}^{-}-\mathrm{n} \text { túl) }\end{array}$ \\
\hline $\begin{array}{l}\varphi_{\mathrm{Ro}}=\varphi_{\mathrm{Po}} \times \psi_{\mathrm{Eo}} \times \delta_{\mathrm{Ro}}=\mathrm{RE}_{\mathrm{o}} / \mathrm{ABS}=1- \\
\left(\mathrm{F}_{\mathrm{I}} / \mathrm{F}_{\mathrm{m}}\right)=\varphi_{\mathrm{Po}} \times\left(1-\mathrm{V}_{\mathrm{I}}\right)\end{array}$ & $\begin{array}{l}\text { A PSI végső elektron akceptorok redukciójának hatásfoka az } \\
\text { elnyelt fotonok arányában }\end{array}$ \\
\hline$\varphi_{\mathrm{Do}}=1-\varphi_{\mathrm{Po}}=\mathrm{DI}_{\mathrm{o}} / \mathrm{ABS}=\mathrm{F}_{\mathrm{o}} / \mathrm{F}_{\mathrm{m}}$ & Energia disszipáció hatásfoka \\
\hline$\psi_{\mathrm{Eo}}=\mathrm{ET}_{\mathrm{o}} / \mathrm{TR}_{\mathrm{o}}=\left(\mathrm{F}_{\mathrm{m}}-\mathrm{F}_{\mathrm{J}}\right) /\left(\mathrm{F}_{\mathrm{m}}-\mathrm{F}_{\mathrm{o}}\right)=1-\mathrm{V}_{\mathrm{J}}$ & $\begin{array}{l}\text { Annak a valószínüsége, hogy egy } \mathrm{RC} \text { által befogott exciton egy } \\
\text { elektront az elektrontranszportláncba juttat } \mathrm{a}_{\mathrm{A}^{-}}-\mathrm{n} \text { túl }\end{array}$ \\
\hline$\psi_{\mathrm{Ro}}=\mathrm{RE}_{\mathrm{o}} / \mathrm{TR}_{\mathrm{o}}=\psi_{\mathrm{Eo}} \times \delta_{\mathrm{Ro}}=1-\mathrm{V}_{\mathrm{I}}$ & $\begin{array}{l}\text { Annak a valószínüsége, hogy egy } \mathrm{RC} \text { által befogott exciton egy } \\
\text { elektront az elektrontranszportláncba juttat } \mathrm{a}_{\mathrm{A}}^{-} \text {felől a PSI } \\
\text { végső elektron akceptorokhoz }\end{array}$ \\
\hline $\begin{array}{l}\delta_{\mathrm{Ro}_{0}}=\mathrm{RE}_{\mathrm{o}} / \mathrm{ET}_{\mathrm{o}}=\left(\mathrm{F}_{\mathrm{m}}-\mathrm{F}_{\mathrm{I}}\right) /\left(\mathrm{F}_{\mathrm{m}}-\mathrm{F}_{\mathrm{J}}\right)=(1- \\
\left.\mathrm{V}_{\mathrm{I}}\right) /\left(1-\mathrm{V}_{\mathrm{J}}\right)\end{array}$ & $\begin{array}{l}\text { Annak a valószínüsége, hogy egy elektron a köztes elektron } \\
\text { akceptorok felől a PSI végső elektron akceptorokhoz jut }\end{array}$ \\
\hline
\end{tabular}

\section{Fotoszintetikus teljesítmény indexek}

$\mathrm{PI}_{\mathrm{abs}}=(\mathrm{RC} / \mathrm{ABS}) \times\left(\varphi_{\mathrm{Po}} /\left(1-\varphi_{\mathrm{Po}}\right)\right) \times\left(\psi_{\mathrm{Eo}} /(1\right.$
$\left.\left.-\psi_{\mathrm{Eo}}\right)\right)$
$\mathrm{PI}_{\text {total }}=\mathrm{PI}_{\mathrm{abs}} \times\left(\delta_{\mathrm{Ro}} /\left(1-\delta_{\mathrm{Ro}}\right)\right)$

A PSII által elnyelt fotonoktól a köztes elektron akceptorok redukciójáig tartó energia konverziót jellemző fotoszintetikus teljesítmény index (Performance Index, PI)

A PSII által elnyelt fotonoktól a PSI végső elektron akceptorokig tartó energia konverziót jellemző teljes fotoszintetikus teljesítmény index

\subsubsection{Modulációs klorofill a fluoreszcencia mérés, fotoprotektív folyamatok vizsgálata}

A Chl fluoreszcencia paraméterek steady-state szintjét 60 percig sötétadaptált leveleken a Dual Channel Modulated Fluorometer-rel (FMS2, Hansatech, UK) mértük; a van Kooten és Snel (1990) szerinti nómenklatúrát használtuk. A fluoreszcencia alapszintjét $\left(\mathrm{F}_{\mathrm{o}}\right)$ a 
sötétadaptált leveleken egy gyenge $(\lambda=583 \mathrm{~nm}) 4,8 \mathrm{kHz}$-en modulált fénnyel gerjesztettük. A levelek maximális fluoreszcenciáját $\left(\mathrm{F}_{\mathrm{m}}\right.$ a sötétadaptált és $\mathrm{F}_{\mathrm{m}}^{\prime}$ a fényadaptált levélben, utóbbinál $1600 \mu \mathrm{mol}$ foton $\mathrm{m}^{-2} \mathrm{~s}^{-1}$ aktinikus fénnyel 15 percen át világítottuk a levelet) $1 \mathrm{~s}$ időtartamú, fehér, telítési fényimpulzussal (4300 $\mu \mathrm{mol}$ foton $\left.\mathrm{m}^{-2} \mathrm{~s}^{-1}\right)$ indukáltuk (Hansatech PLS1 halogén lámpa). A PSII fotokémiájának optimális hatásfokát az $\mathrm{F}_{\mathrm{v}} / \mathrm{F}_{\mathrm{m}}$ formulával jellemeztük, ahol $\mathrm{F}_{\mathrm{v}}=\mathrm{F}_{\mathrm{m}}-\mathrm{F}_{\mathrm{o}}$. A Stern-Volmer nem-fotokémiai kioltási paramétert az NPQ = $\left(F_{m}-F_{m}^{\prime}\right) / F_{m}^{\prime}$ egyenlettel számoltuk ki Bilger és Björkman (1990) alapján. Az NPQ energiafüggő qE komponensét Thiele és munkatársai (1997) módszere szerint határoztuk meg a $\mathrm{qE}=\left(\mathrm{F}_{\mathrm{m}} / \mathrm{F}_{\mathrm{m}}^{\prime}\right)-\left(\mathrm{F}_{\mathrm{m}} / \mathrm{F}_{\mathrm{m}}{ }^{\prime}\right)$ alapján, ahol az $\mathrm{F}_{\mathrm{m}}{ }_{\mathrm{m}}$ a maximális fluoreszcencia szint az aktinikus fény kikapcsolását követő tíz perces sötétrelaxáció után.

A modulált Chl fluoreszcencia paraméterek aktinikus fényre adott válaszgörbéit és időfüggvény görbéit sötétadaptált leveleken mértük a PAM 200 (Teaching PAM, Walz, Németország) pulzus amplitudó modulált fluorométerrel; a van Kooten és Snel (1990) szerinti nómenklatúrát használtuk. A fényintenzitás-függés mérések esetén a 60 percig sötétadaptált levélen meghatároztuk a fluoreszcencia alapszintjét $\left(\mathrm{F}_{\mathrm{o}}\right)$ és a maximális fluoreszcencia hozamot $\left(\mathrm{F}_{\mathrm{m}}\right)$ egy $\quad 1 \quad \mathrm{~s}$ időtartamú $(\lambda \approx 650 \quad \mathrm{~nm})$ telítési fényimpulzussal $\quad(3000$ $\mu \mathrm{mol}$ foton $\mathrm{m}^{-2} \mathrm{~s}^{-1}$ ) (mely elegendő valamennyi PSII RC záródásához). Ezt követően öt percen keresztül $210 \mu \mathrm{mol}$ foton $\mathrm{m}^{-2} \mathrm{~s}^{-1}$ aktinikus fénnyel történő előmegvilágítást alkalmaztunk, mely elősegítette a minta fényadaptálódását, valamint néhány Calvin-ciklus enzim aktivációját, majd elkezdődött a görbe fevétele, mely 60-1250 $\mu \mathrm{mol}$ foton $\mathrm{m}^{-2} \mathrm{~s}^{-1}$ intervallumban, tíz lépcsőben valósult meg; valamennyi fényintenzitás időtartama öt perc volt. A maximális Chl fluoreszcencia paraméter kioltott szintjeit ( $\left.F_{m}^{\prime}\right)$ és a steady-state fluoreszcencia hozamokat $(F)$ valamennyi fényintenzitáson meghatároztuk a megvilágítás végén. Az egyes fényintenzitásokon az aktinikus fény kikapcsolása után $5 \mathrm{~s}$ időtartamú távoli vörös fényt alkalmaztunk, hogy meghatározzuk az $\mathrm{F}_{\mathrm{o}}$ o értékeket. A mért paraméterekből ( $\mathrm{F}_{\mathrm{o}}$, $\mathrm{F}_{\mathrm{m}}, \mathrm{F}_{\mathrm{o}}^{\prime}, \mathrm{F}_{\mathrm{m}}^{\prime}$ és a steady-state fluoreszcencia szint, F) kiszámítottuk a PSII maximális hatásfokát $F_{v} / F_{m}$ sötétadaptált levélen, a fotokémiai kioltási koefficiens értékét $q P=\left(F_{m}^{\prime}-F\right) /\left(F_{m}^{\prime}-F_{o}{ }_{o}\right)$, a PSII RC-ra ható gerjesztési nyomást 1 - qP, a PSII fotokémiájának relatív hatásfokát $\left(\Phi_{\mathrm{PSII}}=\right.$ $\left.\left(F_{m}^{\prime}-F\right) / F_{m}^{\prime}=\Delta F^{\prime} F_{m}^{\prime}\right)$ és a nem-fotokémiai kioltási paraméter $N P Q=\left(F_{m}-F_{m}^{\prime}\right) / F_{m}^{\prime}$ értékét Schreiber és munkatársai (1986), Genty és munkatársai (1989), Bilger és Björkman (1990) szerint. A PSII-n keresztüli lineáris elektrontranszport sebességének kiszámításához $\left(\mathrm{J}_{\mathrm{ETR}}\right)$ a 
következő egyenlet alapján jutottunk: $\mathrm{J}_{\mathrm{ETR}}=\Phi_{\mathrm{PSII}} \times \mathrm{PPFD} \times 0,84 \times 0,5($ Schreiber et al., 1994), ahol a PPFD a fotoszintetikusan aktív foton denzitás (Photosynthetically Active Photon Flux Density) a levélfelületen; a 0,5 faktor a két fotoszisztéma között feltételezhetően egyenlően megoszló gerjesztésre utal, és a 0,84 faktor a beeső fény levél által elnyelt hányada. A mérések során a PSII gerjesztéséhez vörös $\left(\lambda_{\max }=655 \mathrm{~nm}\right)$ aktinikus fényt használtunk.

Az NPQ indukcióját és sötétrelaxációját két órán át sötétadaptált leveleken határoztuk meg. A leveleket 15 percen keresztül $1250 \mu \mathrm{mol}$ foton $\mathrm{m}^{-2} \mathrm{~s}^{-1}$ vörös fénnyel világítottuk meg, amelyet tíz perces sötét követett. Az első $1 \mathrm{~s}$ időtartamú $3000 \mu \mathrm{mol}$ foton $\mathrm{m}^{-2} \mathrm{~s}^{-1}$ fényintenzitású telítési impulzus a megvilágítás kezdete után a tizedik másodpercben érkezett, és 60 s-ként ismétlödött a mérés végéig.

\subsubsection{A PSII-ben elnyelt fényenergia megoszlásának vizsgálata}

A PAM 200 készülékkel mért Chl fluoreszcencia paramétereket $\left(F_{0}, F_{m}, F_{o}^{\prime}, F_{m}^{\prime}\right.$ és $\left.F\right)$ felhasználva két modell alapján meghatároztuk a PSII antennájában elnyelt fényenergia sorsát, mely egyrészt fotokémiailag hasznosulhat, másrészt termálisan disszipálódhat a környezetbe.

Demmig-Adams és munkatársai (1996) modellje szerint a fotokémia által hasznosuló energia frakciót a $\Phi_{\mathrm{PSII}}=\left(\mathrm{F}_{\mathrm{v}} / \mathrm{F}_{\mathrm{m}}^{\prime}\right) \times \mathrm{qP}$ formulával definiáltuk, ahol az $\mathrm{F}_{\mathrm{v}}^{\prime} / \mathrm{F}_{\mathrm{m}}$ a nyitott PSII RC-ok fotokémiájának hatásfoka $\left(F_{\mathrm{v}}^{\prime}=F_{m}^{\prime}-F_{o}^{\prime}\right)$ és a $\mathrm{qP}=\left(F_{m}^{\prime}-F\right) /\left(F_{m}^{\prime}-F_{o}^{\prime}\right)$ a fotokémiai kioltási koefficiens. A hődisszipációt az $1-\mathrm{F}_{\mathrm{v}}{ }_{\mathrm{v}} / \mathrm{F}_{\mathrm{m}}{ }_{\mathrm{m}}$ képlettel definiáltuk, mely felosztható a sötétben bekövetkező energiaveszteség $\Phi_{\mathrm{DD}}=1-\mathrm{F}_{\mathrm{v}} / \mathrm{F}_{\mathrm{m}}$ és a fényben disszipálódó hőenergia frakcióira $\Phi_{\mathrm{DL}}=\mathrm{F}_{\mathrm{v}} / \mathrm{F}_{\mathrm{m}}-\mathrm{F}_{\mathrm{v}}^{\prime} / \mathrm{F}_{\mathrm{m}}^{\prime}$. A többlet energia frakciót $\left(\Phi_{\mathrm{E}}\right)$, amely nem hasznosul a fotokémia folyamán, és hőként sem disszipálódik, az $\left(\mathrm{F}_{\mathrm{v}}{ }_{\mathrm{V}} \mathrm{F}_{\mathrm{m}}\right) \times(1-\mathrm{qP})$ képlettel számoltuk ki.

A Hendrickson és munkatársai (2004) által leírt ún. PSII komplementer hatásfokok koncepciója szerint a PSII fotokémiájának hatásfoka a $\Phi_{\mathrm{PSII}}=\left(\mathrm{F}_{\mathrm{m}}^{\prime}-\mathrm{F}\right) / \mathrm{F}_{\mathrm{m}}^{\prime}=\Delta \mathrm{F} / \mathrm{F}_{\mathrm{m}}$ egyenlet alapján számolható. A nem-fotokémiai energia disszipáció regulált és nem-regulált módon mehet végbe, és ezeket a $\Phi_{\mathrm{NPQ}}=\left(\mathrm{F} / \mathrm{F}_{\mathrm{m}}^{\prime}\right)-\left(\mathrm{F} / \mathrm{F}_{\mathrm{m}}\right)$ és $\Phi_{\mathrm{NO}}=\mathrm{F} / \mathrm{F}_{\mathrm{m}}$ képletekkel határoztuk meg. A $J_{\mathrm{NPQ}}$ és a $\mathrm{J}_{\mathrm{NO}}$ energia disszipáció sebességeket a $\mathrm{J}_{\mathrm{ETR}}$ meghatározásával azonos módon becsültük meg. 


\subsection{Fotoszintetikus pigmenttartalom meghatározás}

A HPLC és spektrofotometriás pigment meghatározás céljából korongokat vágtunk ki a levelek azonos részeiből, és folyékony nitrogénben tároltuk azokat. A Chl és összkarotinoid tartalom meghatározását 80\%-os acetonos extraktumban Lichtenthaler (1987) spekrofotomeriás módszere alapján végeztük. A HPLC analízis kivitelezése Váradi és munkatársai (2003) módszere szerint történt. A pigmentek feltárását Eppendorf csövekben, cseppfolyós nitrogénben történt mechanikai feltárást követően, 85:15 arányú aceton-víz extraháló oldattal végeztük, 24 órára hütőszekrénybe helyezve, majd az elegyet centrifugálva (10 perc, $9000 \times \mathrm{g})$. A xantofill ciklus összkészletének meghatározásához a szilárd maradékot acetonnal kétszer újra extraháltuk. A pigmentek szétválasztásához $5 \mu \mathrm{m}$ átlagos szemcseméretü, 25 cm-es C18 fordított fázisú (Nucleosil vagy Hypersil) oszlopon (A) acetonitril-víz $(9: 1, \mathrm{v} / \mathrm{v})$ - (B) etilacetát oldószerrendszerrel gradiens elúciót alkalmaztunk

(térfogatáram: $1 \mathrm{ml} \mathrm{min}{ }^{-1}$; a $\mathrm{B} \%(\mathrm{v} / \mathrm{v})$ az injektálástól mért 18. percben zérusról indulva lineáris felfutással elérte a 32\%-ot, majd hat perc alatt a 100\%-ot, s újabb hat percig ezt az értéket tartotta, ezt követően pedig tíz percen át az A-eluenssel hoztuk egyensúlyba az oszlopot). A xantofill ciklus pigmentek mennyiségét $450 \mathrm{~nm}$-nél detektáltuk, standard anyagként a Roĉhe (Svájc) cégtől származó tiszta zeaxantin szolgált. A kapott kromatogramok integrálása után, a meghatározott területek alapján kiszámoltuk a violaxantin (Vio), anteraxantin (Ant) és zeaxantin (Zea) mennyiségét, vagy \%-os megoszlását. A xantofill ciklus komponenseinek egymásba való átalakulását a xantofill ciklus pigmentek de-epoxidációs állapotával DEi $=[1 / 2 \times$ Ant + Zea $] /[$ Vio + Ant + Zea $]$ jellemeztük. A xantofill ciklus készletének méretét a Vio + Ant + Zea $\left(\mu \mathrm{mol} \mathrm{m} \mathrm{m}^{-2}\right)$ összmennyiségeként számítottuk ki. A méréseket kezdetben LKB 2249 gradiens pumpa, $20 \mu$ l-es Rheodyne injektor, Nucleosil-100 C18/5 $\mu \mathrm{m} / 250 \times 4,6 \mathrm{~mm}$ oszlop, LKB $2151 \mathrm{UV} / \mathrm{VIS}$ detektor (450 nm), Nelson interface \& software/IBM XT összeállítású müszersoron, későbbiekben hüthető automata mintaváltóval felszerelt, PC-vezérelt Perkin-Elmer Series 200 HPLC berendezésen végeztük. 


\subsection{DNS izolálás és PCR amplifikáció, PsbS és PsbA (D1) fehérjéket kódoló DNS szakaszok szekvenálása}

Négy hetes $S$. nigrum vonalak leveleiböl ZenoGene Plant DNA Isolation Kit (Zenon Biotechnológiai kft., Magyarország) felhasználásával növényi össz-DNS-t izoláltunk a gyártó utasításai szerint. A $p s b S$ és a $p s b A$ gének PCR amplifikációjához 50 ng DNS-t használtunk templátként. Három $p s b S$-specifikus primer pár (2. táblázat) segítségével $\sim 600$ bp, 1360 bp és $\sim 159$ bp átfedő fragmenteket szaporítottunk fel a két $S$. nigrum szülői vonalból. A SniD1 primerekkel (2. táblázat) a D1 protein mutáns (AR, ARF2, ARF6) és a vad-típusú (AS, ASF2, ASF6) vonalakban felszaporíttattuk a psbA gén 386 bp-os DNS fragmentjét, mely tartalmazta az A $\rightarrow$ G nukleotid cserét (S264G mutáció). A PCR ciklusok a következők voltak: denaturáció $94^{\circ} \mathrm{C} 3$ perc, azután $94^{\circ} \mathrm{C} 30 \mathrm{~s}, 60^{\circ} \mathrm{C} 30 \mathrm{~s}, 72^{\circ} \mathrm{C} 15-60 \mathrm{~s} 35$ cikluson át, majd a reakciót egy 4 perces $72^{\circ} \mathrm{C}$-os lépéssel fejeztük be. Az amplifikáció termékeit 2\%-os agaróz gélben választottuk el, majd a fragmenteket visszaizoláltuk az Agarose DNA Isolation Kit segítségével (Zenon Biotechnológiai kft., Magyarország) és pGEM-T Easy vektorba (Promega Corp., USA) klónoztuk a gyártó utasításainak megfelelően. A szekvenálási reakciót ABI BigDye Terminator v3.1 kittel végeztük, és a termékeket ABI3100 mikrokapilláris lézer szekvenátoron futattuk (Applied Biosystems Inc., USA).

2. táblázat A psbS és a psbA gének PCR amplifikációjához használt primer szekvenciák

\begin{tabular}{|l|l|}
\hline Primer & Primer szekvencia \\
\hline Pr-SniF1 & 5'-TGAAGTTGTTAAGAATAAGC-3' \\
\hline Pr-SniR1 & 5'-TCATTATTCTATTAAAGGCT-3' \\
\hline Pr-SniF2 & 5'-GGCCGTGTTGCTATGATT-3' \\
\hline Pr-SniR2 & 5'-TAATCCTGGTACTGGCAAAT-3' \\
\hline Pr-SniStop-F1 & 5'-CAGGTGTCCCAATCAAT-3' \\
\hline Pr-SniStop-R1 & 5'-CTACACATAAGTCATACACA-3' \\
\hline SniD1_F1 & 5'-CCCAATCGGTCAAGGAAGTTTTT-3' \\
\hline SniD1_R1 & 5'-CAGGCCAAGCAGCTAGGAAGAAGT-3' \\
\hline
\end{tabular}




\subsection{Immunoblot analízis}

A levelek PsbA (D1) és PsbS fehérje tartalmait immunoblot analízissel határoztuk meg. 2,3

$\mathrm{cm}^{2}$-nek megfelelő területü korongokat vágtunk ki az AS és az AR S. nigrum leveleiből, melyeket folyékony nitrogénben fagyasztottunk, majd finom porrá öröltünk, és $500 \mu 1$ Laemmli puffer (100 mM TRIS pH 6,8, 4\% SDS, 10\% glicerol, 200 mM DTT, 5 mM PMSF) hozzáadásával elhomogenizáltunk. A homogenizátumokat $90^{\circ} \mathrm{C}$-on öt percig inkubáltuk, amelyet egy 20 perces $37^{\circ} \mathrm{C}$-os inkubáció követett, majd a fehérjéket SDS-poliakril-amid gélelektroforézissel (Laemmli, 1970) választottuk el 1 mm vastag, 15\%-os gélen 37,5:1 akrilamid:biszakrilamid arány mellett. Minden egyes zsebbe $5 \mu$ mintát vittünk fel.

Az elválasztott fehérjéket nitrocellulóz membránra (Protran, Schleicher \& Schuell) blottoltuk át metanol tartalmú pufferrel (25 mM TRIS, $192 \mathrm{mM}$ glicin, 20\% metanol). A nitrocellulóz membránokat 5\%-os tejport tartalmazó TBS-T pufferben (10 mM TRIS pH 8,0, $0,15 \mathrm{M} \mathrm{NaCl}, 0,1 \%$ Tween 20) két órán át blokkoltuk, és két órán keresztül inkubáltuk PsbA és PsbS (Agrisera) fehérjék elleni elsődleges antitestekkel, melyeket 5\% tejport tartalmazó TBS-T pufferben hígítottunk ki (1:6000 és 1:3000 arányban). A membránokat háromszor öt percig mostuk TBS-T pufferben és kecskéből származó anti-nyúl IgG torma peroxidázzal (HRP) konjugált másodlagos ellenanyaggal (Millipore) két órán át inkubáltuk 1:5000 hígítási arányban 5\% tejport tartalmazó TBS-T pufferben. Háromszor öt perces TBS-T pufferrel történő mosás után az immunoblottolt membánokat öt percen át inkubáltuk ECL plus HRP szubsztrátban (GE Healthcare Bio-Sciences) és a kemilumineszcenciát Hyperfilm ECL fotografikus filmen (GE Healthcare Bio-Sciences) detektáltuk. Az előhívott filmet digitalizáltuk és 1D Scan programcsomag segítségével analizáltuk.

\subsection{Statisztikai analízis}

A vizsgálati eredmények statisztikai feldolgozásához és kiértékeléséhez a Student t-tesztet használtuk, a gyakorisági eloszlások hasonlóságát $\chi^{2}$ próbával ellenőriztük. A dolgozatban a szignifikáns eltéréseket különböző tévedési valószínüségi szinteken jelöltük ( $\mathrm{a}, \mathrm{b}$ és c $0,1,1$ és $5 \%$ ). 


\section{EREDMÉNYEK}

\subsection{Az elnyelt fényenergia hasznosításának összehasonlító vizsgálata a $S$. nigrum kétféle biotípusában és a különböző növénynemzedékekben}

Egy anyai öröklődésű faktor, a D1 fehérje hatásának vizsgálata céljából a S. nigrum AS és AR szülő biotípusai között reciprok keresztezéseket végeztünk az F6 nemzedékig. Az így nyert izonukleáris növényvonalak fotoszintetikus jellemzése mellett vizsgáltuk a D1 fehérje S264G mutációjának hatását az elnyelt fényenergia sorsára. A keresztezések sikerességét, vagyis a különböző vonalak sejtmagi hibridstátuszának meglétét egy mendeli tulajdonság öröklödésének nyomonkövetésével bizonyítottuk.

\subsubsection{A S. nigrum biotípusok és vonalak fotoszintetikus jellemzése}

A 3. táblázatban a $S$. nigrum vonalak néhány állandósult (steady-state) fotoszintetikus paraméterét mutatom be. Az infravörös gázelemző segítségével meghatározott maximális asszimilációs ráták $\left(\mathrm{A}_{\max }\right)$ közel azonosak voltak az AS és AR szülő biotípusokban, valamint ezek reciprok keresztezéseiből való F1 és F2 hibridekben is. Valamennyi AR vonal (AR, ARF1, ARF2) sötétadaptált leveleiben a PSII maximális hatásfoka $\left(\mathrm{F}_{\mathrm{v}} / \mathrm{F}_{\mathrm{m}}\right)$ alacsonyabbnak bizonyult, mint a vad típusokban (AS, ASF1, ASF2). Szignifikáns különbségek adódtak az NPQ és a qE kioltási koefficiens értékeiben nemcsak a szülöi AS és AR biotípusok között, hanem ezek F1 és F2 utódaiban is (Student t-teszt). Az anyától örökölt vad fenotípusú/genotípusú (AS, ASF1, ASF2) vonalakban a steady-state NPQ szintje elérte a kb. 2,6 értéket, ezzel szemben valamennyi AR vonalban (AR, ARF1, ARF2) az NPQ kb. 50\%-kal alacsonyabb volt (4. táblázat). Az NPQ gyorsan relaxálódó komponense, a $\Delta \mathrm{pH}$-függő qE, még kifejezettebb, 60-70\%-os esést mutatott az AR vonalakban a vad típusokhoz képest. A lassan relaxálódó vagy qI értékek viszont megnőttek az AR vonalakban a qE rovására.

Az alkalmazott nevelési körülmények között az AR vonalak kissé alacsonyabb összes Chl $(a+b)$ tartalmakkal bírtak, és szignifikánsan alacsonyabb Chl $a / b$ arányokkal, mint az AS párjaik (4. táblázat). Azonban nem találtunk szignifikáns eltéréseket az AS és AR típusokban a karotinoid összetétel, a xantofill ciklus készlet méret, vagy a xantofill ciklus készlet méret és 
Chl tartalom aránya tekintetében. A megvilágított levelekben a xantofill de-epoxidációs index (DEi) 20\%-kal bizonyult alacsonyabbnak valamennyi AR vonalban (3. táblázat), habár a különböző $S$. nigrum vonalak xantofill ciklus készlet méretében nem volt szignifikáns eltérés.

3. táblázat A különbözö S. nigrum vonalak fotoszintetikus tulajdonságai

\begin{tabular}{|c|c|c|c|c|c|c|}
\hline \multirow{2}{*}{ Paraméter } & \multicolumn{6}{|c|}{ Biotípus } \\
\hline & AS & AR & ASF1 & ARF1 & ASF2 & ARF2 \\
\hline$A_{\max }\left(\mu \mathrm{mol} \mathrm{m}{ }^{-2} \mathrm{~s}^{-1}\right)$ & $18,4 \pm 1,4$ & $17,5 \pm 1,7$ & $17,8 \pm 1,6$ & $17,9 \pm 1,5$ & $18,1 \pm 1,2$ & $17,8 \pm 1,4$ \\
\hline $\mathrm{F}_{\mathrm{v}} / \mathrm{F}_{\mathrm{m}}$ & $0,830 \pm 0,014$ & $0,815 \pm 0,015$ & $0,824 \pm 0,012$ & $0,809 \pm 0,019$ & $0,825 \pm 0,010$ & $0,811 \pm 0,012$ \\
\hline NPQ & $2,53 \pm 0,21$ & $1,32 \pm 0,19^{a}$ & $2,65 \pm 0,22$ & $1,24 \pm 0,15^{a}$ & $2,59 \pm 0,18$ & $1,33 \pm 0,21^{a}$ \\
\hline $\mathrm{qE}$ & $2,18 \pm 0,12$ & $0,72 \pm 0,14^{\mathrm{a}}$ & $2,24 \pm 0,16$ & $0,75 \pm 0,17^{\mathrm{a}}$ & $2,28 \pm 0,20$ & $0,81 \pm 0,25^{a}$ \\
\hline ql & $0,35 \pm 0,03$ & $0,60 \pm 0,10^{c}$ & $0,41 \pm 0,04$ & $0,49 \pm 0,06$ & $0,31 \pm 0,04$ & $0,52 \pm 0,16$ \\
\hline $\mathrm{DEi}$ & $0,67 \pm 0,01$ & $0,53 \pm 0,02^{\mathrm{a}}$ & $0,67 \pm 0,02$ & $0,55 \pm 0,03^{a}$ & $0,65 \pm 0,02$ & $0,52 \pm 0,02^{a}$ \\
\hline
\end{tabular}

$A S$, vad biotípus; AR, D1 mutáns; ASF1 és ARF1, a szülői AS és AR biotipusok reciprok keresztezésiböl való F1 hibridek; ASF2 és ARF2, F2 hibridek; $A_{\text {max }}$, maximális asszimilációs ráta $\left(\mu \mathrm{mol} \mathrm{m} \mathrm{m}^{-1}\right) ; F_{v} / F_{m}$, PSII maximális hatásfoka; NPQ, steady-state nem-fotokémiai kioltás (1600 $\mu \mathrm{mol}$ foton $\mathrm{m}^{-2} \mathrm{~s}^{-1}, 15$ perc); qE, az NPQ gyorsan relaxálódó komponense; qI, az $N P Q$ lassan relaxálódó komponense; $D E i$, a xantofill pigmentek steady-state de-epoxidációs indexe $(1 / 2 \times$ Ant + Zea $) /($ Vio + Ant + Zea $)$. Az adatok három független kísérletböl 12 ismétlés átlagai $\pm S D$. Az “a és c” szignifikáns eltérést jelölik a kétféle biotipus között 0,1 és 5\%-os tévedési valószínüségi szinten.

4. táblázat A különbözö S. nigrum vonalak pigment összetétele

\begin{tabular}{lcccccc}
\hline \multirow{2}{*}{ Pigment } & \multicolumn{5}{c}{ Biotípus } \\
\cline { 2 - 6 } & AS & AR & ASF1 & ARF1 & ASF2 & ARF2 \\
\cline { 2 - 6 } Chl $a\left(\mu \mathrm{mol} \mathrm{m}^{-2}\right)$ & $212 \pm 8$ & $191 \pm 5$ & $220 \pm 8$ & $181 \pm 8$ & $216 \pm 5$ & $194 \pm 3$ \\
Chl $\left.b(\mu \mathrm{mol} \mathrm{m})^{-2}\right)$ & $67 \pm 4$ & $71 \pm 3$ & $70 \pm 4$ & $76 \pm 2$ & $69 \pm 4$ & $71 \pm 4$ \\
Chl $a / b$ & $3,17 \pm 0,02$ & $2,71 \pm 0,04^{\mathrm{a}}$ & $3,12 \pm 0,03$ & $2,36 \pm 0,06^{\mathrm{a}}$ & $3,14 \pm 0,02$ & $2,72 \pm 0,03^{\mathrm{a}}$ \\
Karotinoidok $\left(\mu \mathrm{mol} \mathrm{m}^{-2}\right)$ & $83 \pm 2$ & $78 \pm 2$ & $86 \pm 4$ & $82 \pm 2$ & $83 \pm 3$ & $81 \pm 2$ \\
Chl $(a+b) /$ Karotinoidok & $3,36 \pm 0,2$ & $3,36 \pm 0,2$ & $3,37 \pm 0,1$ & $3,13 \pm 0,2$ & $3,43 \pm 0,2$ & $3,27 \pm 0,2$ \\
Vio+Ant+Zea $\left(\mu \mathrm{mol} \mathrm{m}^{-2}\right)$ & $15,7 \pm 1,4$ & $14,4 \pm 1,7$ & $15,6 \pm 1,9$ & $14,6 \pm 1,0$ & $15,6 \pm 0,5$ & $14,9 \pm 1,2$ \\
$($ Vio+Ant+Zea $) /(\mathrm{Chl}(\mathrm{a}+b))\left(\mu \mathrm{mol} \mathrm{mmol}^{-1}\right)$ & $56 \pm 3$ & $54 \pm 3$ & $54 \pm 4$ & $57 \pm 5$ & $55 \pm 2$ & $56 \pm 4$ \\
\hline
\end{tabular}

Az adatok három független kísérletböl öt ismétlés átlagai $\pm S D$. Az “a” szignifikáns eltérést jelöli a két biotípus között 0,1\%-os tévedési valószínüségi szinten 
A 5. ábrán a különböző $S$. nigrum vonalakban néhány fluoreszcencia kioltási paraméter fényintenzitás függésének összehasonlítását mutatom be: $(a)$ a PSII fotokémiájának hatásfoka $\left(\Phi_{\mathrm{PSII}}\right) ;(b)$ a lineáris elektrontranszport ráta $\left(\mathrm{J}_{\mathrm{ETR}}\right)$; és $(c)$ a PSII-re ható gerjesztési nyomás (1 - qP). Az emelkedő fényintenzitással a $\Phi_{\text {PSII }}$ fokozatosan csökkent, míg a $\mathrm{J}_{\mathrm{ETR}}$ és az 1 - qP növekedett valamennyi biotípusban és vonalban. A $\Phi_{\text {PSII }}$ és a $J_{\mathrm{ETR}}$ (5. a és b ábrák) szignifikánsan alacsonyabb értékeket vettek fel a növekvő fényintenzitásokkal az AR vonalakban, mint a vad, AS típusokban. Az AR vonalakban a PSII-re ható gerjesztési nyomás (5. c ábra), ezáltal a redukált $\mathrm{Q}_{\mathrm{A}}$ koncentrációja, szignifikánsan magasabb volt a közepes és a magas fényintenzitásokon, mint az AS párjaikban $(\mathrm{p}=0,01)$.

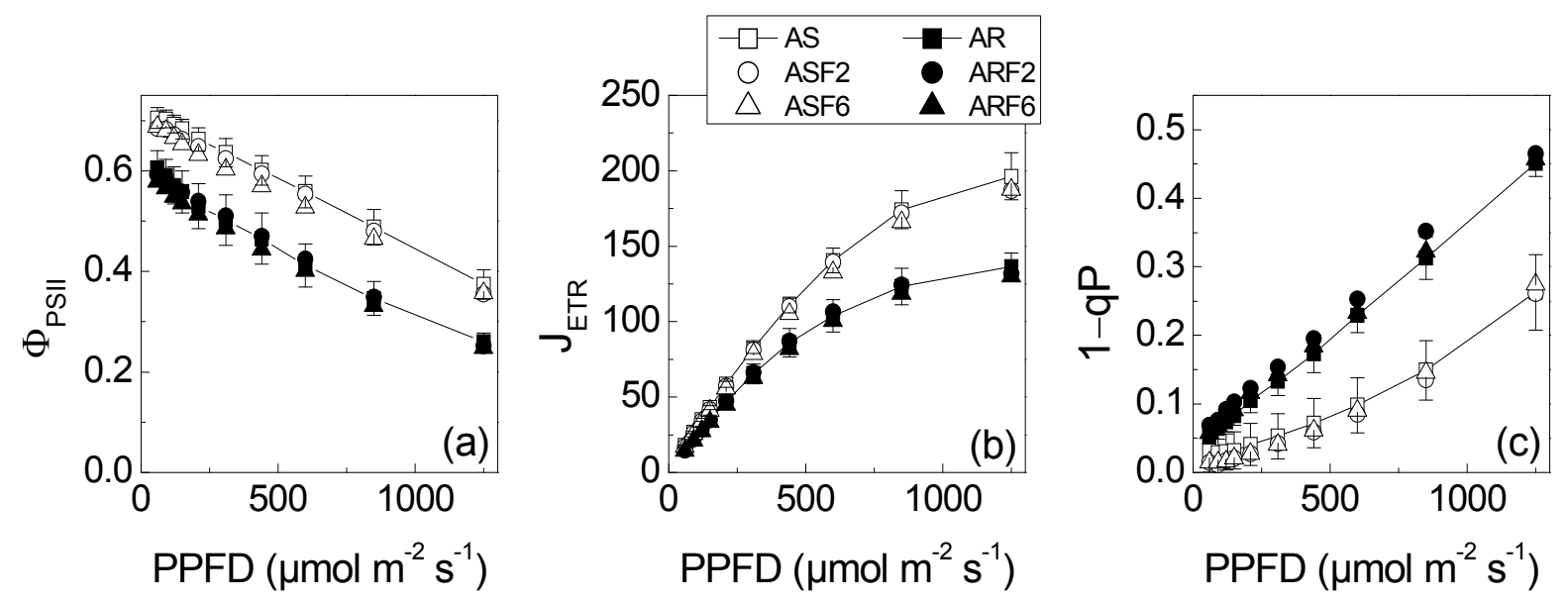

5. ábra A PSII fotokémiájának hatásfoka $\left(\Phi_{P S I}, a\right)$, a lineáris elektrontranszport ráta $\left(J_{E T R}, b\right)$ és a PSII-re ható gerjesztési nyomás $(1-q P$, c) fényintenzitás függése a vad-típusú $(A S, A S F 2$, ASF6) és a D1 mutáns (AR, ARF2, ARF6) S. nigrum vonalakban. AS és AR, szülö, - $\square-$ és - ; ASF2 és ARF2, $\bigcirc$ és O; ASF6 és ARF6, $\triangle$ és $\boldsymbol{\Delta}$. Az adatok három független kísérletből 12 ismétlés átlagai. A SD a szülö (AS és AR) populációkban van feltüntetve.

A S. nigrum növények mért és a relatív változó $\left(\mathrm{F}_{\mathrm{t}}-\mathrm{F}_{\mathrm{o}}\right) /\left(\mathrm{F}_{\mathrm{m}}-\mathrm{F}_{\mathrm{o}}\right)$ Chl fluoreszcencia tranzienseinek átlagértékei a 6. a és b ábrákon láthatók. Megállapíthatjuk, hogy mindkét biotípusban a kinetikák tipikus OJIP tranzienseket mutatnak. A $20 \mu$ s-nál mért fluoreszcencia szintet tekintettük $\mathrm{F}_{\mathrm{o}}$-nak, a $\mathrm{J}$ szintet $\mathrm{kb}$. 1,5-2 ms-nál, az I szintet kb. 30 ms-nál és a maximális, P szintet $\left(\mathrm{F}_{\mathrm{m}}\right)$ kb. 200 ms-nál éri el a tranziens az AS vonalakban, és később, kb. 280 ms-nál az AR biotípusokban. Szemmel láthatóan az S264G D1 mutáció hatással van a 
tranziensek alakjára, és a szülö biotípus és a megfelelö hibridjei nem különböztek egymástól. Az AR típusokban az $F_{0}$ és $F_{J}$ szintek szignifikánsan magasabb értékeket mutattak $(p=0,05)$, az $\mathrm{F}_{\mathrm{m}}$ szintek pedig alacsonyabbakat (az ARF2 kivételével), mint az AS párjaikban. Az $\mathrm{F}_{\mathrm{I}}$ tranziens kevésbé kifejezetten jelent meg az AR, mint az AS típusban, azonban szignifikáns különbség csupán az F2 hibridek esetében adódott.
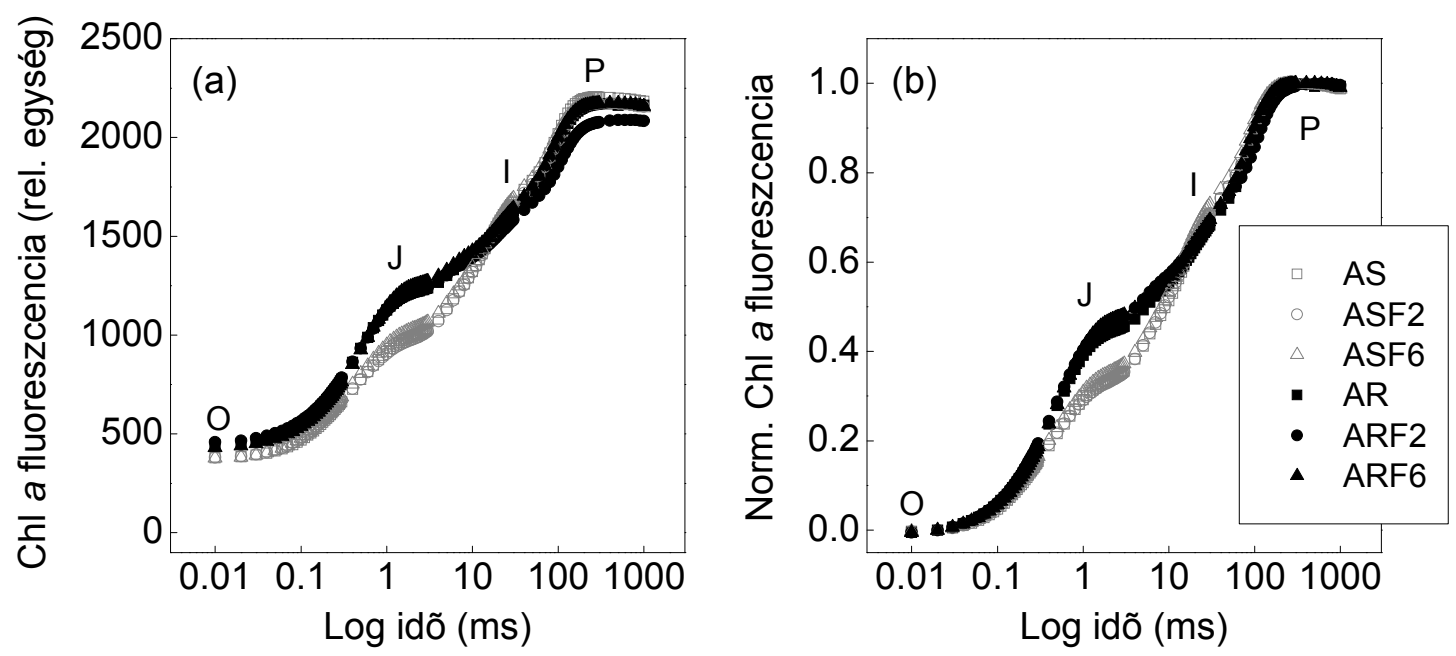

6. ábra Gyors Chl fluoreszcencia tranziensek (OJIP) AS (üres szimbólum) és AR (teli szimbólum) S. nigrum biotípusok leveleiben és hibridjeikben, melyeket 1 s idötartamig, 3000 umol foton $\mathrm{m}^{-2} \mathrm{~s}^{-1}$ fotonáram-sürüséggel világítottunk meg. AS és AR, szülö, $\square$ és

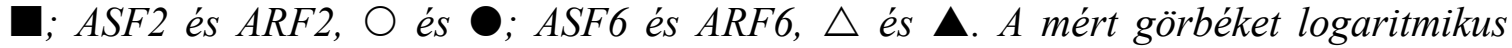
időskálán ábrázoltuk (a). A (b) panel a változó fluoreszcenciára $\left(F_{v}\right)$ normalizált görbéket mutatja, $\left(F_{t}-F_{o}\right) /\left(F_{m}-F_{o}\right)$. Az adatok három független kísérlet egyikét reprezentálják, ahol $n=16$.

A 5. táblázatban bemutatom a $S$. nigrum vonalakra jellemző JIP-teszt paramétereket. Az AR növényekben a PSII primér fotokémiájának maximális hatásfoka $\left(\varphi_{\text {Po }}=F_{\mathrm{v}} / F_{\mathrm{m}}\right)$ szignifikánsan alacsonyabbnak bizonyult AS párjaikkal szemben. A RC-ok záródásának nettó sebessége, azaz a normalizált fluoreszcencia görbe kezdeti meredeksége $\left(\mathrm{M}_{\mathrm{O}}\right)$, szignifikánsan megnőtt a $\mathrm{Q}_{\mathrm{A}}$ redukált formájának fokozott felhalmozódása miatt $\left(\mathrm{V}_{\mathrm{J}}\right)$ az AR típusokban. 
5. táblázat JIP-teszt paraméterek a különbözö S. nigrum vonalakban

\begin{tabular}{|c|c|c|c|c|c|c|}
\hline \multirow[b]{2}{*}{$\begin{array}{l}\text { JIP-teszt } \\
\text { paraméter }\end{array}$} & \multicolumn{6}{|c|}{ Biotípus } \\
\hline & AS & $A R$ & ASF2 & ARF2 & ASF6 & ARF6 \\
\hline$\varphi_{\text {Po }}\left(F_{\mathrm{v}} / F_{m}\right)$ & $0,821 \pm 0,007$ & $0,801 \pm 0,011^{a}$ & $0,826 \pm 0,003$ & $0,793 \pm 0,023^{a}$ & $0,829 \pm 0,003$ & $0,796 \pm 0,026^{a}$ \\
\hline$\varphi_{\text {Do }}$ & $0,179 \pm 0,007$ & $0,199 \pm 0,011^{a}$ & $0,174 \pm 0,003$ & $0,207 \pm 0,023^{\mathrm{a}}$ & $0,171 \pm 0,003$ & $0,204 \pm 0,026^{a}$ \\
\hline$M_{0}$ & $0,787 \pm 0,108$ & $0,906 \pm 0,062^{\mathrm{a}}$ & $0,769 \pm 0,048$ & $0,913 \pm 0,086^{a}$ & $0,728 \pm 0,045$ & $0,986 \pm 0,091^{a}$ \\
\hline $\mathrm{V}_{\mathrm{J}}$ & $0,382 \pm 0,036$ & $0,497 \pm 0,014^{a}$ & $0,382 \pm 0,013$ & $0,517 \pm 0,024^{a}$ & $0,374 \pm 0,016$ & $0,528 \pm 0,013^{a}$ \\
\hline$V_{1}$ & $0,784 \pm 0,034$ & $0,776 \pm 0,020$ & $0,768 \pm 0,028$ & $0,727 \pm 0,019^{b}$ & $0,762 \pm 0,026$ & $0,761 \pm 0,025$ \\
\hline$\Psi_{\text {EO }}$ & $0,618 \pm 0,036$ & $0,505 \pm 0,021^{a}$ & $0,618 \pm 0,013$ & $0,486 \pm 0,023^{a}$ & $0,626 \pm 0,016$ & $0,471 \pm 0,013^{a}$ \\
\hline$\varphi_{\mathrm{Eo}}$ & $0,507 \pm 0,025$ & $0,405 \pm 0,019^{a}$ & $0,511 \pm 0,011$ & $0,385 \pm 0,025^{a}$ & $0,519 \pm 0,015$ & $0,373 \pm 0,019^{a}$ \\
\hline$\Psi_{\mathrm{Ro}}$ & $0,216 \pm 0,034$ & $0,224 \pm 0,021$ & $0,232 \pm 0,015$ & $0,258 \pm 0,019^{b}$ & $0,237 \pm 0,029$ & $0,244 \pm 0,029$ \\
\hline$\varphi_{\text {Ro }}$ & $0,177 \pm 0,027$ & $0,179 \pm 0,016$ & $0,192 \pm 0,023$ & $0,218 \pm 0,018$ & $0,197 \pm 0,022$ & $0,193 \pm 0,026$ \\
\hline$\delta_{\mathrm{Ro}}$ & $0,348 \pm 0,041$ & $0,447 \pm 0,038^{\mathrm{a}}$ & $0,376 \pm 0,042$ & $0,573 \pm 0,065^{a}$ & $0,379 \pm 0,032$ & $0,518 \pm 0,064^{a}$ \\
\hline $\mathrm{ET}_{\mathrm{o}} / \mathrm{RC}$ & $1,285 \pm 0,064$ & $0,872 \pm 0,044^{a}$ & $1,242 \pm 0,050$ & $0,862 \pm 0,060^{a}$ & $1,218 \pm 0,036$ & $0,876 \pm 0,059^{a}$ \\
\hline $\mathrm{RE}_{\mathrm{o}} / \mathrm{RC}$ & $0,426 \pm 0,044$ & $0,422 \pm 0,049$ & $0,483 \pm 0,064$ & $0,496 \pm 0,086$ & $0,462 \pm 0,045$ & $0,441 \pm 0,055$ \\
\hline $\mathrm{Pl}_{\mathrm{abs}}$ & $29,60 \pm 5,62$ & $18,77 \pm 3,59^{a}$ & $31,79 \pm 3,27$ & $16,85 \pm 4,93^{\mathrm{a}}$ & $34,98 \pm 3,57$ & $15,42 \pm 3,41^{a}$ \\
\hline $\mathrm{PI}_{\text {total }}$ & $16,29 \pm 4,94$ & $15,12 \pm 3,56$ & $19,31 \pm 3,91$ & $22,15 \pm 3,29^{c}$ & $19,22 \pm 4,14$ & $16,80 \pm 4,08^{\mathrm{C}}$ \\
\hline
\end{tabular}

Az adatok három független kísérlet egyikét reprezentálják, ahol $n=16$.

$A z$ “a, b, és c” szignifikáns eltérést jelölik a két biotípus között 0,1, 1 és 5\%-os tévedési valószínüségi szinten.

Magyarázat: $\varphi_{P o}\left(F_{v} / F_{m}\right)$, PSII primér fotokémiájának maximális hatásfoka; $\varphi_{D o}$, energia disszipáció hatásfoka; $M_{o}$, fluoreszcencia tranziens $V=f(t)$ approximatív kezdeti meredeksége $\left(m s^{-1}\right)$, a RC-k záródásának nettó sebessége; $V_{J}$, relatív változó fluoreszcencia a J inflexiónál, mely tükrözi mind a $Q_{A}{ }^{-}$felhalmozódásának, mind re-oxidációjának sebességét; $V_{I}$, relatív változó fluoreszcencia az I inflexiónál, mely a plasztokinol re-oxidációjának sebességét tükrözi; $\psi_{E o}$, annak a valószínüsége, hogy egy RC által befogott exciton egy elektront az elektrontranszportláncba juttat a $Q_{A}{ }^{-}-n$ túl; $\varphi_{E o}$, elektrontranszport hatásfoka a köztes elektron hordozók irányában (azaz egy elnyelt foton milyen hatásfokkal eredményez elektrontranszportot a $Q_{A}{ }^{-}-n$ túl); $\psi_{R o}$, annak a valószinüsége, hogy egy $R C$ által befogott exciton egy elektront az elektrontranszportláncba juttat a $Q_{A}^{-}$felöl a PSI végsö elektron akceptorokhoz; $\varphi_{R o}$, a PSI végső elektron akceptorok redukciójának hatásfoka az elnyelt fotonok arányában; $\delta_{R o}$, annak a valószínüsége, hogy egy elektron a köztes elektron akceptorok felöl a PSI végsö elektron akceptorokhoz jut; ET $/ R C$, elektrontranszport fluxusa (a $Q_{A}{ }^{-}$-on túlra definiált) per $R C ; R E_{o} / R C$, PSI végsö elektron akceptor redukciójának fluxusa

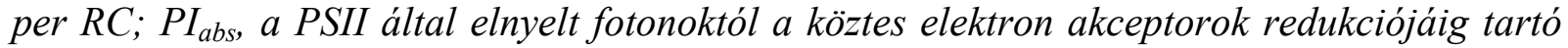
energia konverziót jellemzö fotoszintetikus teljesitmény index; PI $I_{\text {total a }}$ a PSI által elnyelt fotonoktól a PSI végsö elektron akceptorokig tartó energia konverziót jellemzö teljes fotoszintetikus teljesítmény index. 
További informatív paraméterek értékei, úgymint (i) annak a valószínüsége, hogy egy RC által befogott exciton egy elektront az elektrontranszportláncba juttat a $\mathrm{Q}_{\mathrm{A}}{ }^{-} \mathrm{n}$ túl $\left(\psi_{\mathrm{Eo}}\right),(\mathrm{ii})$ az elektrontranszport fluxusa per $\mathrm{RC}\left(\mathrm{ET}_{\mathrm{o}} / \mathrm{RC}\right)$ és (iii) a fotoszintetikus teljesítmény index $\left(\mathrm{PI}_{\mathrm{abs}}\right)$ valamennyien szignifikánsan csökkentek, míg az energia disszipáció hatásfoka ( $\left.\varphi_{D o}\right)$ megemelkedett az AR típusokban, az AS vonalakhoz képest (5. táblázat). A mutációt hordozó vonalak $\mathrm{PI}_{\mathrm{abs}}$ értékei 50\%-os csökkenést mutattak, ami a szignifikánsan alacsonyabb gerjesztési energia befogási aránynak $\varphi_{\mathrm{Po}} /\left(1-\varphi_{\mathrm{Po}}\right)$, valamint a gerjesztési energia elektrontranszportba történő kisebb arányú konverziójának $\psi_{\mathrm{Eo}} /\left(1-\psi_{\mathrm{Eo}}\right)$ köszönhető (7. ábra).

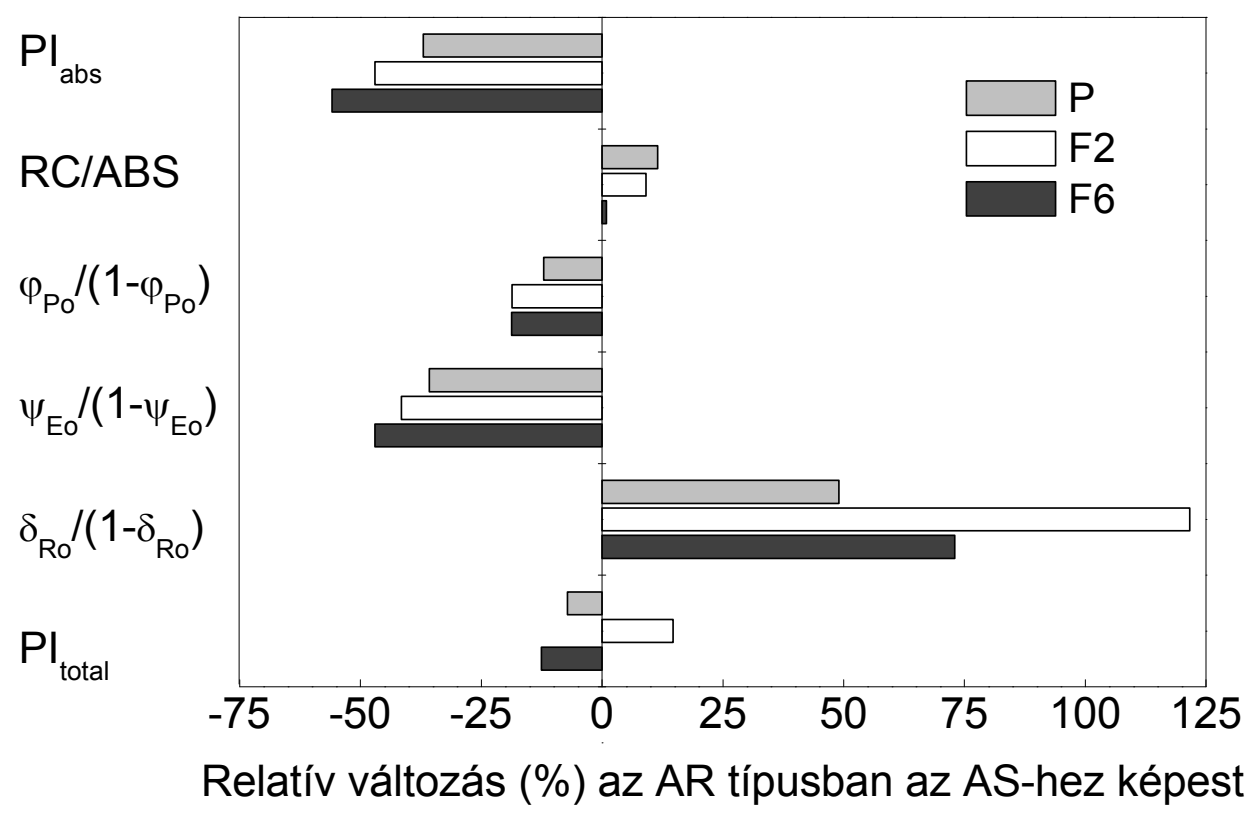

7. ábra A D1 protein mutáció hatása a fotoszintetikus teljesitmény indexekre (PI $I_{a b s}$ és $\left.P I_{\text {total }}\right)$, és komponenseikre, nevezetesen: (1) a $Q_{A}$-redukáló $R C$-ok per PSII antenna Chl (RC/ABS); (2) a gerjesztési energia befogás és disszipáció aránya $\left(Q_{A}{ }^{-}-i g\right.$ definiálva) ( $\varphi_{P o} /\left(1-\varphi_{P o}\right)$; (3) az elektrontranszportba történö gerjesztési energia konverzió (és konkurrens disszipáció) aránya $\left(Q_{A}{ }^{-} n\right.$ túlra definiálva) $\left(\psi_{E o} /\left(1-\psi_{E o}\right)\right)$; (4) a redukált köztes elektron akceptorok felöl a PSI végső akceptorokhoz eljutó és el nem jutó elektronok aránya $\left(\delta_{R o} /\left(1-\delta_{R o}\right)\right)$. AS és AR szülö populáció, a $S$. nigrum vad és D1 mutáns biotípusai; P, szürke oszlop, szülö populáció; és ezek F2 és F6 hibridjei, rendre F2 és F6, fehér és fekete oszlopok. A vízszintes oszlopok a különbözö paraméterek relatív változásait jelölik \%-ban az AR típusban az AS-hez viszonyítva. Az adatok három független kísérlet egyikét reprezentálják, ahol $n=16$. 
Az OJIP tranziensekből JIP-teszt analízissel nyomonkövethető az elektronok vándorlása a redukált köztes elektron akceptoroktól ( $\mathrm{Q}_{\mathrm{B}}, \mathrm{PQ}, \mathrm{Cyt} b_{6} / f$ és plasztocianin) a PSI akceptor oldali komponenseinek $\left(\mathrm{NADP}^{+}\right.$és $\left.\mathrm{Fd}\right)$ redukciójáig, valamint meghatározható a teljes, a PSI végső akceptorokig tartó, fotoszintetikus teljesítmény index ( $\left.\mathrm{PI}_{\text {total }}\right)$ (5. táblázat). Annak a valószínűsége, hogy egy elektron a köztes elektron akceptorok felől a PSI végső elektron akceptorokhoz jut $\left(\delta_{\text {Ro }}\right)$, szignifikánsan megemelkedett az AR vonalakban AS párjaikhoz képest, miközben nem találtunk szignifikáns eltéréseket a kétféle biotípusban a PSI végső elektron akceptorok redukciójának fluxusa per $\mathrm{RC}$ tekintetében $\left(\mathrm{RE}_{\mathrm{o}} / \mathrm{RC}\right)$, a PSI végső elektron akceptorok redukciójának hatásfokában az elnyelt fotonok arányában $\left(\varphi_{\mathrm{Ro}}\right)$, valamint annak a valószínüségében sem, hogy egy RC által befogott exciton egy elektront az elektrontranszportláncba juttat a $\mathrm{Q}_{\mathrm{A}}{ }^{-}$felöl a PSI végső elektron akceptorokhoz $\left(\psi_{\mathrm{Ro}}\right)$. $\mathrm{A} \mathrm{PI}_{\text {total }} \mathrm{a}$

fotoszintetikus teljesítmény index $\left(\mathrm{PI}_{\mathrm{abs}}\right)$ és a $\delta_{\mathrm{Ro}} /\left(1-\delta_{\mathrm{Ro}}\right)$ arányszám szorzata, amely a redukált köztes elektron akceptorok felöl a PSI végső akceptorokhoz jutó elektronok aránya. A $\delta_{\mathrm{Ro}} /\left(1-\delta_{\mathrm{Ro}}\right)$ arányszám emelkedésének köszönhető teljesítmény-növekedés valószínűleg kompenzálhatja a PSII akceptor oldali alacsonyabb elektronáram-sebességet az AR típusban, nem szignifikáns mértékben eltérő $\mathrm{PI}_{\text {total }}$ értékeket eredményezve ezzel a kétféle biotípusban (5. táblázat).

\subsubsection{Az NPQ és az elnyelt fényenergia allokációja a PSII-ben}

A 8. ábra bemutatja az NPQ fényintenzitástól való függését $(a)$, és $1250 \mu \mathrm{mol}$ foton $\mathrm{m}^{-2} \mathrm{~s}^{-1}$ aktinikus fénnyel történő indukcióját valamint sötétrelaxációját (b). Jellemzően a fényintenzitás emelkedésével az NPQ növekedett valamennyi biotípusban és vonalban. Az AR szülő biotípus és hibridjei szignifikánsan alacsonyabb NPQ kapacitással bírtak, mint az AS párjaik (8. a ábra). A $\Phi_{\mathrm{PSII}}, \mathrm{J}_{\mathrm{ETR}}$, NPQ és $1-\mathrm{qP}$ paraméterek fényintenzitás függése a PSII müködésének lecsökkent regulációs képességéről árulkodik valamennyi AR típusban (AR, ARF2, ARF6) az AS párjaikkal szemben (AS, ASF2, ASF6) (5. a, b, c és 8. a ábrák). A sötétadaptált levél megvilágítása után az NPQ kialakulása során két fázis különíthető el, egy gyors és egy lassú. Az AS típusokban egy gyors kezdeti emelkedés figyelhető meg, mely kb. $60 \mathrm{~s}$ alatt éri el az 1,1 értéket, és jórészt független a xantofill ciklus működésétől (8. b ábra), melyet egy xantofill ciklus függö, lassabb emelkedés követ, 15 perc alatt elérve a közel 
steady-state 1,7 értéket. Ezt követően az aktinikus fény kikapcsolása után az NPQ relaxálódott, melynek féléletideje az AS típusokban kb. 2,8 \pm 0,2 perc volt.
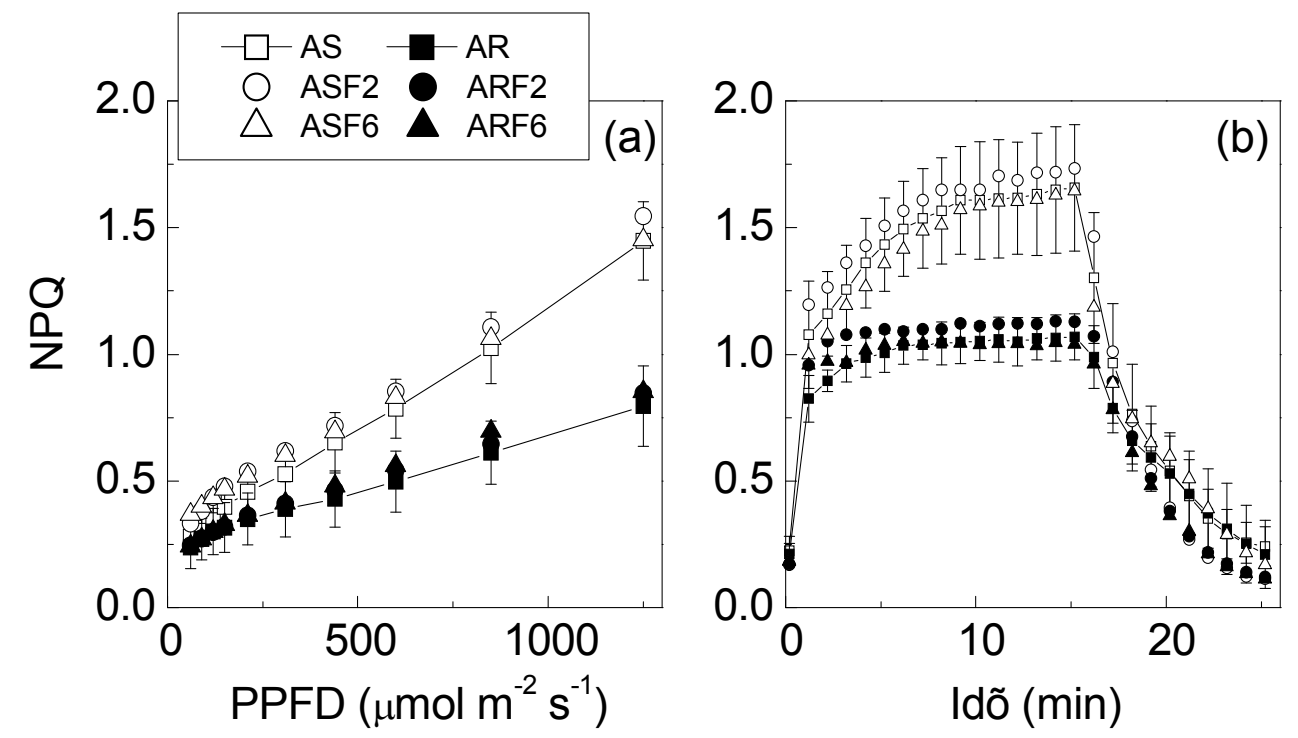

8. ábra Az NPQ aktinikus fényre adott válaszgörbéi (a) és az NPQ indukciója (1250 umol foton $\mathrm{m}^{-2} \mathrm{~s}^{-1}, 15$ perc) és sötétrelaxációja (b) AS (üres szimbólum) és AR (teli szimbólum) $S$. nigrum biotípusok leveleiben. AS és AR, szülö, - $\square-$ és - - -; ASF2 és ARF2, $\bigcirc$ és O; ASF6 és ARF6, $\triangle$ és $\boldsymbol{\Delta}$. Az adatok három független kísérletböl 12 ismétlés átlagai. A SD a szülö (AS és AR) populációkban van feltüntetve.

Az AR biotípusban viszont az NPQ legnagyobb része a megvilágítás első percében kialakult, de a gyors kezdeti fázis kb. 25\%-kal volt alacsonyabb, mint az AS típusokban. Majd némileg lassan emelkedett és elérte az 1,1-hez közeli steady-sate értéket. Az NPQ relaxáció féléletideje kb. 5,0 $\pm 0,3$ perc volt az AR típusok esetében.

A D1 fehérje mutáció hátterének és lehetséges következményeinek megértése érdekében megvizsgáltuk a PSII antenna által elnyelt fényenergia sorsát. Az elnyelt energia egyrészt fotokémiailag hasznosulhat, másrészt a disszipatív folyamatok eliminálhatják a PSII antennarendszeréből. A 9. ábra az elnyelt fényenergia PSII-ben történő megoszlásának fényintenzitás függését mutatja be Demmig-Adams és munkatársai (1996) modellje alapján. Mindkét biotípusban a fotokémia által hasznosuló energia frakció ( $\left.\Phi_{\mathrm{PSII}}\right)$ csökkenő tendenciát mutatott a beeső fényintenzitás növelésekor, míg a fényben disszipált energia $\left(\Phi_{\mathrm{DL}}\right)$ illetve az 
ún. többletenergia disszipáció $\left(\Phi_{\mathrm{E}}\right)$ egyaránt növekedett a fényintenzitás emelkedésével. Az AS és AR szülö biotípusok között és a megfelelö hibridjeik között jellegzetes különbségek mutatkoztak (9. a és b ábrák). A $\Phi_{\mathrm{PSII}}$ szignifikánsan, kb. 30\%-kal volt kisebb valamennyi AR vonalban, azonban a $\Phi_{\mathrm{DL}} \mathrm{kb} .35 \%-\mathrm{kal}$, a $\Phi_{\mathrm{E}}$ pedig $\mathrm{kb} .80 \%$-kal megemelkedett az AR típusokban AS párjaikhoz képest.
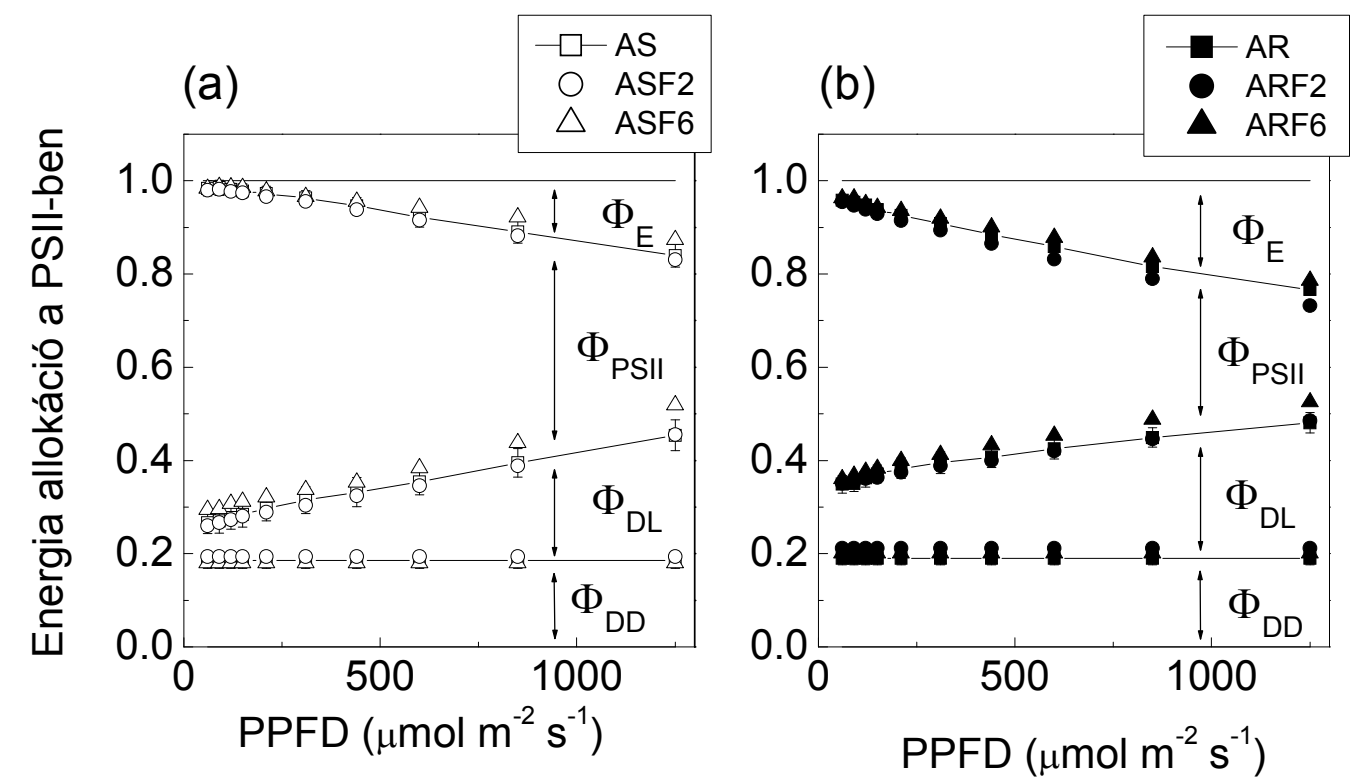

9. ábra Az elnyelt fényenergia megoszlása a PSII-ben Demmig-Adams és munkatársai (1996) modellje szerint az AS (üres szimbólum) (a) és az AR (teli szimbólum) (b) S. nigrum biotípusok leveleiben és ezek hibridjeiben. AS és AR, szülö, - $\square-$ és - -; ASF2 és ARF2, $\bigcirc$ és $\mathbf{0}$; ASF6 és ARF6, $\triangle$ és $\boldsymbol{\Delta}$. $\Phi_{E}, \Phi_{P S I}$, $\Phi_{D L}$ és $\Phi_{D D}$ : rendre, a többletenergia, a PSII fotokémiára hasznosuló energia, a fényben történö hödisszipáció és a sötétben történö energiaveszteség frakciói. A nyíllal jelölt, görbék közti területek a megfelelö hatásfokokkal arányosak. Az adatok három független kisérletböl 6-7 ismétlés átlagai. A SD a szülö (AS és AR) populációkban van feltüntetve.

Egy ennél egyszerübb modell alkalmazásával (Hendrickson et al., 2004) mennyiségileg meghatároztuk a gerjesztési energia allokációját (10. ábra), amely három egymást kiegészítő PSII hatásfokon alapszik. A gerjesztési energia hasznosulhat a fotokémia 
által $\left(\Phi_{\mathrm{PSI}}\right)$, illetve eliminálódhat a regulált hődisszipáció $\left(\Phi_{\mathrm{NPQ}}\right)$ és a nem-regulált (konstitutív) energia disszipáció $\left(\Phi_{\mathrm{NO}}\right)$ során a PSII-ben. A 10 . ábrán láthatók a $\Phi_{\mathrm{PSII}}, \Phi_{\mathrm{NPQ}}$ és $\Phi_{\mathrm{NO}}$ fényintenzitás függéseinek összehasonlítása a $S$. nigrum vonalakban (10. a, c és e ábrák); valamint a fotokémiában hasznosuló elektronok transzportjának sebessége $\left(\mathrm{J}_{\mathrm{ETR}}\right)$, a regulált $\left(\mathrm{J}_{\mathrm{NPQ}}\right)$ és a nem-regulált disszipációs folyamatok sebességei $\left(\mathrm{J}_{\mathrm{NO}}\right)$ (10. b, d és f ábrák), amelyek a leveleken meghatározott $\mathrm{F}_{\mathrm{m}}, \mathrm{F}_{\mathrm{m}}$ és $\mathrm{F}$ fluoreszcencia paraméterekből számolhatók. A $\Phi_{\text {PSII }}$ értékei közel azonos sebességgel csökkentek a kétféle biotípusban a fényintenzitás növekedésével, azonban az AR következetesen alacsonyabb értékeket vett fel (10. a ábra) (ahogy ezt már az 5. a és 9. ábrákon is szemléltettem), mialatt a $\mathrm{J}_{\mathrm{ETR}}$ növekedési üteme az AR típusokban hangsúlyosabban lecsökkent (10. b és 5 . b ábrák). A $\Phi_{\mathrm{NPQ}}$ és $\mathrm{J}_{\mathrm{NPQ}}$ (10. c és d ábrák) aktinikus fényre adott válaszgörbéi az AS és AR szülö biotípusokban, valamint a hibridjeikben is megegyeztek. Alacsony fényintenzitásokon a $J_{\mathrm{NPQ}}$ igen alacsony volt, majd exponenciálisan emelkedett a fényintenzitással mindkét biotípusban (10. d ábra). A $\Phi_{\mathrm{NO}}$ értékeiben szignifikáns emelkedést (kb. 60-80\%) tapasztaltunk az AR vonalakban az AS párjaikkal összevetve $(\mathrm{p}=0,001)$ (10. e ábra), ami enyhén emelkedett a fényintenzitással. Az AS növényekben a $\Phi_{\mathrm{NO}}$ értékek a sötétadaptált mintákra jellemző $\mathrm{F}_{\mathrm{o}} / \mathrm{F}_{\mathrm{m}}$ értékeket közelítették, és a fényintenzitás emelkedése gyakorlatilag nem befolyásolta a hatásfokot. A konstitutív energia disszipáció sebességei $\left(\mathrm{J}_{\mathrm{NO}}\right)$ mindkét típusban lineárisan emelkedtek, az emelkedés az AR típusokban szignifikánsan meredekebb volt (10. f ábra).

Az NPQ kialakulásában a PsbS fehérjének kulcsfontosságú szerepet tulajdonítanak. Felmerült, hogy egy esetleges pontmutáció a $p s b S$ génben részben magyarázhatná az $\mathrm{AR}$ biotípus alacsonyabb fény-indukált NPQ kapacitását, ezért meghatároztuk a $S$. nigrum AS és AR biotípusainak psbS génszekvenciáját annak érdekében, hogy felfedjük a PsbS fehérje esetleges aminosav változásait. A $p s b S$ génre specifikus primer párokat (primerek Pr-SniF1, Pr-SniR1, Pr-SniF2, Pr-SniR2 és Pr-SniStop-F1, Pr-SniStop-R1, lásd: Anyag és Módszer fejezet 2. táblázata) terveztünk és szintetizáltattunk a $S$. nigrum egy közeli rokona, a $S$. sogarandinum PsbS cDNS szekvenciájának (Gén Bank nyilvántartási szám: AF311720) ismert nukleotid sorrendje alapján. Az AS és AR biotípusokban a teljes hosszúságú $p s b S$ gén szekvenciájában négy nukleotidot érintő különbséget kaptunk. Ezek közül kettő intronokban lokalizált, a másik két változás, a két érintett kodon harmadik pozíciójában található, amelyek 
nem változtatják meg az aminosav kódot: GGT $\rightarrow$ GGC mindkettő glicint kódol és $\mathrm{ACC} \rightarrow \mathrm{ACT}$ mindkettő treonint kódol.
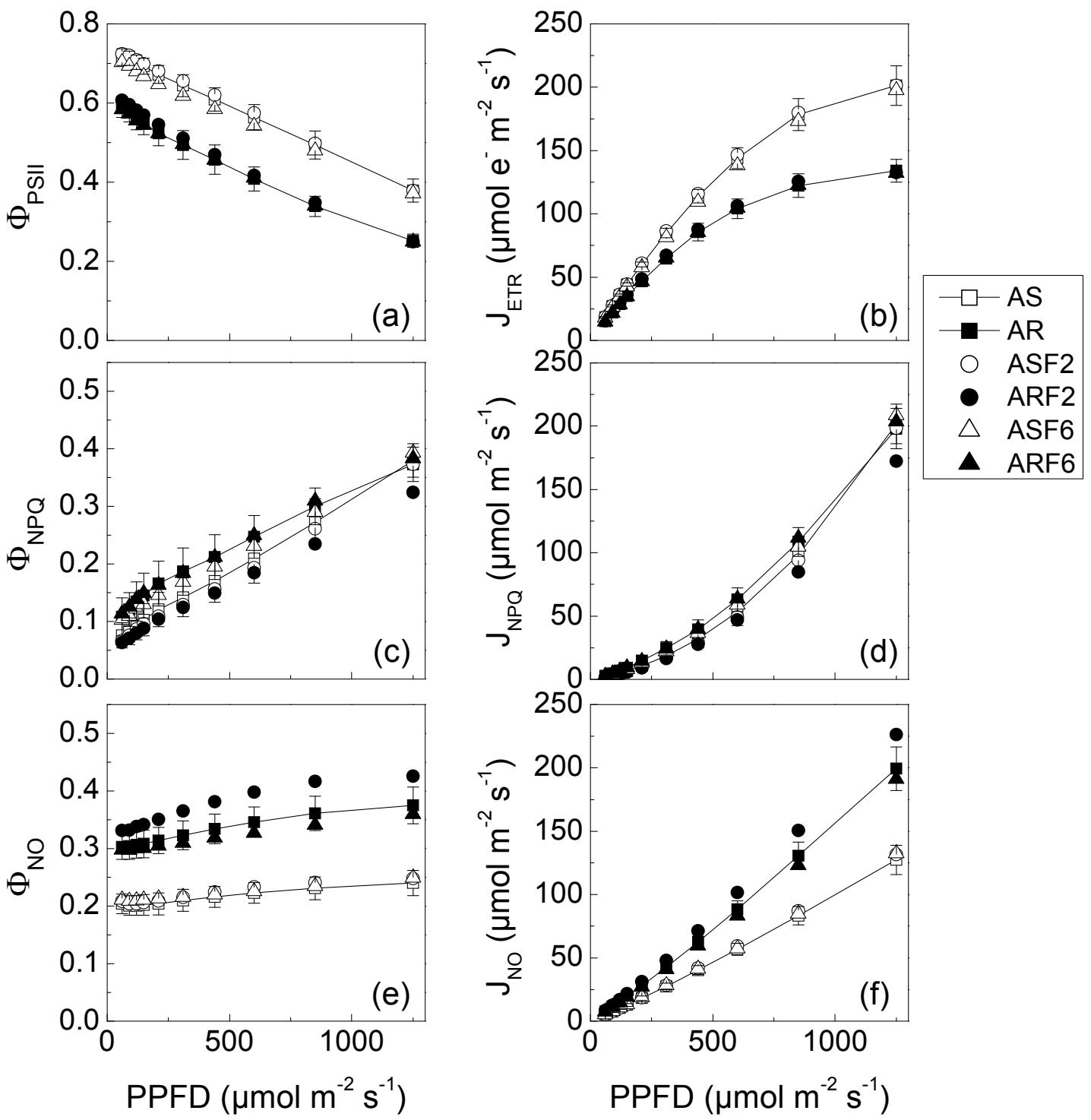

10. ábra A PSII komplementer hatásfokainak (Hendrickson et al., 2004) és e folyamatok sebességeinek fényintenzitás függése $A S$ (üres szimbólum) és AR (teli szimbólum) $S$. nigrum biotipusok leveleiben, és hibridjeikben. AS és AR, szülö, - $\square-$ és-口-; ASF2 és ARF2, $\bigcirc$ és $\mathbf{0}$; ASF6 és ARF6, $\triangle$ és $\boldsymbol{\Delta}$. Grafikonok: $(a, b)$ a fotokémiai energia konverzió hatásfoka $\Phi_{P S I I} ;(c$, d) a regulált energia disszipáció hatásfoka $\Phi_{N P Q}$; $(e, f)$ a nem-regulált energia disszipáció hatásfoka $\Phi_{N O} . J_{E T R}, J_{N P Q}, J_{N O}$, rendre a lineráis elektrontranszport, a regulált hödisszipáció és a nem-regulált energia disszipáció sebességeit jelölik. Az adatok három független kísérletböl 12 ismétlés átlagai. A SD a szülö (AS és AR) populációkban van feltüntetve. 
Tehát a szekvencia analízis alapján a $S$. nigrum növény AS (Gén Bank nyilvántartási szám: DQ632747) és AR (Gén Bank nyilvántartási szám: DQ632748) biotípusaiban azonosak a PsbS fehérjék, azaz nem tartalmaznak aminosav eltérést (11. ábra). A $S$. nigrum biotípusok DNS szekvenciájából levezetett aminosav szekvencia nagyfokú homológiát mutat a Genebank-ban (http://www.ncbi.nlm.nih.gov/) megtalálható egyéb PsbS fehérje szekvenciákkal.

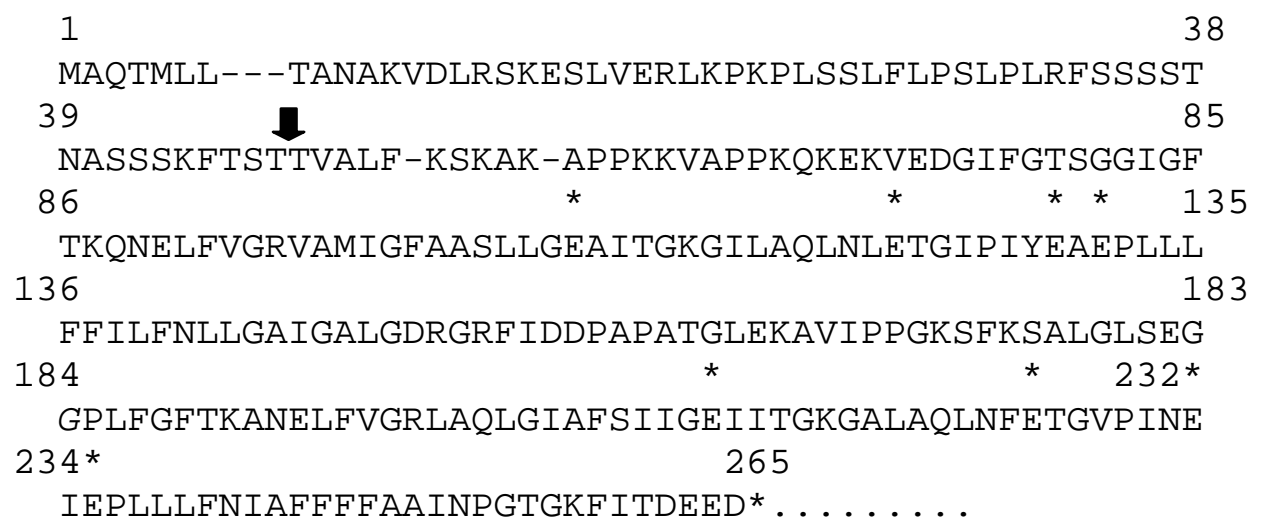

11. ábra $A$ S. nigrum PsbS fehérjéjének várható aminosav szekvenciája. A számozás az A. thaliana szekvenciáján alapul. A hasitási helyet, ahol a fehérjét elvágtuk a

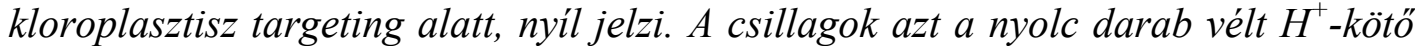
aminosavat jelölik, melyek várhatóan a tilakoid lumennel szemben helyezkednek el.

A PsbS fehérje expressziós szintje fontos tényező lehet a növény teljes NPQ kapacitásának meghatározásakor. Immunoblot módszerrel specifikus antitestek alkalmazásával megvizsgáltuk a PsbS és a D1 fehérjék expresszióját, hogy felfedjük, vajon a PsbS fehérje szerepet játszik-e az AS és AR vonalak eltérő NPQ kapacitásában (12. ábra). A PsbS és PsbA western blotjainak denzitometriai analízisén végzett student t-teszt nem mutatott szignifikáns eltérést a fehérje mennyiségében az AS és az AR vonalak között $(p=0,05)$. Azonfelül e két kulcsfehérje aránya gyakorlatilag változatlan maradt a biotípusokban. 


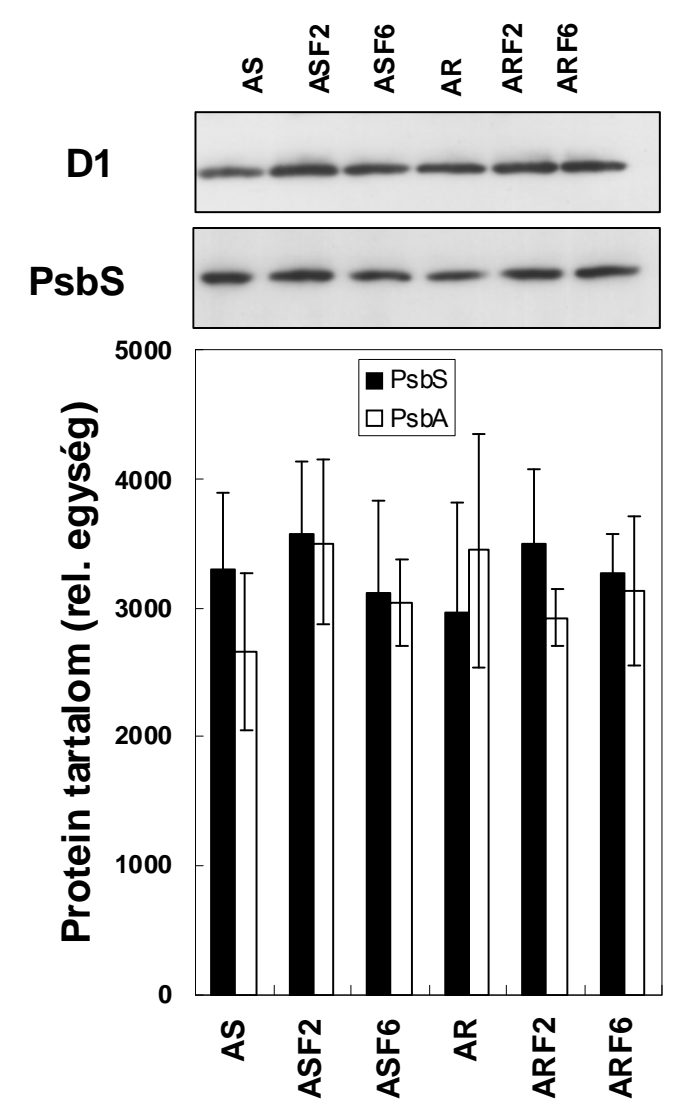

12. ábra $S$. nigrum növény $A S$ és AR szülö, valamint ezek reciprok keresztezéseiböl származó $F 2$ és F6 utódnövények PsbA (D1) és PsbS fehérjéinek tipikus immunoblot analizise és ezek relativ tartalma. A relativ fehérje tartalom adatai átlag $\pm S D(n=5-6)$.

\subsubsection{A S. nigrum vonalak sejtmagi hibrid státuszának igazolása}

Mivel a $p s b A$ gén citoplazmatikus, a $p s b S$ gén pedig sejtmagi öröklödésü, fontos azt megerősítenünk, hogy az AS és az AR szülő biotípusok reciprok keresztezése sikeres volt-e. Független belső indikátorként egy mendeli tulajdonságot, a levélszél alakjának öröklődését követtük nyomon, mely bizonyítja az F2 növényi anyag sejtmagi hibrid státuszának meglétét. A levélszél tekintetében síma, csipkézett vagy köztes típust találtunk (13. ábra), amelyek különböző gyakorisággal fordultak elő a szülő populációkban (6. táblázat). Miként az F2 nemzedék levélszél típusának várható - a Hardy-Weinberg modell szerint kalkulált szegregációja és a kísérletesen megfigyelt adatok nem különböztek szignifikánsan (7. táblázat; $P<0,05 ; \chi^{2}$ teszt), biztonsággal megállapíthattuk, hogy a levélszél alakja a mendeli szabályok szerint öröklődött, mely az F2 populáció hibrid státuszának meglétét bizonyítja. 


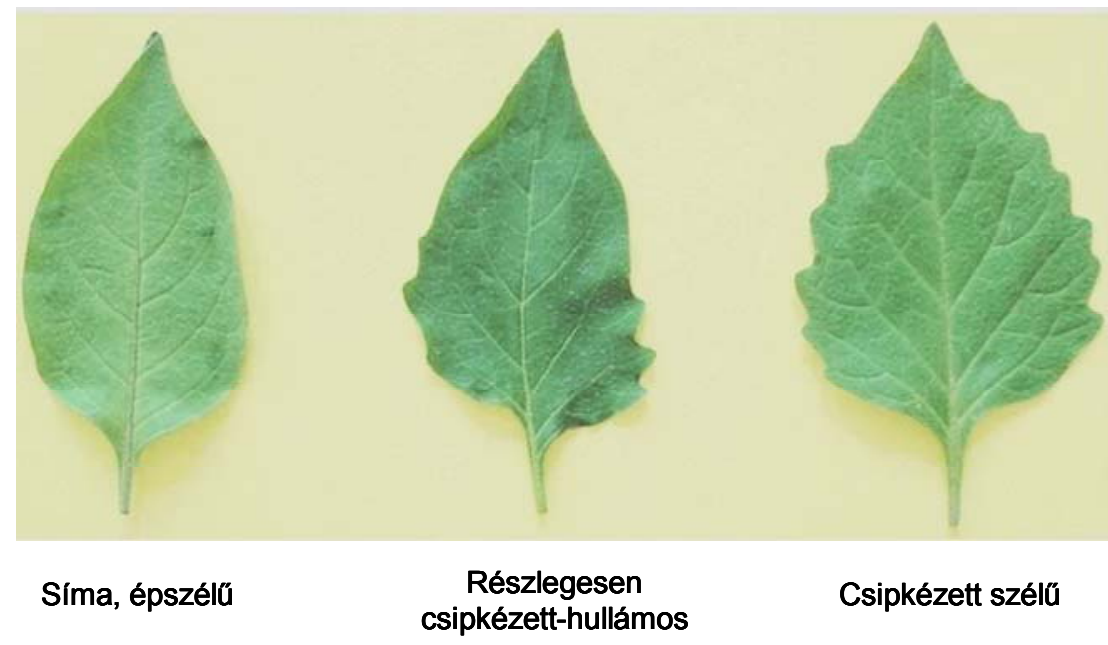

13. ábra A S. nigrum levélszéle síma, csipkézett vagy köztes típusú volt.

6. táblázat A S. nigrum szülö populáció levélszél típusai és az $N P Q$ (vagy qE) karakterisztika

\begin{tabular}{lcccc}
\hline \multirow{2}{*}{ Szülő populáció } & \multicolumn{3}{c}{ Levélszél típus gyakoriság } & \multirow{2}{*}{$\mathrm{NPQ}$} \\
\cline { 2 - 4 } & síma & köztes & csipkézett & \\
\hline Atrazin-szenzitív & 0,67 & 0,11 & 0,22 & Magas \\
Atrazin-rezisztens & 0,01 & 0,11 & 0,88 & Alacsony \\
\hline
\end{tabular}

$n=208$ mindkét szülöpopuláció estetében

7. táblázat $S$. nigrum F2 populáció tulajdonságai és az NPQ (vagy qE) tulajdonság

\begin{tabular}{|c|c|c|c|c|c|c|}
\hline \multirow[t]{2}{*}{ Genetikai keresztezés } & \multirow[t]{2}{*}{ Eredmény } & \multicolumn{3}{|c|}{$\begin{array}{c}\text { Különböző levélszéltípusú } \\
\text { növények darabszáma }\end{array}$} & \multirow{2}{*}{$\begin{array}{c}\text { Atrazinra } \\
\text { adott } \\
\text { válasz }\end{array}$} & \multirow{2}{*}{$\begin{array}{c}\mathrm{NPQ} \\
\text { (vagy } \mathrm{qE})\end{array}$} \\
\hline & & síma & köztes & csipkézett & & \\
\hline \multirow{2}{*}{ 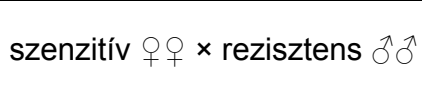 } & Megfigyelt & 13 & 31 & 41 & \multirow{2}{*}{$\begin{array}{l}\text { Mind } \\
\text { szenzitiv }\end{array}$} & \multirow{2}{*}{ Magas } \\
\hline & Várható* & 14 & 22 & 49 & & \\
\hline \multirow{2}{*}{ 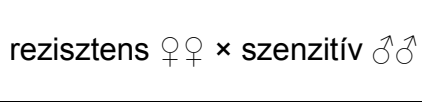 } & Megfigyelt & 22 & 52 & 68 & \multirow{2}{*}{$\begin{array}{l}\text { Mind } \\
\text { rezisztens }\end{array}$} & \multirow{2}{*}{ Alacsony } \\
\hline & Várható* & 14 & 53 & 75 & & \\
\hline
\end{tabular}

*A szülökben és az F1 populációban elöforduló allélgyakoriságok alapján határoztuk meg 
Valamennyi F1 és F2 utódnövény (F6 nemzedékig), mely AS $q \times$ AR ổ keresztezésből való volt, AS, és valamennyi utódnövény, amely AR $q \times$ AS ổ keresztezésból származott, AR biotípusú volt, amely bizonyította a kloroplasztisz-DNS által kódolt atrazin rezisztencia anyai öröklődését. Az alacsonyabb NPQ (vagy qE) tulajdonság az anyai öröklődésủ AR jelleget követte. Annak bizonyítására, hogy a D1 fehérje valóban hordozza-e az S264G mutációt az AR vonalakban, megszekvenáltuk a fehérjének a mutációt is kódoló DNS szakaszát. Valamennyi megszekvenált rezisztens vonal AR, ARF2 és ARF6 D1 fehérjéje hordozta a mutációt, mely a $\operatorname{Ser}_{264} \rightarrow$ Gly aminosav cseréért felelös, míg a szenzitív vonalakban (AS, ASF2, ASF6) ugyanabban a pozícióban szerin volt kódolva. A reciprok keresztezések ASF6 és ARF6 generációjával folytatott kísérletek igazolták, hogy a D1 mutáns biotípusban megfigyelt fluoreszcencia paraméterek különbségeit, beleértve az NPQ-t is, a kloroplasztisz genom határozza meg. 


\subsection{A vízdeficit hatásának összehasonlító vizsgálata $S$. nigrum kétféle biotípusában és a különböző növénynemzedékekben}

\subsubsection{A vizdeficit hatása a növények vízállapotára és a gázcseréjére}

A továbbiakban a vízhiány (szárazság) fotoszintézisre gyakorolt hatásának összehasonlítását mutatom be $S$. nigrum AS és AR biotípusaiban. A szárazság napjainkban igen fontos környezeti tényezővé vált, amely a növekedés gátlását eredményezi a fotoszintézis limitálása révén. A vetés utáni kb. 40-42. napon, amikor a növényeket jó vízellátású kontroll állapotúnak definiáltuk, egy részüktöl megvontuk az öntözést. A növények vízállapotát és gázcseréjét jellemző paraméterek alapján három szakaszt különítettünk el a vízhiány időbeni vizsgálata során: enyhe szárazság (5-7 nap vízmegvonást követően), közepes szárazság (13-15 nap), és erős szárazság (18-19 nap), melyeket DH1 (dehydration state 1), DH2 (dehydration state 2), és DH3 (dehydration state 3) jelöléssel illettük. A vízmegvonás különböző szakaszaiban a növények egy részét a rehidráció után tovább vizsgáltuk, és RH1, RH2 vagy RH3 (rehydration sate 1, 2 és 3) jelöléssel illettük (lásd: Anyag és Módszer fejezet).

A sztómasürüség a levél abaxiális felületén kissé különbözött a jó vízellátású kontroll AS és AR szülő biotípusokban ( $28 \pm 4 \mathrm{~mm}^{-2}$ és $\left.20 \pm 4 \mathrm{~mm}^{-2}\right)$. A progresszív vízdeficit hatására a sztóma vezetőképesség $\left(\mathrm{g}_{\mathrm{s}}\right)$, a levél vízpotenciál ( $\Psi$ ) és a levél relatív víztartalom (RWC) értékei csökkentek (14. a, b ábrák és 8. táblázat). A $\mathrm{g}_{\mathrm{s}}$ és a $\Psi$ paraméterek értékei (kb. 490 $\mathrm{mmol} \mathrm{m} \mathrm{s}^{-2} \mathrm{~s}^{-1}$ es -0,34 MPa) közel azonosak voltak a kontroll biotípusokban (14. a és b. ábrák), és az RWC (kb. 91\%) szintén nem különbözött az AS és AR növényekben (8. táblázat). A vízmegvonást követö ötödik napon (DH1) eröteljes sztóma konduktancia csökkenés mutatkozott mindkét biotípusban (14. a ábra). A sztómazáródás mértéke szignifikánsan nagyobbnak bizonyult az AS, mint az AR típusban (14. a ábra), miközben az RWC (kb. 90\%) és a $\Psi(-0,38 \mathrm{MPa})$ értékekben még nem mutatkozott változtás a kontrollokhoz képest (8. táblázat és 14 . b ábra). Majd a vízhiány további szakaszában a drasztikus $g_{s}$ csökkenést a $\Psi$ csökkenése is követte. Azonban az AR típusban a $g_{s}$ és $\Psi$ csökkenése lassabban és kevésbé kifejezetten valósult meg, mint az AS párjában A vízdeficit DH2 (13-15 nap) szakaszában az RWC értékeiben jelentős visszaesés történt, mely hasonló mértékủ volt (60-80\%) a kétféle biotípusban, a $\mathrm{g}_{\mathrm{s}}$ értékek mindkét biotípusban a nullát közelítették, a $\Psi$ értékei pedig elérték a 
-2,5 MPa-t. A DH3 szakaszban a levelek fonnyadtsága miatt a vízpotenciál mérése már nem volt kivitelezhetö, a $\mathrm{g}_{\mathrm{s}}$ értéke nulla volt, a RWC értékei a kétféle biotípusban hasonló mértékben 30-55\%-ra csökkentek (8. táblázat).
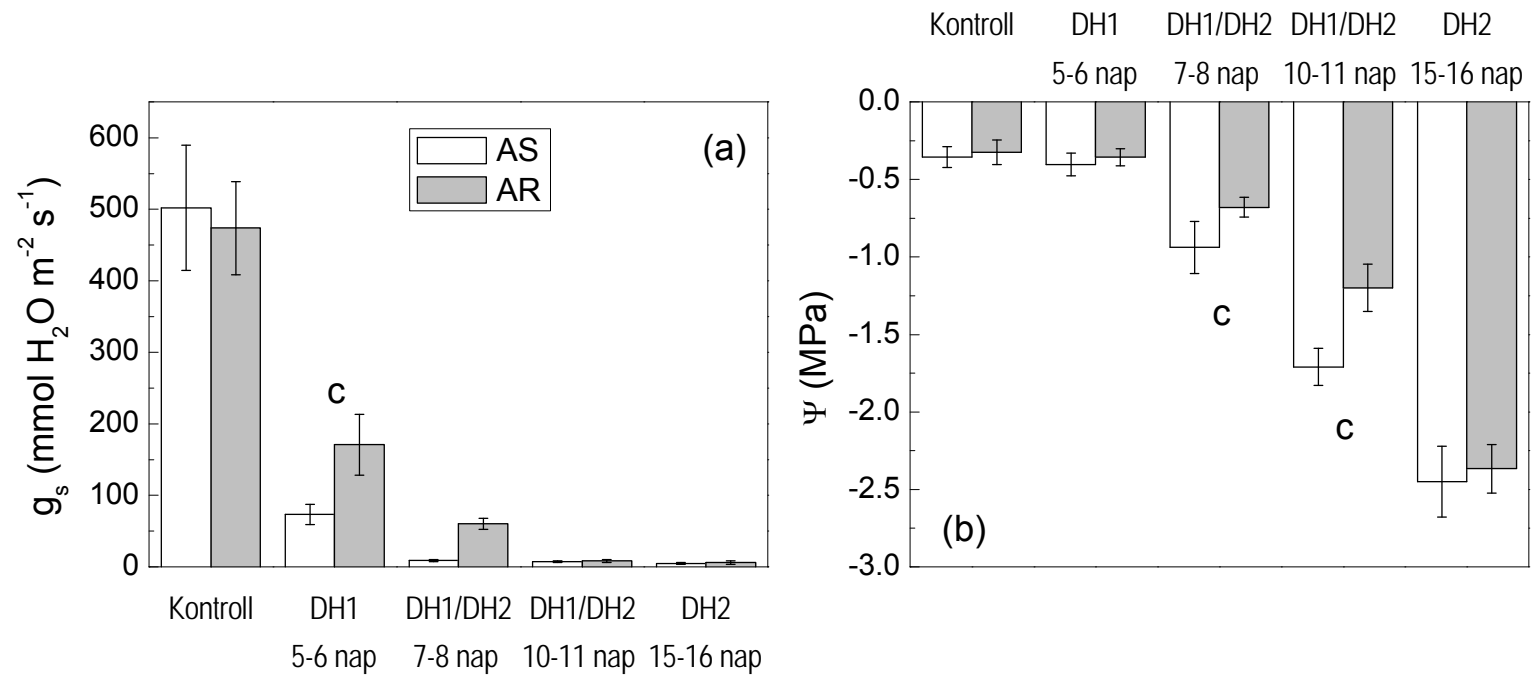

14. ábra $A$ vízmegvonás hatása a sztóma konduktanciára $\left(g_{s}\right)$ (a) és a levél vízpotenciáljára ( $\Psi$ ) (b) S. nigrum $A S$ (üres oszlop) és AR (teli oszlop) biotípusaiban. Az adatok három független kísérletböl 9-11 ismétlés átlagai $\pm S D$. A “c” szignifikáns eltérést jelöli a két biotipus között 5\%-os tévedési valószinüségi szinten.

8. táblázat $A$ relatív víztartalom alakulása a $S$. nigrum $A S$ és $A R$ biotípusában

\begin{tabular}{lcccc}
\hline & \multicolumn{4}{c}{ Relatív víztartalom alakulása a vízhiány hatására (\%) } \\
\hline Biotípus & Kontroll & DH1 (5-7 nap) & DH2 (13-15 nap) & DH3 (18-19 nap) \\
\hline AS & $91,6 \pm 1,8$ & $89,0 \pm 2,3$ & $60-80$ & $30-55$ \\
AR & $91,4 \pm 1.3$ & $90,1 \pm 2,4$ & $60-80$ & $30-55$ \\
\hline
\end{tabular}

A napok a vizmegvonás időtartamát jelölik a vízhiány egyes szakaszaiban 
A szárazság elsődleges célpontjai közé tartozik a fotoszintézis. A 15. ábrán jó vízellátású kontroll, vízhiányos (DH1 és DH2) és rehidratált (RH2) S. nigrum növények intakt levelein meghatározott $\mathrm{CO}_{2}$ asszimiláció (A) fényintezitás függését láthatjuk. A méréseket fotorespirációs és nem-fotorespirációs körülmények között végeztük (360 $\mu \mathrm{mol} \mathrm{CO} \mathrm{Col}^{-1}$, és $21 \%$ illetve $1 \% \mathrm{v} / \mathrm{v}_{2}$ ). A két, jó vízellátású kontroll AS és AR szülő biotípusban nem tapasztaltunk szignifikáns eltéréseket a maximális asszimilációs rátákban $\left(\mathrm{A}_{\max }\right)$ még nemfotorespirációs körülmények között sem (15. a és b ábrák). A kétféle biotípus fénylégzésének sebessége (15. c ábra), mely az $1 \%$ és $21 \% \quad \mathrm{O}_{2}$ tartalmú levegőben meghatározott asszimilációs ráták különbségéből számolható, sem tért el szignifikánsan egymástól. A vízhiány a sztómák záródásához vezet (14. a ábra), ami a $\mathrm{CO}_{2}$ fixáció mértékének csökkenését eredményezte mindkét biotípusban (15. d és e ábrák). Az AR növény fotoszintézisének intenzitása a DH1 szakaszban magasabbnak bizonyult (15. d és e ábrák) a fényintenzitás növekedésével, mint az AS párjáé. A fénylégzés intenzitásának fénytelítési értékei közel azonosak maradtak a kontrollokéhoz képest (15. f ábra), tehát a fénylégzés mértéke a kisebb $\mathrm{CO}_{2}$ megkötés sebessége mellett megemelkedett. A közepes fokú szárazság esetén (DH2) a $\mathrm{CO}_{2}$ asszimiláció intenzitásában további esést figyelhettünk meg mindkét biotípusban (15. g és h ábrák), és az AR továbbra is némileg felülmúlja a vad AS típust. A fotorespiráció abszolút értékeiben csökkenést tapasztaltunk mindkét biotípusban (kontrollok és DH1-hez képest 15. i ábra). A vízhiány harmadik szakaszában (DH3) mérhető sztóma konduktancia és $\mathrm{CO}_{2}$ asszimiláció már nem volt észlelhető. A vízhiány egyes szakaszaiban a növények egy részét rehidratáltuk, és 24 óra elteltével azt tapasztaltuk, hogy a $\mathrm{CO}_{2}$ fixálás sebessége enyhén növekedett, illetve részlegesen visszaállt (15. j és $\mathrm{k}$ ábrák, RH2). A növények fotorespirációjának számított sebességei az RH2 állapotú növényekben alacsonyabbak voltak mind a DH2, mind a kontrollokhoz képest, és közel azonos értékeket vettek fel a kétféle rehidratált biotípusban (15. 1 ábra). Mialatt a fotorespiráció intenzitásának abszolút értékei a vízmegvonás hatására csökkentek a kontrollokéhoz képest, a fotorespiráció mértéke, vagyis a Rubisco enzim által katalizált oxigenáció a karboxilációhoz viszonyítva megemelkedett. 

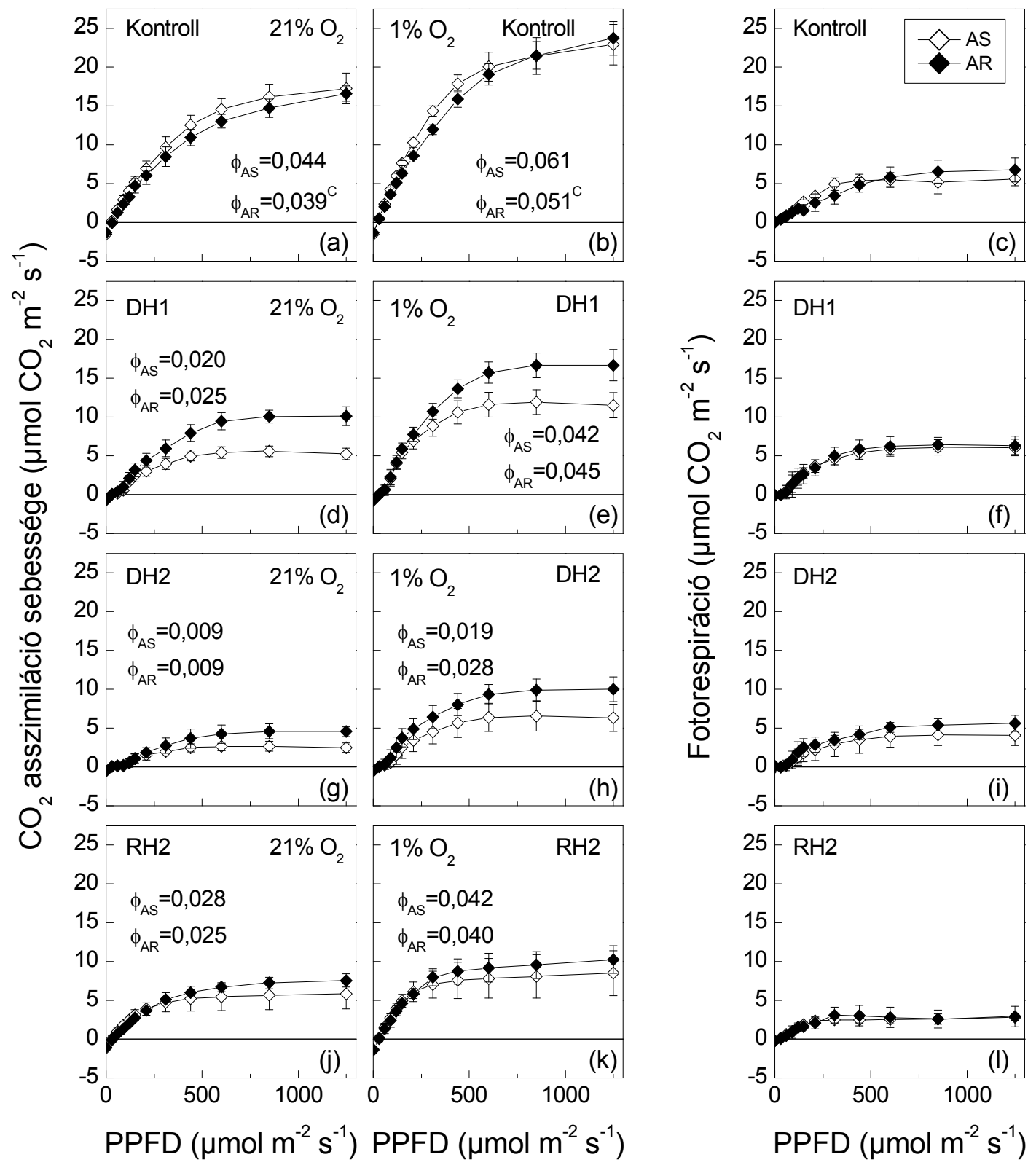

15. ábra $\mathrm{A} \mathrm{CO}_{2}$ asszimiláció (A) és a fénylégzés sebességének fényintenzitás függése progresszív vízmegvonás és rehidráció alatt $360 \mu \mathrm{mol} \mathrm{CO}_{2} \mathrm{~mol}^{-1}$ koncentráció mellett és 25 $28^{\circ} \mathrm{C}$ hömérsékleten. $a, d, g, j, 21 \% v / v \mathrm{O}_{2} ; b, e, h, k,: 1 \% v / v \mathrm{O}_{2} ; c, f, i, l$, fotorespiráció számitott értékei (A $\left.A_{1 \%}-A_{21 \%}\right), A S$, a S. nigrum vad biotípusa (üres szimbólum); $A R, a S$. nigrum D1 mutáns biotípusa (teli szimbólum). Kontroll: jó vízellátású; DH1: enyhe szárazság; DH2, közepes szárazság; RH2: rehidratált DH2-böl. ф, a fotoszintézis relatív hatásfoka, a görbe lineáris szakaszának kezdeti meredekségéböl számolva. Az adatok három független kisérletböl 5-7 ismétlés átlagai $\pm S D$. A “c” szignifikáns eltérést jelöli a két biotípus között 5\%-os tévedési valószínüségi szinten. 
Míg a kontroll és a rehidratált növényekben a fotorespiráció mértéke kb. 26-31\%-os volt mindkét biotípusban, addig a DH1 és DH2 szakaszokban jelentősen magasabb értékeket kaptunk, ez rendre kb. 53\% és 38\%-nak adódott az AS és AR típusokban gyenge vízhiány esetén (DH1), illetve 62\% és 55\%-nak a DH2 szakaszban.

A kontroll AR típusban a látszólagos kvantumhatásfok $(\phi)$, vagyis a görbe kezdeti meredeksége (kb. 15\%-kal) alacsonyabb volt, mint az AS párjában (15. a és b ábrák). A vízhiány alatt (DH1 és DH2) a $\phi$ csökkenését figyelhettük meg mindkét biotípusban (15. d, e, g és h ábrák). Nem-fotorespirációs feltételek mellett az AR magasabb hatásfokkal bírt (15. e és h ábrák), mint az AS párja, míg fotorespirációs körülmények között ezek közel azonosak voltak (15. d és g ábrák) a kétféle biotípusban a DH1 és a DH2 szakaszokban. A növények rehidratálása után 24 órával a hatásfokok jelentősen megemelkedtek a vízhiányos állapothoz képest, és hasonló értékeket vettek fel a kétféle biotípusban (15. j és k ábrák).

A sejtek közötti, intercelluláris $\mathrm{CO}_{2}$ koncentráció $\left(\mathrm{C}_{\mathrm{i}}\right)$ függvényében meghatározott $\mathrm{CO}_{2}$ asszimiláció ( $\mathrm{A} / \mathrm{C}_{\mathrm{i}}$ görbe) hasznos indikátor lehet a vízhiány fotoszintézisre gyakorolt hatásának tanulmányozásában. A $800 \mu \mathrm{mol}$ foton $\mathrm{m}^{-2} \mathrm{~s}^{-1}$ levélfelületre beeső fényintenzitás mellett meghatározott $\mathrm{A} / \mathrm{C}_{\mathrm{i}}$ görbék azonosak voltak az AS és az AR szülő biotípusokban (16. a ábra). $\mathrm{Az} \mathrm{A} / \mathrm{C}_{\mathrm{i}}$ görbe kezdeti meredeksége $(\varepsilon)$, mely a Rubisco enzim aktivitására és/vagy extrahálható mennyiségére jellemző érték (karboxilációs hatékonyság), megegyezett a kétféle kontroll biotípusban (16. a ábra). A vízhiány (DH1 és $\mathrm{DH} 2$ ) az $\varepsilon$ értékeket negatívan befolyásolta, azonban az AR esetében jelentősen kisebb mértékü csökkenés mutatkozott, mint az AS párjában (16. b és c ábák). $\mathrm{Az} A / \mathrm{C}_{\mathrm{i}}$ görbe kezdeti szakaszát követően, a magasabb $\mathrm{C}_{\mathrm{i}}$ értékeknél a RuBP regenerációjának sebessége $\left(\mathrm{J}_{\max }\right)$ és az inorganikus foszfát $\left(\mathrm{P}_{\mathrm{i}}\right)$ elérhetősége válik az asszimiláció sebességének meghatározójává. A progresszív vízhiány mindkét biotípusban szignifikánsan csökkentette a RuBP regenerációjának sebességét (16. b és c ábrák). Az adatok további analízise során megvizsgáltuk a vízhiány hatását a látszólagos karboxilációs hatásfok $\left(\mathrm{C}_{\mathrm{i}} / \mathrm{C}_{\mathrm{a}}\right)$ és a sztóma konduktancia $\left(\mathrm{g}_{\mathrm{s}}\right)$ értékeire légköri $\mathrm{CO}_{2}$ koncentráció $\left(\mathrm{C}_{\mathrm{a}}\right)$ függvényében (17. ábra). $A \mathrm{C}_{\mathrm{i}} / \mathrm{C}_{\mathrm{a}}$ és a $\mathrm{g}_{\mathrm{s}}$ a kétféle kontroll biotípusban nem különböztek (17.a ábra). A g tranziensen emelkedett kb. $300 \mu \mathrm{mol} \mathrm{CO}_{2} \mathrm{~mol}^{-1}$ koncentrációig majd egy gyors csökkenés (600 $\mu \mathrm{mol} \mathrm{CO}_{2}$ mol$^{-1}$ koncentrációig) után egy lassabb csökkenés következett a legmagasabb $\mathrm{C}_{\mathrm{a}}$ értékig (17. a ábra, $\mathrm{g}_{\mathrm{s}}$ ). $\mathrm{A} \mathrm{C}_{\mathrm{i}} / \mathrm{C}_{\mathrm{a}}$ arány egy enyhe visszaesés után felvette a kb. 0,75 értéket, mely közel állandó maradt mindkét biotípusban (17. a ábra). 

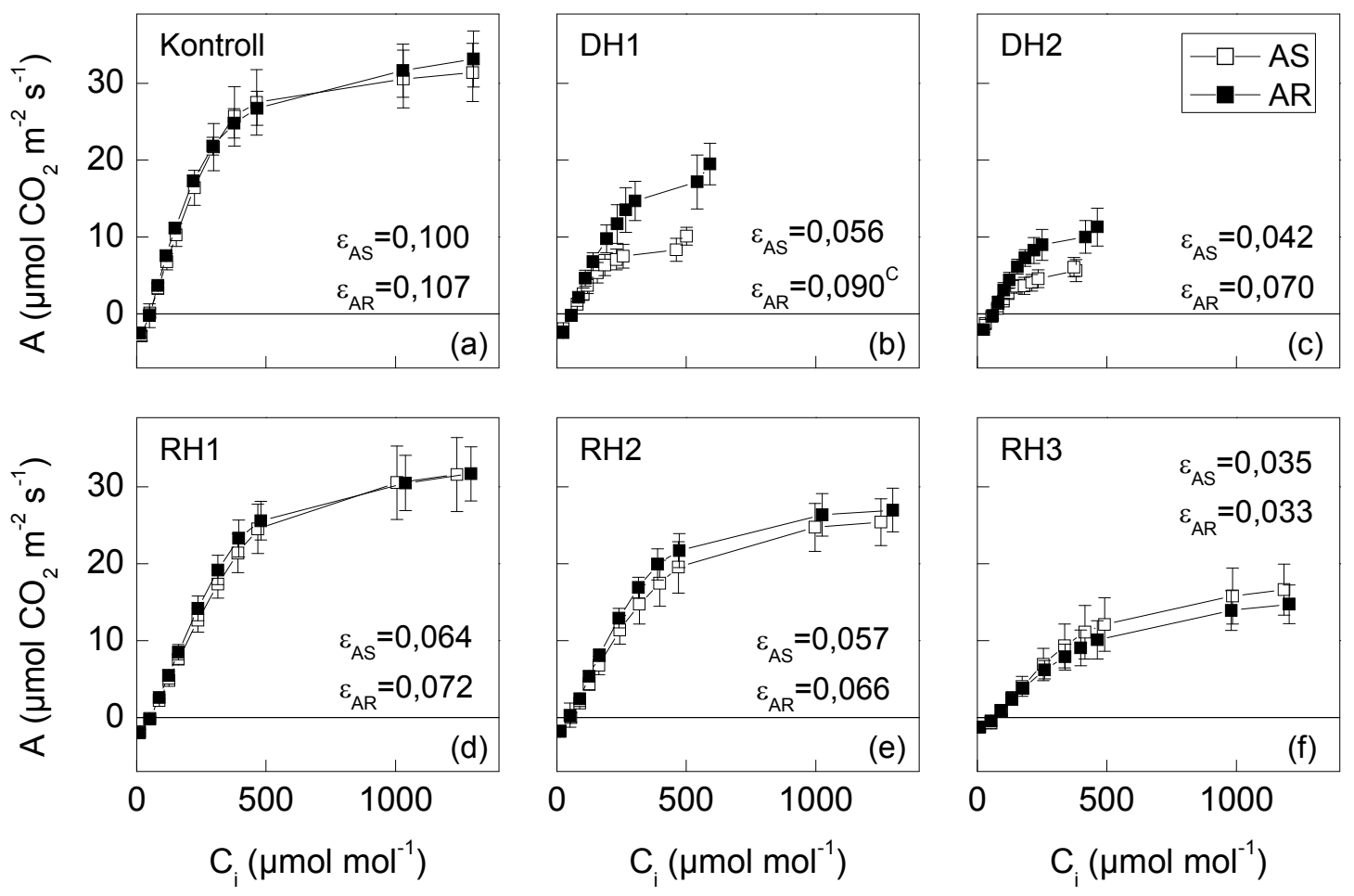

16. ábra $\mathrm{A} \mathrm{CO}_{2}$ asszimilációs ráta (A) az intercelluláris $\mathrm{CO}_{2}$ koncentráció $\left(C_{i}\right)$ függvényében. $A S$, a S. nigrum vad biotipusa (- $\square-)$; AR, a S. nigrum D1 protein mutáns biotípusa (-口-). Kontroll: jó vízellátású; DH1: enyhe szárazság; DH2, közepes szárazság; RH1, RH2 és RH3: rehidratált növény a DH1, DH2 és DH3 szakaszból. A méréseket LCpro+ IRGA készülékkel végeztük, a levélfelületen a beesö fényintenzitás $800 \mu \mathrm{mol}$ foton $\mathrm{m}^{-2} \mathrm{~s}^{-1}$, a levélkamra hömérséklete $25-28^{\circ} \mathrm{C}$ volt. $\varepsilon$, a Rubisco enzim aktivitása és/vagy extrahálható mennyisége, mely a görbe lineáris szakaszának kezdeti meredeksége. Az adatok három független kísérletböl 5-7 ismétlés átlagai $\pm S D$. A “c” szignifikáns eltérést jelöli a kétféle biotípus között 5\%-os tévedési valószinüségi szinten.

A vízhiány a sztómazáródás inicializálása által csökkentette a sztóma vezetőképességet, így a $\mathrm{C}_{\mathrm{i}} / \mathrm{C}_{\mathrm{a}}$ arányt is (17. b és c ábrák). Enyhe vízhiány esetén (17. b ábra, $\left.\mathrm{DH} 1\right)$ a biotípusok közötti különbség jól észlelhető az AR típus javára. Az idő elörehaladtával (17. c ábra, DH2) a csökkenés folytatódott, és a kétféle biotípus között fennálló különbség mérséklődött illetve el 
is tünt. A növényeknek a szárazság különböző szakaszaiból történő rehidratálása (RH1, RH2 és RH3) után a helyreállási folyamatoknak köszönhetően mindkét biotípusban emelkedni kezdett a $\mathrm{CO}_{2}$ asszimiláció intenzitása, azonban csak részleges helyreállást tapsztaltunk a $\mathrm{J}_{\max }$ értékében a magas intercelluláris $\mathrm{CO}_{2}$ koncentrációknál (16. d, e és f ábrák). A 17. d, e és $\mathrm{f}$ ábrák azt mutatják, hogy a $\mathrm{C}_{\mathrm{i}} / \mathrm{C}_{\mathrm{a}}$ arány csaknem teljesen helyreállt, és elérte a kontroll növényekre jellemző értékeket mindkét biotípusban, a $\mathrm{g}_{\mathrm{s}}$ helyreállása azonban csak részlegesen valósult meg.
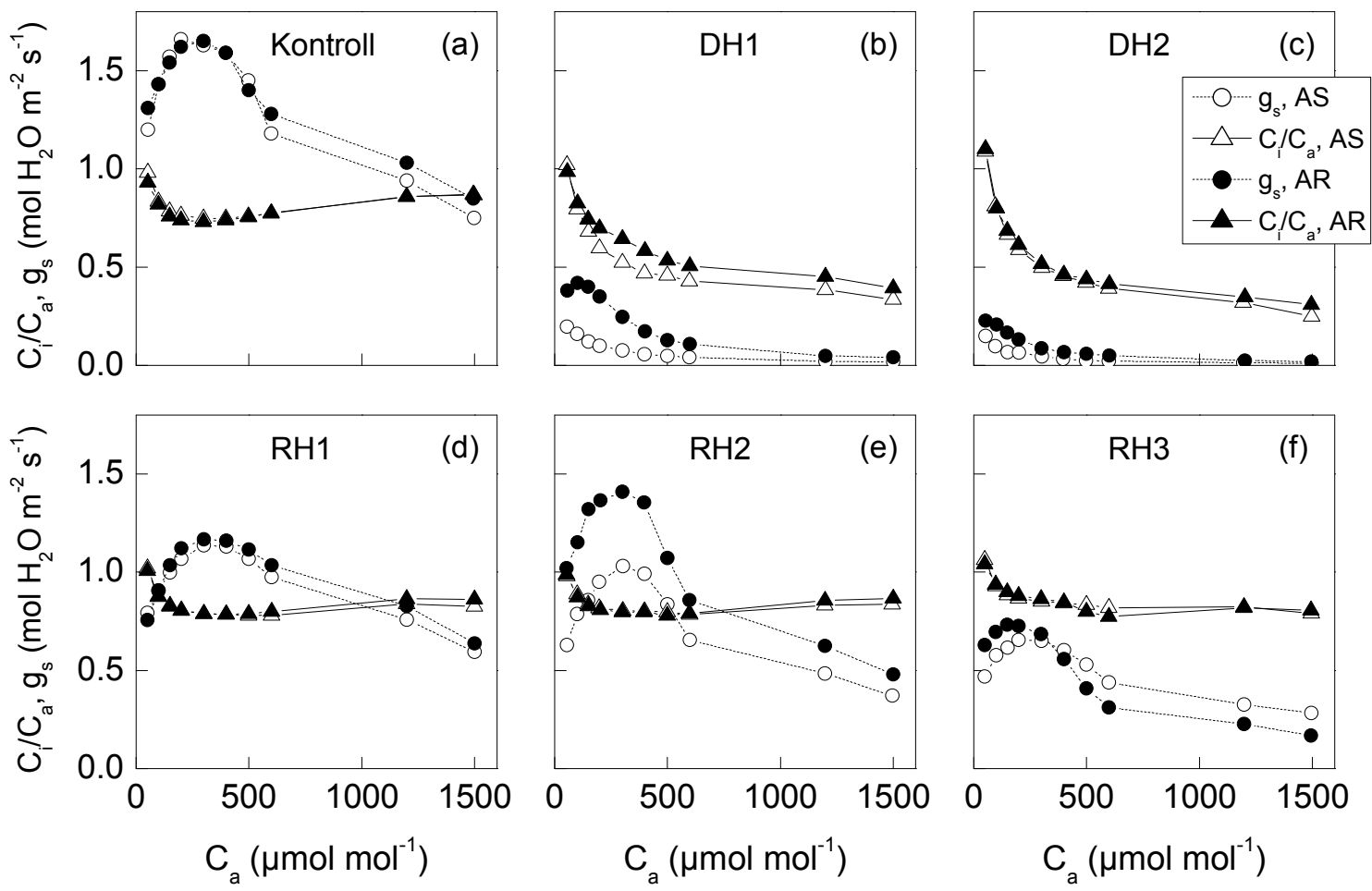

17. ábra A látszólagos karboxilációs hatásfok $\left(C_{i} / C_{a}, \triangle\right.$ és $\boldsymbol{\Lambda}$, az AS és az AR biotípusokban) és a sztóma konduktancia ( $g_{s}, \bigcirc$ és $\bigcirc$, az AS és az AR biotípusokban) válaszgörbék a légköri $\mathrm{CO}_{2}$ koncentráció $\left(C_{a}\right)$ függvényében $S$. nigrum leveleiben. Kontroll: jó vízellátású; DH1: enyhe szárazság; DH2, közepes szárazság; $R H 1$, RH2 és RH3: rehidratált növény a DH1, DH2 és DH3 szakaszból. A méréseket LCpro+ IRGA készülékkel végeztük, a levélfelületen a beesö fényintenzitás $800 \mu \mathrm{mol}$ foton $\mathrm{m}^{-2} \mathrm{~s}^{-1}$, a levélkamra hömérséklete 25-28 C. Az adatok három független kísérletből 5-7 ismétlés átlagai. 
Választ kerestünk arra, hogy a $S$. nigrum szülö AR biotípusának a vízállapot és a gázcsere szempontjából mutatott toleránsabb viselkedése a vízhiánnyal szemben a D1 fehérje mutációjához köthető-e, ezért vizsgálatokat folytattunk a reciprok keresztezésekböl származó hibrid növényekkel is. A gázcsere vizsgálatok alapján megállapítottuk, hogy a szülő biotípusok közötti, a vízhiány alatt fennálló különbség eltünt az F2 hibridek AS és AR típusai között (ASF2 és ARF2). Mind a fotoszintetikusan aktív fényre adott válaszgörbék (18. ábra), mind az $\mathrm{A} / \mathrm{C}_{\mathrm{i}}$ görbék esetében (9. táblázat) az ASF2 és ARF2 jó vízellátású kontrollok értékei szinte azonosak voltak a szülökéivel. A vízhiány (DH1 és DH2) által indukált csökkenés szinte azonos mértékủ volt az F2 hibridek kétféle biotípusában, mely értékek a vízhiánynak kitett AR szülő értékeit közelítették. Az adatok további analízise során a $g_{s}$ és a $C_{i} / C_{a}$ paraméterek is azt mutatták, hogy a kétféle szülő biotípusban tapasztalt különbségek elmosódtak az F2 nemzedékben (adatok nincsenek bemutatva). Ugyanezt a megállapítást tehetjük a sztómasürüség vizsgálatokkal kapcsolatban is $\left(24 \pm 8 \mathrm{~mm}^{-2}\right.$ és $25 \pm 7 \mathrm{~mm}^{-2}$ az ASF2 és ARF2ben).

9. táblázat $A$ S. nigrum szülö és F2 hibridek $J_{\max }$ értékeinek összehasonlitása

\begin{tabular}{|ccc||ccc|}
\hline Biotípus & Kezelés & $\begin{array}{c}\mathrm{J}_{\max } \\
\left(\mu \mathrm{mol} \mathrm{m}^{-2} \mathrm{~s}^{-1}\right)\end{array}$ & $\begin{array}{c}\mathrm{J}_{\max } \\
\left(\mu \mathrm{mol} \mathrm{m}^{-2} \mathrm{~s}^{-1}\right)\end{array}$ & Kezelés & Biotípus \\
\hline \multirow{4}{*}{$\mathrm{AS}$} & Kontroll & $31,40 \pm 3,77$ & $29,59 \pm 4,07$ & Kontroll & \\
& $\mathrm{DH} 1$ & $10,11 \pm 1,16$ & $18,91 \pm 2,31$ & $\mathrm{DH} 1$ & \\
& $\mathrm{DH} 2$ & $6,10 \pm 1,24$ & $11,30 \pm 1,81$ & $\mathrm{DH} 2$ & $\mathrm{ASF} 2$ \\
& $\mathrm{RH} 1$ & $31,61 \pm 4,82$ & $30,98 \pm 3,67$ & $\mathrm{RH} 1$ & \\
& $\mathrm{RH} 2$ & $25,41 \pm 3,04$ & $22,17 \pm 2,79$ & $\mathrm{RH} 2$ & \\
& $\mathrm{RH} 3$ & $16,64 \pm 3,32$ & $16,12 \pm 2,07$ & $\mathrm{RH} 3$ & \\
$\mathrm{AR}$ & $\mathrm{Kontroll}$ & $33,15 \pm 3,77$ & $29,36 \pm 3,58$ & $\mathrm{Kontroll}$ & \\
& $\mathrm{DH} 1$ & $19,51 \pm 2,70^{\mathrm{b}}$ & $19,94 \pm 3,94$ & $\mathrm{DH} 1$ & \\
& $\mathrm{DH} 2$ & $11,31 \pm 2,47^{\mathrm{c}}$ & $10,54 \pm 1,91$ & $\mathrm{DH} 2$ & $\mathrm{ARF} 2$ \\
& $\mathrm{RH} 1$ & $31,74 \pm 3,50$ & $31,55 \pm 2,71$ & $\mathrm{RH} 1$ & \\
& $\mathrm{RH} 2$ & $26,98 \pm 2,84$ & $21,65 \pm 1,49$ & $\mathrm{RH} 2$ & \\
& $\mathrm{RH} 3$ & $14,75 \pm 2,51$ & $15,04 \pm 1,89$ & $\mathrm{RH} 3$ & \\
\hline
\end{tabular}

AS és AR, ASF2 és ARF2 a S. nigrum szülö vad és D1 mutáns, F2 nemzedék vad és D1 mutáns biotípusai. A szülö AS és AR adatok a 16. ábra adataiból származnak. A kezelések, mérési körülmények, mérési eljárás ugyanazok, mint a 16. ábrán. A " $b$ és c" szignifikáns eltérést jelölik a két biotipus között 1 és 5\%-os tévedési valószinüségi szinten 


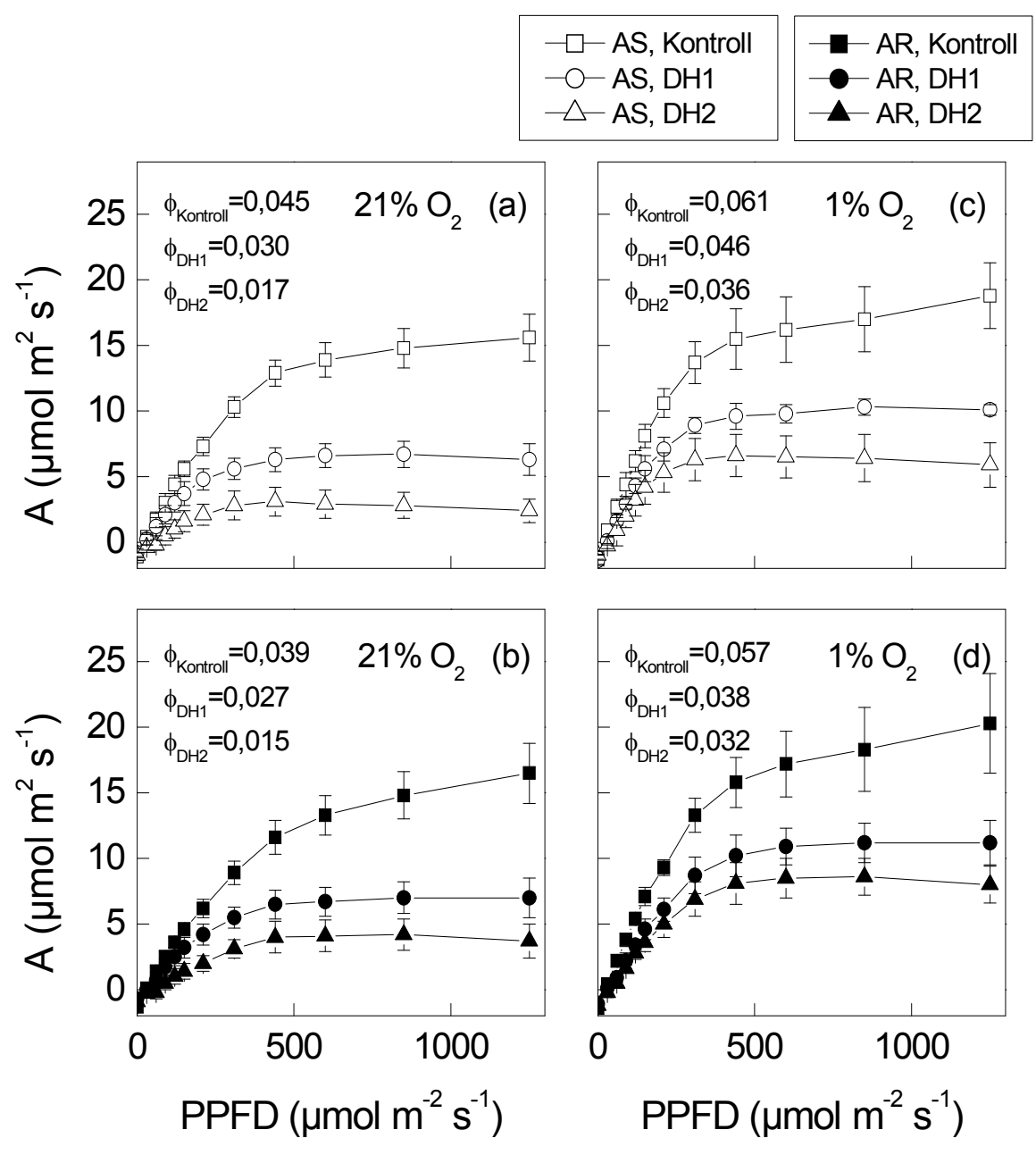

18. ábra $\mathrm{A} \mathrm{CO}_{2}$ asszimilációs ráta (A) aktinikus fényre adott válaszgörbéi progressziv vízhiány alatt. a és $b, 21 \%$ v/v $\mathrm{O}_{2} ; c$ és $d, 1 \%$ v/v $\mathrm{O}_{2} ; 360 \mu \mathrm{mol} \mathrm{CO}_{2} \mathrm{~mol}^{-1}$ koncentráció mellett és 25-28 C hömérsékleten. ASF2, a S. nigrum vad-biotípusú F2 hibridje (üres szimbólum); ARF2, a S. nigrum D1 protein mutáns biotípusú F2 hibridje (teli szimbólum). Jó vízellátású kontroll, $-\square-$ és - - -; DH1: enyhe szárazság, -O- és - -; DH2, közepes szárazság, $-\triangle-$ és $-\mathbf{\Delta}-$. $\phi$, látszólagos kvantumhatásfok, a görbe lineáris szakaszának kezdeti meredeksége. Az adatok 5-7 ismétlés átlagai $\pm S D$. 


\subsubsection{A vizdeficit hatása az elnyelt fényenergia fotokémiai hasznositására}

A gyenge (DH1) illetve a közepes (DH2) vízhiány szakaszaiban a PSII-re jellemző funkcionális fluoreszcencia kioltási paraméterekben nem tapasztaltunk változást a jó vízellátású kontrollokhoz képest. Változások az erős szárazságnak (DH3) kitett növények esetében léptek fel először.

Az erős vízhiány (DH3) hatására mind az NPQ mind az 1 - qP megemelkedtek a jó vízellátású kontrolljaikhoz képest valamennyi növényvonalban (19. a, b, és 8. a, 5. c ábrák). Az NPQ a kétféle vízhiányos biotípusban azonos sebességgel nőtt a fényintenzitás növekedésével, az AR vonalak (AR, ARF2, ARF6) közel telítési fényintenzitáson enyhén felülmúlták AS párjaikat (AS, ASF2, ASF6) (19. a ábra). A $J_{\mathrm{ETR}}$ és a $\Phi_{\mathrm{PSII}}$ aktinikus fényre adott válaszgörbéi alapján megállapíthatjuk, hogy ezek a jó vízellátású kontrolljaikhoz képest (10. a és b ábrák) az erős szárazság hatására közel azonos értékekre estek vissza a kétféle biotípusban (20. a és b ábrák). Fontos megvizsgálnunk, hogy míg a jó vízellátású kontroll AR vonalakban a $\Phi_{\mathrm{PSII}}, \mathrm{J}_{\mathrm{ETR}}$ és NPQ (10. a, b és 8 . a ábrák) szignifikánsan alacsonyabbak voltak a növekvő fényintenzitások mellett, és a PSII-re ható gerjesztési nyomás (1 - qP) (5. c ábra) szignifikánsan magasabbnak bizonyult, mint az AS párjaikban, addig az erős szárazság következtében jelentősen megváltozott ez a kép (20. a, b és 19 a, b ábrák). Míg az alacsonyabb NPQ kapacitással rendelkező kontroll AR típusban szignifikánsan magasabb volt a PSII-re ható gerjesztési nyomás, addig ez az erős szárazság hatására közel azonos értékekre emelkedett a kétféle biotípusban és hibridjeikben a kontrollokhoz képest (19. b ábra). A vízhiány az NPQ növekedését indukálta, amely kb. 18\%-os és igen drasztikus, kb. 250\%-os volt közel telítési fényintenzitáson az AS és az AR vonalakban a jó vízellátású kontrolljaikhoz képest (19. a és 8. a ábrák). Tehát, míg a kontroll AR vonalak kb. 55\%-kal alacsonyabb NPQ kapacitással bírtak AS párjaikkal összehasonlítva közel telítési fényintenzitáson, addig az erős szárazságnak (DH3) kitett AR vonalak esetében ez a kép megfordult, és kb. 15\%-os emelkedést figyelhettünk meg az AS párjaikkal szemben. A szülö biotípus és a megfelelő hibridjei a vízhiányos mintákban sem mutattak különbségeket az általunk vizsgált paraméterek esetén. 

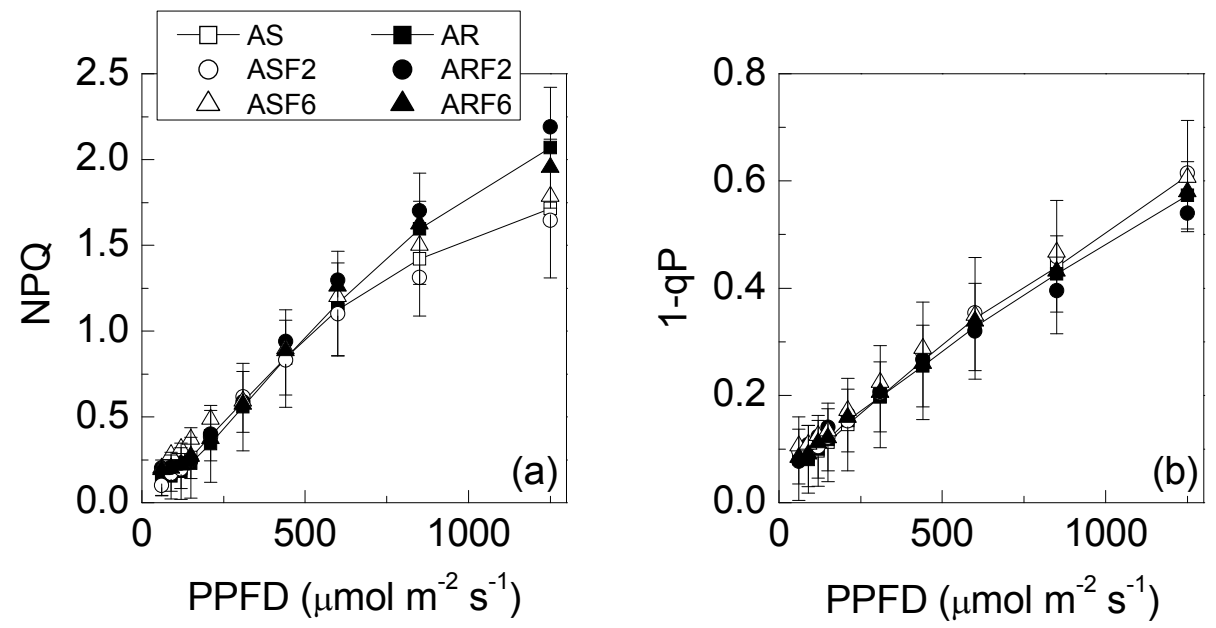

19. ábra Az erős szárazság (DH3) hatása a nem-fotokémiai kioltás (NPQ, a), és a PSII-re ható gerjesztési nyomás $(1-q P$, b) fényintenzitás függésére vad ( $A S$, üres szimbólum) és D1 mutáns (AR, teli szimbólum) S. nigrum vonalakban. AS és AR, szülö, - $\square$-és - -; ASF2 és ARF2, O és @; ASF6 és ARF6, $\triangle$ és $\mathbf{\Delta}$. Az adatok 12 ismétlés átlagai, $S D$ a szülö (AS és AR) populációban van feltüntetve.

Az erősen vízhiányos (DH3) növények esetében a $\Phi_{\text {PSII }}$ és a $J_{\text {ETR }}$ értékei gyakorlatilag nem különböznek a kétféle szülő biotípusban és hibridjeikben (20. a és b ábrák). A regulált energiadisszipáció hatásfokának $\left(\Phi_{\mathrm{NPQ}}\right)$ és sebességének $\left(\mathrm{J}_{\mathrm{NPQ}}\right)$ fokozódását figyelhetjük meg valamennyi vízhiányos $S$. nigrum vonalban a jó vízellátású kontrollokhoz képest (20. c, d és 10. c, d ábrák). A $\Phi_{\mathrm{NPQ}}$ és $J_{\mathrm{NPQ}}$ görbéi szinte azonosak voltak az AS és AR vonalakban. A nemregulált hődisszipáció hatásfoka $\left(\Phi_{\mathrm{NO}}\right)$ és sebessége $\left(\mathrm{J}_{\mathrm{NO}}\right)$ az AS vonalakban a vízhiány hatására megemelkedett a kontrollokhoz viszonyítva (20. e, f és 10. e, f ábrák). Az AR típusokban a $\Phi_{\mathrm{NO}}$ kismértékben növekedett a kontrollokhoz képest, azonban ezt egy csökkenő tendencia követte a fényintenzitás emelkedésével, és közel telítési fényintenzitáson a jó vízellátású kontroll értékeket közelítették. A $J_{\mathrm{NO}}$ a kontrollokéhoz képest szintén csökkenést mutatott az AR típusokban (20. e, f és 10. e, f ábrák). Statisztikailag nem mutatható ki szignifikáns különbség a vízhiányos AS és AR biotípusok és hibridjeik között egyik paraméter esetében sem (20. ábra). 

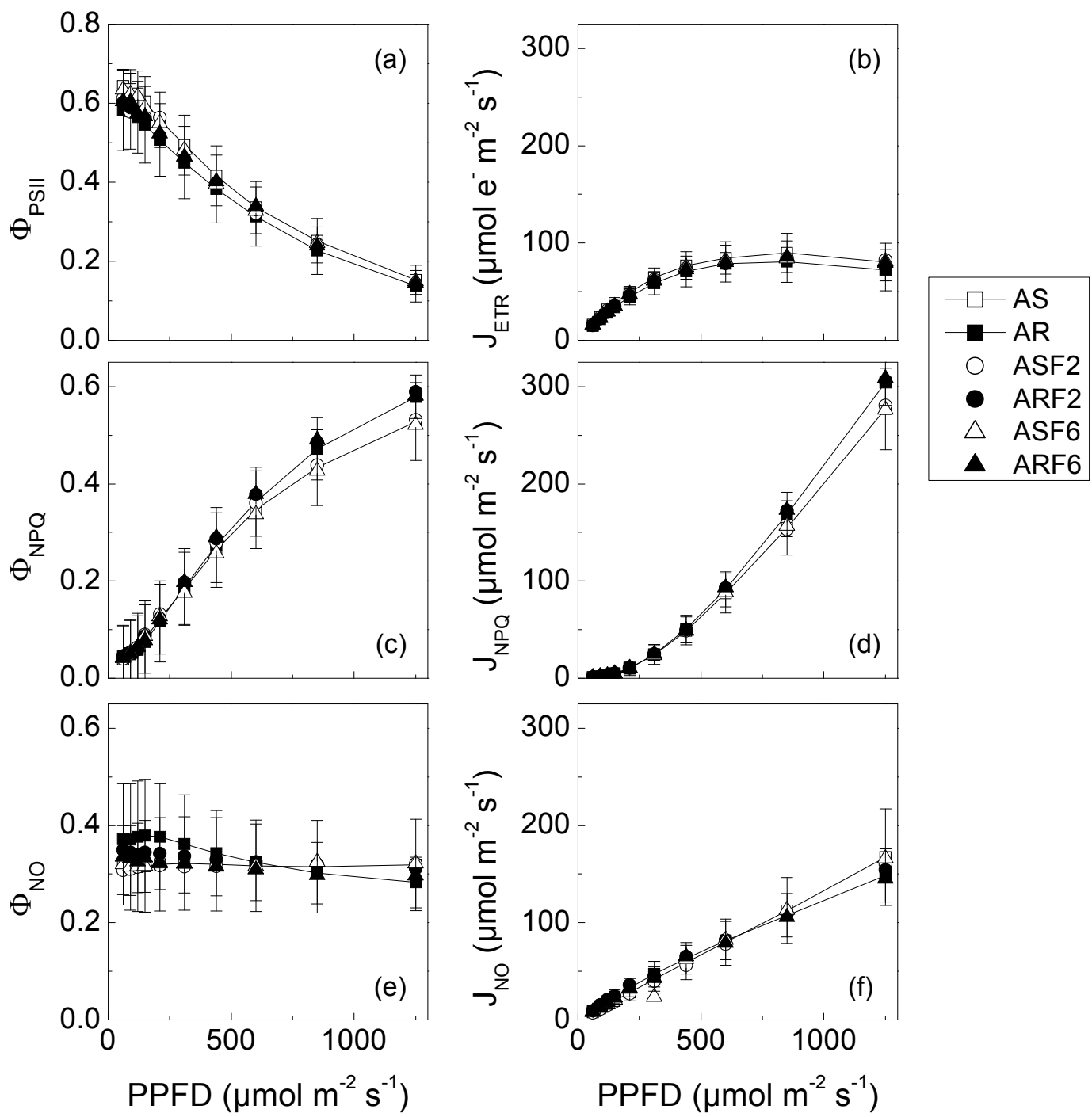

20. ábra Az erös szárazság (DH3) hatása a PSII komplementer hatásfokok és sebességeik aktinikus fényre adott válasz görbéire AS (üres szimbólum) és AR (teli szimbólum) $S$. nigrum biotípusok leveleiben, és hibridjeikben. AS és AR, szülö, $-\square-e ́ s$ -ם-; ASF2 és ARF2, ○ és О; ASF6 és ARF6, $\triangle$ és $\mathbf{\Delta}$. (a, b) fotokémiai energia konverzió $\Phi_{P S I} ;(c, d)$ regulált energia disszipáció $\Phi_{N P Q} ;(e, f)$ nem-regulált energia disszipáció $\Phi_{N O}$. Az adatok 12 ismétlés átlagai, a $S D$ a szülö (AS és AR) populációban van feltüntetve. 
Az AS és AR vonalakban a $\Phi_{\mathrm{NO}}$ elérte a kb. 0,3 értéket, amit a fényintenzitás emelkedése nem befolyásolt (20. e ábra). A konstitutív energia disszipáció sebességei $\left(\mathrm{J}_{\mathrm{NO}}\right)$ lineárisan emelkedtek szinte azonos sebességgel a kétféle biotípusban (20. f ábra). Összevetve a jó vízellátású kontrollok és az erős vízhiánynak (DH3) kitett növények ún. PSII komplementer hatásfokait, elmondhatjuk, hogy valamennyi vízhiányos AS biotípusban (AS, ASF2, ASF6) a fotokémiai hatásfok $\left(\Phi_{\mathrm{PSII}}\right) \mathrm{kb}$. 60\%-kal esett vissza közel telítési fényintenzitáson a jó vízellátású kontrolljaikhoz képest, azonban az AR vonalakban (AR, ARF2, ARF6) ez csupán kb. 45\%-ot jelentett. A kétféle biotípus a vízhiány hatására mintegy ugyanarra a szintre csökkent, azonban a kontroll AS vonalak szignifikánsan magasabb fotokémiai hatásfokkal bírtak, mint AR párjaik. Továbbá a regulált energia disszipáció frakciója $\left(\Phi_{\mathrm{NPQ}}\right)$ rendre kb. $40 \%$ és $50 \%$-kal emelkedett meg a vízhiányos AS és AR típusokban a jó vízellátású kontrolljaikhoz képest. Eközben a nem-regulált energia disszipáció a vízhiány hatására 33\%kal nőtt az AS típusban, míg 20\%-kal csökkent az AR vonalakban közel telítési fényintenzitáson.

A 21. ábra a három PSII komplementer hatásfok és az NPQ indukcióját (1250 $\mu \mathrm{mol}$ foton $\mathrm{m}^{-2} \mathrm{~s}^{-1}, 15$ perc) és sötétrelaxációját (10 perc) szemlélteti jó vízellátású kontroll, erősen vízhiányos (DH3) és rehidratált (RH3) S. nigrum vonalakban. Az AS és AR biotípusok között szignifikáns különbség adódott a $\Phi_{\mathrm{PSII}}$ értékeiben az AS vonalak javára a kontroll és a 24 órával a rehidratálás (RH3) után helyreállt növények esetében (21. a és c ábrák), míg az erős szárazságnak kitett növényekben közel azonos értékekre esik vissza a hatásfok (21. b ábra). Az NPQ és a $\Phi_{\mathrm{NPQ}}$ alakulásának összevetése során láthatjuk, hogy míg a kontroll és rehidratált (RH3) AR vonalak szignifikánsan alacsonyabb fotoprotektív NPQ kapacitással bírnak (21. g és i ábrák), a regulált energia disszipáció hatásfoka $\left(\Phi_{\mathrm{NPQ}}\right)$, mely a fényindukált fotoprotektív folyamatokkal van összefüggésben, a kétféle biotípusban gyakorlatilag megegyezik (21. d és $\mathrm{f}$ ábrák, kontroll és RH3), és a sötétben teljesen relaxál. 

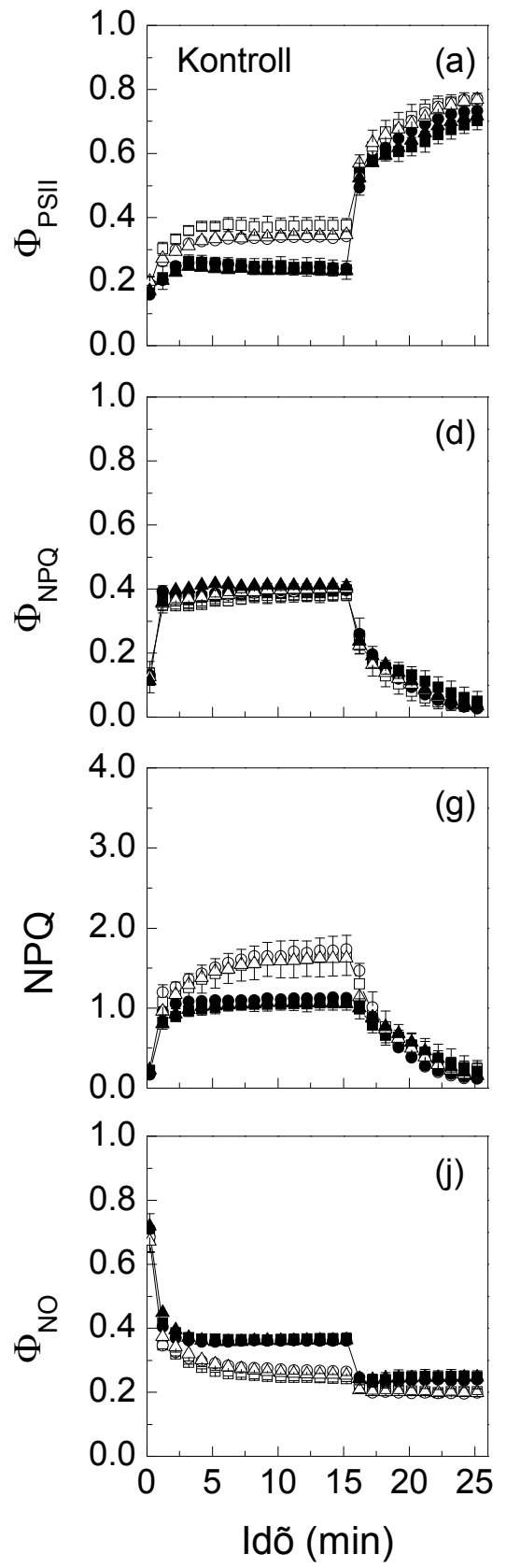
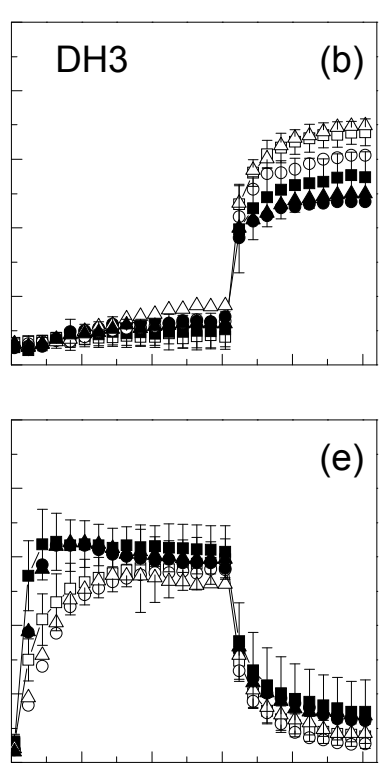

(e)

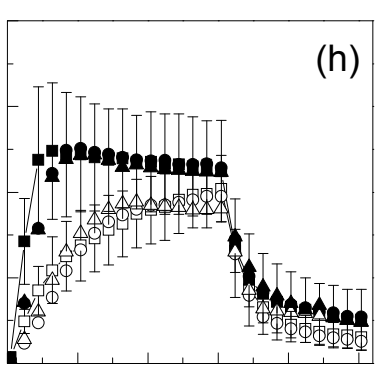

(h)

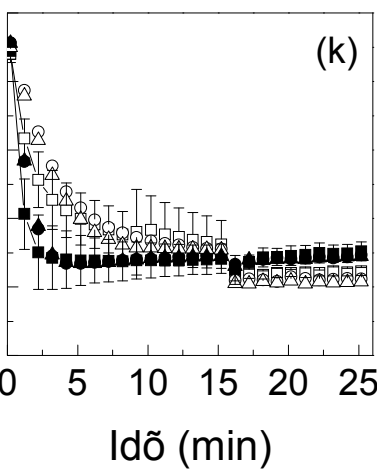

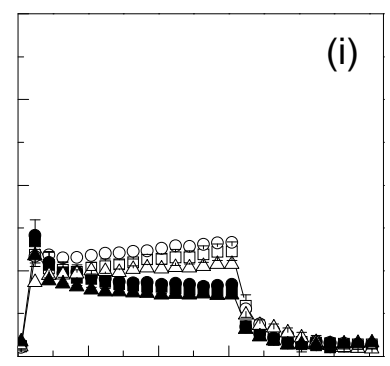

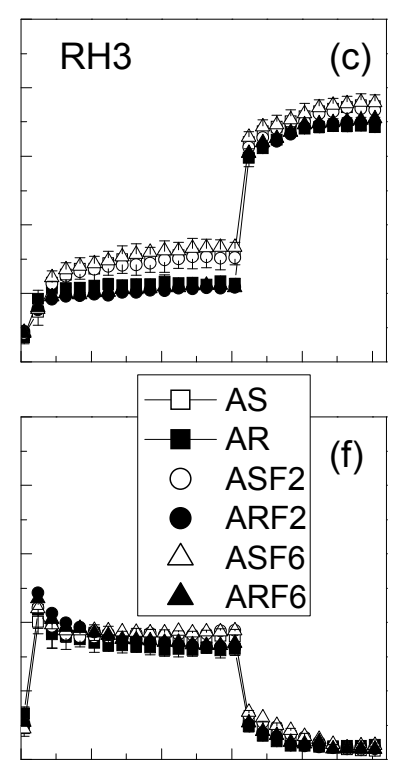

(i)

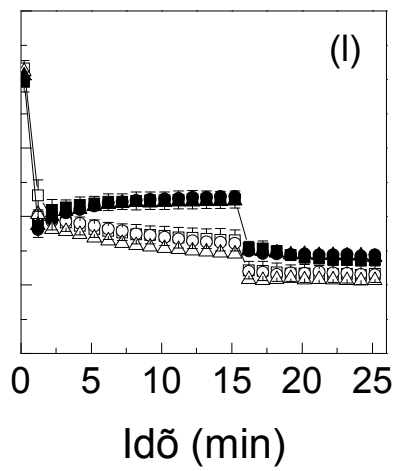

21. ábra Az erös szárazság (DH3) hatása a PSII komplementer hatásfokok és az NPQ indukció (1250 umol foton $\mathrm{m}^{-2} \mathrm{~s}^{-1}, 15$ perc) és sötétrelaxáció válasz görbéire AS (üres szimbólum) és AR (teli szimbólum) $S$. nigrum biotípusok leveleiben, és hibridjeikben. AS és AR, szülö, $-\square-e ́ s-$ -; ASF2 és ARF2, ○ és ; ASF6 és ARF6, $\triangle$ és $\mathbf{\Delta}$. a, b, c-fotokémiai energia konverzió $\Phi_{P S I}$, rendre kontroll, $D H 3, R H 3 ; d$, e, $f$-regulált energia disszipáció $\Phi_{N P Q}$, rendre kontroll, DH3, RH3; $g, h$, $i$ - nem fotokémia kioltás NPQ, rendre kontroll, DH3, RH3; $j, k, l-n e m-$ regulált energia disszipáció, rendre kontroll, DH3, RH3 $\Phi_{N O}$. Az adatok 12 ismétlés átlagai, a $S D$ a szülö (AS és AR) populációban van feltüntetve. 
A vízhiány hatására jelentős NPQ növekedéssel szembesültünk mindkét biotípusban és hibridjeikben is a kontrolljaikhoz képest, azonban az AR típusokban messzemenően nagyobb növekményt tapasztaltunk, mint AS párjaikban (21. h ábra). A sötétadaptált levél megvilágítása után a vad AS típusokban az NPQ lassan kezdett emelkedni, és kb. 8 perc alatt érte el az 1,7 értéket, majd ez közel változatlan maradt a megvilágítás végéig. Az AR biotípusban az NPQ jelentősen gyorsabban alakult ki, és kb. a negyedik percben elérte a 2,5 értéket, majd enyhe csökkenés után a megvilágítás végén ez kb. 2,2-re mérséklődött. A fény kikapcsolása után az NPQ nem relaxálódott teljesen egyik biotípusban sem, statisztikailag nem mutatható ki különbség a biotípusok között. A $\Phi_{\mathrm{NPQ}}$ görbék alakja (21. e ábra) szorosan tükrözte az NPQ görbék menetét (21. h ábra) a vízhiányos növényekben, ami a jó vízellátású növényi anyag estében nem mondható el. A kontrollokban és a vízhiány után rehidratált növényekben (21. j és 1 ábrák) a $\Phi_{\mathrm{NO}}$, vagyis a konstitutív energia veszteség szignifikánsan magasabb volt az AR vonalakban, azonban a vízmegvonás megfordította ezt a tendenciát. Az AR vonalakban kissé lecsökkent, míg az AS típusokban megemelkedett a $\Phi_{\mathrm{NO}}$, mely különbség a megvilágítás végére mérséklödött a kétféle biotípus között, de némiképpen megmaradt az AS típus magasabb értéke (21. k ábra). Míg a vízhiányos AR vonalakban az aktinikus fény kikapcsolása nem befolyásolta a $\Phi_{\mathrm{NO}}$ értékét, addig az AS vonalakban ez lecsökkent, hasonlóan a kontroll és a rehidratált növények esetében. 


\subsection{Egyes nukleáris öröklődésü faktorok hatása a fotoszintetikus fényenergia hasznosításra}

Csökkent NPQ kapacitással bíró $A$. thaliana mutánsokat széles körben alkalmaznak manapság az NPQ mechanizmusának tanulmányozásában. Az NPQ kialakulásának fontos tényezöi közé tartoznak a nukleárisan kódolt PsbS és az LHC proteinek. Npq vagy lhc mutáns $S$. nigrum növényeket ez idáig nem izoláltak; D1 protein mutáns $A$. thaliana vonalhoz nem sikerült hozzájutnunk, ezért két csökkent NPQ kapacitással bíró Arabidopsis vonalat tanulmányoztunk, melyek nukleáris mutációt hordoztak, hogy közelebb jussunk az anyai öröklődésủ D1 protein S264G mutáció és a csökkent NPQ folyamatok kapcsolatának megértéséhez a $S$. nigrum növényekben.

Az alkalmazott nevelési körülmények között a vad-típusú Col-0 és az npq4 mutáns növények közel azonos Chl $(a+b)$ tartalmakkal bírtak (11. táblázat), míg az lhcb2 vonal enyhén magasabb Chl $(a+b)$ tartalommal rendelkezett a vad típussal összehasonlítva. Mindkét mutáns vonalban megemelkedett a Chl $a / b$ arány a vad típushoz képest, azonban az $n p q 4$ mutánsban az emelkedés igen csekély volt.

11. táblázat Különbözö A. thaliana vonalak pigmentösszetétele

\begin{tabular}{lccc}
\hline \multirow{2}{*}{ Pigment } & \multicolumn{3}{c}{ Arabidopsis vonalak } \\
\cline { 2 - 4 } & Col-0 (vad típus) & lhcb2 & $n p q 4$ \\
\hline $\mathrm{Chl}(a+b)\left(\mu \mathrm{mol} \mathrm{m}^{-2}\right)$ & $129 \pm 4$ & $143 \pm 3$ & $128 \pm 3$ \\
$\mathrm{Chl} a / b$ & $2,57 \pm 0,1$ & $3,16 \pm 0,2^{\mathrm{c}}$ & $2,87 \pm 0,2$ \\
Karotinoidok $\left(\mu \mathrm{mol} \mathrm{m}^{-2}\right)$ & $41 \pm 4$ & $43 \pm 4$ & $46 \pm 5$ \\
Chl $(a+b) /$ Karotinoidok & $3,2 \pm 0,1$ & $3,5 \pm 0,4$ & $2,8 \pm 0,2$ \\
Vio+Ant+Zea $\left(\mu \mathrm{mol} \mathrm{m}^{-2}\right)$ & $12,3 \pm 1,6$ & $13,8 \pm 1,5$ & $12,5 \pm 1,1$ \\
$\left(\right.$ Vio+Ant+Zea) $/(\mathrm{Chl}(a+b))\left(\mu \mathrm{mol} \mathrm{mmol}^{-1}\right)$ & $93 \pm 6$ & $96 \pm 2$ & $98 \pm 4$ \\
DEi & $0,60 \pm 0,03$ & $0,54 \pm 0,04$ & $0,58 \pm 0,03$ \\
\hline
\end{tabular}

Az adatok három független kisérletböl 5 ismétlés átlagai $\pm S D$. A “c" szignifikáns eltérést jelöli a vad típus és a mutáns vonal között 5\%-os tévedési valószinüségi szinten. 
Nem találtunk szignifikáns eltéréseket a három Arabidopsis vonal között a karotinoid összetétel, a xantofill ciklus készlet méret, vagy a xantofill ciklus készlet méret és Chl tartalom aránya tekintetében, sem a xantofill ciklus pigmentek de-epoxidációs indexében (DEi). A 22. ábrán összehasonlítom a lineáris elektrontranszport sebesség ( $\left.\mathrm{J}_{\mathrm{ETR}}\right)(\mathrm{a})$, az NPQ kapacitás (b) és a PSII-re ható gerjesztési nyomás $(1-\mathrm{qP})(\mathrm{c})$ fényintezitás függéseit a három Arabidopsis vonalban. A $\mathrm{J}_{\mathrm{ETR}}$ és az NPQ értékei emelkedtek a növekvő fényintenzitással valamennyi $A$. thaliana vonalban, noha mindkét mutánsban az NPQ értékei alul maradtak a vad típusnak. Az lchb2 növényekben az NPQ kissé alacsonyabb értékről indult, mint az npq4 mutánsban, és ezek maximális értéke $\mathrm{kb}$. 50\%-kal volt kisebb, mint a vad típusé. A $\mathrm{J}_{\mathrm{ETR}}$ fényintenzitás függése közel azonos volt a vad és az lhcb2 vonalban, azonban az npq4 mutáns magas fényintenzitásokon kissé alacsonyabb értéket produkált. Az NPQ kapacitás és a PSII-re ható gerjesztési nyomás között, ahogy ez várható volt, fordított összefüggést kaptunk. Az npq4 mutánsokat magasabb $1-\mathrm{qP}$ érték jellemezte, így magasabb redukált $\mathrm{Q}_{\mathrm{A}}$ koncentráció, valamennyi fényintenzitáson, a vad típushoz képest (22. c ábra). Azonban az antiszensz lhcb2 növényekben ez kissé alacsonyabbnak bizonyult, mint a vad típsuban.
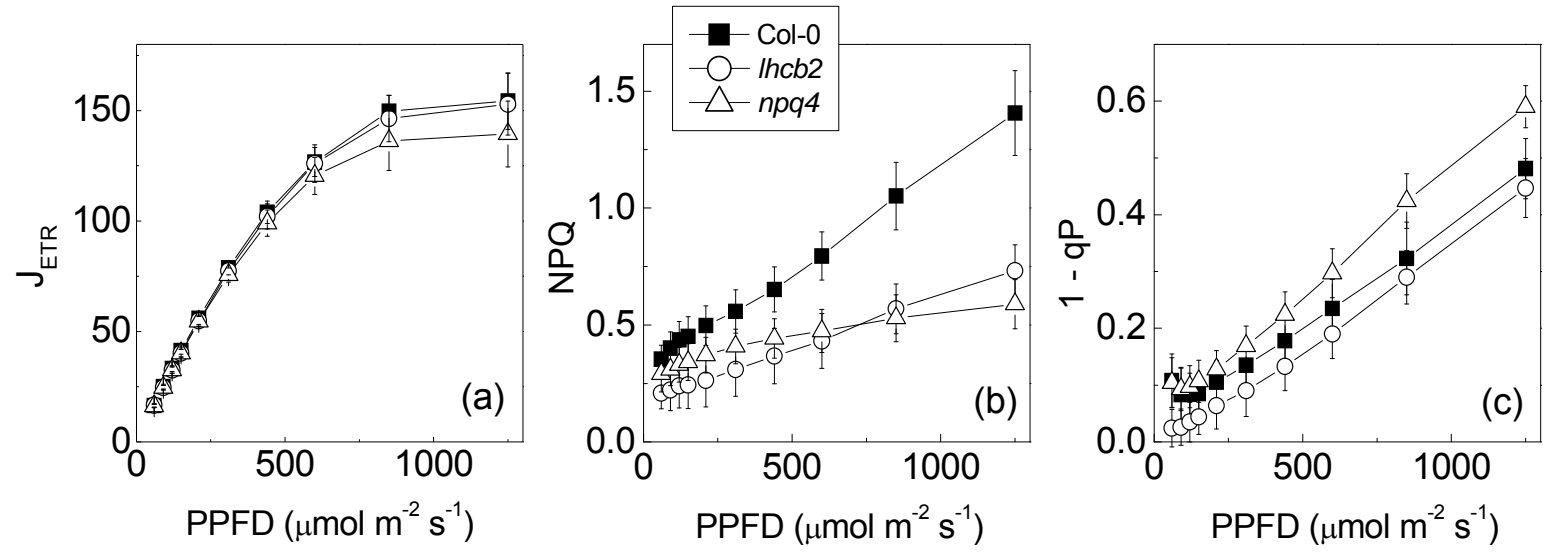

22. ábra A fotoszintetikus elektrontranszport sebesség ( $J_{E T R}$ a), a nem-fotokémiai kioltás $(N P Q, b)$ és a PSII-re ható gerjesztési nyomás $(1-q P, c)$ aktinikus fényre adott válaszgörbéi három Arabidopsis vonal leveleiben. Col-0, $\mathbf{\square}$; lhcb2, $\bigcirc$; npq4, $\triangle$. Az adatok három független kísérletböl 6 ismétlés átlagai $\pm S D$. 
Mind az $l h c b 2$, mind az $n p q 4$ növények szignifikánsan érzékenyebbek voltak a magas fényintenzitás által indukált fénygátlásra, mint a vad típus, melyet az $\mathrm{F}_{\mathrm{v}} / \mathrm{F}_{\mathrm{m}}$ paraméterrel jellemeztünk $(0,805 \pm 0,066 \rightarrow 0,138 \pm 0,044$ és $0,827 \pm 0,007 \rightarrow 0,112 \pm 0,053$ az lhcb2 és az $n p q 4$ vonalakban, a Col-0 vad típusban pedig $0,832 \pm 0,007 \rightarrow 0,353 \pm 0,062$, kontroll körülmények között mérve illetve magas fényintenzitással $\left(1400 \mu \mathrm{mol}\right.$ foton $\left.\mathrm{m}^{-2} \mathrm{~s}^{-1}\right) 4$ órán keresztüli megvilágítás után). A $\Phi_{\mathrm{PSII}}$ aktinikus fényre adott válasz görbéi alapján valamennyi Arabidopsis vonal közel aznonos PSII hatásfokkal bírt (23. a ábra). Az lhcb2 és az npq4 vonalakban a $\Phi_{\mathrm{NPQ}}$ alacsonyabb volt, mint a vad típusban (23. b ábra). Úgy tünik, hogy az alacsonyabb $\Phi_{\mathrm{NPQ}}$ értékek jól korrelálnak a csökkent NPQ kapacitással mindkét mutáns vonalban (22. b ábra). A $\Phi_{\mathrm{NPQ}}$ görbék alakja a két mutánsban hasonlóságot mutatott azok NPQ görbéinek alakjával (22. b és 23. b ábrák). A két mutáns vonalban a $\Phi_{\mathrm{NO}}$ értékei meghaladták a vad típusét valamennyi fényintenzitáson, melynek maximuma kb. 0,44 volt, míg a vad típusban csupán kb. 0,3. Ez a növekmény az alacsonyabb fotoprotektív kapacitás mintegy lehetséges kompenzációjaként szolgálhat (23. c ábra).
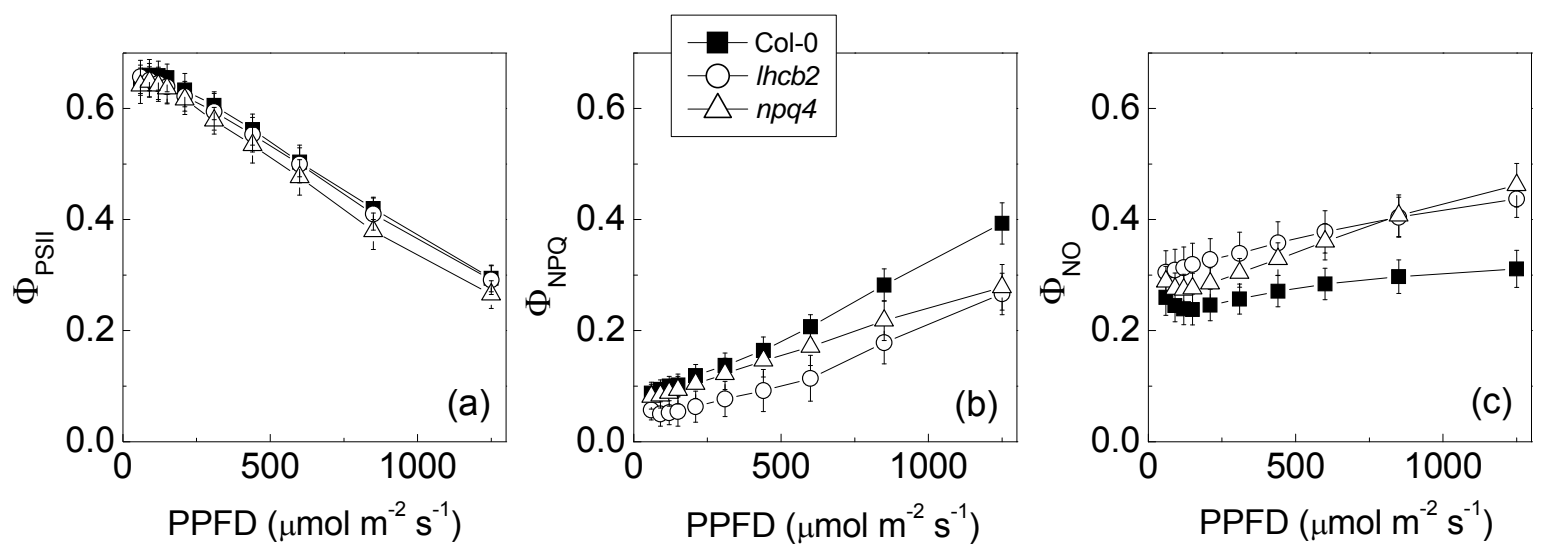

23. ábra A PSII komplementer hatásfokok aktinikus fényre adott válaszgörbéi. $\Phi_{P S I}$, fotokémiai energia konverzió (a); $\Phi_{N P Q}$, regulált energia disszipáció (b); $\Phi_{N O}$, nem-regulált energia disszipáció (c) három Arabidopsis vonal leveleiben. Col-0, ם; lhcb2, ○; npq4, $\triangle$. Az adatok három független kísérletböl 6 ismétlés átlagai $\pm S D$. 


\section{EREDMÉNYEK MEGVITATÁSA}

A PSII D1 RC fehérje valamennyi oxigénfejlesztő fotoszintézist folytató élő szervezetben megtalálható. Szerkezete erősen konzervált, mely azt engedi feltételezni, hogy a fehérje alapvető funkciója az evolúció során optimalizálódott. Valamennyi természetes módon kiszelektálódott AR gyomfaj PSII RC-a egy szerkezetileg módosult D1 fehérjét tartalmaz, mely a plasztokinon $\left(\mathrm{Q}_{\mathrm{B}}\right)$ kötőhelyhez közeli $\operatorname{Ser}_{264} \rightarrow$ Gly aminosav cserének tudható be (Gronwald, 1994; Tian \& Darmency, 2006; Trebst, 1991).

Erős napsugárzás következtében a növények az elnyelt többletenergiát nem képesek a fotoszintetikus elektrontranszporton keresztül hasznosítani. Ilyenkor a többlet gerjesztési energia termális disszipációja indukálódik, mely a PSII fotoprotekcióját hivatott biztosítani. Az NPQ a kloroplasztiszok tilakoid membránjában végbemenő folyamatok eredményeként alakul ki, többek között a tilakoid lumenének alacsony kémhatása, a PsbS és az LHC fehérjék protonációja, valamint a Zea képződése által. Az NPQ domináns, gyorsan relaxálódó frakcióját, mely a $\Delta \mathrm{pH}$-tól függ, energiafüggő kioltásnak nevezik (qE). Az ez idáig tanulmányozott D1 protein mutáns gyomfajokra a PSII müködésének csökkent hatékonysága jellemző: az alacsonyabb fényindukált fotokémiai kioltás (qP), mely fokozza a PSII-re ható gerjesztési nyomást $(1-\mathrm{qP})$, az alacsonyabb PSII hatásfok ( $\left.\Phi_{\mathrm{PSII}}\right)$, a lassabb elektrontranszport sebesség ( $\left.\mathrm{J}_{\mathrm{ETR}}\right)$ közvetlenül a D1 fehérje müködésével vannak kapcsolatban. Ezek a mutánsok csökkent nem-fotokémiai kioltási kapacitással (NPQ, qE) bírnak, melyet eddigi tudásunk alapján sejtmagban kódolt faktorok szabályoznak. A S. nigrum növényekben az atrazin rezisztenciát, egyetértésben korábbi munkákkal (Darkó et al., 1996; 2000; Váradi et al., 2003), az NPQ (qE) kapacitás jelentős csökkenése kíséri (3. táblázat és 8. ábra) (Bajkán et al., 2010). Néhány kétszikü gyomfaj AR biotípusaiban a $\mathrm{J}_{\mathrm{ETR}} 30 \%$-kal bizonyult alacsonyabbnak, mint AS párjaikban, mely az alacsonyabb PSII fotokémiai hatásfokot tükrözi, ezenkívül 20\%-kal kisebb Zea képződés és az NPQ (qE) kapacitásban 5070\%-os csökkenés volt tapasztalható (Váradi et al., 2003).

Módosult NPQ kapacitással rendelkező Arabidopsis mutánsokkal végzett kutatások során fény derült az alacsony NPQ néhány lehetséges okára, úgymint a PsbS fehérje hiánya vagy mutációja (Li et al., 2000; 2002b; Niyogi, 1999; Peterson \& Havir, 2001), az alacsony xantofill ciklus kapacitás és a Vio de-epoxidáz enzim hiánya vagy mutációja (Niyogi et al., 
1998; Peterson \& Havir, 2000), a $\Delta \mathrm{pH}$ kialakulásának gátlása (Goss et al., 2008; Pfündel et al., 1994), vagy az LHCII antiszensz inhibíciója (Andersson et al., 2001; Kovács et al., 2006). A szakirodalomban elfogadott tény, hogy az NPQ függ a tilakoid lumen alacsony kémhatásától, ami események sorozatát indítja be, melyben bennefoglaltatik a pigmentösszetétel megváltozása és a PSII antenna komplexek szerkezeti újrarendeződése.

A szakirodalom szerint az NPQ kialakulásában esszenciális faktorok sejtmagi gének által kódoltak (Funk et al., 1995; Li et al., 2000; Bugos \& Yamamoto, 1996; Jansson, 1999), habár a D1 fehérjét kódoló $p s b A$ gén a kloroplasztisz genom része. Nem világos, hogy a D1 fehérje milyen hatással van az antennában végbemenő hődisszipáció kialakulására. Ezért nem zárható ki az, hogy a S. nigrum és más gyomfajok (Darkó et al., 1996; 2000; Váradi et al., 1994; 2003) AS és AR biotípusai között tapasztalható különbség az NPQ (qE) kapacitásban a biotípusok genetikai hátterének eltéréséből adódik, semmint a D1 fehérje mutációnak köszönhető. Hogy ezt az eshetöséget feltárjuk, reciprok keresztezéseket végeztünk a S. nigrum kétféle szülő biotípusa között, és az ebből származó hibridekkel (F1, F2 egészen az F6-ig) vizsgálatokat folytattunk. Azt feltételeztük, hogy ha a vad AS és a D1 mutáns AR biotípusok különböznek egymástól az NPQ-val összefüggő nukleárisan kódolt tulajdonságokban, a reciprok keresztezések a utód-generációkban az NPQ tulajdonságokat változtatni fogják. Azonban azt találtuk, hogy az NPQ kapacitásbeli különbséget nem befolyásolták a sejtmagi szabályozó faktorok a hibridekben egészen az F6 generációig (8. ábra) (Bajkán et al., 2010). Ezt az a tény is támogatja, hogy a szekvencia analízis alapján a $S$. nigrum AS és AR biotípusaiban azonosak voltak a PsbS fehérjék, azaz nem tartalmaztak aminosav eltérést (11. ábra), és a PsbS és D1 fehérjék expressziójában sem találtunk különbségeket (12. ábra) (Bajkán et al., 2010).

A reciprok keresztezésekből való D1 protein mutáns $S$. nigrum vonalak (AR, ARF2, ARF6) az elnyelt energiát kevésbé hatékonyan hasznosították fotokémiára ( $\left.\Phi_{\mathrm{PSII}}\right)$, mint a vad biotípusok (AS, ASF2, ASF6) és a köztes elektron akceptorok felé irányuló elektrontranszport sebessége ( $\mathrm{J}_{\mathrm{ETR}}$ ) 30\%-kal bizonyult alacsonyabbnak közel telítési fényintenzitáson (5. a és b ábrák) (Bajkán et al., 2010). A D1 protein mutáció hátterének és lehetséges következményeinek jobb megértése végett két modellt használtunk, hogy meghatározzuk az elnyelt fényenergia megoszlását, mely egyrészt fotokémiailag hasznosulhat a PSII-ben $\left(\Phi_{\mathrm{PSII}}\right)$, másrészt disszipatív folyamatok eliminálhatják regulált és nem-regulált utakon keresztül. Az 
NPQ paraméter a hődisszipáció sebességével arányos, azonban nem nyújt kvantitatív információt arról, hogy mekkora energiafrakció disszipálódott el hőként a PSII antennarendszerében. Hendrickson és munkatársai (2004) modellje a fotoszintetikus energiaátvitel területén már korábban is létező, jól definiált hatásfokokon alapszik, úgymint a $\Phi_{\mathrm{PSII}}$ (Genty et al., 1989), $\Phi_{\mathrm{NPQ}}, \Phi_{\mathrm{NO}}$ (Cailly et al., 1996), illetve hatékonyan különíti el ez utolsó kettőt, a regulált és nem-regulált energia disszipációs folyamatokat; kiküszöböli az ún. többletenergia frakció problematikáját, nem úgy, mint Demmig-Adams és munkatársai (1996) modellje, mely abban különbözik az előzőtől, hogy az ő kalkulációjukban a többletenergia frakció $\left(\Phi_{\mathrm{E}}\right)$ is bennefoglaltatik, mely nem hasznosul a fotokémia folyamatában és termálisan sem disszipálódik el. A PSII energia allokációjának összehasonlító analízise Demmig-Adams és munkatársai (1996) modellje alapján azt mutatta, hogy a különböző gyomfajok AS és AR biotípusaiban a fotoszintetikus energia konverzió megváltozott szabályozása a D1 protein mutációval volt összefüggésben (Váradi et al., 2003). Ugyanakkor a fényadaptált AR növények alacsonyabb NPQ szintje és megnövekedett energia disszipációs kapacitása között ellentmondás tárult fel (Váradi et al., 2003). A PSII fotokémiára történő energia-felhasználás ( $\left.\Phi_{\text {PSII }}\right)$ az aktinikus fényre adott válaszgörbék alapján szignifikánsan alacsonyabb volt a $S$. nigrum AR vonalaiban (AR, ARF2, ARF6) mint a vad típusokban (AS, ASF2, ASF6), azonban a D1 fehérje mutáció nem volt hatással a fényben disszipált hőenergia frakciójára $\left(\Phi_{\mathrm{DL}}\right)$ vagy inkább kissé emelte azt, az alacsonyabb NPQ kapacitás ellenére (9. ábra). Ugyanakkor a többletenergia disszipációja $\left(\Phi_{\mathrm{E}}\right)$ szintén szignifikánsan magasabb volt a $S$. nigrum D1 mutáns vonalaiban (9. ábra). Az elnyelt többletenergia másfelöl reaktív oxigén formák képződéséhez vezethet az antennában és/vagy redukálhatja a molekuláris oxigént, mely potenciálisan károsíthatja a fotoszintetikus rendszert. Kato és munkatársai (2003) szerint a többletenergia frakció a PSII fotoinhibíciójának sebességi állandóját határozza meg a levelekben. Az AR vonalak alacsonyabb $\mathrm{Chl} a / b$ aránya AS párjaikhoz képest (4. táblázat) (Bajkán et al., 2010) jelezheti a fotoszintetikus apparátus egy relatíve nagyobb fénybegyüjtő antenna méretét (Burke et al., 1982; Holt \& Goffner, 1985; Lemoine et al., 1986), amely nagyobb mennyiségü többlet gerjesztési energia jelenlétéhez vezethet az antennában.

A Hendrickson és munkatársai (2004) által leírt modell a PSII antennájában elnyelt fényenergia sorsának az előbbinél egy egyszerübb becslését nyújta. A szignifikánsan alacsonyabb $\Phi_{\mathrm{PSII}}$ értékek az AR vonalakban jelzik, hogy az elnyelt fényenergiának kisebb 
hányada alakult át kémiailag kötött energiává a fotokémiai töltésszétválasztás során, mint az AS vonalakban (10. a ábra). Ez jól korrelál az alacsonyabb fotoszintetikus teljesítmény indexszel $\left(\mathrm{PI}_{\mathrm{abs}}\right)$, különösen a gerjesztési energia befogásának lecsökkent arányával az AR vonalakban (5. táblázat és 7. ábra). A PSII fotokémiájának lecsökkent hatásfoka ( $\left.\Phi_{\mathrm{PSII}}\right)$ vagy a $\Phi_{\mathrm{NPQ}}$ vagy a $\Phi_{\mathrm{NO}}$ vagy mindkét folyamat feltétlen növekedését eredményezi. A $\Phi_{\mathrm{NPQ}}$ és a $\Phi_{\mathrm{NO}}$ paraméterek azt az energia frakciót mérik, mely két, egymással versengő, nem-produktív folyamat által disszipálódhat: míg a $\Phi_{\mathrm{NPQ}}$ a szabályozási folyamatok által indukálódik, ezzel szemben minden egyéb nem-fotokémiai energia-veszteséget a $\Phi_{\mathrm{NO}}$ képvisel. A $S$. nigrum szülö biotípusai és hibridjei között nem találtunk különbséget a $\Phi_{\mathrm{NPQ}}$ értékeiben (10. c ábra), viszont a qE lecsökkent a $\Phi_{\mathrm{NO}}$ növekedése mellett az AR vonalakban (3. táblázat és 10. e ábra). Mind a $\Phi_{\mathrm{NPQ}}$ mind a $\Phi_{\mathrm{DL}}$ a $\Delta \mathrm{pH}$-, Zea- és PsbS által szabályozott fotoprotektív NPQ mechanizmussal vannak kapcsolatban. A PSII akceptor oldali kisebb sebességü elektrontranszport $\left(\mathrm{J}_{\mathrm{ETR}}\right)$ ar AR vonalakban (10. b ábra) korlátozhatja a lumenális proton akkumulációt. Továbbá a D1 protein fény által indukált magasabb degradációs/helyreállítási folyamata az AR gyomokban (Sundby et al., 1993a; Darkó et al., 2000) maga után vonhat egy megnövekedett ATP igényt, ami az ATPáz enzimen keresztül magasabb proton effluxot eredményezhet, mely szintén hozzájárulhat a tilakoid membránon keresztüli proton gradiens kiépülésének csökkenéséhez. Ez magyarázatot adhat a 20\%-kal alacsonyabb xantofill deepoxidációra, amely pedig hozzájárulhat a qE csökkenéséhez. Tehát nem zárható ki, hogy a $\mathrm{Q}_{\mathrm{A}}$ és a $\mathrm{Q}_{\mathrm{B}}$ közötti elektrontranszport lassulása a D1 protein mutáns növényekben (Pfister \& Arnzten, 1979; Bowes et al., 1980) a lumen mérsékelt acidifikációját okozza, azonban a szakirodalomban általánosan elfogadott tény az, hogy a teljes fotoszintetikus elektrontranszport sebesség-limitáló lépése normál fiziológiás körülmények között a Cyt $b_{\sigma} / f$ komplex általi PQ készlet oxidációja (Genty \& Harbinson, 1996). A $\mathrm{CO}_{2}$ asszimiláció (3. táblázat) (Bajkán et al., 2010) és a fotorespiráció sebességei (3. táblázat és 15. c ábra) sem változtak a mutáció hatására, ami azt mutathatja, hogy a $\mathrm{Q}_{\mathrm{A}}$ és $\mathrm{Q}_{\mathrm{B}}$ közötti elektrontranszport lassulása ellenére sem a PSII limitálja a teljes elektrontranszportlánc sebességét az AR növényekben. Haehnel (1984) és Graber (1987) kutatásai alapján a rezisztens növényekben a $\mathrm{Q}_{\mathrm{A}}$ és $\mathrm{Q}_{\mathrm{B}}$ közötti elektrontranszport sebesség 0,3-0,4 ms körüli értékének lelassulása 1-3 ms-ra még mindig kb. tízszer gyorsabb mint a PQ készlet oxidációjának 15-25 ms-os félideje. 
Érdekes módon a qE lecsökkenését nem kíséri a $\Phi_{\mathrm{NPQ}}$ változása. Mivel a $\Phi_{\mathrm{NPQ}}-\mathrm{t}$ nem érintette a D1 protein mutációja, az egyéb nem-fotokémiai energia veszteségek hatásfoka, a $\Phi_{\mathrm{NO}}$, megemelkedett, mely a csökkent fotokémiai energia konverzió kompenzációs mechanizmusának tekinthető az AR vonalakban (10. e ábra). A $\Phi_{\mathrm{NO}}$ értelmezésére számos, részben különböző magyarázat létezik (Klughammer \& Schreiber, 2008), de általában úgy definiálják, hogy az elnyelt fényenergiának az a frakciója, amely nem hasznosul a fotoszintetikus elektrontranszport során, és nem is eliminálódik a regulált hődisszipáció folyamatán keresztül, hanem passzív módon hő és fluoreszcencia formájában disszipálódik. A magasabb $\Phi_{\mathrm{E}}$ vagy $\Phi_{\mathrm{NO}}$ értékek és az alacsonyabb $\Phi_{\mathrm{NPQ}} / \Phi_{\mathrm{NO}}$ arány a D1 protein mutáns vonalakban a fotoprotektív folyamatok szuboptimális kapacitását tükrözik (Klughammer \& Schreiber, 2008), mely végső soron a fotokémiai apparátus károsodásához vezet, mivel a $\Phi_{\mathrm{E}}$ és a $\Phi_{\mathrm{NO}}$ frakció nagyobb hányada azt az elnyelt energiát képviseli, melyet nem lehet a regulált mechanizmusok által a PSII antennarendszeréböl eltávolítani. Következésképpen a természetes módon kiszelektálódott D1 mutáns gyomok magasabb érzékenysége a fotoinhibícióra (Holt et al., 1981; Hart \& Stemler, 1990; Sundby et al., 1993a; Darkó et al., 1996; 2000; Váradi et al., 1994; 2003) nem meglepö, ha figyelembe vesszük, hogy a fotoinhibíció fő célpontja a PSII RC-ok D1 fehérjéje (Barber \& Andersson, 1992; Aro et al., 1993).

Összehasonlító tanulmányt végeztünk két, csökkent NPQ kapacitással rendelkező $A$. thaliana mutáns vonallal abban bízva, hogy közelebb jutunk a $S$. nigrum D1 protein mutáns biotípusának eltérő energia megoszlásának magyarázatához. Mivel megváltozott NPQ tulajdonsággal rendelkező mutáns vonalat a $S$. nigrum növényfaj esetében tudomásunk szerint ez idáig nem izoláltak, és a D1 protein mutáns $A$. thaliana vonalhoz nem jutottunk hozzá, ezért az A. thaliana npq4-1 deléciós mutánsával és az lhcb2 antiszensz vonallal végeztünk vizsgálatokat. Míg előzöben a $p s b S$ gén deléciója következtében a PsbS fehérje teljesen hiányzik, utóbbiban az LHCII fö alkotóelemei, az Lhcb1 és 2 fehérjék csaknem teljesen hiányoznak az Lhcb2 antiszensz konstrukció kifejeződése miatt. Mindkét vonal az irodalomban jól ismert és jellemzett (Li et al., 2000; 2002b; Ganeteg et al., 2001; Andersson et al., 2003; Ruban et al., 2003). Ezekben a növényekben kb. 50\%-os csökkenést tapasztaltunk az NPQ értékeiben közel telítési fényintenzitáson a vad típushoz képest (22. b ábra), miközben a $J_{\mathrm{ETR}}$ és a $\Phi_{\mathrm{PSII}}$ paraméterek értékei közel azonosak voltak mindhárom vonalban (22. a és 23. 
a ábrák). A Hendrickson és munkatársai (2004) modelljének alkalmazása azt mutatta, hogy az aktinikus fényre adott válaszgörbék esetében az alacsonyabb NPQ kapacitás, sőt magának a görbének az alakja is egyértelmüen tükröződik a $\Phi_{\mathrm{NPQ}}$ görbék alacsonyabb amplitudójában és felfutásában mindkét mutáns vonalban (22. b és 23. b ábrák) (Bajkán et al., 2011, közlésre elfogadva). Az alacsonyabb $\Phi_{\mathrm{NPQ}}$ értékekkel párhuzamosan a $\Phi_{\mathrm{NO}}$ megemelkedését tapasztaltuk (23. c ábra). Az $n p q 4-1$ és az lhcb2 A. thaliana mutánsok alacsonyabb fotoprotektív kapacitása következetesen tükröződött tehát az alacsonyabb $\Phi_{\mathrm{NPQ}}$ értékekben, azonban érdekes módon a $S$. nigrum D1 protein mutáns biotípusában a kisebb NPQ kapacitás mellett azonos $\Phi_{\mathrm{NPQ}}$-t tapasztaltunk a vad és a mutáns biotípusokban. Habár a PsbS és az LHC proteinek nukleárisan kódoltak, a D1 protein a kloroplasztisz genom része. Úgy gondoljuk, hogy a különféle megváltozott NPQ tulajdonsággal rendelkező mutánsokon végzett biokémiai és molekuláris genetikai tanulmányok közvetlenül nem illeszthetők rá a D1 protein mutáns biotípusú növények esetére a tanulmányozott mutációk alapvető különbségei miatt. Az $A$. thaliana növények magas és alacsony NPQ kapacitással rendelkező természetes változataival végzett újkeletü kutatások arra utalnak, hogy az NPQ kapacitásban meglévő különbségek néhány, eddig még nem ismert faktor szabályozása alatt állhatnak (Jung \& Niyogi, 2009).

A D1 fehérje mutáció következményeként a gyors Chl fluoreszcencia tranziensek alakja különbözött a kétféle biotípusban és a megfelelő hibridjeikben (6. ábra). Hasonló különbségeket az OJIP tranziensek alakjában korábban is leírtak Chlamydomonas D1 protein mutánsaira és néhány gyom esetében (El-Lithy et al., 2005; Kohno et al., 2000; Srivastava et al., 1995; van Rensen et al., 2001). Az OJIP tranziensek kinetikáját a $\mathrm{Q}_{\mathrm{A}}$ redox állapotának változásai határozzák meg, de egyúttal a fotoszintetikus elektrontranszportlánc redukcióját is tükrözi. A tranziensek J és I szintjei és I-P fázisa a $Q_{A}$ redox állapotával, a PQ készlet redox állapotával és a PSI elektron akceptor oldalán lévő végső akceptorok redox állapotával függenek össze (Tsimilli-Michael \& Strasser, 2008). Jóllehet az így kapott eredmények nem nyújtanak információt egy állandósult körülményre jellemző fotoszintetikus aktivitásról, csupán betekintést engednek egy sötétadaptált minta optimális-maximális hatékonyságába. A sötétadaptált leveleken mért gyors Chl fluoreszcencia tranziensek analízise egyértelmüen jelezte a PSII müködésének gyengülését az akceptor oldalon (úgymint az excitonok RC-ok általi befogásának hatásfoka, a $\mathrm{Q}_{\mathrm{A}}$ redukált formájának gyors felhalmozódása, ekképpen a PSII RC-ok gyors záródása, az elektrontranszport hatásfoka, az elektrontranszfer fluxusa per 
RC) az AR vonalakban, összehasonlítva AS párjaikkal (5. táblázat). Eszerint az AS és az AR biotípusok közötti fö különbség a PSII köztes elektron akceptor készlet feltöltésének kinetikájában van, ahogyan ezt van Rensen és munkatársai (2001) is fejtegették. A PI ${ }_{a b s}$ fotoszintetikus teljesítmény indexben a PSII komplex mind strukturális, mind müködési jellemzése bennefoglaltatik. A D1 fehérje mutáció csakugyan csökkentette a PSII müködésének intenzitását, amely jól látszik a $\mathrm{PI}_{\mathrm{abs}} 50 \%$-os esésében, ami valószínüleg okozhatja az alacsonyabb NPQ kialakulását, ahogyan ezt már korábban mások is feltételezték (Darkó et al., 2000; Váradi et al., 2003). Azonban a $\Phi_{\mathrm{NPQ}}$ és a $\mathrm{CO}_{2}$ asszimiláció fénytelítési sebességeinek hasonló értékeire a $S$. nigrum AS és AR vonalaiban ez nem ad magyarázatot (3. táblázat) (Váradi et al., 2003; Bajkán et al., 2010).

A PSI végső akceptorainak redukcióját jellemző gyors Chl fluoreszcencia paraméterek $\left(\mathrm{RE}_{\mathrm{o}} / \mathrm{RC}, \varphi_{\mathrm{Ro}}, \psi_{\mathrm{Ro}}\right)$ nem különböztek szignifikánsan a kétféle biotípusban és azok hibridjeiben. A $\delta_{\text {Ro }}$ paraméter azonban, mely annak a valószínúségét fejezi ki, amellyel egy elektron a köztes elektron akceptorok felöl a PSI végső akceptorokhoz eljut, az AR biotípusokban jelentősen megnövekedett (5. táblázat és 7. ábra). A megemelkedett $\delta_{\text {Ro }}$ paraméter a $V_{J}$ növekedéséböl adódott, míg a $\mathrm{V}_{\mathrm{I}}$ nem különbözött szignifikánsan a biotípusokban. A JIP-teszt analízis során a D1 protein mutáns vonalakban magasabbnak bizonyul az az arányszám $\left(\delta_{\mathrm{Ro}} /\left(1-\delta_{\mathrm{Ro}}\right)\right)$, mely azt jellemzi, hogy egy elektron a redukált köztes akceptorok felöl a PSI végső akceptorokhoz jut. Ez feltételezhetően kompenzálhatja a PSII akceptor oldali alacsonyabb elektronáram-sebességet és a $\mathrm{PI}_{\mathrm{abs}}$-t, és hasonló $\mathrm{PI}_{\text {total }}$ értékeket eredményez a $S$. nigrum biotípusaiban (5. táblázat). A hasonló $\mathrm{PI}_{\text {total }}$ értékek valószínűsítik a redukáló erők összehasonlítható mennyiségének kialakulását a PSI akceptor oldalán mindkét biotípusban. A PSI körüli ciklikus elektrontranszportról néhányan azt tartják, hogy jelentős elektronáramot képes fenntartani és ezáltal hozzájárul a lumen acidifikációjához (Miyake et al., 2004; Munekage et al., 2004). Termolumineszcencia (TL) vizsgálatok a Chenopodium album AR biotípusában kimutatták az AG sáv meglétét, mely azokból a PSII centrumokból származik, melyekben az oxidált $\mathrm{Q}_{\mathrm{B}-\mathrm{t}} \mathrm{a}$ PQ készlet felőli, sztróma reduktánsokból származó, reverz irányú elektrontranszport redukálja (Sundblad et al., 1988). Ennek a TL sávnak a kialakulásához ciklikus elektrontranszport és magas lumen protonkoncentráció szükséges (Ducruet et al., 2005). A RE $/ \mathrm{RC}, \varphi_{\mathrm{Ro}}, \psi_{\mathrm{Ro}} \mathrm{JIP}-$ teszt paraméterek hasonlósága a biotípusokban és különösképpen a megnövekedett $\delta_{\mathrm{Ro}} \mathrm{az} \mathrm{AR}$ vonalakban valamennyien a PSI végső akceptorainak (Fd, NADP) redukcióját tükrözik, ami az 
AG sáv jelenlétével együtt egy aktív PSI körüli ciklikus elektrontranszportra és hozzákötött protontranszferre utal.

Összegzésként elmondható, hogy a $p s b A$ gén által kódolt, erősen konzervált D1 protein szerepét az elnyelt többletenergia termális disszipációjának hatékony kialakulásában esszenciálisnak véljük, miként ezt a kloroplasztisz genomban kódolt S264G D1 mutáció és az alacsony NPQ kapacitás együtt-öröklődése igazolta. Az eredményeink azt mutatják, hogy az általunk vizsgált Chl fluoreszcencia tulajdonságokat, úgymint az OJIP tranzienseket és a JIP teszt paramétereket, az NPQ-t és a PSII antennája által elnyelt energia allokációs mintázatot a D1 protein befolyásolja az AS és az AR biotípusú $S$. nigrum növények leveleiben.

A szárazság napjainkban igen fontos környezeti tényezővé vált, mely a növekedés gátlását eredményezi a fotoszintézis folyamatának limitálása révén. Természetes körülmények között a vízdeficit gyakran együtt jár a magas hőmérséklettel és/vagy a magas fényintenzitással (fénygátlás). Ismeretes, hogy a magas fényintenzitással (Sundby et al., 1993a; Váradi et al., 1994; Darkó et al., 1996; 2000) és hőmérséklettel (Ducruet \& Lemoine, 1985, Havaux, 1989) szemben az AR gyomoknak kisebb a toleranciájuk, mint a vad-típusú párjaiknak. Kíváncsiak voltunk arra, hogy a szárazság, mint abiotikus faktor, hogyan befolyásolja az atrazin rezisztenciát hordozó S. nigrum növényekben az elnyelt fényenergia sorsát a vad biotípussal összehasonlítva; a vízdeficit befolyásolja-e a mutáns növények fitneszét.

A jó vízellátású kontroll AS és $\mathrm{AR} S$. nigrum szülö biotípusokban a sztómák vezetőképessége $\left(\mathrm{g}_{\mathrm{s}}\right)$ közel azonosnak bizonyult, melyet az AR biotípusra jellemző alacsonyabb sztómasürüség nem befolyásolt (14. a ábra). Korábbi kutatások nem találtak különbséget az AS és az AR biotípusok között a sztómasürüséget illetően és a sztómák müködésében (Ort et al., 1983; Holt \& Goffner, 1985). A $\mathrm{CO}_{2}$ asszimiláció aktinikus fényre adott válaszgörbéi szintén hasonlóak voltak a kétféle kontroll biotípus leveleiben (15. a ábra) egyetértésben korábbi munkákkal (Váradi et al., 2003), habár PSII-n keresztüli lineáris elektrontranszport sebessége ( $\left.\mathrm{J}_{\mathrm{ETR}}\right)$ szignifikánsan alacsonyabbnak bizonyult az AR biotípusban (5. b ábra, $\mathrm{J}_{\mathrm{ETR}}$ ). Enyhe szárazság alatt a sztómazáródás az első lépés, amelyet szükségszerüen a fotoszintetikus reakciók megváltozása követ (Cornic \& Briantais, 1991). Vízhiány esetén a levelek asszimilációs rátája visszaesik, sőt mi több ez már akkor is tapasztalható, mielőtt a levelek vízállapotában változások játszódnának le, amikor a levegő 
páratartalmának (Bunce, 1981) vagy a talaj vízpotenciáljának csökkenése bekövetkezik (Gollan et al., 1986). Valóban, az öntözés megvonása után először a g $\mathrm{g}_{\mathrm{s}}$ esett vissza, melyet röviddel ezután, néhány nap múlva, a RWC és a levelek átlagos vízpotenciáljának ( $\Psi)$ csökkenése is követett mindkét biotípusban (14. ábra és 8. táblázat). Szembetünő volt, hogy az AR biotípusban a szárazság által indukált csökkenés a vízháztartási paraméterekben később ment végbe, mint a vad típusban. A kétféle biotípus között a legnagyobb különbség föképpen az enyhe szárazság szakaszára (DH1) tehető, majd ez a különbség az idő előrehaladtával mérséklődött és meg is szünt a DH2 szakaszban (14. ábra). Az AR biotípus levélszöveteinek magasabb átlagos vízpotenciálja progresszív vízhiány alatt együtt járt a gázcserenyílások nagyobb mértékű nyitottságával és a magasabb g értékekkel.

Enyhe vízhiány mellett (DH1) a $\mathrm{CO}_{2}$ asszimiláció intenzitásának csökkenése valóban a sztómák vezetőképességének csökkenésével mutatott inkább összefüggést, mint a levél vízháztartási paramétereivel (RWC, $\Psi)$ (15. ábra). Kimutatták, hogy a száraz periódus fokozhatja a fotorespiráció mértékét (Cornic \& Fresneau, 2002), ami szárazság idején hozzájárulhat a fotoszintetikus apparátus védelméhez a fény általi károsodással szemben (Chaves et al., 2003). A fotorespiráció (az 1\% és 21\% $\mathrm{O}_{2}$ tartalmú levegöben meghatározott asszimilációs ráták különbsége) mértékének emelkedését tapasztaltuk vízdeficit alatt a $S$. nigrum mindkét biotípusában (15. d-i ábrák). A fotorespiráció mértéke, vagyis a fotorespirációs szén veszteség az AR biotípusban alacsonyabbnak bizonyult, mint az AS párjában, ami jól korrelál a sztómák nagyobb vezetőképességével, mely lehetővé teszi a $\mathrm{CO}_{2}$ jobb hozzáférhetőségét a Rubisco enzim számára a kloroplasztiszok sztrómájában. Ezalatt az AS biotípusban a nagyobb mértékü sztómazáródás a $\mathrm{CO}_{2}$ kisebb elérhetőségét vonta maga után $\left(\mathrm{C}_{\mathrm{i}}\right.$ csökkenése), melynek következtében a Rubisco enzim oxigenációs aktivitása megnövekedhetett a karboxiláció rovására.

A vízhiány alatt - a legtöbb esetben - a tilakoid membrán szerkezete ép maradt mindkét biotípusban (Függelék 1. ábra). A rehidrációt követően a helyreállási folyamatok végbementek, melynek köszönhetően 30 perccel a rehidráció után azt tapasztaltuk, hogy a $\mathrm{CO}_{2}$ asszimiláció megindult és egy gyors emelkedés után egy lassabb fázis következett (adatok nincsenek bemutatva). 24 óra elteltével a rehidráció után a helyreállási folyamatoknak köszönhetően a kloroplasztiszok a sejtfal mellett szorosan helyezkedtek el (Függelék 1. ábra). 
A jó vízellátású kontroll biotípusok $\mathrm{A} / \mathrm{C}_{\mathrm{i}}$ görbéi gyakorlatilag nem különböztek a kétféle biotípusban, és a Rubisco aktivitása és/vagy extrahálható mennyisége ( $\varepsilon$ ) és a RuBP regenerációjának maximális sebessége $\left(\mathrm{J}_{\max }\right)$ szintén nagyon hasonlóak voltak (16. a ábra és 9 . táblázat). Néhányan úgy gondolják, hogy a Rubisco csökkent aktivitása és/vagy mennyisége (Castrillo et al., 2001; Parry et al., 2002; Tezara et al., 2002) vagy a RuBP regenerációjának elégtelen kapacitása (Tezara et al., 1999; Thimmanaik et al., 2002) a fotoszintézis limitáló faktorai lehetnek föként vízdeficit esetén (Bota et al., 2004). A vízmegvonás által indukált $\mathrm{CO}_{2}$ asszimiláció és az $\varepsilon$ csökkenése az AR biotípusban szignifikánsan alacsonyabb mértékü volt, mint az AS párjában (16. b és c ábrák). Az $\varepsilon$ paraméterről azt tartják, hogy a karboxilációs hatásfokot tükrözi, és általában a Rubisco enzim aktivitásával van összefüggésben (von Caemmerer, 2000). A növények rehidrációját követően 24 óra elteltével az $\mathrm{A} / \mathrm{C}_{\mathrm{i}}$ görbék amplitudója emelkedésnek indult (RuBP regenerációja), azonban a görbe kezdeti meredekségéből számolt Rubisco aktivitás közel változatlan maradt (16. ábra).

A S. nigrum AS és AR szülő biotípusok reciprok keresztezéseiből származó szárazságnak kitett F2 hibridek gázcsere vizsgálatai azt mutatták, hogy a szülő populációban meglévő különbség megszünt az F2 hibridek esetében (ASF2 és ARF2) (9. táblázat és 18. ábra), és a kétféle biotípus (ASF2 és ARF2) a szülő AR típus értékeit közelítette a vízhiány alatt. Elképzelhető, hogy a szülő AR biotípus horgas, kampós alakú levélszőrei, melyek a levél felületére kissé ráhajoltan helyezkedtek el (Függelék 2. ábra), hozzájárult a nagyobb vízmegtartó képesség kialakulásához. A fotoszintetikus teljesítmény mérsékeltebb visszaesése mellett, a nagyobb sztómanyitottság és a kedvezőbb levél vízpotenciál értékek együttes mutatkozása felveti az ozmotikumok nagyobb felhalmozódásának lehetőségét az AR növényekben, amely mérsékelheti az RWC-ben amúgy megmutatkozó vízvesztés káros élettani hatásait. Az AR biotípusra jellemző kampós levélszőrök is szerepet játszhatnak, növelve a levélfelületi diffúziós határréteg vastagságát, míg az AS típus egyenes szörei a levél felszínére közel merölegesek voltak, ezáltal kisebb hatást kifejtve. Rendszerint a sztómák válaszreakciói szorosabb összefüggést mutatnak a talaj nedvességtartalmának, mint a levél vízállapotának megváltozásával. Ezek alapján feltételezik, hogy a sztómák reagálnak a dehidratált gyökerek produktumaira (pl. az abszcizinsav), mint kémiai jelmolekulákra (Davies \& Zang, 1991). Ismeretes, hogy néhány növényfajban a szárazság hatására kifejezettebb abszcizinsav-függő sztómazáródás megy végbe (Riera et al., 2005). Elképzelhetö, hogy a $S$. 
nigrum AR biotípusában kisebb mértékü lehet az abszcizinsav által mediált sztómazáródás a vélhetően fokozottabb vízmegtartó képesség miatt, mint az AS típusban. A szárazság elleni egyik védekező mechanizmus a növényekben a rendelkezésre álló víz konzerválása, mely pl. a sztómaszám lecsökkentésével valósulhat meg (Schulze, 1986), ez azonban az itt alkalmazott kísérleti elrendezésben nem játszhatott szerepet.

Az eredményekböl azt a következtetést vonhatjuk le, hogy a S. nigrum AR biotípusának vízhiánnyal szembeni fokozottabb toleranciája nem köthető az S264G D1 protein mutációjához, mivel a reciprok keresztezésekből származó, a szülő populációkban meglévő különbségek az F2 hibridekben elmosódtak. Úgy feltételezzük, hogy az általunk tapasztalt különbség a szülő populációknak az élöhelyhez való alkalmazkodása során a sejtmagi genetikai háttér módosulásával alakulhatott ki, vagy a számos pleiotrop hatás egyike, amely a szelektálódott populációban az önbeporzás következtében fennmaradhatott. Megállapíthatjuk, hogy az atrazin-rezisztens biotípus rosszabb fitnesze nem magyarázható a vízhiánnyal szembeni tolerancia-csökkenésével.

A fotokémiai energia konverzió $\left(\Phi_{\mathrm{PSII}}\right)$ és a $\mathrm{J}_{\mathrm{ETR}}$ értékei igen jelentősen, közel azonos értékre estek vissza mindkét biotípusban és hibridjeikben is az erős vízdeficit (DH3) következményeként a kontroll növényekéhez képest (20. a, b és 10. a, b). Az AR vonalakban drasztikus emelkedést tapasztaltunk az NPQ paraméter értékében a jó vízellátású kontrollokhoz képest, mialatt az AS vonalakban jóval kisebb mértékü volt ez az emelkedés (19. a és 21. h ábrák). Érdekes módon mind a fényintenzitás-függés, mind a kinetikai vizsgálatok során az NPQ görbék amplitudója és felfutása tükrözte a $\Phi_{\mathrm{NPQ}}$ görbékéét a vízhiányos növényekben (19. a, 20. c, 21. e és h ábrák), nem úgy, mint a kontrollok esetében (21. $\mathrm{g}, \mathrm{d}, \mathrm{h}$ és e ábrák). Szárazság alatt a regulált termális disszipáció fokozódása a fénybegyüjtő komplexekben valamiképpen magában foglalja a xantofill ciklust (DemmigAdams \& Adams, 1996) és a lutein ciklust (Matsubara et al., 2001), jóllehet utóbbinak szerepe nem teljesen világos még. Amikor a $\mathrm{CO}_{2}$ fixációja gátolt a szárazság alatt, a szabályozó folyamatok révén visszaesik az elektrontranszport sebessége, ezáltal egyensúlyt teremtve az elektronok lecsökkent szükségletével és minimálisra csökkentve a reaktív oxigén formák keletkezését. Ugyanakkor az NPQ megnövekszik, hogy mérsékelje a PSII-n lévő gerjesztési nyomást. Golding és Johnson (2003) vizsgálataik során azt a megfigyelést tették, hogy az ‘aktív' PSI centrumok aránya megemelkedett a száraz periódus alatt. Feltételezéseik szerint 
ezek elsődlegesen a ciklikus elektrontranszportban vesznek részt, amely a $\Delta \mathrm{pH}$ fokozásával hozzájárul az NPQ fenntartásához, és megvédi a PSII-t. Viszont, amennyiben feltesszük, hogy a fokozott PSI aktivitás segít kiigazítani a lassúbb lineáris elektrontranszport okozta $\Delta \mathrm{pH}$ elmaradást, fel kell tételeznünk, hogy a de-epoxidációban, NPQ és qE folyamatokban meglévő tagadhatatlan hiányt más, akár az S264G mutáció pleiotrop hatása, mint pl. a lipidösszetétel és a membrán fluiditás jelentős megváltozásai is okozhatják. Érdekes módon, míg a kontoll AR vonalakban az alacsonyabb NPQ kapacitás mellett közel azonos $\Phi_{\mathrm{NPQ}}$ és szignifikánsan magasabb $\Phi_{\mathrm{NO}}$ értékeket kaptunk, addig az erős szárazságnak kitett AR növények leveleiben a drasztikusan lecsökkent fotokémiai hatásfok mellett erőteljesen megnőtt a regulált energia disszipáció frakciója, mely tükrözte a megnövekedett NPQ-t és kissé csökkent a nem-regulált utak általi energia disszipáció hatásfoka a kontrollokhoz képest. Ezzel szemben a vízhiányos AS vonalak NPQ kapacitása csak kis mértékben emelkedett a kontrollokhoz képest, amely a $\Phi_{\mathrm{NPQ}}$-ban is tükröződött, míg a $\Phi_{\mathrm{NO}}$ enyhén megnött a kontrollokhoz képest. Úgy tünik tehát, hogy az AR vonalakban (AR, ARF2, ARF6) az erős szárazság által indukált fotoprotekciós folyamatok hatékonyabban müködhetnek, mint az AS párjaikban (AS, ASF2, ASF6). Azonban ennek magyarázatához további vizsgálatokra lenne szükségünk. Az erős szárazságnak kitett szülő populációk és megfelelő hibridjeik a vizsgált fluoreszcencia tulajdonságokban nem különböztek egymástól, tehát e folyamatok a D1 protein mutációhoz köthetők. A vízhiányos mintában (DH3) a rehidratálás után a plasztiszszerkezet helyreállását tapasztaltuk (Függelék 1. ábra), illetve a kontrollokhoz hasonló NPQ kinetika és energia allokációs mintázat is visszaállt mindkét biotípusban (21. i ábra). 


\section{7. ÖSSZEFOGLALÁS}

Az oxigénfejlesztő fotoszintézis során a PSII molekuláris szerkezetének és müködésének két egymással ellentétes követelményt kell kielégítenie. Egyrészt a napsugarak hatékony begyűjtése szükséges a fotoszintetikus eletrontranszportlánc meghajtásához és annak optimális sebességének fenntartásához. Másrészt a klorofill gerjesztett állapota és a molekuláris oxigén jelenléte egy potenciálisan letális környezetet teremt, amely a fehérjéket, lipideket és a fotoszintetikus membrán pigmentjeit irreverzibilisen károsíthatja. Ennek kivédésére a fotokémiai rendszer egyes kofaktorai, úgymint a karotinoidok, amelyek a szingulett oxigén hatástalanításában és a ${ }^{3} \mathrm{Chl}^{*}$ befogásában játszanak szerepet, illetve fotoprotektív mechanizmusok vannak jelen, amelyek a magas fényintenzitás által indukálódnak, és a ${ }^{1} \mathrm{Chl}{ }^{*}$ deaktivációját idézik elő.

Váradi és munkatársai (2003) kutatásai arra világítottak rá, hogy valamennyi vizsgált atrazin-rezisztens gyomfaj, mely hordozta a PSII reakciócentrum D1 proteinjének Ser $_{264} \rightarrow$ Gly mutációját, egy lecsökkent fotoszintetikus hatékonyságú PSII-vel rendelkezett, ami az alacsonyabb fotokémiai kioltásban (qP), mely fokozza a PSII-re ható gerjesztési nyomást (1 qP), a PSII hatásfokának ( $\left.\Phi_{\mathrm{PSII}}\right)$ és a lineáris elektrontranszport sebességének csökkenésében $\left(\mathrm{J}_{\mathrm{ETR}}\right)$ nyilvánult meg. Ezekben a mutánsokban a Zea fényindukált képződése és a termális disszipáció csökkent mértékűnek bizonyult. Mindezen megfigyelésekböl arra következtettek, hogy ezen mutánsok nagyobb fényérzékenységének hátterében az elnyelt fény fotokémiai hasznosulásának és a nem-fotokémiai energia disszipáció arányának kedvezőtlen eltolódása állhat.

Az NPQ molekuláris mechanizmusa csak részben ismert, de kialakulásának feltételei jól behatárolhatóak: a tilakoid lumenének alacsony kémhatása, de-epoxidált xantofillok képződése, a PsbS és más LHCII fehérjék protonációja. Eddigi ismereteink szerint az NPQ kialakulását nukleárisan kódolt faktorok határozzák meg (Funk et al., 1995; Li et al., 2000; Bugos \& Yamamoto, 1996; Jansson, 1999), habár a D1 fehérjét kódoló psbA gén - amely a rezisztens növényekben a mutációt hordozza - a kloroplasztisz genom része (Morden \& Golden, 1989). Nem világos, hogy a D1 protein hogyan járulhat hozzá az antennában végbemenő, hatékony nem-fotokémiai hődisszipáció kialakulásához. 
Napjainkban a vízhiány az egyik legfontosabb abiotikus stressztényezővé vált, amely a növény növekedését/produktivitását limitálja a fotoszintézis gátlásán keresztül. Ismeretes az atrazin-rezisztens növények eltérő hőmérséklet-érzékenysége és adaptációs képessége (Ducruet \& Lemoine, 1985), illetve fokozott fényérzékenységükről egyaránt beszámoltak (Hart \& Stemler, 1990). Természetes körülmények között a vízdeficit gyakran együtt jár a magas hömérséklettel és/vagy a magas fényintenzitással (fénygátlás). Felvetődött az a kérdés, vajon a vízdeficit befolyásolja-e a D1 protein mutáns növények fitneszét.

A célkitüzésekben megfogalmazottak alapján a reciprok keresztezések alanyaként a Solanum nigrum gyomfaj atrazin-szenzitív és rezisztens biotípusait választottam a laboratóriumunkban meglévő D1 protein mutáns gyomfajok közül. Ez a faj eredményesen nevelhető laboratóriumi körülmények között, viszonylag rövid életciklussal bír, jól kezelhető levelei vannak a gázcseremérések szempontjából, valamint a szülő populációk hagyományos keresztezési eljárással laboratóriumi körülmények között könnyen hibridizálhatók. A klorofill $a$ fluoreszcencia indukció és JIP teszt paraméterek, a PSII energia allokációs mintázata, a DNS szekvencia analízis és az immunoblot vizsgálatok, a levélszél öröklődésének nyomonkövetése, a $\mathrm{CO}_{2}$ asszimiláció és vízháztartási paraméterek vizsgálata által kapott eredményeket áttekintve az alábbi megállapításokat teszem:

- A S. nigrum gyomnövény AS és AR szülő biotípusok reciprok keresztezésének sikerességét egy mendeli tulajdonság, a levélszél alak öröklődésének nyomonkövetésével igazoltuk, mely bizonyította az F2 növényi anyag sejtmagi hibrid státuszának meglétét. Az F2 nemzedék levélszél alakjának várható - a Hardy-Weinberg modell szerint számolt szegregációja és a kísérletesen megfigyelt adatok nem különböztek szignifikánsan, mely bizonyította az F2 populáció hibrid státuszának meglétét.

- A vizsgált szülői és hibrid vonalak esetében a D1 protein mutánsokban általánosan megfigyelhető volt az in vivo klorofill fluoreszcencia mérésekből számított PSII lineáris elektrontranszport sebesség, a fotokémiai kioltási koefficiens és a nem-fotokémiai kioltás csökkenése, ezen belül a gyorsan relaxálódó qE komponens csökkenése.

- A reciprok keresztezések eredménye azt mutatta, hogy az NPQ kapacitásbeli különbségeket nem befolyásolták a sejtmagi szabályozó faktorok a hibridekben egészen az F6 generációig. Ezzel összhangban van az az eredmény is, hogy a szekvencia analízis alapján a $S$. nigrum 
AS és AR biotípusaiban azonosak voltak a PsbS fehérjék, azaz nem tartalmaztak aminosav eltérést, és a PsbS és D1 fehérjék expressziójában sem találtunk különbséget.

- A xantofill ciklus aktivitására vonatkozó méréseim alapján megállapítottam, hogy a D1 protein mutációval rendelkező valamennyi AR vonal kb. 20\%-kal csökkent de-epoxidációs képességgel rendelkezett. A xantofill ciklus készletek nagysága között a kétféle biotípusban és hibridjeikben nem mutatható ki különbség. A xantofill ciklus kisebb kapacitásával részben megmagyarázható az NPQ (vagy qE) folyamatok csökkenése az AR biotípusokban.

- Az alkalmazott kétféle PSII energia allokációs modell eredményei alapján megállapítottam, hogy az elnyelt fényenergiának kisebb hányada alakult át kémiailag kötött energiává a fotokémiai töltésszétválasztás során $\left(\Phi_{\mathrm{PSII}}\right)$, amely összefüggésbe hozható az AR vonalak 50\%-kal alacsonyabb fotoszintetikus teljesítmény indexével $\left(\mathrm{PI}_{\mathrm{abs}}\right)$, főképpen a gerjesztési energia befogásának lecsökkent hatékonysága $\left(\varphi_{\mathrm{Po}} /\left(1-\varphi_{\mathrm{Po}}\right)\right)$ következtében. Az AR vonalakra jellemző csökkent fényindukált fotoprotektív NPQ (vagy qE) kapacitás ellenére a regulált hődisszipáció hatásfokát $\left(\Phi_{\mathrm{NPQ}}\right.$ vagy $\left.\Phi_{\mathrm{DL}}\right)$ nem befolyásolta a D1 protein mutáció. A kisebb PSII hatásfok mintegy kompenzációs mechanizmusaként ezáltal a nem-regulált energiaveszteség frakciójának $\left(\Phi_{\mathrm{NO}}\right.$ vagy $\left.\Phi_{\mathrm{E}}\right)$ szignifikáns megnövekedését tapasztaltam a mutáns vonalakban, amely a disszipáció nem fotoprotektív módját jelenti és így közvetlenül hozzájárulhat az AR növények gyengébb fitneszéhez.

- Megállapítottam, hogy az AR vonalak sötétadaptált levelein mért gyors klorofill fluoreszcencia tranziensek (OJIP) analízise egyértelmüen jelezte a PSII müködésének gyengülését az akceptor oldalon (úgymint az excitonok RC-ok általi befogásának hatásfoka, a $\mathrm{Q}_{\mathrm{A}}$ redukált formájának gyors felhalmozódása, ekképpen a PSII RC-ok gyors záródása, az elektrontranszport hatásfoka, az elektrontranszfer fluxusa per RC). A D1 fehérje mutáció csökkentette a PSII müködésének intenzitását, amely jól látszik a $\mathrm{PI}_{\mathrm{abs}} 50 \%$-os esésében, ami hozzájárulhat az alacsonyabb NPQ kialakulásához. Azonban a $\Phi_{\mathrm{NPQ}}$ és a maximális asszimilációs ráta $\left(\mathrm{A}_{\max }\right)$ hasonló értékeire a $S$. nigrum AS és AR vonalaiban ez nem ad magyarázatot. Megállapítottam, hogy a PSI végső akceptorainak redukcióját jellemző JIPteszt paraméterek $\left(\mathrm{RE}_{\mathrm{o}} / \mathrm{RC}, \varphi_{\mathrm{Ro}}, \psi_{\mathrm{Ro}}\right)$ nem különböztek szignifikánsan a kétféle biotípusban és hibridjeikben. A $\delta_{\text {Ro }}$ paraméter azonban, mely annak a valószínüségét fejezi ki, amellyel egy elektron a köztes elektron akceptorok felöl a PSI végső akceptorokhoz eljut, az AR biotípusokban jelentősen megnövekedett. Ez feltételezhetően kompenzálhatja a PSII 
akceptor oldali alacsonyabb elektronáram sebességet és a $\mathrm{PI}_{\mathrm{abs}}$-t, és hasonló $\mathrm{PI}_{\text {total }}$ értékeket eredményez a $S$. nigrum biotípusaiban.

Az eredményeink azt mutatják, hogy az általunk vizsgált klorofill fluoreszcencia tulajdonságokat, úgymint a gyors Chl fluoreszcencia tranzienseket és a JIP teszt paramétereket, a PSII antennája által elnyelt energia allokációs mintázatot és az NPQ-t a D1 protein befolyásolja az AS és AR biotípusú $S$. nigrum növények leveleiben. Az erősen konzervált D1 protein szerepét az elnyelt többletenergia nem-fotokémiai hődisszipációjának hatékony kialakulásában esszenciálisnak véljük, ahogyan ezt a kloroplasztisz genomban kódolt S264G D1 protein mutáció és az alacsony NPQ (vagy qE) kapacitás együtt-öröklődése igazolta.

A vízdeficit hatására vonatkozó megállapítások:

- Megállapítottam, hogy az aktinikus fényre adott válaszgörbék alapján, valamint az intercelluláris $\mathrm{CO}_{2}$ koncentrácó függvényében meghatározott, egységnyi levélfelületre vonatkoztatott $\mathrm{CO}_{2}$ asszimilációs ráták gyakorlatilag nem különböztek a kétféle szülő biotípusban. A vízháztartási paraméterek értékei, sztóma konduktancia, levél relatív víztartalom, levél vízpotenciál $\left(\mathrm{g}_{\mathrm{s}}, \mathrm{RWC}, \Psi\right)$ szintén nagyon hasonlóak voltak a kétféle biotípusban, és az AR biotípus alacsonyabb sztómasürüsége nem befolyásolta $\mathrm{a}_{\mathrm{s}} \mathrm{-t}$.

- A progresszív vízhiány mindkét biotípusban előidézte a sztómák záródását, csökkentve a kloroplasztiszba jutó $\mathrm{CO}_{2}$ mennyiségét, $\mathrm{s}$ mindez a g $\mathrm{g}_{\mathrm{s}}$, az intercelluláris $\mathrm{CO}_{2}$ koncentráció és a $\mathrm{CO}_{2}$ asszimiláció intenzitásának csökkenésében mutatkozott meg. Ezt követően néhány nap késéssel az egyéb vízháztartási paraméterek ( $\Psi$, RWC) értékeiben is csökkenést figyeltem meg. Az asszimilációs ráta csökkenésével párhuzamosan a fotorespiráció mértékének fokozódását figyeltem meg progresszív vízhiány alatt. Megállapítottam, hogy az AR biotípus a vízháztartási paraméterek és a $\mathrm{CO}_{2}$ asszimiláció alapján toleránsabb volt a vízmegvonással szemben. A vízháztartási paraméterek és az asszimilációs ráta csökkenése később következett be az AR biotípusban, mint az AS párjában. Ezt tükrözte a kisebb mértékü fotorespiráció, a magasabb maximális asszimilációs ráta $\left(\mathrm{A}_{\max }\right)$, a nagyobb karboxilációs hatékonyság $(\varepsilon)$ és a RuBP nagyobb 
regenerálódási sebessége $\left(\mathrm{J}_{\max }\right)$ is. A vízmegvonás előrehaladtával a kétféle biotípus közötti különbség mérséklődött, illetve a közepes vízhiány szakaszában el is tünt.

- A reciprok keresztezésekből származó F2 hibridekkel folytatott vizsgálatok eredményei alapján megállapítom, hogy a szülő AR biotípus szárazsággal szembeni nagyobb toleranciája nem köthető a D1 protein mutációhoz, mivel a szülö populációkban meglévő tulajdonságok az F2 nemzedékben elmosódtak. Feltételezem, hogy az általam tapasztalt különbség a szülő populációknak az élőhelyhez való alkalmazkodása során a sejtmagi genetikai háttér módosulásával alakulhatott ki, vagy a számos pleiotrop hatás egyike, amely a szelektálódott populációban az önbeporzás következtében fennmaradhatott. Megállapítom továbbá, hogy az atrazin-rezisztens biotípus rosszabb fitnesze nem magyarázható a vízhiánnyal szembeni tolerancia-csökkenésével.

- A PSII hatásfoka $\left(\Phi_{\text {PSII }}\right)$ és a lineáris elektrontranszport sebessége mindkét erősen vízhiányos biotípusban és hibridjeikben közel azonos értékekre estek vissza. Valamennyi AR vonalban drasztikus NPQ növekedést figyeltem meg, míg a vad-típusú AS párjaikban kisebb mértékü volt ez az emelkedés. Meglepő módon a $\Phi_{\mathrm{NPQ}}$ és az NPQ összefüggést mutatott, nem úgy, mint a kontroll növények esetében. A $\Phi_{\mathrm{NO}}$, mint komplementer folyamat, az AR vonalakban kissé lecsökkent, míg a vad típusú párjaikban megemelkedett a jó vízellátású kontrolljaikhoz képest.

- A progresszív vízhiánynak kitett szülő populációk és megfelelő hibridjeik a vizsgált fluoreszcencia tulajdonságokban nem különböztek egymástól, így e folyamatok a D1 protein mutációhoz köthetők, szemben a $\mathrm{CO}_{2}$ asszimilációbeli különbségekkel. A vízhiányos mintában a rehidratálás után a plasztiszszerkezet helyreállását, illetve a kontrollokhoz hasonló PSII energia allokációs mintázat és NPQ kinetika visszaállását tapasztaltam mindkét biotípusban.

Úgy tünik tehát, hogy az AR vonalakban a klorofill fluoreszcencia vizsgálatok alapján az erős szárazság által indukált fotoprotekciós folyamatok hatékonyabban müködhetnek, mint az AS párjaikban. Ezt részben magyarázhatná a PSI körüli ciklikus elektrontranszport fokozódása, amely a $\Delta \mathrm{pH}$ létrehozásával hozzájárul az NPQ fenntartásához, és mérsékli a PSII-n lévő gerjesztési nyomást. Szárazság alatt a regulált termális disszipáció fokozódása a fénybegyüjtő komplexekben valamiképpen magában foglalja a xantofill ciklust és a lutein ciklust, habár 
utóbbi szerepe nem teljesen világos még. A kloroplasztisz vízdeficit hatására végbemenő szerkezeti újra-rendeződése szintén hozzájárulhat valamilyen formában a hatékonyabb hődisszipáció kialakulásához az AR növényben. Ezt alátámasztani látszik az a tény, hogy a rehidratálás után a plasztiszszerkezet helyreáll, melynek következtében visszaáll a kontrollokhoz hasonló PSII energia allokációs mintázat és NPQ kinetika mindkét biotípusban és hibridjeikben. Azonban e jelenség magyarázatához további vizsgálatokra lenne szükségünk. 


\section{SUMMARY}

In the course of oxygenic photosynthesis the molecular structure of PSII should satisfy two antagonistic criteria. On one hand it should be organized so that is suitable for the efficient collection of light and to transferring the excitation energy to the reaction centres to drive the electron transport chain. On the other hand the excited chlorophyll molecules in the presence of molecular oxygen represent a potentially lethal environment which can irreversibly damage the proteins, lipids and other components of the photosynthetic membrane. In order to counteract this process some sort of photoprotective mechanism had to be evolved which comes into effect under high light condition and deactivates singlet excited chlorophylls $\left({ }^{1} \mathrm{Chl}^{*}\right)$. Also, certain cofactors of the photosynthetic machinery, such as carotenoids, play a significant role in scavenging singlet oxygen $\left({ }^{1} \mathrm{O}_{2}{ }^{*}\right)$ and/or in relaxation of triplet excited chlorophylls $\left({ }^{3} \mathrm{Chl}^{*}\right)$.

It has been shown by Váradi and co-workers (2003) that all of the atrazine-resistant weed species in their investigation, which carried a mutation of $\mathrm{Ser}_{264} \rightarrow$ Gly on their D1 protein of PSII reaction centre, exhibited diminished PSII activity. This was described by a decrease in photochemical quenching $(\mathrm{qP})$, which also means higher excitation pressure on PSII $(1-q \mathrm{q})$, and by a decrease of both the PSII efficiency $\left(\Phi_{\mathrm{PSII}}\right)$ and the linear electron transport rate $\left(\mathrm{J}_{\mathrm{ETR}}\right)$. In these mutants the light-induced formation of zeaxanthin and the thermal dissipation of excess energy were both impaired. The authors concluded that in these mutants the increased sensitivity to light can be attributed to the non-favourable change in the ratio of photochemical utilization and non-photochemical quenching (NPQ) of the absorbed light.

Although the exact molecular mechanism of NPQ is not yet fully understood several of its preconditions are well known, such as acidification of the thylakoid lumen, de-epoxidation of the xantophyll-cycle pigments and/or protonation of PsbS and other light-harvesting complexes (LHCs). There is a general consensus that NPQ is controlled by factors that are encoded in the nucleus (Funk et al., 1995; Bugos \& Yamamoto, 1996; Jansson, 1999; Li et al., $2000)$. Since the D1 protein encoding $p s b A$ gene, which carries the mutation in the atrazineresistant plants, is localized in the chloroplast genome (Morden \& Golden, 1989), it is not 
entirely clear in what way the D1 protein can contribute to the formation of efficient nonphotochemical dissipative processes in the antenna.

Nowadays, drought stress has become one of the most important abiotic factors, which limits the growth and/or productivity of the plants via inhibiting the photosynthetic machinery. The different sensitivity of the atrazine-resistant plants to the ambient temperature and their ability to adapt to various environmental conditions are well documented (Ducruet \& Lemoine, 1985) as well as their increased susceptibility to high light (Hart \& Stemler, 1990). In their natural environment the lack of water often goes hand in hand with high ambient temperature and/or elevated light levels (photoinhibition). This led us to raise the question whether the drought stress can influence the fitness of the D1 protein mutant plants.

In order to pursue this investigation I selected the atrazine-sensitive and resistant (AS and AR) biotypes of Solanum nigrum out of the D1 protein mutant weed species that we had access to in our laboratory. This particular weed can be efficiently grown in laboratory conditions; they have a fairly short life-cycle, their leaves are very suitable for gas exchange measurements and the parent populations can easily be hybridized by standard cross breeding methods. Throughout this investigation I have focussed my interest on the chlorophyll $a$ fluorescence induction and JIP test parameters, the energy allocation pattern in PSII, DNA sequence and immunoblot analysis, the inheritance of leaf margin, $\mathrm{CO}_{2}$ assimilation and the properties of water balance. The results can be summarized as follows:

- The turn out of the reciprocal crossing of the AS and AR biotypes of S. nigrum were analyzed by following the inheritance of a Mendelian trait of the plants, the leaf margin. Since the expected segregation of leaf margin type in F2 - calculated according to the Hardy-Weinberg model - and the observed numbers did not differ significantly, it thus justifies the hybrid status of the F2 population.

- Using in vivo Chla fluorescence techniques I managed to show, in the D1 mutants of both the parent and their hybrid lines, a decrease in the PSII linear electron transport rate, in the photochemical quenching parameter, and a drop off in the NPQ and its fast relaxing qE component, in particular.

- The results of the reciprocal crossings proved that the differences in the NPQ capacity between the AS and AR types is not influenced by the regulatory factors in the nuclei of 
the hybrids down to the F6 generations. This finding is in accordance with the DNA analysis of the AS and AR biotypes of $S$. nigrum, which showed no alteration in the amino acid sequence of the PsbS protein and there were no differences in the expression of the PsbS and D1 proteins, either.

- Investigating the xanthophyll-cycle activity I found that all AR lines, possessing the mutation on the D1 protein, exhibited a roughly $20 \%$ decrease in their aptitude for deepoxidation, however, in the two biotypes and their hybrids, there was no significant difference in the size of their xanthophyll-cycle pool. The reduced capacity of the xanthophyll-cycle in the AR biotypes can partially explain the impaired NPQ (or qE) processes found in these plants.

- The two models used in determining the energy allocation pattern in PSII led me to conclude that during the photosynthetic charge separation a smaller fraction of the absorbed light energy was converted to chemically stored energy $\left(\Phi_{\mathrm{PSII}}\right)$ in the AR lines, which can be related to the $50 \%$ lower photosynthetic performance index $\left(\mathrm{PI}_{\mathrm{abs}}\right)$, and in particular, the drop in the efficiency in capturing the excitation energy $\left(\varphi_{\mathrm{Po}} /\left(1-\varphi_{\mathrm{Po}}\right)\right)$. Despite the lower light induced photoprotective NPQ (or qE) capacity of the AR lines the efficiency of the regulated thermal dissipation of the excitation energy $\left(\Phi_{\mathrm{NPQ}}\right.$ or $\left.\Phi_{\mathrm{DL}}\right)$ was not affected by the mutation on the D1 protein. As a compensatory mechanism to counteract the lower PSII efficiency in the mutant lines a significant increase in the non-regulated energy losses $\left(\Phi_{\mathrm{NO}}\right.$ or $\Phi_{\mathrm{E}}$ ), which represents the non-photoprotective way of energy dissipation, was found, potentially contributing to the lower fitness of the AR plants.

- The analysis of the fast Chl $a$ fluorescence transients (OJIP) of the dark-adapted leaves of the AR biotypes revealed a decline in PSII performance on the acceptor side (as indicated by the decreasing efficiency of the RCs in capturing the excitation energy, the fast accumulation of reduced $\mathrm{Q}_{\mathrm{A}}$ and the fast closure of PSII RCs, the efficiency of electron transport and the electron transfer flux per RC). The mutation on the D1 protein impaired the functioning of PSII, as implied from the 50\% decline in $\mathrm{PI}_{\mathrm{abs}}$, which, in turn, can contribute to the lower NPQ capacity. However, this cannot explain the similar values of $\Phi_{\mathrm{NPQ}}$ and maximal assimilation rate $\left(\mathrm{A}_{\max }\right)$ in the AS and AR lines of $S$. nigrum. The JIP test parameters $\left(\mathrm{RE}_{\mathrm{o}} / \mathrm{RC}, \varphi_{\mathrm{Ro}}, \psi_{\mathrm{Ro}}\right)$, characterizing the reduction of the final electron acceptors of PSI, were found to be within statistical significance in both biotypes and in 
their hybrids. However, the $\delta_{\text {Ro }}$ parameter, which represents the efficiency to transfer an electron from the intersystem electron carriers to reduce the final electron acceptors on the acceptor side of PSI, has increased significantly in the AR lines. This, presumably, can compensate the slower electron flow rate on the acceptor side of PSII as well as the lower $\mathrm{PI}_{\text {abs, }}$, and yields similar $\mathrm{PI}_{\text {total }}$ values in both biotypes of S. nigrum.

These results show, that the $\mathrm{D} 1$ protein has an influence on the Chl $a$ fluorescence properties, such as the fast Chl fluorescence transients and the JIP test parameters, as well as on the energy allocation patterns in PSII and the NPQ of both the AS and AR biotypes of S. nigrum. We believe that the highly conserved D1 protein plays an essential role in the formation of thermal dissipation processes to de-activate the excess excitation energy, as it was demonstrated by the co-inheritance of the S264G mutation on the D1 protein, which is encoded in the chloroplast genome, and the low levels of NPQ (or qE) capacity.

The main findings of our investigation concerning the effects of drought stress are as follows:

- The results show that the $\mathrm{CO}_{2}$ assimilation rates per unit leaf surface area, based on the evaluation of the actinic light response curves as a function of intercellular $\mathrm{CO}_{2}$ concentration, did not differ significantly in the two parent biotypes. The water balance parameters, such as the stomatal conductance $\left(\mathrm{g}_{\mathrm{s}}\right)$, the relative water content of the leaves (RWC) and the water potential $(\Psi)$, were very much alike in the two biotypes and even the larger stoma density in the AR biotype had practically no effect on $\mathrm{g}_{\mathrm{s}}$.

- In both biotypes the progressive water famine led to the closure of the stomata, preventing $\mathrm{CO}_{2}$ intake by the chloroplasts, which manifested in a decrease of the intercellular $\mathrm{CO}_{2}$ concentration as well as a drop in $\mathrm{g}_{\mathrm{s}}$ and the in $\mathrm{CO}_{2}$ assimilation rate. This was followed, after a few days, by a decline in other water balance parameters (RWC, $\Psi$ ). Parallel with the decrease in the $\mathrm{CO}_{2}$ assimilation rate, a rise in the extent of photorespiration was observable as a consequence of the gradual water deficit. Based on the water balance parameters and the $\mathrm{CO}_{2}$ assimilation rate one can conclude that the AR biotype was more tolerant towards the detention of water: both the water balance parameters and the $\mathrm{CO}_{2}$ assimilation rate started decreasing somewhat later in the AR biotype than in its AS 
counterpart. This was also substantiated by a weaker photorespiration, a higher rate of maximal assimilation $\left(\mathrm{A}_{\max }\right)$, increased carboxylation efficiency $(\varepsilon)$ and a higher regeneration rate of RuBP $\left(\mathrm{J}_{\max }\right)$. The difference between the two biotypes gradually diminished with the progression of water detention and it practically disappeared during the intermediate phase of dehydration.

- The results of the investigations with the F2 generation of the reciprocal cross breeding shows that the higher drought tolerance of the parent population of the AR biotype cannot be linked to the D1 mutation as the traits present in the parent population become blurred in the F2 generation. We argue that the differences seen in the parent population are the consequence of their adaptation to the environment, causing alterations in the genetic material of the nuclei, or the result of one of the several pleiotropic effects, which could sustain in the selected population via the self-pollination. We also conclude that the lower fitness of the AR lines cannot be explained by their weakened tolerance towards water detention.

- In both biotypes and their hybrids, which suffered severe dehydration, the magnitude of PSII efficiency and that of the linear electron transport rate drops back to similar levels. The NPQ has increased dramatically in all AR lines, whereas the increase was much less pronounced in their AS counterparts. Surprisingly, we could observe a correlation between $\Phi_{\mathrm{NPQ}}$ and NPQ, unlike in the case of their well watered controls. The levels of $\Phi_{\mathrm{NO}}$, representing a complementary process, were found to be somewhat decreased in the AR lines, while an increase was observed in the wild-type plants as compared to their well watered control pairs.

- As the fluorescence properties of the parent populations, which went through progressive dehydration, and their corresponding hybrids were found to be very similar the aforementioned observations can be linked to the mutation on the D1 protein, unlike the differences in $\mathrm{CO}_{2}$ assimilation. After rehydration the membrane structure of chloroplast was largely restored and similarly the energy allocation pattern of PSII and the NPQ kinetics were found to be much like to those observed in the control plants, in both biotypes. 
Based on the fluorescence parameters it seems reasonable to conclude that the photoprotection mechanisms induced by severe water detention are more efficient in the AR lines than in their AS counterparts. This can be, up to a certain extent, substantiated by the enhancement of the cyclic electron flow around the PSI, which can contribute to maintaining the NPQ by building up a transmembrane $\Delta \mathrm{pH}$, hence lessening the excitation pressure on PSII. The augmentation of the regulated thermal dissipative processes in the light-harvesting complex under drought stress conditions can somehow involve the xanthophyll- and lutein-cycles, however, the exact role of the latter in this process has not yet fully understood. In the AR plants the structural rearrangement of chloroplasts, as a result of water detention, can also contribute, to some extent, to a more efficient thermal dissipation mechanism. This can be supported by the fact that, after re-hydration, the membrane structure of the chloroplasts is mostly restored, which leads to similar energy allocation patterns in PSII and NPQ kinetics in both biotypes and in their hybrids, as compared to those in their controls. However, in order to gain a better understanding of this phenomenon further investigations are required. 


\section{IRODALOMJEGYZÉK}

Adams WW, Demmig-Adams B, Winter K (1990) Relative contributions of zeaxanthin-related and zeaxanthin-unrelated types of 'high-energystate' quenching of chlorophyll fluorescence in spinach leaves exposed to various environmental conditions. Plant Physiol 92: 302-309

Ahn TK, Avenson T, Ballottari M, Cheng YC, Niyogi KK, Bassi R, Fleming GR (2008) Architecture of a charge-transfer state regulating light harvesting in a plant antenna protein. Science 320: 794-797

Allen JF, Bennett J, Steinback KE, Arntzen CJ (1981) Chloroplast protein phosphorylation couples plastoquinone redox state to distribution of excitation energy between photosystems. Nature 291: 1-5

Amarie S, Standfüss J, Barros T, Kühlbrandt W, Dreuw A, Wachtveitl J (2007) Carotenoid radical cations as a probe for the molecular mechanism of nonphotochemical quenching in oxygenic photosynthesis. $\mathrm{J}$ Phys Chem B 111: 3481-3487

Andersson B, Barber J (1996) Mechanisms of photodamage and protein degradation during photoinhibition of photosystem II. In: Baker NR ed. Photosynthesis and the Environment. Kluwer Academic Publ, Dordrecht, pp 101-121

Andersson J, Walters RG, Horton P, Jansson S (2001) Antisense inhibition of the photosynthetic antenna proteins CP29 and CP26: Implications for the mechanism of protective energy dissipation. Plant Cell 13: 1193-1204

Andersson J, Wentworth M, Walters RG, Howard CA, Ruban AV, Horton P, Jansson S (2003) Absence of the Lhcb1 and Lhcb2 proteins of the light-harvesting complex of photosystem II - effects on photosynthesis, grana stacking and fitness. The Plant Journal 35: 350-361

Anderson JM, Chow WS, Goodchild DJ (1988) Thylakoid membrane organisation in sun/shade acclimation. Aust J Plant Physiol 15: 11-26

Anderson JM, Chow WS, Park YI (1995) The grand design of photosynthesis: acclimation of the photosynthetic apparatus to environmental cues. Photosynth Re; 46: 129-139

Anderson JM, Osmond B (2001) Sun-shade responses: Compromises between acclimation and photoinhibition. In: Kyle DJ, Osmond B, Arntzen CJ eds. Photoinhibition. Elsevier, Amsterdam, pp 138

Arntzen CJ, Ditto CL, Brewer PE (1979) Chloroplast membrane alterations in triazine resistant Amaranthus retroflexus biotypes. Proc Natl Acad Sci USA 76: 278-282

Arntzen CJ, Pfister K, Steinback KE (1982) The mechanism of chloroplast triazine resistance: alterations in the site of herbicide action. In: LeBaron HM, Gressel J eds. Herbicide Resistance in Plants. John Wiley and Sons, New York, pp 185-214

Aro EM, Virgin I, Andersson B (1993) Photoinhibition of photosystem II: inactivation, protein damage and turnover. Biochim Biophys Acta 1143: 113-134

Asada K (1994) Mechanisms for scavenging reactive molecules generated in chloroplasts under light stress. In: Baker NR, Bowyer JR eds. Photoinhibition of Photosynthesis: From Molecular Mechanisms to the Field. BIOS Sci Publ, Oxford, pp 129-142

Asada K (1999) The water-water cycle in chloroplast: Scavenging of active oxygens and dissipation of excess photons. Annu Rev Plant Physiol Plant Mol Biol 50: 601-639

Assmann SM (1988) Enhancement of the stomatal response to blue light by red light, reduced intracellular concentrations of $\mathrm{CO}_{2}$, and low vapor pressure differences. Plant Physiol. 87: 226-237

Avenson TJ, Ahn TK, Zigmantas D, Niyogi KK, Li Z, Ballotarri M, Bassi R, Fleming GR (2008) Zeaxanthin radical cation formation in minor light harvesting complexes of higher plant antenna. J Biol Chem 283: 3550-3558

Avenson TJ, Ahn TK, Niyogi KK, Ballottari M, Bassi R, Fleming GR (2009) Lutein can act as a switchable charge-transfer quencher in the CP26 light-harvesting complex. J Biol Chem 284: 2830-2835

Bajkán Sz, Váradi Gy, Balogh M, Domonkos Á, Kiss GyB, Kovács L, Lehoczki E (2010) Conserved structure of the chloroplast-DNA encoded D1 protein is essential for effective photoprotection via nonphotochemical thermal dissipation in higher plants. Mol Genet Genomics 284: 55-63 
Bajkán Sz, Várkonyi Zs, Lehoczki E (2011) Comparative study on energy partitioning in photosystem II of two Arabidopsis thaliana mutants with reduced non-photochemical quenching capacity. Acta Physiol Plant (közlésre elfogadva)

Barber J, Andersson B (1992) Too much of a good thing: light can be bad for photosynthesis. Trends Biochem Sci 17: 61-66

Benhassaine-Kesri G, Aid F, Demandre C, Kader JC, Mazliak P (2002) Drought stress affects chloroplast lipid metabolism in rape (Brassica napus) leaves. Physiol Plant 115: 221-227

Bennett J (1977) Phosphorylation of chloroplast membrane proteins. Nature 269: 344-346

Bennett J (1979) Chloroplast phosphoproteins. The protein kinase of thylakoid membranes is lightdependent. FEBS Lett 103: 342-344

Bergantino E, Segalla A, Brunetta A, Teardo E, Rigoni F, Giacometti GM, Szabo I (2003) Light- and pHdependent structural changes in the PsbS subunit of photosystem II. Proc Natl Acad Sci USA 100: $15265-15270$

Bernacchia G, Furini A (2004) Biochemical and molecular responses to water stress in resurrection plants. Physiol Plant 121: 175-181

Betterle N, Ballottari M, Zorzan S, de Bianchi S, Cazzaniga S, Dall'Osto L, Morosinotto T, Bassi R (2009) Light induced dissociation of an antenna hetero-oligomer is needed for non-photochemical quenching induction. J Biol Chem 284: 15255-15266

Beversdorf WD, Hume DJ, Donnelly-Vanderloo MJ (1988) Agronomic performance of triazine-resistant and susceptible reciprocal spring canola hybrids. Crop Sci 28: 932-934

Bilger W, Björkman O (1990) Role of the xanthophyll cycle in photoprotection elucidated by measurements of light-induced absorbance changes, fluorescence and photosynthesis in Hedera canariensis. Photosynth Res 25: 173-185

Bilger W, Björkman O (1994) Relationships among violaxanthin deepoxidation, thylakoid membrane conformation, and nonphotochemical chlorophyll fluorescence quenching in leaves of cotton (Gossypium hirsutum L.). Planta 193: 238-246

Bilger W, Schreiber U, Bock M (1995) Determination of the quantum efficiency of PS II and of nonphotochemical quenching of chlorophyll fluorescence in the field. Oecologia 102: 425-432

Björkman O, Demmig B (1987) Photon yield of $\mathrm{O}_{2}$ evolution and chlorophyll fluorescence characteristics at $77 \mathrm{~K}$ among vascular plants of diverse origins. Planta 170: 489-504

Björkman O, Powles SB (1987) Leaf movement in the shade species Oxalis oregana L I. Response to light level and light quality. Carneg Inst Wash Yearb 80: 59-62

Bohnert HJ, Shen B (1999) Transformation and compatible solutes. Sci Hortic 78: 237-260

Bonaventura C, Mayers J (1969) Fluorescence and oxygen evolution from Chlorella pyrenoidosa. Biochim Biophys Acta 189: 366-383

Bonente G, Howes BD, Caffarri S, Smulevich G, Bassi R (2008) Interactions between the photosystem II subunit PsbS and xanthophylls studied in vivo and in vitro. J Biol Chem 283: 8434-8445

Bota J, Medrano H, Flexas J (2004) Is photosynthesis limited by decreased Rubisco activity and RuBP content under progressive water stress? New Physiologist 162: 671-681

Bowes JM, Crofts AR, Arntzen CJ (1980) Redox reactions on the reducing side of photosystem II in chloroplasts with altered herbicide biding properties. Arch Biochem Biophys 200: 303-308

Briantais JM, Vernotte C, Picaud M, Krause GH (1979) A quantitative study of the slow decline of chlorophyll a fluorescence in isolated chloroplasts. Biochim Biophys Acta 548: 128-138

Briantais JM, Ducruet JM, Hodges M, Krause GH (1992) The effects of low temperature acclimation and photoinhibitory treatments on photosystem- 2 studied by thermoluminescence and fluorescence decay kinetics. Photosynth Res 31: 1-10

Briantais JM (1994) Light-harvesting chlorophyll a-b complex requirement for regulation of photosystem II photochemistry by non-photochemical quenching. Photosynth Res 40: 287-294

Brugnoli E, Björkman O (1992) Growth of cotton under continuous salinity stress-influence on allocation pattern, stomatal and nonstomatal components of photosynthesis and dissipation of excess light energy. Planta 187: 335-47

Bugos RC, Yamamoto HY (1996) Molecular cloning of violaxanthin de-epoxidase from romaine lettuce and expression in Escherichia coli. Proc Natl Acad Sci USA 93: 6320-6325 
Bunce JA (1981) Relationships between maximum photosynthetic rates and photosynthetic tolerance of low leaf water potentials. Can J Bot 59: 769-774

Burke JJ, Wilson RF, Swafford JR (1982) Characterization of chloroplasts isolated from triazine-susceptible and triazine-resistant biotypes of Brassica campestris L. Plant Physiol 70: 24-29

Caffarri S, Croce R, Breton J, Bassi R (2001) The major antenna complex of photosystem II has a xanthophyll binding site not involved in light harvesting. J Biol Chem 38: 35924-35933

Caldwell CR, Whitman CE (1987) Temperature-induced protein conformational changes in barley root plasma membrane-enriched microsomes. I. Effect of temperature on membrane protein and lipid mobility. Plant Physiol 84: 918-923

Cailly AL, Rizza F, Genty B, Harbinson J (1996) Fate of excitation at PS II in leaves. The nonphotochemical side. Plant Physiol Biochemistry Special issue, pp 86

Castrillo M, Fernández D, Calcagno AM, Trujillo I, Guenni L (2001) Responses of ribulose-1,5bisphosphate carboxylase, protein content, and stomatal conductance to water deficit in maize, tomato, and bean. Photosynthetica 39: 221-226

Chaves MM (1991) Effects of water deficits on carbon assimilation. J Exp Bot 42: 1-16

Chaves MM, Maroco JP, Pereira JS (2003) Understanding plant responses to drought - from genes to the whole plant. Funct Plant Biol 30: 239-264

Chaves MM, Oliveira MM (2004) Mechanisms underlying plant resilience to water deficits: prospects for water-saving agriculture. J Exp Bot 55: 2365-2384

Chow WS, Anderson JM Hope AB (1988) Variable stoichiometries of photosystem-II to photosystem-I reaction centers. Photosynth Res 17: 277-281

Chow WS (1994) Photoprotection and photoinhibitory damage. In: Bittar EE, Barber J eds. Advanves in Molecular and Cell Biology, Vol 10. JAI Press, London, pp 151-196

Cornic G, Gouallec JL, Briantais JM, Hodges M (1989) Effect of dehydration and high light on photosynthesis of two $\mathrm{C}_{3}$ plants (Phaseolus vulgaris L. and Elatostema repens (Lour.) Hall f.). Planta 177: 84-90

Cornic G, Briantais JM (1991) Partitioning of photosynthetic electron flow between $\mathrm{CO}_{2}$ and $\mathrm{O}_{2}$ reduction in a $\mathrm{C}_{3}$ leaf (Phaseolus vulgaris L.) at different $\mathrm{CO}_{2}$ concentrations and during drought stress. Planta 183: $178-184$

Cornic G, Fresneau S (2002) Photosynthetic carbon reduction and carbon oxidation cycles are the main electron sinks for photosystem II activity during a mild drought. Ann Bot 89: 887-894

Crouchman S, Ruban AV, Horton P (2006) PsbS enhances nonphotochemical fluorescence quenching in the absence of zeaxanthin. FEBS Lett 580: 2053-2058

Curwiel VB, van Rensen JJS (1993) Influence of photoinhibition on electron transport and photophosphorylation of isolated chloroplasts. Physiol Plant 89: 97-102

da Silva JM, Arrabaça MC (2004) Contributions of soluble carbohydrates to the osmotic adjustment in the $\mathrm{C}_{4}$ grass Setaria sphacelata: a comparison between rapidly and slowly imposed water stress. J Plant Physiol 161: 551-555

Darkó É, Váradi Gy, Hargitai A, Nagy E, Lehoczki E (1995) Comparison of photosensitivity of the photosynthetic apparatus in different light adapted atrazine-resistant and susceptible biotypes from Conyza canadensis (L.) Cronq. In: Mathis P ed. Photosynthesis from light to Biosphere, Vol IV. Kluwer Academic Publ, Dordrecht/Boston/London, pp 191-194

Darkó É, Váradi Gy, Lehoczki E (1996) Atrazine-resistant biotypes of Conyza canadensis have altered fluorescence quenching and xanthophyll cycle pattern. Plant Physiol Biochem 34: 843-852

Darkó É, Váradi Gy, Lemoine Y, Lehoczki E (2000) Defensive strategies against high-light stress in wild and D1 protein mutant biotypes of Erigeron canadensis. Aust J Plant Physiol 27: 325-333

Darmency H, Pernes J (1989) Agronomic performance of a triazine-resistant foxtail millet (Setaria italica (L.) Beauv.). Weed Res 29: 147-150

Davies WJ, Zhang J (1991) Root sygnals and the regulation of growth and development of plant in drying soil. Annu Rev Plant Physiol Plant Mol Biol 42: 55-76

de Bianchi S, Dall'Osto L, Tognon G, Morosinotto T, Bassi R (2008) Minor antenna proteins CP24 and CP26 affect the interactions between photosystem II subunits and the electron transport rate in grana membranes of Arabidopsis. Plant Cell 20: 1012-1028 
Demmig B, Winter K, Krüger A, Czygan FC (1987) Photoinhibition and zeaxanthin formation in intact leaves: a possible role of the xanthophyll cycle in the dissipation of excess light energy. Plant Physiol 84: $218-224$

Demmig-Adams B (1990) Carotenoids and photoprotection in plants: a role for the xanthophyll zeaxanthin. Biochim Biophys Acta 1020: 1-24

Demmig-Adams B, Adams WWIII (1992) Photoprotection and other responses of plants to high light stress. Annu Rev Plant Physiol Plant Mol Biol 43: 599-626

Demmig-Adams B, Adams WWIII (1996) The role of xanthophyll cycle carotenoids in the protection of photosynthesis. Trends Plant Sci 1: 21-26

Demmig-Adams B, Adams WW, Barker DH, Logan BA, Bowling DR, Verhoeven AS (1996) Using chlorophyll fluorescence to assess the fraction of absorbed light allocated to thermal dissipation of excess excitation. Physiol Plant 98: 253-264

Dominici P, Caffarri S, Armenante F, Ceoldo S, Crimi M, Bassi R (2002) Biochemical properties of the PsbS subunit of photosystem II either purified from chloroplast or recombinant. J Biol Chem 277: 22750-22758

Dreuw A, Wormit M (2008) Simple replacement of violaxanthin by zeaxanthin in LHCII does not cause chlorophyll fluorescence quenching. J Inorg Biochem 102: 458-465

Ducruet J, Lemoine Y (1985) Increased heat sensitivity of the photosynthetic apparatus in triazine-resistant biotypes from different plant species. Plant Cell Physiol 26: 419-429

Ducruet JM, Roman M, Ortega JM, Janda T (2005) Role of the oxidized secondary acceptor $\mathrm{Q}_{\mathrm{B}}$ of photosystem II in the delayed 'afterglow' chlorophyll luminescence. Photosynth Res 84: 161-166

El-Lithy ME, Rodrigues GC, van Rensen JJS, Snel JF, Dassen HJ, Koornneef M, Jansen MA, Aarts MG, Vreugdenhil D (2005) Altered photosynthetic performance of a natural Arabidopsis accession is associated with atrazine resistance. J Exp Bot 56: 1625-1634

Farquhar GD, Sharkey TD (1982) Stomatal conductance and photosynthesis. Annu Rev Plant Physiol 33: 317-345

Farquhar GD, von Caemmerer S, Berry JA (1990) A biochemical model of photosynthetic $\mathrm{CO}_{2}$ assimilation in leaves of $\mathrm{C}_{3}$ species. Planta 149: 78-90

Färber A, Young AJ, Ruban AV, Horton P, Jahns P (1997) Dynamics of xanthophyll-cycle activity in different antenna subcomplexes in the photosynthetic membranes of higher plants. Plant Physiol 115: $1609-1618$

Fedtke C (1979) Physiological responses of soybean (Glycine max) plants to metribuzin. Weed Sci 27: 192195

Feild TS, Lee DW, Holbrook NM (2001) Why leaves turn red in autumn: the role of anthocyanins in senescing leaves of red-osier dogwood. Plant Physiol 127: 566-574

Finazzi G, Johnson GN, Dall'Osto L, Joliot P, Wollman FA, Bassi R (2004) A zeaxanthin-independent nonphotochemical quenching mechanism localized in the photosystem II core complex. Proc Natl Acad Sci USA 101: $12375-12380$

Flexas J, Medrano H (2002) Drought inhibition of photosynthesis in C3 plants: stomatal and non-stomatal limitations revisited. Ann Bot 89: 183-189

Flexas J, Bota J, Loreto F, Cornic G, Sharkey TD (2004) Diffusive and metabolic limitations to photosynthesis under drought and salinity in C3 plants. Plant Biology 6: 269-279

Flexas J, Ribas-Carbó M, Bota J, Galmés J, Henkle M, Martínez-Cañellas S, Medrano H (2006) Decreased Rubisco activity during water stress is not induced by decreased relative water content but related to conditions of low stomatal conductance and chloroplast $\mathrm{CO}_{2}$ concentration. New Phytologist 172: 7382

Flexas J, Diaz-Espejo A, Galmés J, Kaldenhoff R, Medrano H, Ribas-Carbo M (2007) Rapid variations of mesophyll conductance in response to changes in $\mathrm{CO}_{2}$ concentration around leaves. Plant Cell Environ 30: $1284-1298$

Flexas J, Ribas-Carbó M, Diaz-Espejo A, Galmés J, Medrano H (2008) Mesophyll conductance to $\mathrm{CO}_{2}$ : current knowledge and future prospects. Plant Cell Eviron 31: 602-612

Foyer CH, Descourvières P, Kunert KJ (1994) Protection against oxygen radicals: an important defence mechanism studied in transgenic plants. Plant Cell Environ 17: 507-523 
Frank HA, Bautista JA, Josue JS, Young AJ (2000) Mechanism of nonphotochemical quenching in green plants: energies of the lowest excited singlet states of violaxanthin and zeaxanthin. Biochemistry 39: 2831-2837

Fuerst EP, Norman MA (1991) Interaction of herbicides with photosynthetic electron transport. Weed Sci 39: 458-464

Funk C, Schröder WP, Napiwotzki A, Tjus SE, Renger G, Andersson B (1995) The PSII-S protein of higher plants: a new type of pigmentbinding protein. Biochemistry 34: 11133-11141

Gal A, Shahak Y, Schuster G, Ohad I (1987) Specific loss of LHCII phosphorylation in the Lemna mutant1073 lacking the cytochrome-b6/f complex. FEBS Lett 221: 205-210

Ganeteg U, Strand A, Gustafsson P, Jansson S (2001) The properties of the chlorophyll a/b binding proteins Lhca2 and Lhca3 studied in vivo using antisense inhibition. Plant Physiol 12: 150-158

Gawronski SW, Sugita M, Sugiura M (1992) Mutation of $p s b A$ gene in herbicide- resistant population of Erigeron canadensis. In: Murata N ed. Research in Photosynthesis,Vol III. Kluwer Academic Publi, Dordrecht, pp 405-407

Genty B, Briantais JM, Baker NR (1989) The relationship between the quantum yield of photosynthetic electron-transport and quenching of chlorophyll fluorescence. Biochim Biophys Acta 990: 87-92

Genty B, Goulas Y, Dimon B, Peltier G, Briantais JM, Moya I (1992) Modulation of efficiency of primary conversion in leaves. Photosynth Res 34: 106

Genty B, Harbinson J (1996) Regulation of light utilization for photosynthetic electron transport. In: Baker NR ed. Photosynthesis and the environment. Kluwer Academic Publ, Amsterdam, pp 67-99

Genty B, Meyer S, Piel C, Badeck F, Liozon R (1998) $\mathrm{CO}_{2}$ diffusion inside leaf mesophyll of ligneous plants. In: Garab G ed. Photosynthesis: mechanisms and effects. Kluwer Academic Publ, Dordrecht, pp 3961-3967

Girardi MT, Cona B, Geiken B, Kucera T, Masojidek J, Matoo A K (1996) Longterm drought stress induces structural and functional reorganization of photosystem II. Planta 199: 118-125

Gilmore AM, Yamamoto HY (1992) Dark induction of zeaxanthin dependent nonphotochemical fluorescence quenching mediated by ATP. Proc Natl Acad Sci USA 89: 1899-1903

Golding AJ, Johnson GN (2003) Down-regulation of linear and activation of cyclic electron transport during drought. Planta 218: 107-114

Gollan T, Passioura JB, Munns R (1986) Soil water status affects the stomatal conductance of fully turgid wheat and sunflower leaves. Aust J Plant Physiol 13: 459-464

Gonzales J, Pastenes C, Horton P (2001) Effect of temperature, water and light stresses on PS2 heterogeneity in four bean varieties (Phaseolus vulgaris, L.). Revista Chilena Historia Natural 74: 779791

Goss R, Opitz C, Lepetit B, Wilhelm C (2008) The synthesis of NPQ-effective zeaxanthin depends on the presence of a transmembrane proton gradient and slightly basic stromal side of the thylakoid membrane. Planta 228: 999-1009

Graber P (1987) Primary charge separation and energy transduction in photosynthesis. In: Molazzo G, Blanks M eds. Bioelectrochemistry. Plenum, New York, pp 379-429

Gressel J (1985) Herbicide tolerance and resistance; alteration of site of activity. In: Duke SO ed. Weed Physiology, Vol II. CRC Press, Boca Raton, Florida, pp 159-189

Gressel J, Ben-Sinai G (1985) Low intraspecific competeitive fitness in a triazine-resistant, nearly nuclearisogenic line of Brassica napus. Plant Sci 38: 29-32

Gronwald JW (1994) Resistance to photosystem II inhibiting herbicides. In: Powles SB, Holtum JAM eds. Herbicide Resistance in Plants: Biology and Biochemistry. Lewis Publ, Boca Raton, pp 299-316

Haehnel W (1984). Photosynthetic electron transport in higher plants. Annu Rev Plant Physiol 35: 659-693

Hart JJ, Stemler A (1990) High light-induced reduction and low light-enhanced recovery of photon yield in triazine-resistant Brassica napus. Plant Physiol 94: 1301-1307

Härtel H, Lokstein H (1995) Relationship between quenching of maximum and dark-level chlorophyll fluorescence in vivo: dependence on photosystem II antenna size. Biochim Biophys Acta 1228: 91-94

Härtel H, Lokstein H, Grimm B, Rank B (1996) Kinetic studies on the xanthophyll cycle in barley leaves. Plant Physiol 110: 471-482 
Haupt-Herting S, Fock HP (2002) Oxygen exchange in relation to carbon assimilation in water stressed leaves during photosynthesis. Ann Bot 89: 851-854

Havaux M (1989) Comparison of atrazine-resistant and -susceptible biotypes of Senecio vulgaris L: Effect of high and low temperatures on the in vivo photosynthetic electron transfer in intact leaves. J Exp Bot 40: 849-854

Havaux M, Dall'Osto L, Cuine S, Giuliano G, Bassi R (2004) The effect of zeaxanthin as the only xanthophyll on the structure and function of the photosynthetic apparatus in Arabidopsis thaliana. J Biol Chem 279: 13878-13888

He JX, Wang J, Liang HG (1995) Effects of water-stress on photochemical function and protein-metabolism of photosystem-II in wheat leaves. Physiol Plant 93: 771-777

Heber U, Walker D (1992) Concerning a dual function of coupled cyclic electron transport in leaves. Plant Physiol 100: 1621-1626

Hendrickson L, Furbank RT, Chow WS (2004) A simple alternative approach to assessing the fate of absorbed light energy using chlorophyll fluorescence. Photosynth Res 82: 73-81

Hirschberg J, Bleecker A, Kyle DJ, McIntosh L, Arntzen CJ (1984) The molecular basis of triazineherbicide resistance in higher-plant chloroplasts. Z Naturforsch 39c: $412-420$

Hirschberg J, McIntosh L (1983) The molecular basis of herbicide resistance in Amaranthus hybridus. Science 222: 1346-1349

Holt JS, Stemler AJ, Radosevic SR (1981) Differential light responses of photosynthesis by triazineresistant and triazine-susceptible Senecio vulgaris biotypes. Plant Physiol 67: 744-748

Holt JS, Goffner DP (1985) Leaf structure and function in triazine-resistant common groundsel (Senecio vulgaris). Plant Physiol 79: 699-705

Holt NE, Zigmantas D, Valkunas L, Li XP, Niyogi KK, Fleming GR (2005) Carotenoid cation formation and the regulation of photosynthetic light harvesting. Science 307: 433-436

Horton P (1981) The effect of redox potential on the kinetics of fluorescence induction in peachloroplasts 2. sigmoidicity. Biochim Biophys Acta 637: 152-158

Horton P, Hague A (1988) Studies on the induction of chlorophyll fluorescence in isolated barley protoplasts. IV. Resolution of nonphotochemical quenching. Biochim Biophys Acta 932: 107-115

Horton P, Ruban AV, Rees D, Pascal AA, Noctor G, Young AJ (1991) Control of the light-harvesting function of chloroplast membranes by aggregation of the LHCII chlorophyll-protein complex. FEBS Lett 292: 1-4

Horton P, Ruban AV (1993) Delta-pH-dependent quenching of the Fo-level of chlorophyll fluorescence in spinach leaves. Biochim Biophys Acta 1142: 203-206

Horton P, Ruban AV, Walters RG (1994) Regulation of light harvesting in green plants: indication by nonphotochemical quenching of chlorophyll fluorescence. Plant Physiol 106: 415-420

Horton P, Ruban AV, Walters RG (1996) Regulation of light harvesting in green plants. Annu Rev Plant Physiol Plant Mol Biol 47: 665-684

Horton P, Ruban AV, Wentworth M (2000) Allosteric regulation of the light harvesting system of photosystem II. Philos Trans R Soc Lond B Biol Sci 355: 1361-1370

Horton P, Wentworth M, Ruban A (2005) Control of the light harvesting function of chloroplast membranes: The LHCII-aggregation model for non-photochemical quenching. FEBS Lett 579: 42014206

Horton P, Johnson MP, Pérez-Bueno M, Kiss AZ, Ruban AV (2008) Does the structure and macroorganization of photosystem II in higher plant grana membranes regulate light harvesting states? FEBS J 275: 1069-1079

Hurry V, Anderson JM, Badger MR, Price GD (1996) Reduced levels of cytochrome $b 6 / f$ in transgenic tobacco increases the excitation pressure on photosystem II without increasing the sensitivity to photoinhibition in vivo. Photosynth Res 50: 159-69

Ilioaia C, Johnson M, Horton P, Ruban AV (2008) Induction of efficient energy dissipation in the isolated light harvesting complex of photosystem II in the absence of protein aggregation. J Biol Chem 283: 29505-29512

Ireland CR, Telfer A, Covello PS, Baker NR, Barber J (1988) Studies on the limitations to photosynthesis in leaves of the herbicide-resistant mutant of Senecio vulgaris L. Planta 173: 459-467 
Ivanov AG, Sane PV, Hurry V, Öquist G, Huner NPA (2008) Photosystem II reaction centre quenching: mechanisms and physiological role. Photosynth Res 98: 565-574

Jansson S (1999) A guide to the Lhc genes and their relatives in Arabidopsis. Trends Plant Sci 4: 236-240

Johnson MP, Pérez-Bueno ML, Zia A, Horton P, Ruban AV (2009) The zeaxanthin-independent and zeaxanthin-dependent $\mathrm{qE}$ components of nonphotochemical quenching involve common conformational changes within the photosystem II antenna in Arabidopsis. Plant Physiol 149: 1061-1075

Johnson MP, Ruban AV (2010) Arabidopsis plants lacking PsbS protein possess photoprotective energy dissipation. Plant J 61: 283-289

Jung HS, Niyogi KK (2009) Quantitative genetic analysis of thermal dissipation in Arabidopsis. Plant Physiol 150: 997-986

Kalituho L, Grasses T, Graf M, Rech J, Jahns P (2006) Characterization of a nonphotochemical quenchingdeficient Arabidopsis mutant possessing an intact PsbS protein, xanthophyll cycle and lumen acidification. Planta 223: 532-541

Kato MC, Hikosaka K, Hirotsu N, Makino A, Hirose T (2003) The excess light energy that is neither utilized in photosynthesis nor dissipated by photoprotective mechanisms determines the rate of photoinactivation in photosystem II. Plant Cell Physiol 44: 318-325

Kiss A, Ruban AV, Horton P (2008) The PsbS protein controls the organization of the photosystem II antenna in higher plant thylakoid membranes. J Biol Chem 283: 3972-3978

Kloppstech K (1997) Light regulation of photosynthetic genes. Physiol Plant 100: 739-747

Klughammer C, Schreiber U (2008) Complementary PS II quantum yields calculated from simple fluorescence parameters measured by PAM fluorometry and the saturation pulse method. PAM Application Notes 1: 27-35

Kohno H, Ohki A, Ohki S, Koizumi K, Van den Noort ME, Rodrigues GC, van Rensen JJ, Wakabayashi K (2000) Low resistance against novel benzylamino-1,3,5-triazine herbicides in atrazine-resistant Chenopodium album plants. Photosynth Res 65: 115-120

Kovács L, Damkjær J, Kereïche S, Ilioaia C, Ruban AV, Boekema EJ, Jansson S, Horton P (2006) Lack of the light-harvesting complex CP24 affects the structure and function of the grana membranes of higher plant chloroplasts. Plant Cell 18: 3106-3120

Krause GH (1988) Photoinhibiton of photosynthesis: an evaluation of damaging and protective mechanisms. Physiol Plant 74: 566-574

Krivosheeva A, Tao DL, Ottander C, Wingsle G, Dube SL, Öquist G (1996) Cold acclimation and photoinhibition of photosynthesis in Scots pine. Planta 200: 296-305

Kuiper PJC (1980) Lipid metabolism as a factor in environmental adaptation. In: Mazliak P, Benveniste P, Costes C, Douce R eds. Biogenesis and function of plant lipids. Elsevier, Amsterdam, pp 169-176

Külheim C, Ågren J, Jansson S (2002) Rapid regulation of light harvesting and plant fitness in the field. Science 297: 91-93

Kyle DJ (1987) The biochemical basis for photoinhibition of photosystem II. In: Kyle DJ, Osmond CB, Arntzen CJ eds. Photoinhibition. Elsevier, Amsterdam, pp 197-226

Laemmli UK (1970) Cleavage of structural proteins during the assembly of the head of bacteriophage T4. Nature 227: 680-685

Lambrev PH, Nilkens M, Miloslavina Y, Jahns P, Holzwarth AR (2010) Kinetic and spectral resolution of multiple nonphotochemical quenching components in Arabidopsis leaves. Plant Physiol 152: 16111624

Lawlor DW (2002) Limitations to Photosynthesis in water-stressed leaves: stomatal vs. metabolism and the role of ATP. Ann Bot 89: 871-885

Lawlor DW, Cornic G (2002) Photosynthetic carbon assimilation and associated metabolism in relation to water deficits in higher plants. Plant Cell Environ 25: 275-294

Lehoczki E, Pölös E, Laskay G, Farkas T (1985) Chemical compositions and physical states of chloroplast lipids related to atrazine resistance in Conyza canadensis. Plant Sci 42: 19-24

Lemoine Y, Dubacq JP, Zabulon G, Ducruet JM (1986) Organization of the photosynthetic apparatus from triazine-resistant and -susceptible biotypes of several plant species. Can J Bot 64: 2999-3007

Li XP, Björkman O, Shih C, Grossman AR, Rosenquist M, Jansson S, Niyogi KK (2000) A pigmentbinding protein essential for regulation of photosynthetic light harvesting. Nature 403: 391-395 
Li XP, Phippard A, Pasari J, Niyogi KK (2002a) Structure-function analysis of photosystem II subunit S (PsbS) in vivo. Funct Plant Biol 29: 1131-1139

Li XP, Muller-Moule P, Gilmore AM, Niyogi KK (2002b) PsbS-dependent enhancement of feedback deexcitation protects photosystem II from photoinhibition. Proc Natl Acad Sci USA 99: 15222-15227

Li XP, Gilmore AM, Caffarri S, Bassi R, Golan T, Kramer D, Niyogi KK (2004) Regulation of photosynthetic light harvesting involves intrathylakoid lumen $\mathrm{pH}$ sensing by the PsbS protein. J Biol Chem 279: 22866-22874

Li Z, Ahn TK, Avenson TJ, Ballotari M, Cruz JA, Kramer DM, Bassi R, Fleming GR, Keasling JD, Niyogi KK (2009) Lutein accumulation in the absence of zeaxanthin restores nonphotochemical quenching in the Arabidopsis thaliana npq1 mutant. Plant Cell 21: 1798-1812

Lichtenthaler HK (1987) Chlorophylls and carotenoids: Pigments of photosynthetic Biomembranes. In: Packer L, Douce R eds. Methods in Enzymology. Academic Press, New York, 148: 350-382

Liu ZF, Yan HC, Wang KB, Kuang TY, Zhang JP, Gui LL, An XM, Chang WR (2004) Crystal structure of spinach major-light harvesting complex at 2.72 resolution. Nature 428: 287-292

Lokstein H, Tian L, Polle JEW, DellaPenna D (2002) Xanthophyll biosynthetic mutants of Arabidopsis thaliana: altered nonphotochemical quenching of chlorophyll fluorescence is due to changes in photosystem II antenna size and stability. Biochim Biophys Acta 1553: 309-319

Long SP, Humphries S, Falkowski PG (1994) Photoinhibition of photosynthesis in nature. Plant Physiol Plant Mol Biol 45: 633-662

Matsubara S, Gilmore AM, Osmond CB (2001) Diurnal and acclimatory responses of violaxanthin and lutein epoxide in the Australian mistletoe Amyema miquelii. Aust J Plant Physiol 28: 793-800

McCloskey WB, Holt JS (1990) Triazine resistance in Senecio vulgaris parental and nearly isonuclear backcrossed biotypes is correlated with reduced productivity. Plant Physiol 92: 954-962

Melis A (1985) Functional properties of PS II $\beta$ in spinach chloroplasts. Biochim Biophys Acta 808: 334342

Melis A (1991) Dynamics of photosynthetic membrane-composition and function. Biochim Biophys Acta 1058: 187-106

Meyer S, Genty B (1998) Mapping intercellular $\mathrm{CO}_{2}$ mole fraction (Ci) in Rosa rubiginosa leaves fed with abscisic acid by using chlorophyll fluorescence imaging: significance of $\mathrm{Ci}$ estimated from leaf gas exchange. Plant Physiol 116: 947-957

Miloslavina Y, Wehner A, Wientjes E, Reus M, Lambrev P, Garab G, Croce R, Holzwarth AR (2008) Farred fluorescence: a direct spectroscopic marker for LHCII oligomers forming in non photochemical quenching. FEBS Lett 582: 3625-3631

Miyake C, Shinzaki Y, Miyata M, Tomizawa K (2004) Enhancement of cyclic electron flow around PSI at high light and its contribution to the induction of non-photochemical quenching of chl fluorescence in intact leaves of tobacco plants. $45: 1426-1433$

Mozzo M, Passarini F, Bassi R, van Amerongen H, Croce R (2008) Photoprotection in higher plants: the putative quenching site is conserved in all outer light-harvesting complexes of photosystem II. Biochim Biophys Acta 1777: 1263-1267

Mullet JE (1983) The amino-acid-sequence of the polypeptide segment which regulates membrane adhesion (grana stacking) in chloroplasts. J Biol Chem 258: 9941-9948

Mullineaux CW, Ruban AV, Horton P (1994) Prompt heat release associated with delta-pH dependent quenching in spinach thylakoid membranes. Biochim Biophys Acta 1185: 119-123

Munekage Y, Hashimoto M, Miyake C, Tomizawa K, Endo T, Tasaka M, Shikanai T (2004) Cyclic electron flow around photosystem I is essential for photosynthesis. 429: 579-582

Murata N, Takahashi S, Nishiyama Y, Allakhverdiev SI (2007) Photoinhibition of photosystem II under environmental stress. Biochim Biophys Acta 1767: 414-421

Niyogi KK, Björkman O, Grossman AR (1997) Chlamydomonas xanthophyll cycle mutants identified by video imaging of chlorophyll fluorescence quenching. Plant Cell 9: 1369-1380

Niyogi KK, Grossman AR, Björkman O (1998) Arabidopsis mutants define a central role for the xanthophyll cycle in the regulation of photosynthetic energy conversion. Plant Cell 10: 1121-1134

Niyogi KK (1999) Photoprotection revisited: Genetic and molecular approaches. Annu Rev Plant Physiol Plant Mol Biol 50: 333-359 
Niyogi KK (2000) Safety valves for photosynthesis. Curr Opin Plant Biol 3: 455-460

Niyogi KK, Shih C, Chow SW, Pogson BJ, DellaPenna D, Börkman O (2001) Photoprotection in a zeaxanthin- and lutein-deficient double mutant of Arabidopsis. Photosynth Res 67: 139-145

Niyogi KK, Li XP, Rosenberg V, Jung HS (2005) Is PsbS the site of nonphotochemical quenching in photosynthesis? J Exp Bot 56: 375-382

Noctor G, Ruban AV, Horton P (1993) Modulation of delta-pH-dependent nonphotochemical quenching of chlorophyll fluorescence in spinach-chloroplasts. Biochim Biophys Acta 1183: 339-344

Noctor G, Veljovic-Jovanovic S, Driscoll S, Novitskaya L, Foyer CH (2002) Drought and oxidative load in the leaves of C-3 plants: a predominant role for photorespiration? Ann Bot 89: 841-850

Ort DR, Ahrens WH, Martin B, Stoller EW (1983) Comparison of photosynthetic performance in triazineresistant and susceptible biotypes of Amaranthus hybridus. Plant Physiol 72: 925-930

Ort DR (2001) When there is too much light. Plant Physiol 125: 29-32

Osmond CB, Grace SC (1995) Perspectives on photoinhibition and photorespiration in the field: quintessential inefficiencies of the light and dark reactions of photosynthesis? J Exp Bot 46: 1351-1362

Oxborough K, Horton P (1988) A study of the regulation and function of energy-dependent quenching in pea-chloroplasts. Biochim Biophys Acta 934: 135-143

Ögren E, Öquist G (1985) Effects of drought on photosynthesis, chlorophyll fluorescence and photoinhibition susceptibility in intact willow leaves. Planta 166: 380-388

Ögren E, Sjöström M (1990) Estimation of the effect of photoinhibition on the carbon gain in leaves of a willow canopy. Planta 181: 560-567

Ögren E, Rosenqvist E (1992) On the significance of photoinhibition of photosynthesis in the field and its generality among species. Photosynth Res 33: 63-71

Parry MAJ, Andralojc PJ, Khan S, Lea PJ, Keys AJ (2002) Rubisco activity: effects of drought stress. Ann Bot 89: 833-839

Peterson RB, Havir EA (2000) A nonphotochemical-quenching-deficient mutant of Arabidopsis thaliana possessing normal pigment composition and xanthophyll-cycle activity. Planta 210: 205-214

Pfister K, Arntzen CJ (1979) The mode of action of photosystem II-specific inhibitors in herbicide-resistant weed biotypes. Z Naturforsch 34c: 996-1009

Pfündel E, Renganathan M, Gilmore AM, Yamamoto HY, Dilley RA (1994) Intrathylakoid pH in isolated pea chloroplasts as probed by violaxanthin de-epoxidation. Plant Physiol 106: 1647-1658

Polle A (1997) Defense against photooxidative damage in plants. In: Scandalios JG ed. Oxidative Stress and the Molecular Biology of Antioxidant Defenses. Cold Spring Harbor Lab Press, Plainview, NY, pp 623666

Pogson BJ, Niyogi KK, Björkman O, DellaPenna D (1998) Altered xanthophyll compositions adversely affect chlorophyll accumulation and non-photochemical quenching in Arabidopsis mutants. Proc Natl Acad Sci USA 95: 13324-13329

Pogson BJ, Rissler HM (2000) Genetic manipulation of carotenoid biosynthesis and photoprotection. Philos Trans R Soc Lond B Biol Sci 355: 1395-1403

Powles SB, Björkman O (1982) Photoinhibition of photosynthesis: effect on chlorophyll fluorescence at $77 \mathrm{~K}$ in intact leaves and in chloroplast membranes of Nerium oleander. Planta 156: 97-107

Quick WP, Stitt M (1989) An examination of factors contributing to nonphotochemical quenching of chlorophyll fluorescence in barley leaves. Biochim Biophys Acta 977: 287-296

Renou JL, Gerbaud A, Just D, André M (1990) Differing substomatal and chloroplastic $\mathrm{CO}_{2}$ concentrations in water-stressed wheat. Planta 183: 415-419

Riera M, Valon C, Fenzi F, Giraduat J, Leung J (2005) The genetics of adaptive responses to drought stress: abscisic acid-dependent and abscisic acid-independent signalling comonents. Physiol Plant 123: 111119

Ruban AV, Rees D, Noctor GD, Young A, Horton P (1991) Long-wavelength chlorophyll species are associated with amplification of high-energy-state excitation quenching in higher-plants. Biochim Biophys Acta 1059: 355-360

Ruban AV, Horton P, Young AJ (1993a) Aggregation of high plant xanthophylls: differences in absorption spectra and in the dependency on solvent polarity. J Photochem Photobiol B Biol 21: 229-234 
Ruban AV, Young AJ, Horton P (1993b) Induction of non-photochemical quenching and absorbance changes in leaves. Plant Physiol 102: 741-750

Ruban AV, Young AJ, Horton P (1994) Modulation of chlorophyll fluorescence quenching in isolated lightharvesting complex of photosystem-II. Biochim Biophys Acta 1186: 123-127

Ruban AV, Horton P (1995) Regulation of nonphotochemical quenching of chlorophyll fluorescence in plants. Aust J Plant Physiol 22: 221-230

Ruban AV, Young AJ, Horton P (1996) Dynamic properties of the minor chlorophyll a/b binding proteins of higher plants: an in vitro model for photoprotective nonphotochemical energy dissipation. Biochemistry 35: 674-678

Ruban AV, Horton P (1999) The xanthophyll cycle modulates the kinetics of non-photochemical energy dissipation in isolated light-harvesting complexes, intact chloroplasts and leaves of spinach. Plant Physiol 119: 531-542

Ruban AV, Lee PJ, Wentworth M, Young AJ, Horton P (1999) Determination of the stoichiometry and strength of binding of xanthophylls to the PSII light harvesting complexes. J Biol Chem 274: 1045810465

Ruban AV, Pascal AA, Lee PJ, Robert B, Horton P (2002a) Molecular configuration of xanthophyll cycle carotenoids in photosystem II antenna complexes. J Biol Chem 277: 42937-42942

Ruban AV, Pascal AA, Robert B, Horton P (2002b) Activation of zeaxanthin is an obligatory event in the regulation of photosynthetic light harvesting. J Biol Chem 277: 7785-7789

Ruban AV, Wentworth M, Yakushevska AE, Andersson J, Lee PJ, Keegstra W, Dekkerk JP, Boekema EJ, Jansson S, Horton P (2003) Plants lacking the main light-harvesting complex retain photosystem II macro-organization. Nature 421: 648-653

Ruban AV, Berera R, Ilioaia C, van Stokkum IHM, Kennis JTM, Pascal AA, van Amerongen H, Robert B, Horton P, van Grondelle R (2007) Identification of a mechanism of photoprotective energy dissipation in higher plants. Nature 450: 575-578

Sahsah Y, Campos P, Gareil M, Zuily-Fodil A, Pham-Thi T (1998) Enzymatic degradation of polar lipids in Vigna unguiculata leaves and influence of drought stress. Physiol Plant 104: 577-586

Schansker G, van Rensen JJS (1999) Performance of active photosystem II centers in photoinhibited pea leaves. Photosynth Res 62: 175-184

Schansker G, Tóth SZ, Strasser RJ (2006) Dark recovery of the Chl $a$ fluorescence transient (OJIP) after light adaptation: The $\mathrm{q} T$-component of non-photochemical quenching is related to an activated photosystem I acceptor side. Biochim Biophys Acta 1757: 787-797

Schindler C, Lichtenthaler HK (1994) Is there a correlation between light-induced zeaxanthin accumulation and quenching of variable chlorophyll $a$ fluorescence? Plant Physiol Biochem 32: 813-823

Schönfeld M, Yaacoby T, Michael O, Rubin B (1987) Triazine resistance without reduced vigor in Phalaris paradoxa. Plant Physiol 83: 329-333

Schreiber U (1986) Detection of rapid induction kinetics with a new type of high-frequency modulated chlorophyll fluorometer. Photosynth Res 9: 261-272

Schreiber U, Bilger W, Neubauer C (1994) Chlorophyll fluorescence as a non-intrusive indicator for rapid assessment of in vivo photosynthesis. In: Schulze ED, Caldwell MM eds. Ecophysiology of Photosynthesis. Springer-Verlag, Berlin, pp 49-70

Schulze ED (1986) Whole-plant responses to drought. Aust J Plant Physiol 13: 127-141

Somersalo S, Krause GH (1988) Changes in chlorophyll fluorescence related to photoinhibition of photosynthesis and cold acclimation of green plants. In: Lichtenthaler HK ed. Applications of Chlorophyll Fluorescence. Kluwer Academic Publ, Dordrecht, pp 157-164

Souza Machado V, Bandeen JD, Stephenson GR, Lavigne P (1978) Uniparental inheritance of chloroplast atrazine tolerance in Brassica campestris. Can J Plant Sci 58: 977-981

Srivastava A, Strasser RJ, Govindjee (1995) Polyphasic rise of chlorophyll $a$ fluorescence in herbicideresistant D1 mutants of Chlamydomonas reinhardtii. Photosynth Res 43: 131-141

Stowe AE, Holt JS (1988) Comparison of triazine-resistant and -susceptible biotypes of Senecio vulgaris and their F1 hybrids. Plant Physiol 87: 183-189 
Strasser RJ, Srivastava A, Tsimilli-Michael M (2000) The fluorescence transient as a tool to characterize and screen photosynthetic samples. In: Mohanty P, Yunus M, Pathre U eds. Probing Photosynthesis Mechanism, Regulation and Adaptation. Taylor and Francis, London, pp 445-480

Strasser RJ, Tsimilli-Michael M, Srivastava A (2004) Analysis of the chlorophyll a fluorescence transient. In: Papageorgiou GC, Govindjee, eds. Chlorophyll fluorescence: a signature of photosynthesis. Advances in photosynthesis and respiration series, Vol 19. Kluwer Academic Publ, Rotterdam, pp 321362

Sundblad LG, Schröder WP, Akerlung HE (1988) S-state distribution and redox state of $\mathrm{Q}_{\mathrm{A}}$ in barley in relation to luminescence decay kinetics. Biochim Biophys Acta 973: 47-52

Sundby C, Chow WS, Anderson JM (1993a) Effects on photosystem II function, photoinhibition, and plant performance of the spontaneous mutation of Serine-264 in the photosystem II reaction center D1 protein in triazine-resistant Brassica napus L. Plant Physiol 103: 105-113

Sundby C, McCaffery S, Chow WS, Anderson JM (1993b) Photosystem II function, photoinhibition and turnover of the D1 protein at different irradiances in normal and atrazine-resistant plants with an altered $\mathrm{Q}_{\mathrm{B}}$-binding site In: Murata $\mathrm{N}$ ed. Research in photosynthesis, Vol IV. Kluwer Academic Publ, Dordrecht, pp 443-447

Suss KH, Yordanov I (1986) Biosynthetic cause of in vivo acquired thermotolerance of photosynthetic light reactions and metabolic responses of chloroplasts to heat stress. Plant Physiol 81: 192-199

Szigeti Z, Lehoczki E (2003) A review of physiological and biochemical aspects of resistance to atrazine and paraquat in Hungarian weeds. Pest Manag Sci 59: 451-458

Tambussi EA, Casadesus J, Munné-Bosch S, Araus JL (2002) Photoprotection in water-stressed plants of durum wheat (Triticum turgidum var. durum): Changes in chlorophyll fluorescence, spectral signature and photosynthetic pigments. Funct Plant Biol 29: 35-44

Teardo E, Polverino de Laureto P, Bergantino E, Dalla Vecchia F, Rigoni F, Szabó I, Giacometti GM (2007) Evidences for interaction of PsbS with photosynthetic complexes in maize thylakoids. Biochim Biophys Acta 1767: 703-711

Tenhunen JD, Lange OL, Gebel J, Beyschlag W, Weber JA (1984) Changes in photosynthetic capacity, carboxylation efficiency, and $\mathrm{CO}_{2}$ compensation point associated with midday stomatal closure and midday depression of net $\mathrm{CO}_{2}$ exchange of leaves of Quercus suber. Planta 162: 193-203

Tezara W, Mitchell VJ, Driscoll SD, Lawlor DW (1999) Water stress inhibits plant photosynthesis by decreasing coupling factor and ATP. Nature 401: 914-917

Tezara W, Mitchell VJ, Driscoll SD, Lawlor DW (2002) Effects of water deficit and its interactions with $\mathrm{CO}_{2}$ supply on the biochemistry and physiology of photosynthesis in sunflower. J Exp Bot 53: 17811791

Thiele A, Winter K, Krause GH (1997) Low inactivation of D1 protein of photosystem II in young canopy leaves of Anacardium excelsum under high-light. J Plant Physiol 151: 286-292

Thimmanaik S, Giridara Kumar S, Jyothsna Kumari G, Suryanarayana N, Sudhakar C (2002) Photosynthesis and the enzymes of photosynthetic carbon reduction cycle in mulberry during water stress and recovery. Photosynthetica 40: 233-236

Tian X, Darmency H (2006) Rapid bidirectional allele-specific PCR identification for triazine resistance in higher plants. Pest Manag Sci 62: 531-536

Tourneux C, Peltier G (1995) Effect of water deficit on photosynthetic oxygen exchange measured using ${ }^{18} \mathrm{O}_{2}$ and mass spectrometry in Solanum tuberosum L. leaf discs. Planta 195: 570-577

Trebst A (1991) The molecular basis of resistance of photosystem II herbicides. In: Caseley JC, Cussans GW, Atkin RK eds. Herbicide Resistance in Weeds and Crops. Butterwort-Heinemann, Oxford, pp 145164

Tsimilli-Michael M, Strasser RJ (2008) In vivo assessment of stress impact on plant's vitality: applications in detecting and evaluating the beneficial role of mycorrhization on host plants. In: Varma A ed. Mycorrhiza: Genetics and Molecular Biology, Eco-function, Biotechnology, Eco-physiology, and Structure and Systematics. Springer-Verlag, Berlin, Heidelberg, pp 679-703

van Kooten O, Snel JFH (1990) The use of chlorophyll fluorescence nomenclature in plant stress physiology. Photosynth Res 25: 147-150 
van Oorschot JLP, Leeuwen PH (1989) Photosynthetic capacity of intact leaves of resistant and susceptible cultivars of Brassica napus L. to atrazine. Weed Res 29: 29-32

van Rensen JJS, Rodrigues GC, Vredenberg WJ (2001) Analysis of electron flow around photosystem II in atrazine-resistant plants applying the three-state trapping model on the fluorescence induction curve. In: Proceedings 12. International Congress on Photosynthesis, Brisbane, Australia, S14-007

Váradi Gy, Darkó É, Pölös E, Szigeti Z, Lehoczki E (1994) Xanthophyll cycle patterns and in vivo photoinhibition in herbicide-resistant biotypes of Conyza canadensis. J Plant Physiol 144: 669-674

Váradi Gy, Polyánka H, Darkó É, Lehoczki E (2003) Atrazine resistance entails a limited xanthophyll cycle activity, a lower PS II efficiency and an altered pattern of excess excitation dissipation. Physiol Plant 118: $47-56$

Velthuys BR (1981) Electron dependent competition between plastoquinone and inhibitorsfor binding to photosystem II. FEBS Lett 126: 277-281

von Caemmerer S, Farquhar GD (1981) Some relationships between the biochemistry of photosynthesis and the gas exchange of leaves. Planta 153: 376-387

von Caemmerer S (2000) Techniques in Plant Sciences Vol 2: Biochemical Models of Leaf Photosynthesis. CSIRO Publishing, Collingwood

Walters RG, Horton P (1991) Resolution of components of non-photochemical chlorophyll fluorescence quenching in barley leaves. Photosynth Res 27: 121-133

Walters RG, Horton P (1993) Theroetical assesment of alternative mechanisms for non-photochemical chlorophyll quenching in barley leaves. Photosynth Res 36: 741-750

Walters RG, Ruban AV, Horton P (1994) Higher plant light-harvesting complexes LHCIIa and LHCIIc are bound by dicyclohexylcarbodiimide during inhibition of energy dissipation. Eur J Biochem 226: 10631069

Walters RG, Ruban AV, Horton P (1996) Identification of proton-active residues in a higher plant lightharvesting complex. Proc Natl Acad Sci USA 93: 14204-14209

Weiss E, Berry JA (1987) Quantum efficiency of pPhotosystem-II in relation to energy-dependent quenching of chlorophyll fluorescence. Biochim Biophys Acta 894: 198-208

Vermaas WFJ, Arntzen CJ,. Gu LQ, Yu C-A (1983) Interactions of herbicides and azidoquinones at a photosystem II binding site in the thylakoid membrane. Biochim Biophys Acta 723: 266-275

Whitmarsh J, Samson G, Poulson M (1994) Photoprotection in photosystem II - the role of cytochrome $b_{559}$. In: Baker NR, Bowyer JR eds. Photoinhibition of Photosynthesis: From Molecular Mechanisms to the Field. BIOS Sci Publ, Oxford, pp 75-93

Wraight CA, Crofts AR (1970) Energy-dependent quenching of chlorophyll a fluorescence in isolated chloroplasts. Eur J Biochem 17: 319-327

Yordanov I, Tsonev T, Goltsev V, Merakchiiska-Nikolova M, Georgieva K (1997) Gas exchange and chlorophyll fluorescence during water and high temperature stresses and recovery. Probable protective effect of carbamide cytokinin 4-PU30. Photosynthetica 33: 423-431

Zhang JX, Nguyen HT, Bluma A (1999) Genetic analysis of osmotic adjustment in crop plants. J Exp Bot 50: $291-302$ 


\section{FÜGGELÉK}
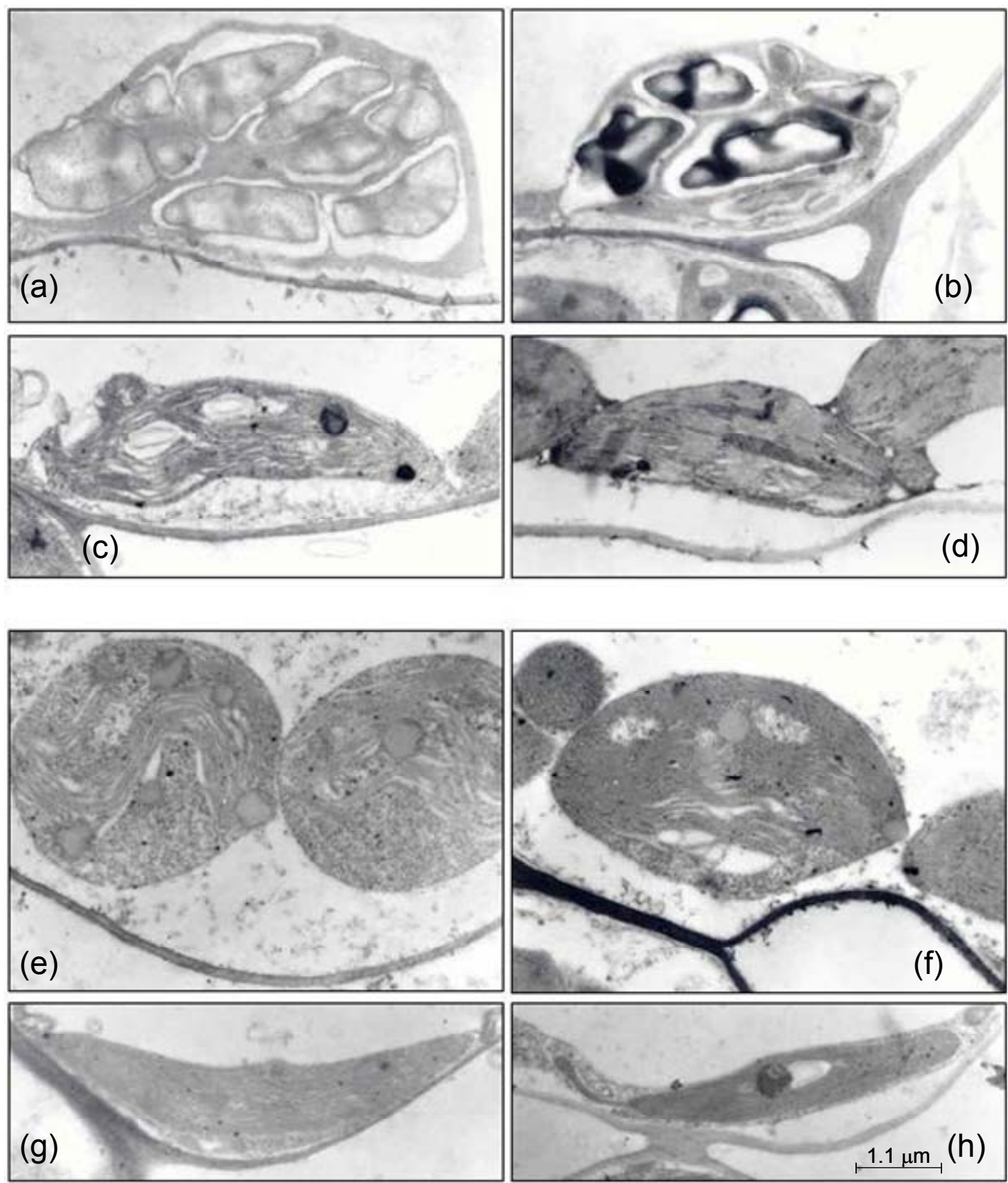

1. ábra $A$ vizdeficit hatása a kloroplasztiszok szerkezetére $S$. nigrum $A S(a, c, e, g)$ és $A R$ biotípusaiban $(b, d, f, h)$. Jó vízellátottságú kontroll, a és b; közepes vízhiány (DH2), c és $d$; erös vízhiány (DH3), e és f; rehidratált a DH3 állapotból, g és $h$. 
(a)

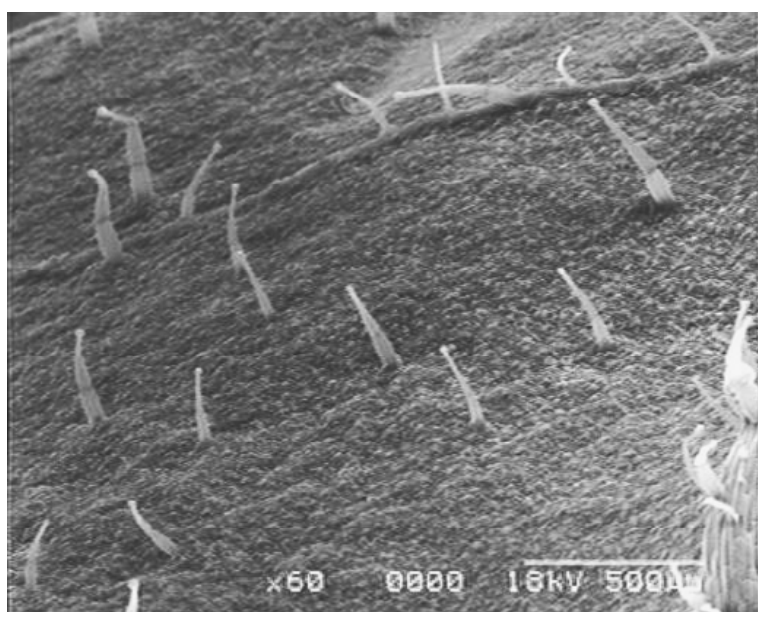

(b)

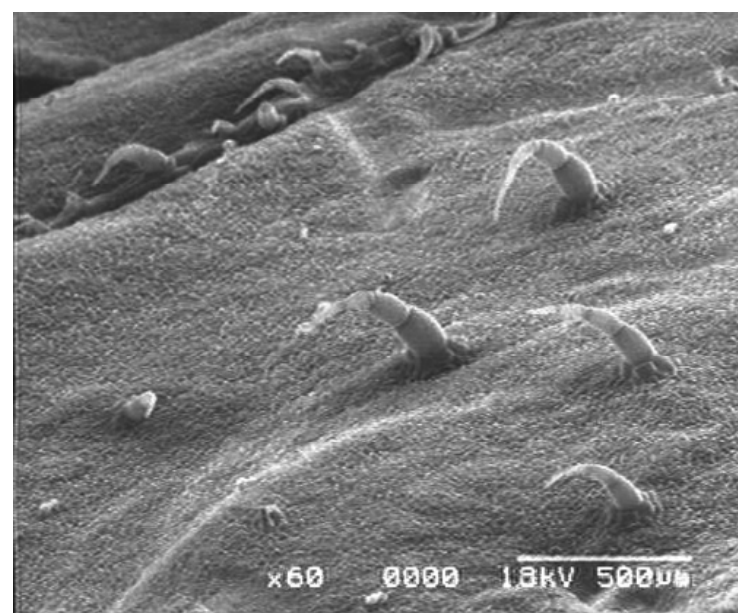

2. ábra Trichómák vizsgálata $A S$ (a) és AR (b) biotípusú S. nigrum növények abaxiális levélfelületein Scanning Elektron Mikroszkópiával (60 × nagyitás). 


\section{Publikációs lista}

Tari I, Csiszár J, Gallé Á, Bajkán Sz, Szepesi Á, Vashegyi Á (2004) Élettani megközelítések gazdasági növények szárazságtürésének genetikai transzformációval történő javítására. Bot Közl 90: $139-158$

*Bajkán Sz, Váradi Gy, Balogh M, Domonkos Á, Kiss GyB, Kovács L, Lehoczki E (2010) Conserved structure of the chloroplast-DNA encoded D1 protein is essential for effective photoprotection via non-photochemical thermal dissipation in higher plants. Mol Genet Genomics 284: 55-63

IF: $\mathbf{2 , 8 5 3}$

*Bajkán Sz, Várkonyi Zs, Lehoczki E (2011) Comparative study on energy partitioning in photosystem II of two Arabidopsis thaliana mutants with reduced non-photochemical quenching capacity. Acta Physiol Plant (közlésre elfogadva)

IF: 1,232

Lehotai N, Pető A, Bajkán Sz, Erdei L, Tari I, Kolbert Zs (2011) In vivo and in situ visualization of early physiological events induced by heavy metals in pea root meristem. Acta Physiol Plant, DOI 10.1007/s11738-011-0759-Z

IF: 1,232

Konferencia közlemények:

Tari I, Simon LM, Deér KA, Csiszár J, Bajkán Sz, Kis Gy, Szepesi Á (2004) Influence of salicylic acid on salt stress acclimation of tomato plants: oxidative stress responses and osmotic adaptation. (poster) The 14th FESPB Congress, August 23-27, 2004, Cracow, Poland, Acta Physiol Plant, Book of Abstracts, pp. 237

IF: $\mathbf{0 , 4 3 3}$

Csiszár J, Tari I, Szepesi Á, Gallé Á, Bartha B, Bajkán Sz, Zeller D, Vashegyi Á, Pécsváradi A, Horváth F, Lazar A, Camen D, Staicu M, Petolescu (Dragoescu) C, Gabor L, Erdei L (2004) Oxidative stress and total antioxidants as estimated by using ferric reducing antioxidant power (FRAP) assays in vegetable genotypes. (oral presentation) PHARE Conference, 3-5 September, 2004, Timisoara

Csiszár J, Tari I, Szepesi Á, Gallé Á, Bartha B, Bajkán Sz, Zeller D, Vashegyi Á, Pécsváradi A, Horváth F, Lazar A, Dorin C, Staicu M, Petolescu C, Gabor L, Erdei L (2004). Az antioxidáns védőmechanizmus egyes elemeinek vizsgálata zöldségfélékben szárazságstressz hatására. Zárójelentés, 37-43. old., Magyarország - Románia PHARE CBC Program (projekt szám: HU 2002/000, 627, 03-14), Román-magyar miniszimpózium

*Bajkán Sz, Váradi Gy, Lehoczki E (2005) The response of photosynthesis to water deficit in atrazine-susceptible and resistant biotypes of Solanum nigrum. (oral presentation) The 8th Hungarian Congress on Plant Physiology, The 6th Hungarian Conference on Photosynthesis, August 25-28, 2005, Szeged, Hungary, Acta Biol Szeged 49: 203-205 
*Bajkán Sz, Váradi Gy, Lehoczki E (2005) Chlorophyll fluorescence quenching analysis of Solanum nigrum in relation to water deficit. (poster) The 8th Hungarian Congress on Plant Physiology, The 6th Hungarian Conference on Photosynthesis, August 25-28, 2005, Szeged, Hungary, Acta Biol Szeged 49: 207-209

*Várkonyi Zs, Bajkán Sz, Váradi Gy, Lehoczki E (2005) Light response of the chlorophyll fluorescence parameters and partitioning of absorbed light energy in wild type and npq4 mutant of Arabidopsis thaliana. (poster) The 8th Hungarian Congress on Plant Physiology, The 6th Hungarian Conference on Photosynthesis, August 25-28, 2005, Szeged, Hungary, Acta Biol Szeged 49: 229-232

Szepesi Á, Csiszár J, Bajkán Sz, Gémes K, Horváth F, Erdei L, Deér KA, Simon LM, Tari I (2005) (poster) Role of salicylic acid pre-treatment on the acclimation of tomato plants to salt and osmotic stress. The 8th Hungarian Congress on Plant Physiology, The 6th Hungarian Conference on Photosynthesis, August 25-28, 2005, Szeged, Hungary Acta Biol Szeged 49: 123-125

Tari I, Szepesi Á, Csiszár J, Bajkán Sz, Gémes K, Horváth F, Erdei L, Deér A, Simon LM (2005) Role of salicylic acid pre-treatment on the acclimation of tomato plants to salt stress. (oral presentation) The 8th Hungarian Congress on Plant Physiology, 6th Hungarian Conference on Photosynthesis, August 22-25, 2005, Szeged, Hungary

Bajkán Sz, Tóth T, Holzwarth AR, Garab Gy, Kovács L (2008) Light-induced conformational changes in the reaction center of photosystem II, revealed by fluorescence measurements. (poster) The 9th Congress of Hungarian Society on Plant Biology, June 7-9, 2008, Szeged, Hungary

Tóth T, Bajkán Sz, Garab Gy, Kovács L (2008) The role of LHCII in the macro-organization of thylakoid membranes. (poster) The 9th Congress of Hungarian Society on Plant Biology, June 7-9, 2008, Szeged, Hungary

* A dolgozatban felhasznált közlemények 


\section{KöSZÖNETNYILVÁNÍTÁS}

Ezúton szeretném megköszönni témavezetőmnek, Lehoczki Endre Tanár Úrnak mind szakmai, mind emberi támogatását és az együtt töltött három évet.

Köszönettel tartozom az MTA SZBK Növénybiológiai Intézet munkatársainak, Kovács Lászlónak, a dolgozatom elkészítésében nyújtott szakmai segítségéért és a Western blot analízis kivitelezéseért; köszönettel tartozom Tóth Szilviának, a gyors klorofill fluoreszcencia mérésekben nyújtott segítségéért, és a TEM vizsgálatok esetében Mustárdy Lászlónak; megköszönöm Ughy Bettinának és Várkonyi Zsuzsannának a kísérleteim elvégzéséhez nyújtott értékes segítségét és baráti támogatásukat. Köszönet illeti az MBK Genetikai

Intézetének munkatársait, Domonkos Ágotát, Balogh Mártát és Kiss György Botondot, a szekvenálási munkáért. Köszönettel tartozom a Corvinus Egyetem Szőlészeti és Borászati Kutatóintézet tagjainak, Váradi Gyulának, a pigmentösszetétel mérésekben nyújtott segítségéért, müszerek használatának biztosításáért és a dolgozatom revíziójáért, és Szegedi Ernőnek a PCR vizsgálatokban nyújtott segítségéért. Köszönöm az SZTE Növénybiológiai Tanszék munkatársainak, Laskay Gábornak, az angol nyelvü közleményeim lektorálását, külön szeretném megköszönni Kolbert Zsuzsannának baráti és technikai támogatását. Hálás köszönettel tartozom Légrádi Máriának a reciprok keresztezések kivitelezésében nyújtott kiváló asszisztenciáért. Szeretném megköszönni Mihalik Erzsébetnek a SEM vizsgálatokban nyújtott segítségét.

Köszönetet szeretnék mondani Barátaimnak, akik fáradhatatlanul ösztönzöztek, támogattak és kitartottak mellettem az évek során. Köszönöm Jávorfi Tamásnak a szeretetét, bíztatását, ezen kívül a dolgozatom elkészítésében nyújtott technikai segítséget és az angol nyelvü közlemények lektorálását. Végül, de nem utolsó sorban köszönöm Édesanyámank hogy éveken keresztül támogatott és segítette munkámat és doktori disszertációm elkészülését. 